\author{
UNIVERSIDADE DE SÃO PAULO \\ ESCOLA DE ENGENHARIA DE SÃO CARLOS \\ PROGRAMA DE PÓS-GRADUAÇÃO EM GEOTECNIA
}

MONIQUE DE PAULA NEVES

ANÁLISE DOS PROCESSOS EROSIVOS NA BACIA DO CÓRREGO
DO MEIO - MUNICÍPIO DE SÃO PEDRO (SP): ESTUDO DO
DESENCADEAMENTO DAS EROSÕES

São Carlos

2017 
MONIQUE DE PAULA NEVES

\section{ANÁLISE DOS PROCESSOS EROSIVOS NA BACIA DO CÓRREGO DO MEIO - MUNICÍPIO DE SÃO PEDRO (SP): ESTUDO DO DESENCADEAMENTO DAS EROSÕES}

Dissertação apresentada à Escola de Engenharia de São Carlos - Universidade de São Paulo, como parte dos requisitos para obtenção do título de Mestre em Ciências, Programa de Pós-Graduação em Geotecnia.

Orientador: Prof. Dr. Osni José Pejon

VERSÃO CORRIGIDA

São Carlos

2017 
Autorizo a reprodução e divulgação total ou parcial deste trabalho, por qualquer meio convencional ou eletrônico, para fins de estudo e pesquisa, desde que citada a fonte.

Ficha catalográfica preparada pela Seção de Tratamento da Informação do Serviço de Biblioteca - EESC/USP

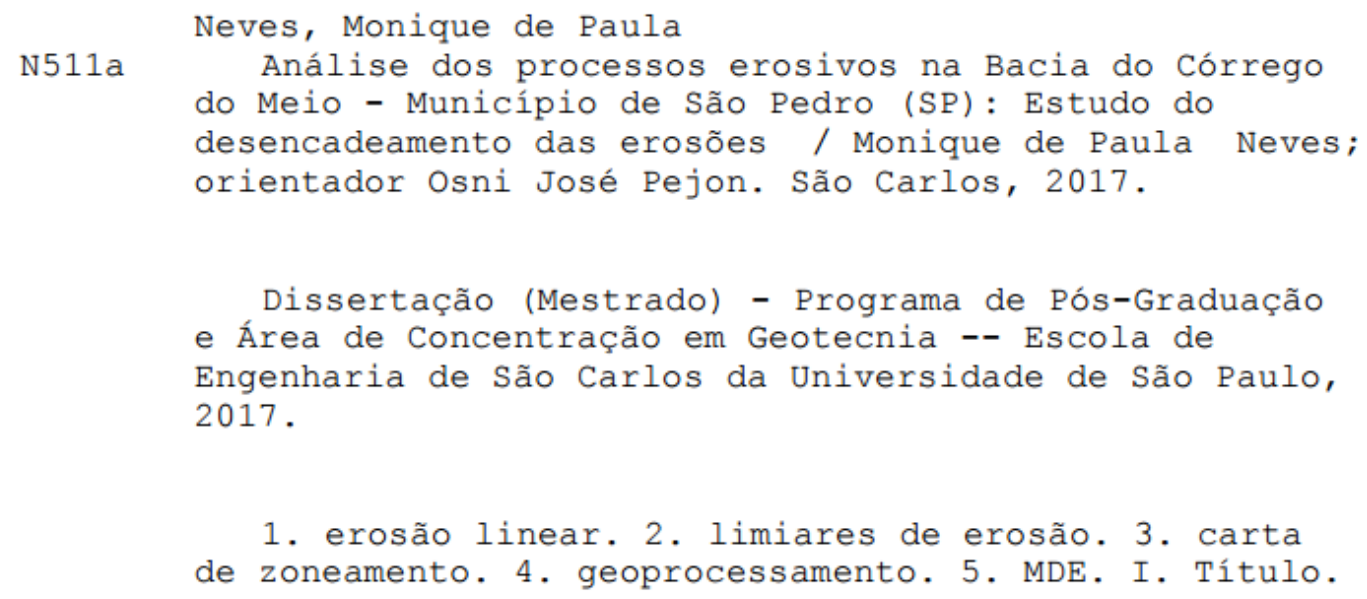




\section{FOLHA DE JULGAMENTO}

Candidata: Bacharela MONIQUE DE PAULA NEVES.

Título da dissertação: "Análise dos processos erosivos na Bacia do Córrego do Meio - município de São Pedro (SP): estudo do desencadeamento das erosões".

Data da defesa: $27 / 04 / 2017$.

\section{Comissão Julgadora:}

Prof. Titular Osni José Pejon

(Orientador)

(Escola de Engenharia de São Carlos/EESC)

Prof. Dr. Reinaldo Lorandi

(Universidade Federal de São Carlos/UFSCar)

Prof. Dr. José Augusto de Lollo

(Universidade Estadual Paulista "Júlio de Mesquita Filho/UNESP-IIha Solteira)
Resultado:
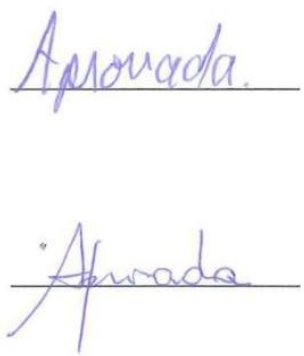

Coordenador do Programa de Pós-Graduação em Geotecnia:

Prof. Dr. Edmundo Rogério Esquivel

Presidente da Comissão de Pós-Graduação:

Prof. Associado Luis Fernando Costa Alberto 


\section{Agradecimentos}

A Deus, por sempre cuidar de mim com amor tão terno e fiel!

Ao professor Osni Pejon pela caminhada que percorremos juntos. Obrigada pela paciência, amizade e incentivo!

Ao professor David Tarboton por ser sempre solicito e esclarecer todas as dúvidas técnicas!

Ao professor Lázaro Zuquette pela contribuição e amizade!

À professora Valéria Guimarães pela oportunidade da monitoria, e sobretudo pelo carinho e atenção!

Aos professores Eduardo Collares e Ana Carina Collares pela amizade, e estímulo desde a graduação!

Em especial a minha mãe Helenice por ser meu porto seguro! Ao meu pai Cristian e minha irmã Rebeca por serem meus grandes incentivadores! Aos meus avós pelo carinho incomparável, que enriquece meu coração! A todos os tios e tias, primos e primas, obrigada pelo apoio incondicional! Vocês sempre serão a minha base!

Ao meu namorado, amigo e companheiro Gabriel, obrigada por tudo, e principalmente por tornar meus dias mais especiais!

Aos meus amigos queridos, Ana Flávia, Carol, Fernando, Larissa, Lucas e Rhuan por estarem sempre perto, apesar da distância!

Aos amigos de São Carlos, especialmente Yara, Cahio Eiras e Denis Watashi pela parceria em todos os momentos!

A Dagui pelas palavras amigas, na reta final!

A galera do "Map World" por acompanharem os bastidores! Obrigada pelos momentos de descontração, bolachas e cafés... Moisés Failache "thank you” pelas dicas musicais!

Aos colegas do Departamento de Geotecnia pela convivência durante este período!

A todos os técnicos e funcionários do Departamento de Geotecnia pela disposição em ajudar! Ao CNPq pela concessão da bolsa de mestrado! 
"Tudo é possível àquele que crê" Mc 9,23 


\section{RESUMO}

NEVES, M. P. Análise dos processos erosivos na Bacia do Córrego do Meio - Município de São Pedro - SP: Estudo do desencadeamento das erosões. 2017. 179 f. Dissertação. Escola de Engenharia de São Carlos, Universidade de São Paulo, São Carlos, 2017.

No âmbito da geomorfologia pressupõe-se que existe uma relação entre declividade (S) e área de contribuição (A) que condiciona o escoamento superficial necessário para ocasionar o surgimento das erosões. A relação entre estes parâmetros pode ser expressa pelo índice $\mathrm{S}=a \mathrm{~A}^{-b}$, que representa o limiar crítico de desencadeamento das erosões. Implementando este índice no SIG, pode-se elaborar produtos cartográficos com a finalidade de reproduzir espacialmente as áreas críticas sujeitas a ocorrência das erosões. O presente trabalho teve por objetivo realizar um estudo sobre o desencadeamento das erosões lineares, utilizando técnicas de geoprocessamento para obtenção dos parâmetros A e S. A área em estudo compreende a Bacia do Córrego do Meio, localizada no município de São Pedro - SP, e apresenta uma área de 48,06 $\mathrm{km}^{2}$. Os pontos de feições erosivas foram compilados de trabalhos realizados previamente na área, e também por meio do levantamento em imagens de satélites e ortofotos, totalizando 58 pontos de erosões. O modelo digital de elevação (MDE), mapa de área de contribuição e declividade foram elaborados em ambiente SIG, com diferentes pixels de saída, 2, 10 e 30 metros, e para processamento dos dados hidrológicos foram utilizados dois algoritmos: D8 e D-Infinity. Os parâmetros A e S foram calculados para cada uma das feições, analisadas de maneira integrada, e com base em características especificas como posição no relevo e profundidade dos canais. O tamanho do pixel de saída refletiu significativamente na obtenção dos parâmetros A e S, por isso, foram utilizados os modelos com resoluções maiores, pois corresponderam melhor às características da área. Em relação aos algoritmos de fluxo acumulado o D-Infinity apresentou dados mais condizentes com a topografia, e possibilitou o ajuste matemático do limiar crítico no gráfico $\mathrm{S} x \mathrm{~A}$. O índice obtido a partir da análise integrada foi $S=0,060 \mathrm{~A}^{-0,280}$, o índice para feições localizadas em

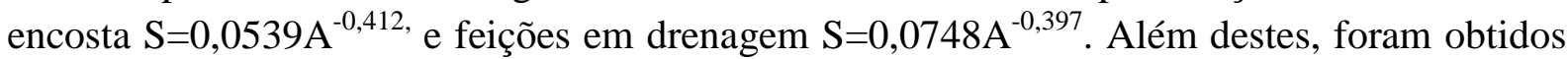
outros índices específicos, determinados conforme a profundidade das feições $(<0,5 ; 0,5$ a 1 ; 1 a 1,5 e >1,5m). A implementação dos índices no SIG possibilitou a elaboração das Cartas de Zoneamento de Áreas de Ocorrência de Erosão que apresentaram resultados consistentes, quando comparadas com outros produtos cartográficos, e podem orientar a ocupação adequada nestes locais, evitando a deflagração de novos processos. Apesar de ser um modelo de predição de erosão simples, os dados obtidos auxiliaram a compreensão dos mecanismos de desencadeamento, por isso, podem subsidiar as ações de planejamento ambiental, visando à recuperação das áreas comprometidas, com o intuito de minimizar os danos ambientais, e as perdas econômicas e sociais.

Palavras-chave: erosão linear; limiares de erosão; carta de zoneamento; geoprocessamento; MDE. 


\begin{abstract}
NEVES, M. P. Analysis of the erosive processes at Córrego do Meio Wastershed Municipality of São Pedro - SP: study of erosion initiation. 2017. 179 f. Dissertação. Escola de Engenharia de São Carlos, Universidade de São Paulo, São Carlos, 2017.

Considering the geomorphology aspects, it is assumed that there is a relationship between slope (S) and contributing area (A) which determines the runoff necessary for the onset of erosion. The relationship between the morphometric parameters can be expressed by the index $\mathrm{S}=a \mathrm{~A}^{-b}$ which represents the topographic threshold for the onset of erosion. Implementing this index in the GIS, cartographic products can be performed with the purpose of reproducing spatially the critical areas subject to the erosion occurrence. The aim of this work is the study if the onset of gully erosions using geoprocessing techniques to obtain the parameters $\mathrm{A}$ and S. The study area is the watershed of the Córrego do Meio, located in São Pedro, São Paulo state, with an approximated area of $48.06 \mathrm{~km}^{2}$. The erosion feature was compiled from previous study in the area and also through the survey on satellite images and orthophotographs, totalizing 58 erosion points. The digital elevation model (DEM), contribution area and slope were performed in GIS, with different output pixels, 2, 10 and 30 meters, and for the hydrological data processing, two algorithms were used: D8 and DInfinity. The parameters $A$ and $S$ were calculated for each of the erosion feature, which were analyzed as a whole, and also based on the specific characteristics such as position in the landforms and depth of the channels. The size of the output pixel reflected significantly in obtaining the parameters $\mathrm{A}$ and $\mathrm{S}$, therefore, models with higher resolutions were used because they better represent the characteristics of the area. In relation to the flow accumulation algorithms, D-Infinity presented more consistent data with the topography, and enabled the mathematical adjustment of the threshold in the SxA chart. The index obtained from the analysis of all erosion was $\mathrm{S}=0.060 \mathrm{~A}^{-0.280}$, the index for erosions located in hillside $\mathrm{S}=0.0539 \mathrm{~A}^{-0.412}$, and erosions in drainage $\mathrm{S}=0.0748 \mathrm{~A}^{-0.397}$. Besides these, other specific indices were determined, according to the depth of the channels $(<0.5,0.5$ to 1,1 to 1.5 and $>$ $1.5 \mathrm{~m})$. The implementation of the indexes in the GIS made possible to perform the Zoning Map of Probable Erosion Areas, which showed consistent results when compared to other cartographic products and may direct suitable occupancy in these locations, so as to avoid the onset of new processes. Although it is a model for prediction of simple erosion, the obtained data helped to understand the mechanisms of the onset of the gully erosion, and therefore, can subsidize the actions of environmental planning, aiming at the recovery of the committed areas, with the aim of minimizing environmental damage and economic and social losses.
\end{abstract}

Keywords: gully erosion, threshold of erosion, zoning map, geoprocessing, DEM. 


\section{Lista de Figuras}

Figura 1 - Fatores que contribuem para ocorrência dos processos erosivos. 27

Figura 2 - Velocidade crítica da água necessária para que ocorra erosão, transporte e deposição, em função do tamanho das partículas .29

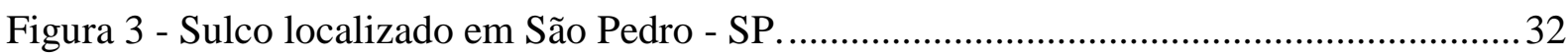

Figura 4 - Ravina localizada em São Pedro - SP................................................................ 33

Figura 5 - Voçoroca localizada em São Pedro - SP............................................................... 34

Figura 6 - Classificação das encostas proposta por Ruhe (1975) ........................................... 38

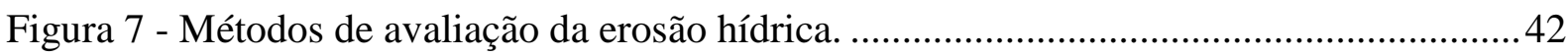

Figura 8 - Gráfico SxA para erosões laminares (Colorado). .................................................. 45

Figura 9 - Limiares topográficos conforme os processos dominantes (Mar Mediterrâneo). ... 47

Figura 10 - Gráfico SxA para canais localizados na Bélgica. ............................................... 48

Figura 11 - Mapa de áreas críticas (Sudoeste Espanha).......................................................49

Figura 12 - Gráficos SxA para diferentes método de obtenção dos parâmetros. ..................... 50

Figura 13 - Gráfico SxA para canais localizados na região de São Pedro - SP. ......................51

Figura 14 - Gráfico SxA para canais localizados em Piratinga - SP. ......................................52

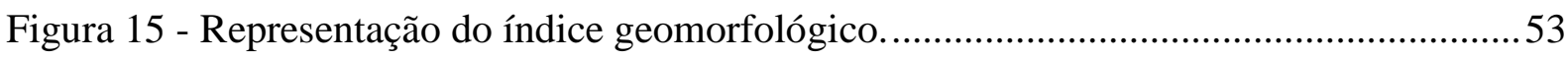

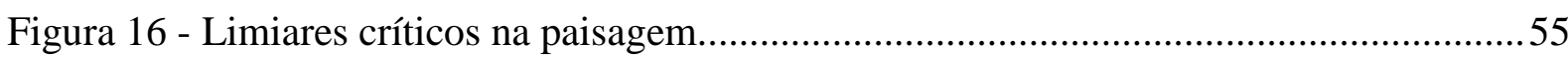

Figura 17 - Limiares de saturação do solo, de erosão por escoamento superficial, e

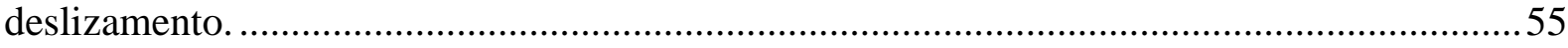

Figura 18 - Documentos cartográficos produzidos pelo mapeamento geotécnico...................58

Figura 19 - Atributos do meio físico associados à erosão. .....................................................59

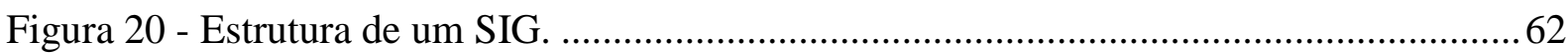

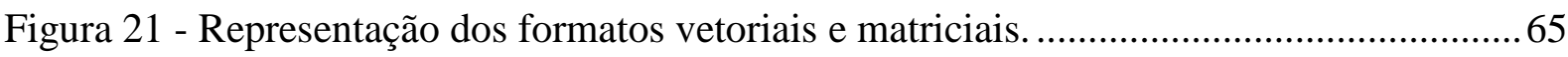

Figura 22 - Processamento para obtenção do MDE. ………..................................................66

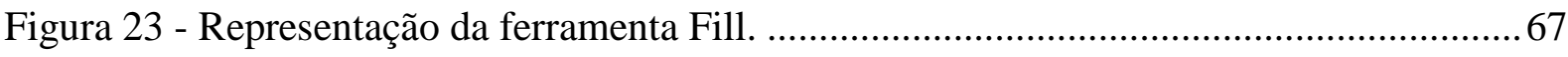

Figura 24 - Direção de fluxo pelo método D8 ........................................................................ 70

Figura 25 - Direção de fluxo pelo método D-Infinity. ............................................................ 71

Figura 26 - Mapa de influência para os diferentes métodos................................................... 71

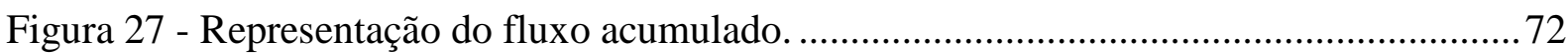

Figura 28 - Etapas para elaboração do mapa de área de contribuição no TauDEM................. 73

Figura 29 - Etapas para elaboração do mapa de área de contribuição no ArcGIS. .................. 74 


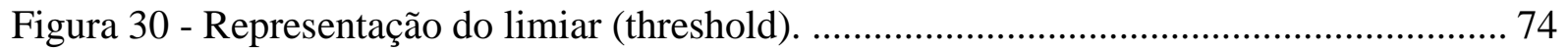

Figura 31 - Etapas para obtenção dos aspectos hidrológicos. .............................................. 75

Figura 32 - Mapa de localização da Bacia Hidrográfica do Córrego do Meio. ........................ 77

Figura 33 - Distribuição das chuvas na região de São Pedro.................................................. 78

Figura 34 - Mapa de uso e ocupação da terra (2013) da Bacia do Córrego do Meio. ............. 82

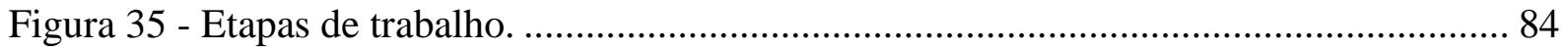

Figura 36 - Mosaico das cartas topográficas da área em estudo............................................. 86

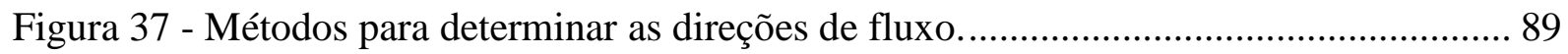

Figura 38 - Etapas para elaboração do mapa de área de contribuição. .................................... 89

Figura 39 - Representação da ferramenta “D-Infinity Upslope Dependence”........................ 90

Figura 40 - Exemplo de ajuste do limiar topográfico. ........................................................ 91

Figura 41 - Processamento para elaboração da carta de zoneamento. ..................................... 92

Figura 42 - Mapa de documentação da Bacia do Córrego do Meio. ........................................ 97

Figura 43 - Percentual de ocorrência das unidades de landforms......................................... 102

Figura 44 - Mapa de Landforms da Bacia do Córrego do Meio. .............................................. 103

Figura 45 - Mapa de Substrato Rochoso da Bacia do Córrego do Meio. ............................... 105

Figura 46 - Percentual de ocorrência das unidades de materiais inconsolidados. .................. 106

Figura 47 - Mapa de materiais inconsolidados da Bacia do Córrego do Meio....................... 107

Figura 48 - Modelos Digitais de Elevação (MDE). ............................................................. 112

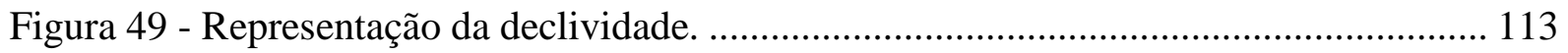

Figura 50 - Percentual de ocorrência das classes de declividades. ........................................ 113

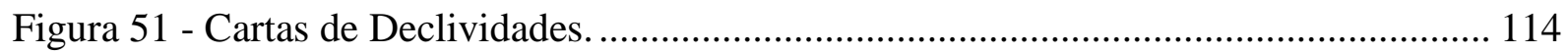

Figura 52 - Variabilidade espacial das classes de declividade.............................................. 115

Figura 53 - Valores máximo de fluxo acumulado para a Bacia do Córrego do Meio em função

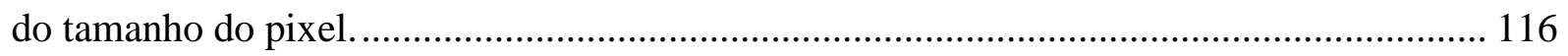

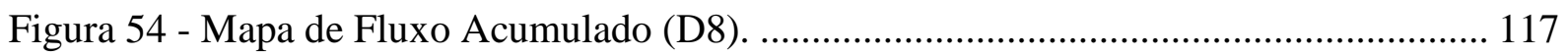

Figura 55 - Mapa de Fluxo Acumulado (D-Infinity). .......................................................... 118

Figura 56 - Mapas de fluxo acumulado e feições erosivas. ..................................................... 119

Figura 57 - Áreas de contribuição determinadas pelo D-Infinity com pixels de diferentes tamanhos.

Figura 58 - Gráfico SxA para os dados processados com pixels de diferentes tamanhos. .... 121

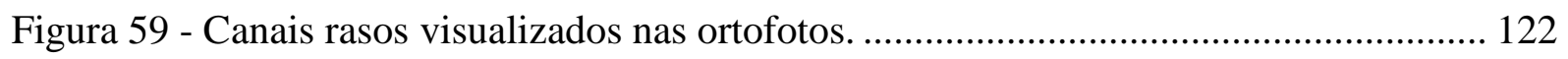

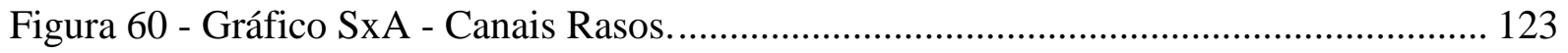

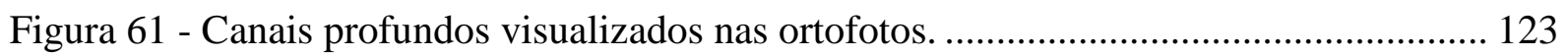


Figura 62 - Gráfico SxA - Canais profundos

Figura 63 - Áreas de contribuição processadas automaticamente com os algoritmos D8 e DInfinity. 125

Figura 64 - Critérios para classificação das feições.

Figura 65 - Gráfico SxA das feições localizadas em encosta................................................ 128

Figura 66 - Gráfico SxA das feições localizadas em drenagem.

Figura 67 - Localização das feições na região da Serra de Itaqueri.

Figura 68 - Perfil topográfico das encostas localizadas na Serra de Itaqueri.

Figura 69 - Gráfico SxA - Bacia do Córrego do Meio.

Figura 70 - Posicionamento do limiar critico no gráfico de Dietrich et al. (1992).

Figura 71 - Níveis de detalhamento para elaboração dos limiares críticos.

Figura 72 - Feições localizadas em encosta.

Figura 73 - Gráfico SxA para as feições localizadas em encosta da Bacia do Córrego do Meio.

Figura 74 - Gráfico SxA para as feições localizadas em encosta conforme a profundidade dos canais.

Figura 75 - Feições localizadas em drenagem.

Figura 76 - Gráfico SxA para as feições localizadas em drenagem da Bacia do Córrego do Meio.

Figura 77 - Gráfico SxA para as feições localizadas em drenagem conforme a profundidade dos canais. 138

Figura 78 - Representação detalhada das áreas críticas. 140

Figura 79 - Carta Geral de Zoneamento de Áreas de Ocorrência de Erosão. 141

Figura 80 - Carta de Zoneamento de Áreas de Ocorrência de Erosões em Encosta. 145

Figura 81 - Carta de Zoneamento de Áreas de Ocorrência de Erosões em Drenagem.

Figura 82 - Percentual de ocorrência das classes de susceptibilidade. 150

Figura 83 - Carta de Susceptibilidade à Erosão de Gomes (2002). 151

Figura 84 - Processo erosivo localizado em área de chacreamento. 152

Figura 85 - Percentual de áreas de ocorrência de erosões coincidentes com as classes de susceptibilidade.

Figura 86 - Carta de zoneamento de áreas de ocorrência de erosões sobreposta às classes de susceptibilidade.

Figura 87 - Percentual de áreas de ocorrência de erosões em encosta coincidentes com as classes de susceptibilidade. 
Figura 88 - Carta de zoneamento de áreas de ocorrência de erosões em encosta sobreposta às classes de susceptibilidade.

Figura 89 - Percentual de áreas de ocorrência de erosões em drenagem coincidentes com as classes de susceptibilidade.

Figura 90 - Carta de zoneamento de áreas de ocorrência de erosões em drenagem sobreposta às classes de susceptibilidade. 


\section{LisTa de TABelas}

Tabela 1 - Tipos de erosão e agentes causadores. 27

Tabela 2 - Processos envolvidos na formação das erosões. 30

Tabela 3 - Características das feições erosivas. 35

Tabela 4 - Características dos solos que interferem nos processos erosivos. 39

Tabela 5 - Exemplos de ensaios para avaliação da erodibilidade dos solos. 40

Tabela 6 - Agentes deflagradores dos processos erosivos. 41

Tabela 7 - Modelos de avaliação quantitativa indireta das erosões. 43

Tabela 8 - Métodos e fontes de informação utilizadas 45

Tabela 9 - Autores, locais e coeficientes a e -b. 46

Tabela 10 - Softwares de geoprocessamento 61

Tabela 11 - Softwares livres análise hidrológica. 68

Tabela 12 - Algoritmos utilizados nas análises hidrológicas. 69

Tabela 13 - Características litoestratigráficas das formações presentes na área em estudo. ....79 Tabela 14 - Dados referentes às principais unidades de materiais inconsolidados da região em estudo.

Tabela 15 - Área e percentual das classes do uso e cobertura do solo. 81

Tabela 16 - Materiais e softwares utilizados na pesquisa. 83

Tabela 17 - Estrutura do banco de dados da Bacia do Córrego do Meio. 85

Tabela 18 - Característica das ortofotos. 87

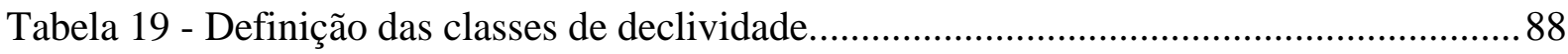

Tabela 20 - Pontos de feições erosivas da Bacia do Córrego do Meio . ................................... 99

Tabela 21 - Características dos sistemas e unidades de landforms. 101

Tabela 22 - Dados referentes aos materiais inconsolidados presentes na Bacia do Córrego do Meio.

Tabela 23 - Número de colunas e linhas dos modelos digitais de elevação. 111

Tabela 24 - Índices SxA para a Sub-bacia dos Córregos dos Alpes e Retiro. 125

Tabela 25 - Valores do coeficiente de determinação $\left(\mathrm{r}^{2}\right)$ para diferentes análises, utilizando o

D-Infinity. 129

Tabela 26 - Índices SxA para a Bacia do Córrego do Meio. 139

Tabela 27 - Classes de susceptibilidade definidas por Gomes (2002). 


\section{Lista de Siglas}

\begin{tabular}{ll} 
A & Área de Contribuição \\
ABNT & Associação Brasileira de Normas Técnicas \\
Acb & Índice de atividade da fração fina \\
CEPAGRI & Centro de Pesquisas Meteorológicas e Climáticas Aplicadas à Agricultura \\
CTC & Capacidade de Troca Catiônica \\
DAEE & Departamento de Águas e Energia Elétrica \\
E & Índice de Erodibilidade \\
EUPS & Equação Universal de Perda dos Solos \\
IBGE & Instituto Brasileiro de Geografia e Estatística \\
IDHM & Índice de Desenvolvimento Humano Municipal \\
IG & Instituto Geológico \\
IGC & Instituto Geográfico e Cartográfico \\
IPT & Instituto de Pesquisas Tecnológicas \\
MDE & Modelo Digital de Elevação \\
P & Perda de peso por imersão \\
PIB & Produto Interno Bruto \\
PMSP & Prefeitura Municipal de São Pedro \\
R 2 & Coeficiente de determinação \\
$S$ & Índice de absorção d'água \\
S & Declividade média \\
SE & Superfície Específica \\
SIG & Sistema de Informação Geográfica \\
UGRHI & Unidade de Gerenciamento de Recursos Hídricos \\
UTM & Universal Transverse Mercator \\
VB & Volume de azul de metileno \\
\hline
\end{tabular}




\section{SUMÁRIO}

1. INTRODUÇÃ $\mathrm{O}$..................................................................................................................................... 19

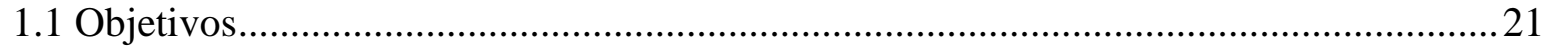

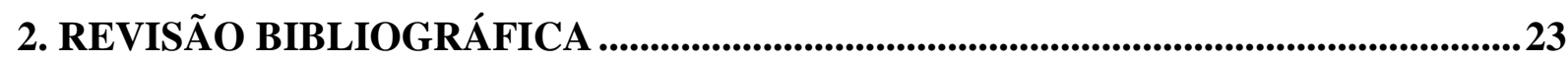

2.1 Bacia hidrográfica como unidade de planejamento...............................................23

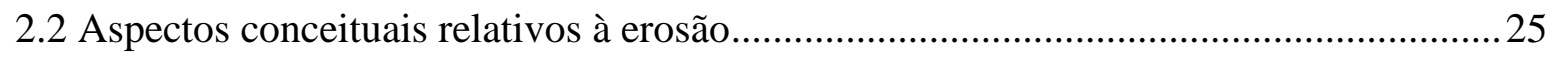

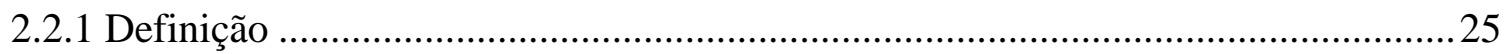

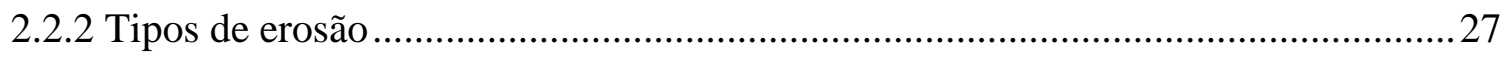

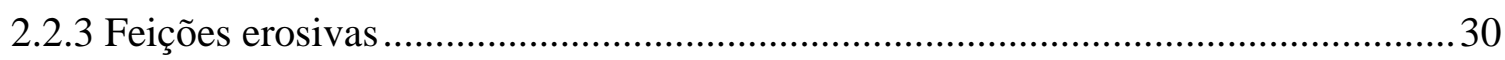

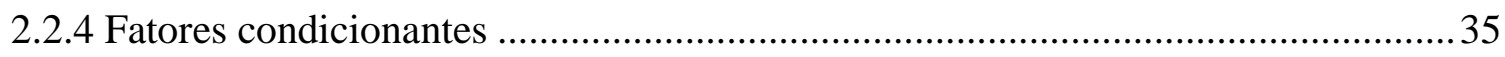

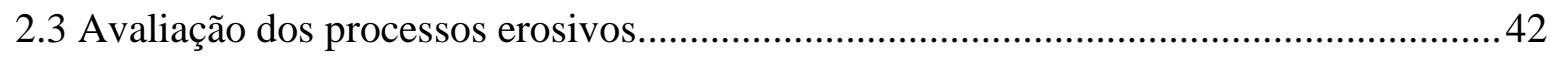

2.3.1 Modelos estatísticos, físicos e paramétricos ............................................................... 42

2.4 Índices que relacionam área de contribuição $x$ declividade .......................................4 44

2.4.1 Limiar para representação das áreas instáveis ...................................................52

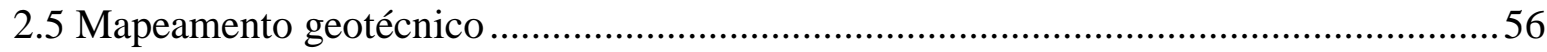

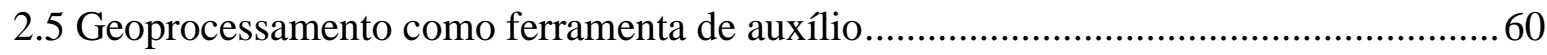

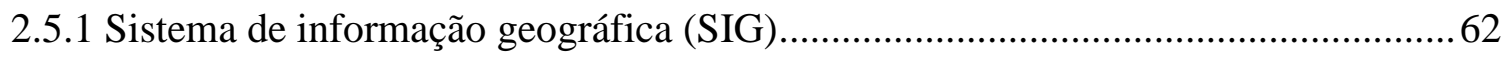

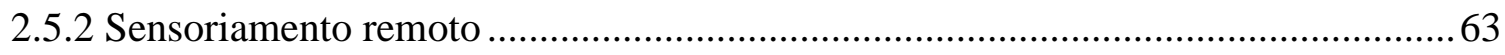

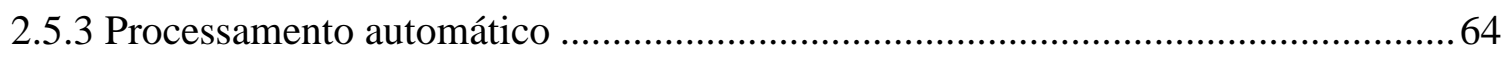

3. CARACTERIZAÇÃo GERAL DA ÁREA DE ESTUDO .............................................. 77

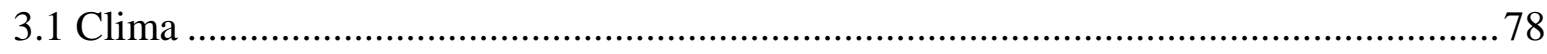

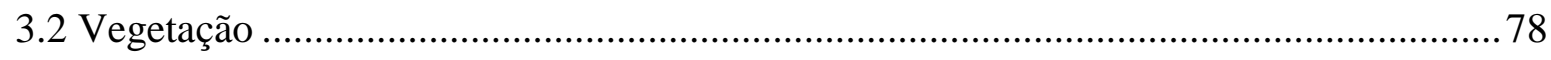

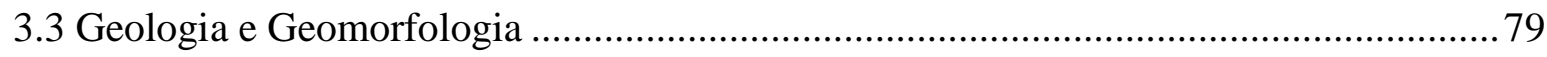

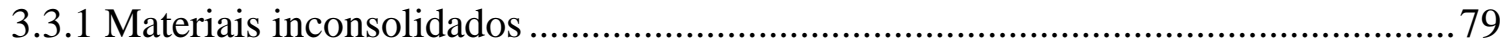

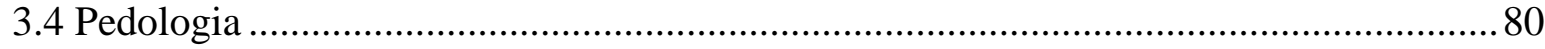

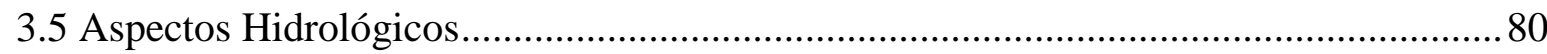




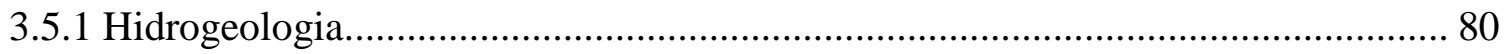

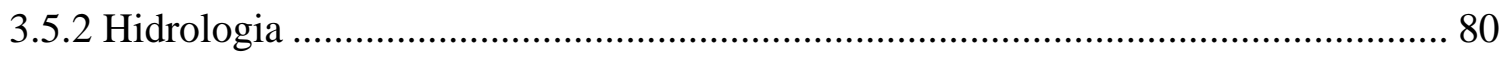

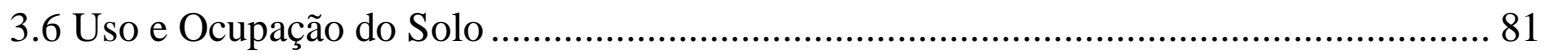

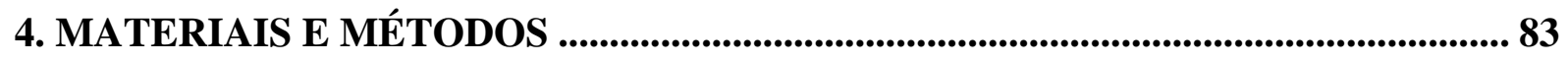

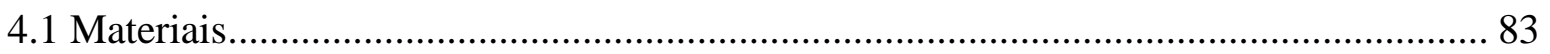

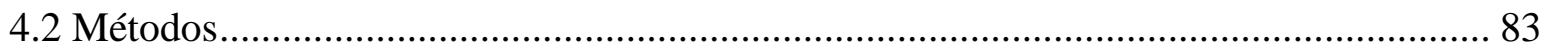

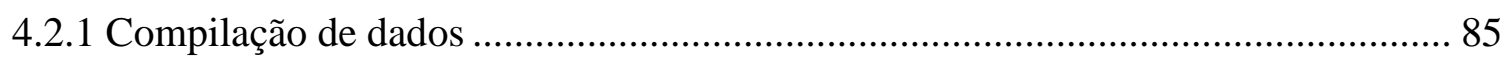

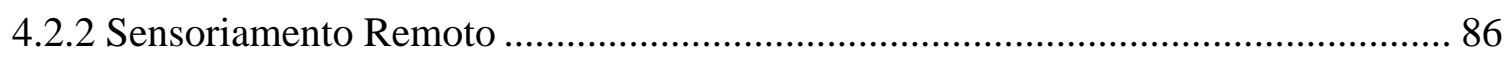

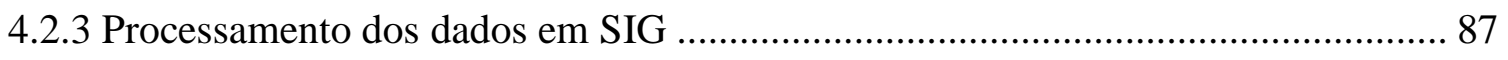

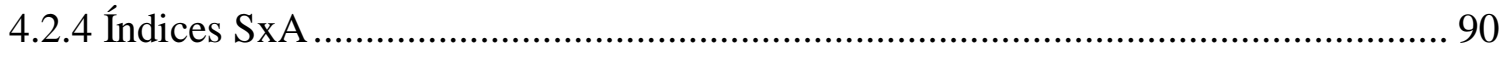

4.2.5 Zoneamento de áreas críticas de processos erosivos ........................................... 92

5. RESULTADOS.................................................................................................................................. 95

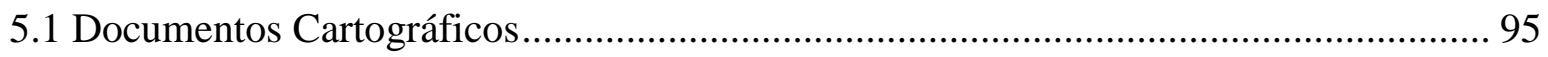

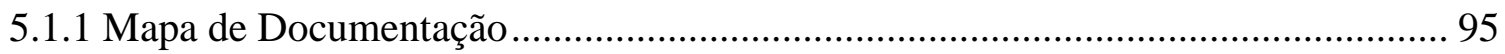

5.1.2 Mapas Geológicos-Geotécnicos................................................................... 100

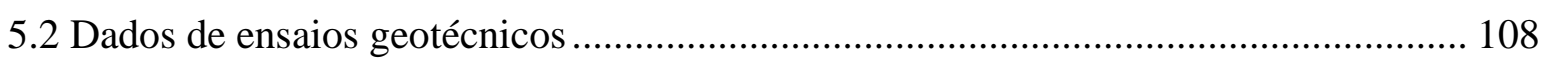

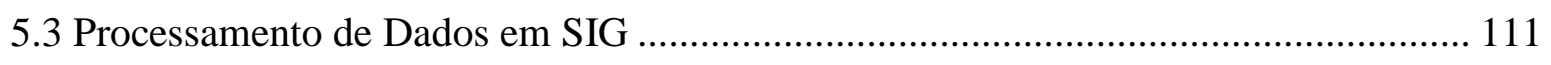

5.3.1 MDE (Modelo Digital de Elevação) ................................................................ 111

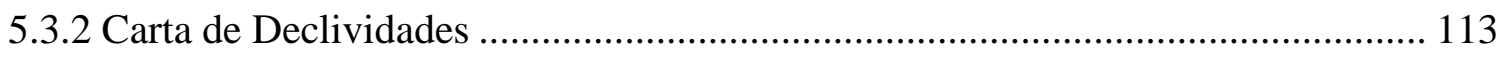

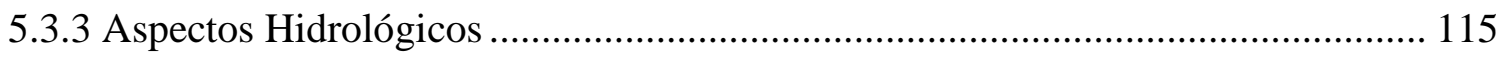

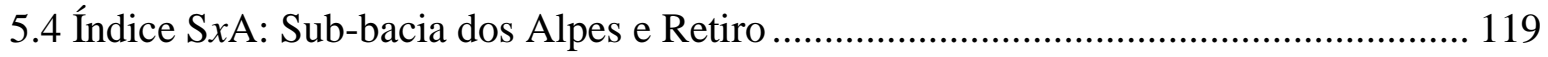

5.4.1 Interferência da resolução espacial na elaboração dos índices ............................ 120

5.4.2 Aplicação do D-Infinity para os índices propostos por Araújo (2011)................. 121

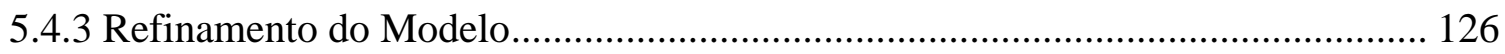

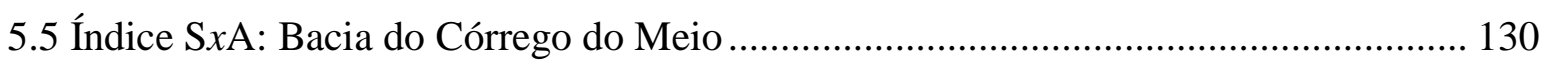

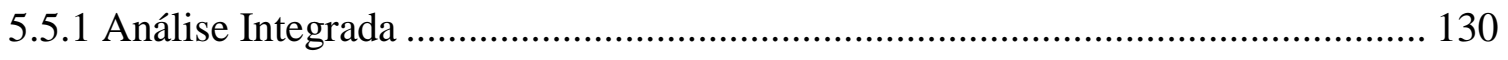

5.5.2 Análise de acordo com a classificação das feições ............................................. 134 
5.6 Zoneamento de Áreas de Ocorrência de Erosões com base nos limiares topográficos 139

5.6.1 Geral

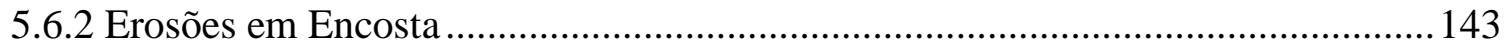

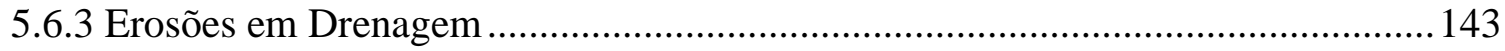

5.6.4 Comparação das Cartas de Zoneamento com a Carta de Susceptibilidade ............ 149

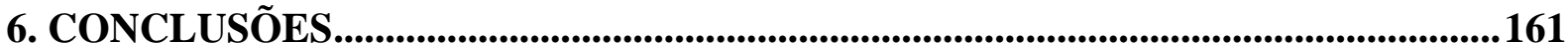

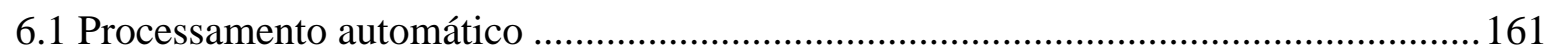

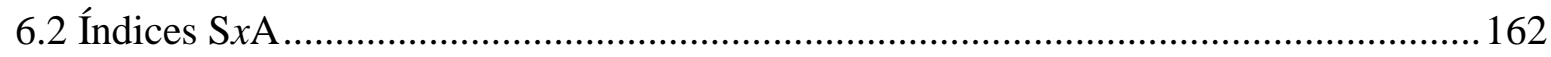

6.3 Cartas de Zoneamento de Áreas de Ocorrência de Erosões ........................................ 163

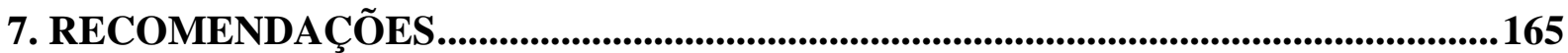

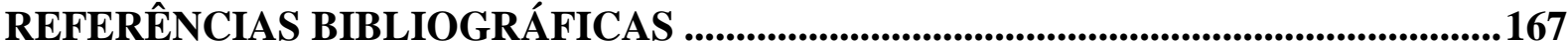

ANEXO A 



\section{INTRODUÇão}

Os processos erosivos podem ocorrer de maneira natural ou acelerada, na primeira condição se caracterizam como um processo lento, de remodelação do relevo, onde as taxas de erosão e perda de sedimentos estão inseridas em uma dinâmica natural da superfície terrestre. Por outro lado, a erosão acelerada é decorrente das intervenções antrópicas e ocorrem em taxas superiores à erosão natural, ocasionando consequentemente a degradação ambiental, que resulta em perdas ambientais, econômicas e sociais (ROTTA; ZUQUETTE, 2015).

As principais consequências causadas pela erosão são alteração na morfometria do relevo; rebaixamento do nível d'água; remoção das camadas superficiais de solo; assoreamento de cursos d'água; remoção dos nutrientes do solo; redução da produção agrícola. Em áreas urbanas podem atingir obras residenciais e de infraestrutura, como estradas, pontes, aterros, tubulações, taludes artificiais e outros (BERTONI; LOMBARDI NETO, 1990; GUERRA, 1998; ROTTA; ZUQUETTE, 2015).

O surgimento das feições erosivas depende de alguns fatores naturais como clima (chuva), geomorfologia, tipo de solo, substrato rochoso e cobertura vegetal. Considerando apenas os aspectos geomorfológicos pressupõe-se que existe uma relação entre declividade (S) e área de contribuição (A), que condiciona o escoamento superficial necessário para dar início à erosão (PATTON; SCHUMM, 1975). A partir da relação proposta pelos autores citados, Begim e Schumm (1979) e Montgomery e Dietrich (1994) definiram uma equação para representar o limiar crítico de desencadeamento das erosões: $\mathrm{S}=a \mathrm{~A}^{-b}$, onde " $a$ " e " $-b$ " são coeficientes que dependem das características do ambiente.

Outra maneira de estudar os processos erosivos é através da elaboração de mapas e cartas geotécnicos, a partir da análise de atributos do meio físico, como geologia, hidrogeologia, hidrologia, entre outros, com a finalidade de avaliar as limitações e potencialidades de uma determinada área. Entre as cartas geotécnicas aplicadas a erosão citam-se: carta de potencial à erosão laminar; carta de susceptibilidade; carta de erodibilidade; carta de risco potencial à erosão acelerada; entre outras. As cartas de susceptibilidade, por exemplo, podem ser elaboradas através do agrupamento hierárquico dos atributos do meio físico, como materiais inconsolidados, substrato rochoso, landforms e declividade. 
Ao aplicar a equação que representa o limiar crítico de desencadeamento das erosões $\left(\mathrm{S}=a \mathrm{~A}^{-b}\right)$, no SIG (Sistema de Informação Geográfica) pode-se elaborar um outro tipo de produto cartográfico, que consiste na representação espacial das áreas críticas onde é possível ocorrer a formação de canais de erosão. Desta maneira, podem ser elaboradas cartas de zoneamento que indiquem as áreas críticas e estáveis em uma encosta, e assim orientar a tomada de decisão do gestor público, no sentido de impedir a degradação e minimizar os danos aos recursos naturais e ao meio ambiente.

Diante deste cenário, o presente trabalho apresenta um estudo sobre o desencadeamento das erosões lineares da Bacia do Córrego do Meio, localizada no município de São Pedro SP. Para desenvolvimento do estudo, considerou-se o método de Patton e Schumm (1975), que estabelece a relação inversa entre área de contribuição (A) e declividade (S), e a aplicação de técnicas de geoprocessamento para obtenção destes parâmetros e elaboração das cartas de zoneamento em ambiente SIG.

Diversos estudos foram realizados considerando a abordagem destes autores, como Vandaele et al. (1996); Vanwalleghem et al. (2005); e Menéndez-Duarte et al. (2007), Gutiérrez et al. (2009); Araújo (2011) e Stabile (2013). Entretanto, poucos foram aplicados em áreas tropicais, com exceção dos dois últimos, desenvolvidos no Brasil, isto enfatiza a importância deste trabalho, visto a necessidade de determinar limiares críticos de desencadeamento das feições considerando as condições geomorfológicas dos países tropicais.

A seleção da Bacia do Córrego do Meio se deve aos diversos estudos já desenvolvidos na área ou no seu entorno, como: Pejon (1992); Gomes (2002); Silva (2003); Dantas-Ferreira (2008); Guimarães (2008); Araújo (2011), entre outros, que constataram a alta incidência de feições erosiva na área, com base na elaboração de mapas e cartas, e análise geotécnica dos processos erosivos. No entanto, nenhum deles estabeleceu o limiar crítico de desencadeamento das erosões para a área em estudo como um todo.

Desta forma, este trabalho se justifica, pois, pretende-se consolidar os estudos realizados, através da proposição do limiar crítico de desencadeamento das erosões (threshold) e da elaboração das cartas de zoneamento de áreas de ocorrência de erosão, integrando as informações geotécnicas e espaciais existentes, por meio das ferramentas de geoprocessamento. Os resultados obtidos irão indicar as áreas com predisposição para 
ocorrência de erosão, e por isso, poderão orientar as ações em termos de planejamento ambiental na área, evitando os problemas decorrentes da degradação ambiental.

\subsection{Objetivos}

O objetivo geral deste trabalho é realizar um estudo do desencadeamento das erosões lineares na Bacia do Córrego do Meio a partir da relação entre área de contribuição (A) e declividade (S), determinadas com o auxílio do geoprocessamento. São objetivos específicos:

- Avaliar a interferência da resolução espacial do MDE na elaboração dos parâmetros A e $\mathrm{S}$

- Avaliar os diferentes algoritmos de fluxo acumulado: D8 e D-Infinity;

- Propor os índices SxA com base nas características das feições erosivas;

- Representar espacialmente os limiares críticos por meio da carta de zoneamento de áreas prováveis de ocorrência de erosão. 



\section{REVISÃo BibLIOGRÁFICA}

\subsection{Bacia hidrográfica como unidade de planejamento}

A bacia hidrográfica é definida como uma área de drenagem composta por cursos d'água que convergem até um ponto de saída, o exutório. Esta área é limitada por divisores topográficos, que correspondem aos pontos de maior cota do terreno, e, portanto, são denominados divisores de água (JORGE; UEHARA, 1998).

Porto e Porto (2008) consideram a bacia hidrográfica como um sistema integrado, sobre o qual se realizam os balanços de entrada e saída de água, que tem seu início com a entrada da água da chuva e o fim com sua saída no exutório. A relação existente entre os diversos sistemas hídricos origina as bacias e sub-bacias hidrográficas.

É importante ressaltar, que sobre esta área de drenagem, são desenvolvidas diversas atividades antrópicas, que ocasionam diferentes processos de degradação ambiental (CALIJURI; CUNHA; POVINELLI, 2010). Portanto, segundo Yassuda (1993) a gestão dos recursos hídricos deve ser realizada de forma integrada, garantindo a conservação, preservação e recuperação do meio físico, de maneira equilibrada e sustentável.

Ao desenvolver seu trabalho, Yassuda (1993) verificou que muitos países como Alemanha, França, Inglaterra e Portugal, já haviam implementado a gestão integrada, indicando que o gerenciamento da água, como recurso natural renovável, deve ser realizado no âmbito do ciclo hidrológico, considerando a interação entre os meios físico, biótico, social e econômico.

Sobre a experiência na França, Machado (2003) cita que em 1964 foi elaborada a Lei das Águas - Nº6 - 1245, que surgiu em decorrência dos problemas enfrentados pelo país, dentre eles, a redução da qualidade da água. Com a finalidade de solucionar tais problemas, o país adotou a bacia hidrográfica como unidade administrativa dos recursos hídricos, uma vez que se caracteriza como uma área geográfica natural do ciclo hidrológico. Após este marco, diversos países elaboraram programas de gestão de recursos hídricos baseado no modelo francês.

Muitas experiências relacionadas à gestão de bacias hidrográficas aconteceram no Brasil, previamente a elaboração de uma política de recursos hídricos específica. Em 1978 foi 
criado em São Paulo o Comitê Especial de Estudos Integrados de Bacias Hidrográficas; no Espírito Santo em 1980 foi constituído o Consórcio Intermunicipal; em 1988 no Rio Grande do Sul foram criados os Comitês de Bacias e, em 1989 nas bacias dos rios Piracicaba e Capivari foi formado um Consórcio Intermunicipal de Bacias. Neste mesmo período, a Associação Brasileira de Recursos Hídricos (ABRH) realizava uma mobilização para a criação de um sistema organizado de gestão (PORTO; PORTO, 2008).

Neste contexto, em janeiro de 1997 foi sancionada a Lei Federal No 9.433 - Política Nacional dos Recursos Hídricos, que estabeleceu os fundamentos, objetivos, diretrizes e instrumentos para a gestão da água em âmbito nacional. Como um de seus fundamentos a Lei Federal instituiu a "bacia hidrográfica como unidade territorial para implementação da Política Nacional de Recursos Hídricos e atuação do Sistema Nacional de Gerenciamento de Recursos Hidricos" (BRASIL, 1997).

Autores como Silva (2000); Tundisi (2006); Calijuri; Cunha e Povinelli (2010) afirmam que muitos avanços foram alcançados com a aplicação da Política Nacional de Recursos Hídricos, dentre eles, o mais significativo foi à adoção da bacia hidrográfica como unidade físico-territorial de gerenciamento e planejamento. Segundo Calijuri; Cunha e Povinelli (2010), a bacia hidrográfica pode indicar a qualidade ambiental de uma determinada área, permitindo a avaliação de problemas como poluição das águas, assoreamento de cursos d'água e escassez hídrica, e sua adoção como unidade físico-territorial representa um avanço no âmbito da sustentabilidade. Os autores exemplificam citando o programa de gestão de recursos hídricos de Nova York (New York City Watershed Program) que assegura a proteção dos mananciais que abastecem a população, sendo que, além disso, em todo o estado deve ser garantido o monitoramento, avaliação e manejo dos sistemas aquáticos.

Para Tundisi (2006), este avanço representa uma mudança de paradigma no processo de gestão dos recursos hídricos, pois o sistema passou a ser integrado e preditivo, e também se insere no contexto de um ecossistema hidrologicamente interligado, com seus componentes e subsistemas. A gestão por bacias hidrográficas permite obter também progressos tecnológicos, uma vez que favorece a integração do planejamento territorial e uso do solo com a gestão dos recursos hídricos.

Segundo Silva (2000), a adoção da bacia hidrográfica como unidade de gestão contribui para o ordenamento de todas as atividades desenvolvidas, considerando a relação existente 
entre a disponibilidade de água e as necessidades humanas. A gestão da água deve promover a melhoria da qualidade de vida, o aproveitamento e proteção dos recursos hídricos, desta forma, a bacia hidrográfica se caracteriza como unidade física mais apropriada para estudos ambientais.

Neste contexto, verifica-se que o planejamento integrado é peça fundamental para a gestão dos recursos hídricos, pois de acordo com Porto e Porto (2008) é sobre este território que ocorrem quase todas as atividades humanas: ocupação urbana; atividades industriais; uso do solo e também a presença de áreas de preservação, por isso, todas as consequências ambientais geradas são resultantes das formas de ocupação e dos diversos usos dos recursos hídricos.

\subsection{Aspectos conceituais relativos à erosão}

\subsubsection{Definição}

O termo erosão tem sua origem da palavra "erodere" em latim, que significa desgastar. No âmbito geológico, o termo foi utilizado pela primeira vez para delinear alguns processos, como a formação de depressões no terreno devido à ação da água da chuva. A palavra erosão é utilizada para descrever os processos de desagregação de partículas de solo ou rocha, devido à ação de fatores externos, como água, neve, gelo, vento e organismos (ZACHAR, 1982).

De acordo com Lal (1994), a palavra erosão denota os processos que envolvem o desgaste da paisagem, especificamente a remoção e arraste das partículas do solo, seguida pela deposição deste material.

Vilar e Prandi (1993) definem a erosão como os diversos processos que ocasionam a desagregação, desgaste e transporte dos materiais presentes na crosta terrestre, devido à ação das geleiras, rios, mares, ventos ou chuva. Estes processos ocorrem naturalmente, de maneira lenta e contínua, conforme o desenvolvimento da paisagem. No entanto, a interferência antrópica pode intensificá-los, originando processos mais complexos.

Em relação às etapas do processo erosivo, para Guerra (1998) a primeira delas consiste na remoção, seguida pelo transporte do material removido, e por fim, quando não existe mais energia para dar continuidade no processo, ocorre a deposição. $\mathrm{O}$ autor ressalta que, todo este 
processo só ocorre quando as forças atuantes, ou seja, aquelas com capacidade de remover e transportar as partículas de solo ou rocha for maior que a sua capacidade de resistência.

Desta forma, os processos erosivos podem ocorrer com ou sem a influência humana, ocasionando dois tipos de erosão, geológica e acelerada (LAL, 1994). De acordo com Salomão e Iwasa (1995) o processo da erosão natural ou geológica, se desenvolve com a mesma intensidade da formação do solo, ou seja, em condições de equilíbrio. A erosão acelerada ou antrópica por sua vez, ocorre com intensidades superiores, o que não favorece a recuperação natural do local.

A erosão é classificada como natural quando ocorre lentamente ao longo do tempo geológico em um ambiente controlado apenas por fatores naturais. Quando este tipo de erosão sofre interferência devido às mudanças climáticas ou geológicas, modificando a velocidade e a intensidade do processo, consiste em um processo de erosão acelerada, onde a remoção do material inconsolidado torna-se mais rápida do que sua reposição pelos processos de intemperismo das rochas. O processo é lento quando comparado com processos acelerados pela ação do homem e, se torna perceptível, em milhares de anos (PEJON, 1992).

Para o referido autor, a erosão antrópica ocorre quando o homem interfere no ambiente natural acelerando os processos erosivos, por isso é considerada como erosão acelerada. Este tipo de processo é muito mais rápido que a erosão natural e pode evoluir em poucos anos, atingindo extensas áreas.

Segundo Vilar e Prandi (1993) as partículas de solo erodidas, que foram desagregadas e transportadas, podem se depositar em diversos lugares, ocasionando assoreamento de cursos d'água e reservatórios. Para os autores a erosão acelerada ocasiona várias consequências no ambiente como redução de áreas agrícolas; degradação e contaminação de cursos d'água; perdas de bens públicos; prejuízos sociais e econômicos.

De acordo com Barrow (1991), a ocorrência dos processos erosivos está condicionada por alguns fatores como: erosividade, erodibilidade, proteção do solo e manejo do terreno (Figura 1). A erosividade corresponde à capacidade que a chuva possui de causar erosão e, é determinada em função da intensidade e duração dos eventos. A erodibilidade consiste na vulnerabilidade do solo à ocorrência de processos erosivos em decorrência de suas propriedades. A proteção do solo é proporcionada pela presença de vegetação, e o manejo está relacionado com as formas de uso do terreno. 
Figura 1 - Fatores que contribuem para ocorrência dos processos erosivos.

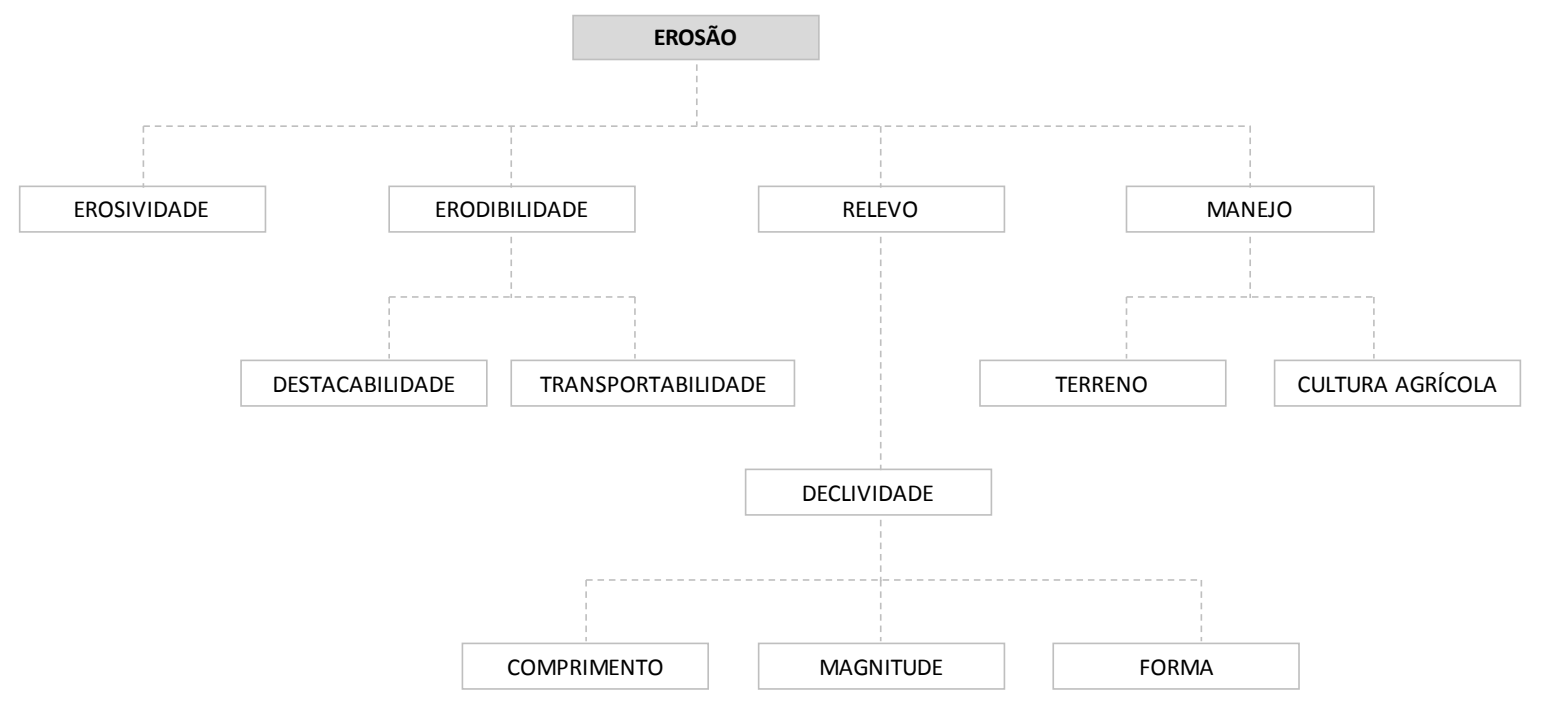

Fonte: Adaptado de Barrow (1991).

\subsubsection{Tipos de erosão}

A erosão pode ser causada por diferentes agentes, como água, gelo e vento, que por sua vez estão relacionados com uma série de fatores naturais como: clima, geomorfologia, substrato rochoso, materiais inconsolidados e cobertura vegetal. A Tabela 1 apresenta os diferentes tipos de erosão e os agentes deflagradores.

Tabela 1 - Tipos de erosão e agentes causadores.

\begin{tabular}{|c|c|c|c|c|}
\hline \multicolumn{4}{|c|}{ Tipo de agente } & Tipo de erosão \\
\hline \multicolumn{4}{|c|}{ Vento } & Eólica \\
\hline \multirow{8}{*}{ Fluidos } & \multirow{7}{*}{ Água } & \multicolumn{2}{|c|}{ Chuva } & Pelo impacto das gotas \\
\hline & & \multirow{5}{*}{ Escoamento } & \multirow{4}{*}{ Superficial } & Sulcos \\
\hline & & & & Ravinas \\
\hline & & & & Voçorocas \\
\hline & & & & Canais Fluviais \\
\hline & & & Subsuperficial & Em condutos subterrâneos \\
\hline & & \multicolumn{2}{|c|}{ Oceano } & Costeira \\
\hline & \multicolumn{4}{|c|}{ Glacial } \\
\hline \multirow{4}{*}{ Gravidade } & \multirow{4}{*}{\multicolumn{3}{|c|}{ Movimento de massa }} & Avalanche \\
\hline & & & & Escorregamento \\
\hline & & & & Solifluxão \\
\hline & & & & Rastejo \\
\hline
\end{tabular}

Fonte: Adaptado de Lal (1990).

\subsubsection{Erosão Eólica}

Consiste na desagregação e remoção das partículas do solo e rocha, devido à ação do vento, que possui capacidade suficiente para deslocar e elevar as partículas, que podem ser 
movimentadas, entrando em estado de suspensão ou saltação. Este tipo de erosão ocorre em áreas com ausência de precipitação e predomínio de altas temperaturas, ou seja, em regiões áridas (ZACHAR, 1982).

Segundo Bertoni e Lombardi Neto (1990) a ação do vento ocasiona a remoção de partículas de solo, rochas e minerais presentes na superfície, especificamente nas rochas, sua ação se deve a abrasão, devido à presença dos grãos de areia e partículas de solo em movimento.

\subsubsection{Erosão Glacial}

A erosão glacial ocorre em locais com baixas temperaturas, onde o gelo atua desfragmentando e carreando fragmentos rochosos, de maneira semelhante à ação da água. No entanto, o processo ocorre com maior velocidade e turbulência, pois o gelo apresenta maior rigidez e capacidade de fundir-se (ZACHAR, 1982).

\subsubsection{Erosão Hídrica}

O processo da erosão hídrica é ocasionado pela ação da água que mobiliza as partículas do solo e também ocasiona o seu transporte. A erosão hídrica está condicionada com as diversas fontes de água existente, como água da chuva (erosão pluvial); água de rios (erosão fluvial); água de lagos (erosão lacustre); água do mar (erosão marinha), entre outras (ZACHAR, 1982).

Segundo Salomão et al. (2012), em países tropicais os processos do meio físico ocorrem sobre forte influência do clima, especificamente das águas, ocasionando diversas consequências, dentre elas, a erosão hídrica. De acordo com Guerra (1998), em regiões de clima tropical, a erosão causada pela água da chuva ocorre devido aos índices pluviométricos elevados, que podem concentrar-se em determinadas épocas do ano, agravando ainda mais o processo.

Sobre estes processos Vilar e Prandi (1993) afirmam que a gota da chuva, ao incidir sobre o solo, possui capacidade de destacar e movimentar as partículas, a água resultante deste processo infiltra ou condiciona o início do processo de escoamento superficial, que poderá ocorrer sobre a forma de fluxo concentrado ou em forma de filetes, dependendo das condições do terreno e da velocidade da enxurrada. 
Neste contexto, fica evidente que os processos erosivos são condicionados por uma série de fatores que determinam os mecanismos de infiltração da água no solo, seu armazenamento e escoamento. De acordo com Salomão e Iwasa (1995), a compreensão destes processos determina duas condições iniciais distintas, que ocasionam a formação de feições erosivas: o impacto da gota da chuva e o escoamento superficial.

Conforme os referidos autores, o impacto da gota da chuva sobre o solo acarreta apenas a desagregação das partículas do solo, enquanto que o escoamento superficial promove o transporte deste material. Em relação ao escoamento superficial, este pode ocorrer de forma difusa, ocasionando a remoção progressiva e uniforme do solo, resultando em um processo linear, e também de forma concentrada, ocasionando incisões sobre o terreno. É importante ressaltar que todo este processo pode sofrer interferência devido ao tamanho da partícula do solo, conforme mostra a Figura 2.

Figura 2 - Velocidade crítica da água necessária para que ocorra erosão, transporte e deposição, em função do tamanho das partículas.

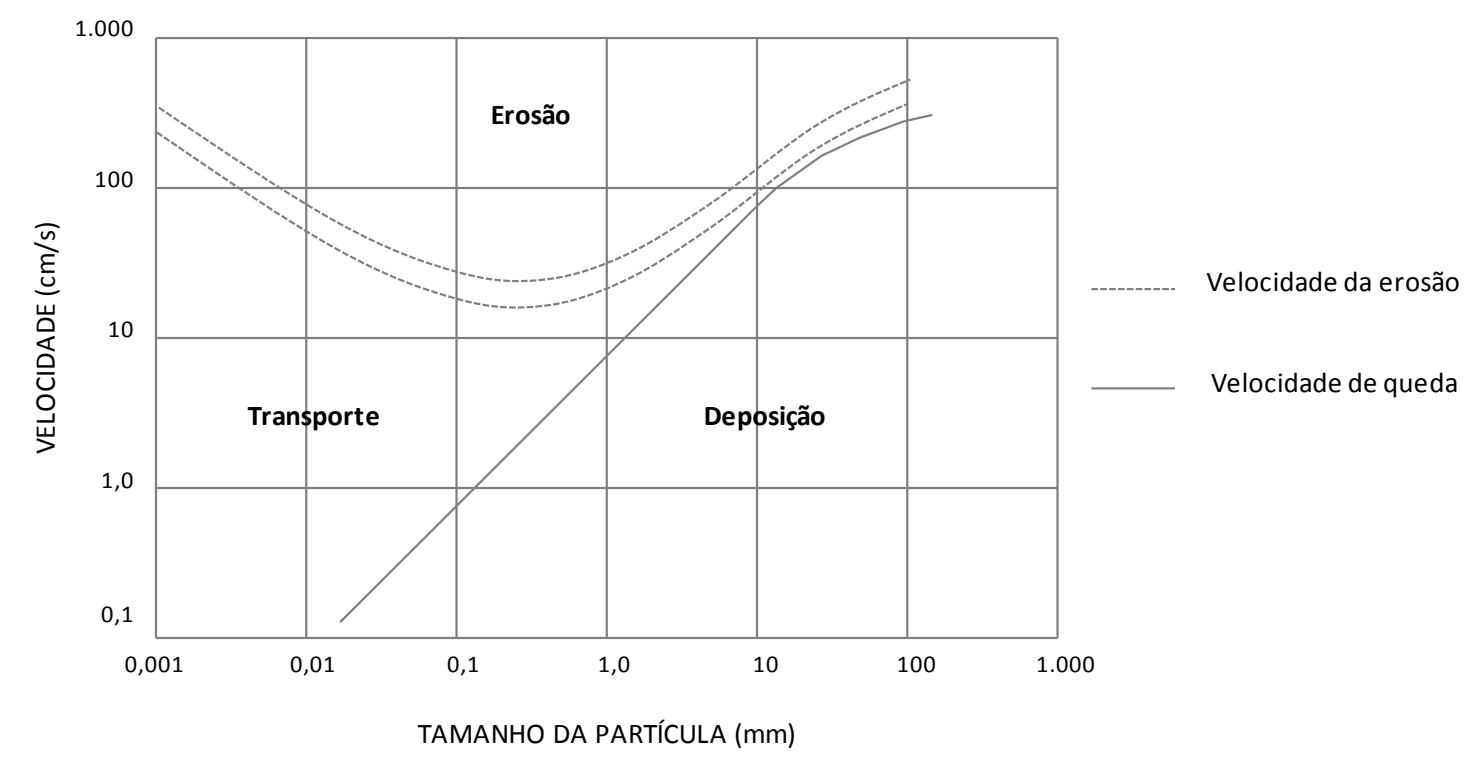

Fonte: Adaptado de Hjulstrom (1935) apud Guerra (1998)

Tanto a erosão natural quanto à acelerada podem ocorrer de forma laminar ou por escoamento concentrado. O processo ocorre de maneira laminar quando não há concentração da água da chuva em canais definidos, na superfície do solo, como um todo. A erosão concentrada ocorre quando há formação de canais de água, em proporções diferentes, desde pequenos sulcos ou ravinas, até voçorocas (PEJON, 1992). 
Desta forma, segundo Guerra (1998), o estudo dos processos erosivos, devido à ação da água, deve ser realizado com base na compreensão dos mecanismos envolvidos na formação das feições. A Tabela 2 apresenta as características relacionadas aos processos envolvidos na formação das erosões hídricas.

Tabela 2 - Processos envolvidos na formação das erosões.

\begin{tabular}{|c|c|}
\hline Processos & Características \\
\hline Infiltração & $\begin{array}{l}\text { - Durante um evento chuvoso, parte da água cai diretamente no solo e outra parte é interceptada pela } \\
\text { vegetação. A água que cai sobre o solo pode infiltrar ou ser armazenada, em relação ao processo de } \\
\text { infiltração, quando o solo não conseguir absorver mais a água, inicia-se o processo de } \\
\text { movimentação das partículas, provocando a formação de feições erosivas; } \\
\text { - As taxas de infiltração podem variar ao longo do evento ou em função das características do solo, no } \\
\text { início do processo tendem a ser mais rápidas e, diminuem quando o solo atinge a capacidade } \\
\text { máxima de absorção; em relação à textura do solo, os arenosos possuem maiores taxas que os } \\
\text { argilosos; } \\
\text { - A compreensão dos mecanismos de infiltração deve ter com base as características da chuva, as } \\
\text { propriedades do solo e encosta. }\end{array}$ \\
\hline $\begin{array}{c}\text { Escoamento } \\
\text { Superficial }\end{array}$ & $\begin{array}{l}\text { - Ocorre quando a capacidade de armazenamento da água no solo é saturada e também quando a } \\
\text { capacidade de infiltração é excedida; } \\
\text { - O fluxo resultante do escoamento superficial raramente se apresenta na forma de um lençol de água, } \\
\text { e sua interação com as gotas da chuva, aumenta sua energia; } \\
\text { - A ausência da cobertura vegetal favorece o impacto das gotas da chuva, o que aumenta os efeitos do } \\
\text { escoamento superficial, e consequentemente a ocorrência de maiores taxas de erosão; } \\
\text { - A remoção da camada de matéria orgânica e nutrientes do solo reduz a resistência do solo frente ao } \\
\text { impacto da gota da chuva, aumentando também as taxas de escoamento superficial. }\end{array}$ \\
\hline $\begin{array}{c}\text { Escoamento } \\
\text { Subsuperficial }\end{array}$ & $\begin{array}{l}\text { - O escoamento superficial afeta diretamente a erodibilidade dos solos, especificamente das suas } \\
\text { propriedades hidráulicas; } \\
\text { - Quando ocorre em fluxos concentrados ocasiona o colapso das camadas superiores do solo, } \\
\text { resultando na formação das voçorocas; } \\
\text { - Pode ocorrer também o movimento lateral da água nas encostas, resultando na redução da } \\
\text { permeabilidade em subsuperfície, que por sua vez, ocasiona o aumento do escoamento } \\
\text { subsuperficial. }\end{array}$ \\
\hline Piping & $\begin{array}{l}\text { - Os dutos (pipes) ou canais abertos em superfície favorecem a formação de fluxos de água em zonas } \\
\text { preferenciais, que transportam material em grande quantidade, e consequentemente induz a } \\
\text { ocorrência de colapsos do solo acima, originando grandes voçorocas; } \\
\text { - Os dutos podem ocorrer nas paredes laterais das voçorocas, provocando a ampliação das feições; } \\
\text { - Nos países frios os dutos ocorrem devido ao derretimento da neve, e nos tropicais devido a chuvas } \\
\text { prolongadas. }\end{array}$ \\
\hline Splash & $\begin{array}{l}\text { Este tipo de erosão ocorre como um resultado das forças devido ao impacto da gota da chuva, que } \\
\text { possuem capacidade de remover as partículas; } \\
\text { - Se em um determinado evento a erosividade da chuva for constante, o fluxo do solo devido ao } \\
\text { impacto é dado em função do gradiente da encosta, uma vez que a distância média dependente da } \\
\text { declividade; } \\
\text { - O efeito splash pode ocasionar também a formação de uma crosta na superfície, ou seja, uma } \\
\text { camada mais resistente à energia cinética da chuva, reduzindo assim a sua ação erosiva. Deve-se } \\
\text { considerar também que a crosta reduz a infiltração e aumenta o escoamento superficial. }\end{array}$ \\
\hline
\end{tabular}

Fonte: Adaptado de Guerra (1998).

\subsubsection{Feições erosivas}

O processo da erosão hídrica tem início com o impacto da gota da chuva que condiciona a formação do processo de escoamento superficial e o surgimento da erosão laminar. À medida que a água escoa sobre a encosta, a velocidade do fluxo aumenta, 
originando incisões maiores no solo, denominadas ravinas, que são canais contínuos. Devido à ação do escoamento superficial e subsuperficial as ravinas podem alargar e originar as voçorocas, que são canais mais largos e profundos (GUERRA, 1998).

Segundo Pejon (1992) os sulcos ou ravinas se caracterizam por apresentar dimensões relativamente pequenas, enquanto que as voçorocas podem atingir grandes áreas, ocasionando a formação de canais com dezenas de metros, que muitas vezes interceptam o nível d'água, causando consequências tanto no meio urbano como rural.

\subsubsection{Erosão laminar (intersulcos)}

A erosão laminar está relacionada com o processo de escoamento superficial que ocorre na encosta de forma dispersa, com profundidade uniforme e sem canais definidos. Este tipo de escoamento está condicionado à ocorrência de chuvas prolongadas e, tem início quando a capacidade de infiltração do solo é excedida (GUERRA, 1998).

Apesar da existência do termo "laminar" na literatura, deve-se considerar que para este tipo de processo não ocorre à formação de uma lâmina de água sobre a encosta, uma vez que não há uma quantidade de água necessária para tal condição, sendo assim, para muitos autores o termo mais adequado para caracterizar este tipo de processo, consiste em erosão “intersulcos”.

Segundo Vilar e Prandi (1993) o termo intersulcos é utilizado para descrever os processos resultantes da formação de um fluxo praticamente uniforme na superfície do solo, devido principalmente a ação da gota da chuva. Este processo é desencadeado pelo escoamento superficial, que propicia o transporte das partículas erodidas.

Para avaliar a perda média de solos por erosão laminar, a partir de um modelo empírico, considerando aspectos ambientais e de manejo do solo, Wishmeier e Smith (1978) propuseram a EUPS (Equação Universal de Perda de Solo) descrita na Equação 1

$$
A=\text { R.K.L.S.C.P }
$$

Onde:

- A = índice que representa a perda de solo por unidade de área;

- $\mathrm{R}=$ índice de erosividade da chuva; 
- $\mathrm{K}=$ índice de erodibilidade;

- $\mathrm{L}=$ índice relativo ao comprimento da encosta;

- $\mathrm{S}=$ índice relativo à declividade da encosta;

- C = índice relacionado ao fator de uso e manejo do solo;

- $\mathrm{P}=$ prática conservacionista adotada.

\subsubsection{Erosão linear}

A erosão linear ocorre devido à concentração do fluxo das águas proveniente do escoamento superficial, que ocasionam a formação de feições erosivas como sulcos e ravinas. Este tipo de erosão pode ocorrer também devido ao fluxo de água subsuperficial e acarretar a formação das voçorocas ou boçorocas (SALOMÃO; IWASA, 1995).

\section{- Sulcos}

Neste tipo de feição erosiva a concentração do fluxo ocorre apenas em alguns pontos do terreno, ocasionando pequenas incisões, que possuem até $0,5 \mathrm{~m}$ de profundidade e são perpendiculares às curvas de nível (BERTONI; LOMBARDI NETO, 1990; SANTORO, 2009). Segundo Morgan (1986), os sulcos são caracterizados pelas feições que podem ser recuperadas com operações normais, como o preparo do solo; e estão associadas às trilhas de gados e geralmente ocorrem em locais onde há movimentação de terra. A Figura 3 apresenta um exemplo de feição do tipo, localizada da região de São Pedro (SP).

Figura 3 - Sulco localizado em São Pedro - SP.

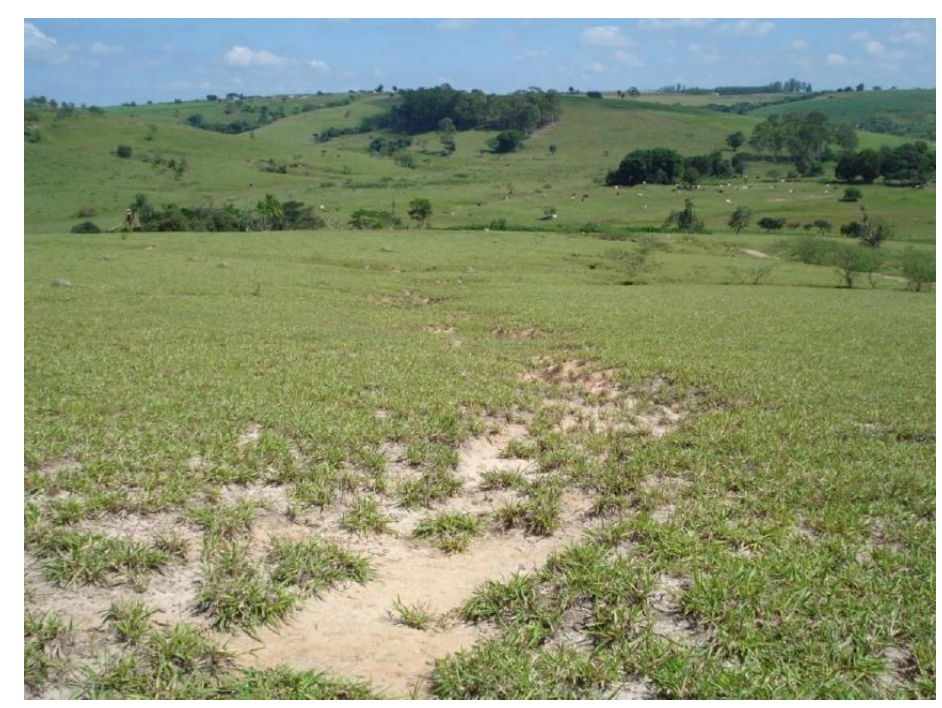

Fonte: Araújo (2011). 


\section{- Ravinas}

A formação das ravinas ocorre em função do aumento da velocidade do fluxo, que por sua vez está relacionado com o aumento da intensidade da chuva, do gradiente da encosta ou também quando a capacidade de armazenamento de água no solo é excedida. As ravinas são feições com características efêmeras, descontínuas e se originam após um evento chuvoso. No entanto, novos eventos podem ocasionar o surgimento de novas feições, que não apresentam relação com aquelas existentes. Estas feições têm sua origem relacionada com o desmatamento e uso intensivo de terras agrícolas, especialmente em períodos de chuvas concentradas, onde o solo permanece desprotegido (GUERRA, 1998). A Figura 4 ilustra uma feição erosiva do tipo ravina localizada no município de São Pedro (SP).

As características do fluxo que originam as ravinas podem ser divididas em quatro estágios: escoamento superficial difuso; escoamento superficial com concentração em pontos preferenciais; escoamento concentrado em microcanais, sem cabeceira definida e escoamento concentrado em microcanais com cabeceiras definidas (MORGAN, 1986).

Figura 4 - Ravina localizada em São Pedro - SP.

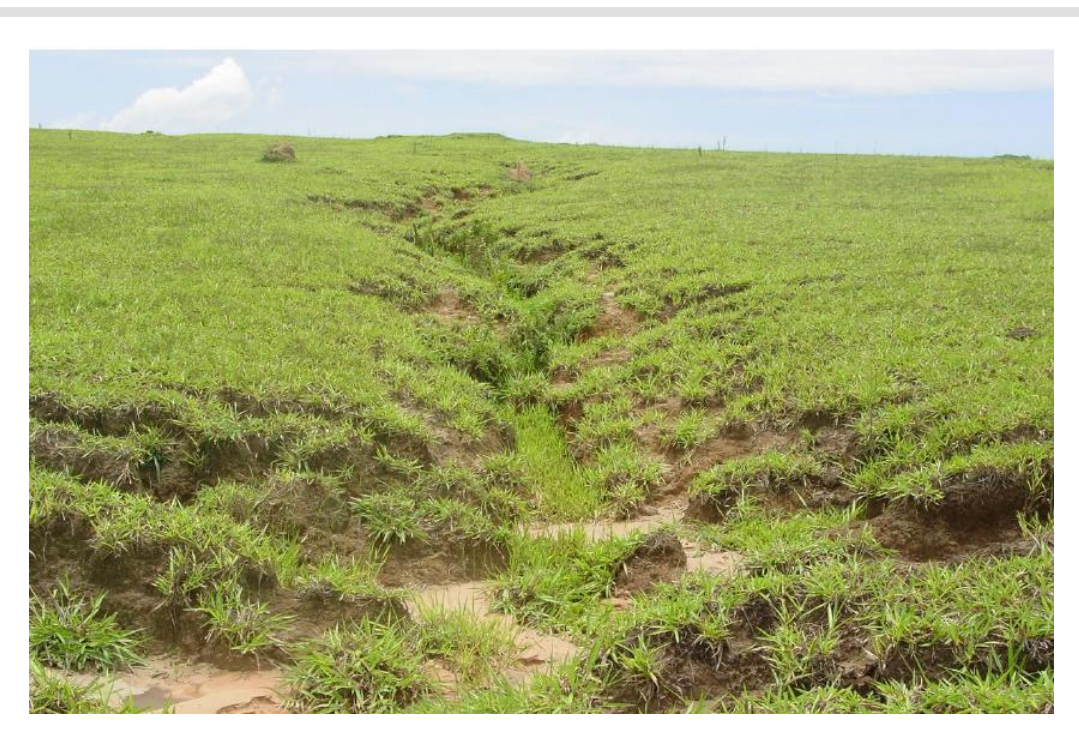

Fonte: Araújo (2011).

- Voçorocas

As voçorocas são feições erosivas profundas; de características permanentes; possuem paredes íngremes; geralmente, fundo chato; presença de água no seu interior; e dependendo da profundidade podem atingir o lençol freático. A ocorrência das voçorocas está associada com processos de erosão acelerada, que ocasionam instabilidade da paisagem, e com o alargamento e aprofundamento de ravinas. Atividades como desmatamento, uso agrícola de 
terra, superpastoreio e queimadas associadas com o tipo de chuva e propriedades do solo podem ocasionar o surgimento destas feições (GUERRA, 1998).

A ocorrência destas feições também pode ter sua origem devido ao escoamento subsuperficial. Assim, de acordo com Salomão e Iwasa (1995), quando os processos erosivos ocorrem devido à ação do escoamento superficial e também do fluxo subsuperficial, às voçorocas podem evoluir por um tipo de processo erosivo denominado erosão interna ou tubular, que originam o piping, que promove a retirada de partículas do interior do solo e consequentemente leva a ocorrência de colapsos.

Segundo os autores, as voçorocas se caracterizam pela elevada capacidade de destruição do terreno, uma vez que envolvem em seu processo de evolução, diferentes fenômenos: erosão superficial, erosão interna, escorregamentos, desabamentos e solapamentos. De acordo com Morgan (1986), devido às suas especificidades as voçorocas se caracterizam como um processo erosivo acelerado, que ocasionam processos de instabilidade na paisagem.

A Figura 5 mostra um exemplo de feição erosiva do tipo voçoroca, localizada no município de São Pedro (SP), apesar da grande dimensão a feição mostra tendência de estabilização, devido à presença de vegetação no seu interior.

Figura 5 - Voçoroca localizada em São Pedro - SP.

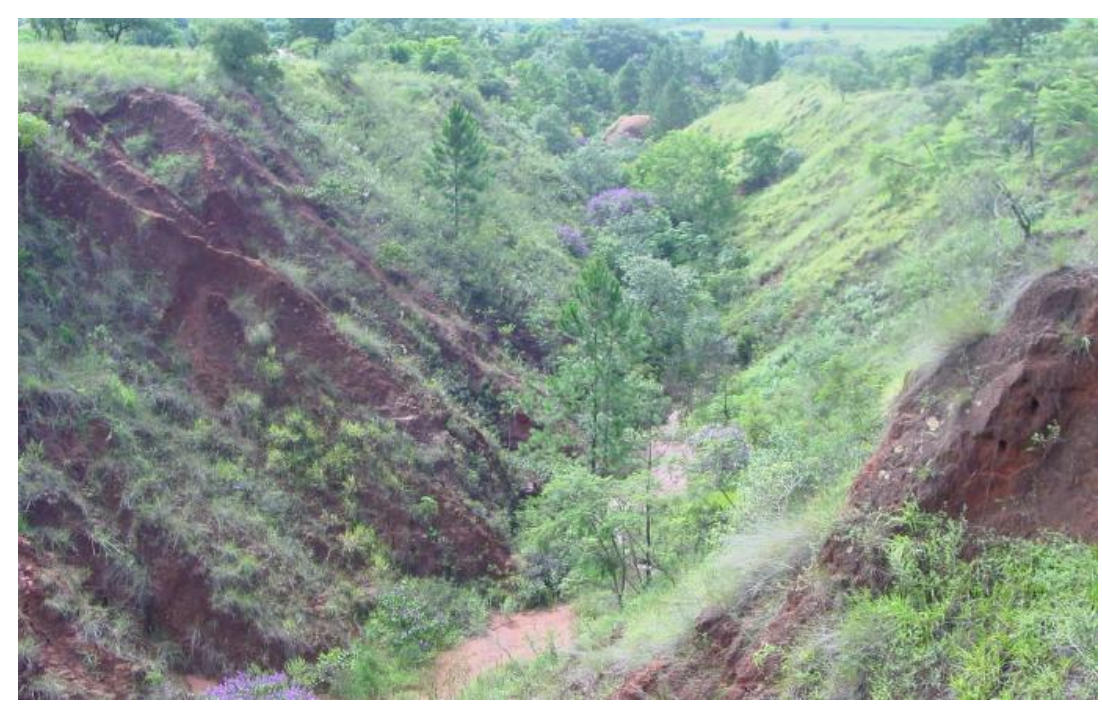

Fonte: Araújo (2011).

A Tabela 3 apresenta uma síntese das principais características dos tipos de feições erosivas laminares - sulcos, ravinas e voçorocas de acordo com Vandaele et al. (1996). 
Tabela 3 - Características das feições erosivas.

\begin{tabular}{|c|c|c|}
\hline Erosão laminar e sulcos & Ravinas & Voçorocas \\
\hline $\begin{array}{c}\text { Ocorre em relevos com declive } \\
\text { bastante suave (sob a linha de } \\
\text { drenagem); }\end{array}$ & $\begin{array}{l}\text { Ocorre em canais de drenagem rasos } \\
\text { (à montante desses canais); }\end{array}$ & $\begin{array}{l}\text { Ocorre, geralmente, bem } \\
\text { definida em canais de } \\
\text { drenagem; }\end{array}$ \\
\hline $\begin{array}{l}\text { Tamanho variado, mas, normalmente, } \\
\text { menor que canais de fluxo } \\
\text { concentrado; }\end{array}$ & $\begin{array}{l}\text { Não possui um tamanho definido, } \\
\text { porém, é intermediário entre o sulco } \\
\text { e a voçoroca; }\end{array}$ & $\begin{array}{c}\text { São bem maiores em largura e } \\
\text { profundidade em relação aos } \\
\text { sulcos e ravinas; }\end{array}$ \\
\hline $\begin{array}{c}\text { O padrão de fluxo desenvolve } \\
\text { pequenos canais paralelos e } \\
\text { desconectados que terminam em canais } \\
\text { de fluxo concentrados; }\end{array}$ & $\begin{array}{l}\text { Normalmente apresenta uma forma } \\
\text { dendrítica, padrão por onde a água } \\
\text { tende a escoar. Esse fluxo é } \\
\text { influenciado, geralmente, por feições } \\
\text { provenientes de atividades agrícolas; }\end{array}$ & $\begin{array}{l}\text { Apresenta um padrão dendrítico } \\
\text { por cursos naturais de } \\
\text { escoamento. Pode ocorrer } \\
\text { também em divisões de canais e } \\
\text { em diques de estradas; }\end{array}$ \\
\hline $\begin{array}{l}\text { Os cortes transversais dos sulcos, } \\
\text { geralmente, são estreitos e poucos } \\
\text { profundos; }\end{array}$ & $\begin{array}{c}\text { Os cortes transversais são geralmente } \\
\text { mais largos e pouco profundos. Suas } \\
\text { paredes laterais não são muito bem } \\
\text { definidas; }\end{array}$ & $\begin{array}{l}\text { Os cortes transversais são } \\
\text { geralmente mais estreitos em } \\
\text { relação à profundidade. Suas } \\
\text { paredes são bastante íngremes; }\end{array}$ \\
\hline $\begin{array}{c}\text { Sulcos removidos pela agricultura, } \\
\text { normalmente não voltam a aparecer no } \\
\text { mesmo lugar; }\end{array}$ & $\begin{array}{l}\text { Feições temporárias, pois podem ser } \\
\text { removidas e/ou recuperadas, por } \\
\text { algum tipo de cultivo de terra; }\end{array}$ & $\begin{array}{l}\text { Não é removida por quaisquer } \\
\text { tipos de cultivo de terra; }\end{array}$ \\
\hline $\begin{array}{l}\text { Baixa taxa de erosão, dificilmente } \\
\text { visível; }\end{array}$ & Podem ou não ser visíveis; & $\begin{array}{l}\text { Erosão facilmente reconhecida e } \\
\text { visível, devido suas grandes } \\
\text { proporções; }\end{array}$ \\
\hline $\begin{array}{c}\text { Separação e transporte por gotas de } \\
\text { chuva e fluxo superficial, } \\
\text { respectivamente; }\end{array}$ & $\begin{array}{l}\text { Separação e transporte por fluxo } \\
\text { superficial; }\end{array}$ & $\begin{array}{l}\text { Destacamento e transporte por } \\
\text { fluxo superficial, com quedas de } \\
\text { bancos instáveis nos canais e } \\
\text { alargamento da cabeceira; }\end{array}$ \\
\hline
\end{tabular}

Fonte: Adaptado de Vandaele et al. (1996).

\subsubsection{Fatores condicionantes}

A ocorrência dos processos erosivos está relacionada com a atuação de forças ativas (características da chuva; declividade; comprimento de rampa e capacidade do solo de absorver água) e forças passivas (resistência do solo à ação erosiva e cobertura vegetal) (BERTONI; LOMBARDI NETO, 1990).

Para Pejon (1992), o surgimento das erosões depende de vários fatores naturais, que combinados com a ação antrópica se intensificam. Os fatores naturais citados pelo autor são: clima, geomorfologia, natureza do terreno (tipo de solo e substrato rochoso) e cobertura vegetal.

É importante destacar que, segundo Vilar e Prandi (1993), no estado de São Paulo, área de estudo desta pesquisa, os processos erosivos estão associados com a ocupação desordenada do meio físico, a concentração de chuvas em determinadas épocas do ano, as formações arenosas presentes em diversas áreas e também devido ao manejo inadequado de áreas agrícolas e obras de engenharia como estradas, loteamentos e expansões urbanas. 


\subsubsection{Clima}

Dentre todos os fatores climáticos, o mais importante é a precipitação. De maneira geral a ação da chuva se deve ao impacto das gotas sobre o solo que favorecem a erosão, pois causam o desprendimento e transporte das partículas (BERTONI; LOMBARDI NETO, 1990).

De acordo com Salomão e Iwasa (1995), a chuva possui capacidade de causar erosão devido ao impacto das gotas sobre a superfície do solo, e também devido à enxurrada que é formada. Assim, sua ação depende da velocidade e energia que cai sobre o solo, que por sua vez, estão relacionadas com a distribuição pluviométrica e intensidade. Segundo Bertoni e Lombardi Neto (1990), a gota da chuva, contribui para a ocorrência dos processos erosivos de três maneiras: desagregando as partículas do solo; devido ao salpicamento, transportando as partículas; e conferindo energia ao escoamento superficial.

A intensidade é o fator pluviométrico de maior importância para a ocorrência dos processos erosivos, e influem diretamente no volume e velocidade da enxurrada. É fundamental que os dados pluviométricos sejam analisados com base nas características de intensidade, duração e frequência. A intensidade se caracteriza como o fator mais importante; a duração de um evento pluviométrico condiciona os mecanismos de infiltração e a formação das enxurradas; e a frequência, assim como a intensidade, influência nas taxas de perda de solo, no teor de umidade e consequentemente no volume das enxurradas (BERTONI; LOMBARDI NETO, 1990).

Segundo os autores citados para analisar a energia cinética da chuva, ou seja, a força com que uma partícula golpeia o solo pode-se utilizar a Equação 2, proposta por Wilkinson (1975).

$$
E c=\left(12,14+8,88 \log I_{30}\right) \times P
$$

Onde:

- $\mathrm{E}_{\mathrm{c}}=$ energia cinética total da chuva $\left(\mathrm{MJ} \mathrm{ha}^{-1} \mathrm{~mm}^{-1}\right)$;

- $\mathrm{I}_{\mathrm{c}}=$ intensidade máxima da chuva em 30 minutos $\left(\mathrm{mm} \mathrm{h}^{-1}\right)$;

- $\mathrm{P}=$ precipitação total da chuva $(\mathrm{mm})$. 
Para expressar a capacidade que a chuva possui de causar a erosão, utiliza-se o índice denominado erosividade, que de acordo com Lal (1994), consiste na capacidade de um agente, como a chuva, causar desagregação e transporte das partículas do solo. Para esse autor, esta capacidade está relacionada com a taxa de distribuição da chuva e ao tamanho da gota, que conferem energia para ocorrer à erosão.

Desta maneira, correlacionando intensidade e energia cinética pode-se determinar o índice de erosividade da chuva (EI), descrito na Equação 3, a partir da metodologia de Wischmeier e Smith (1958):

$$
E I_{30}=E C x I_{30}
$$

Onde:

- $\mathrm{EI}_{30}=$ índice erosivo da chuva $\left(\mathrm{MJ} \mathrm{mm} \mathrm{ha}^{-1} \mathrm{~h}^{-1}\right)$;

- $\mathrm{EC}=$ energia cinética total da chuva $\left(\mathrm{MJ} \mathrm{ha}^{-1} \mathrm{~mm}^{-1}\right)$;

- $\mathrm{I}_{\mathrm{c}}=$ intensidade máxima da chuva em 30 minutos $\left(\mathrm{mm} \mathrm{h}^{-1}\right)$.

\subsubsection{Cobertura vegetal}

A cobertura vegetal é a principal proteção do solo contra os processos erosivos, sendo que Bertoni e Lombardi Neto (1990) citam os benefícios proporcionados pela vegetação: proteção contra o impacto da gota da chuva; interceptação e evaporação da gota; aumentam a taxa de infiltração pela ação das raízes; a presença da matéria orgânica melhora a estrutura do solo, aumentando a sua capacidade de retenção de água; reduz a velocidade do escoamento da enxurrada. Vilar e Prandi (1993) afirmam, também, que a presença da vegetação proporciona um aumento da resistência do solo e favorecem a formação de agregados mais estáveis.

\subsubsection{Fatores topográficos}

É representado pela declividade, comprimento de rampa e forma das encostas, que interferem diretamente na velocidade do escoamento superficial (VILAR; PRANDI, 1993). Segundo Pejon (1992), o fenômeno da erosão está relacionado com um conjunto de fatores combinados, dentre eles a declividade é um dos mais importantes na análise do processo de escoamento superficial, bem como na avaliação da suscetibilidade do terreno a erosão. 
De acordo com Bertoni e Lombardi Neto (1990), o comprimento de rampa, interfere no volume e velocidade do escoamento superficial, consequentemente interfere na energia resultante, que ocasiona maior ou menor formação de feições erosivas.

Ruhe (1975) propõem uma classificação das encostas em relação a inclinação, comprimento e largura do declive, sendo linear (L), côncava (C) e convexa (V). A partir desta classificação podem ser definidos nove tipos de formas geométricas, divididos em três grupos (Figura 6). Cada um destes tipos de encostas interfere de maneira distinta na ocorrência dos processos erosivos e consequentemente na formação de diferentes condições de concentração de fluxo de água.

Figura 6 - Classificação das encostas proposta por Ruhe (1975).

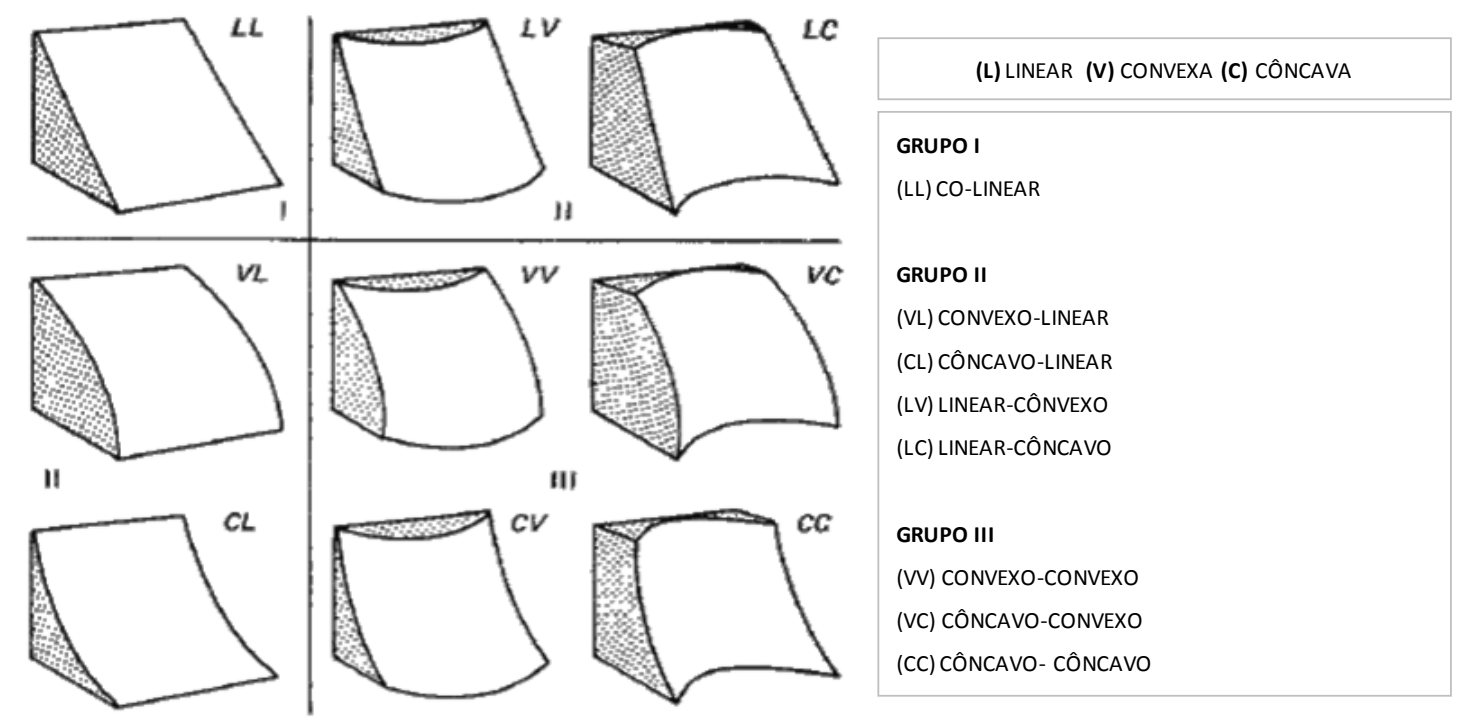

Fonte: Adaptado de XuJiongxin, 1996.

Vilar (1989), ao propor um modelo matemático para representação da erosão causada pela água da chuva, verificou que as taxas de solo erodido, estão condicionadas a forma da encosta, assim, na encosta convexa a perda de solo é mais acentuada, seguida pelas encostas retilíneas, convexo-côncava e côncava.

\subsubsection{Solos}

As características físicas, químicas e biológicas do solo exercem diferentes influências nos processos erosivos. Estas propriedades conferem resistência ao solo e determinam um comportamento diferente frente a condições semelhantes. De acordo com Vilar e Prandi (1993), a natureza do solo é um fator fundamental para ocorrência dos processos erosivos, as 
suas características hidrológicas determinam as taxas de infiltração e as hidráulicas as variáveis do fluxo.

Conforme Salomão e Iwasa (1995), as propriedades do solo que conferem maior ou menor resistência em relação à ação das águas, são: textura, estrutura, permeabilidade, densidade, bem como as características químicas, biológicas e mineralógicas (Tabela 4).

Tabela 4 - Características dos solos que interferem nos processos erosivos.

\begin{tabular}{c|l}
\hline Propriedades & \multicolumn{1}{c}{ Características } \\
\hline Textura & - $\begin{array}{l}\text { Está relacionada com a capacidade de infiltração e absorção da água da chuva; } \\
\text { Interfere no fluxo do escoamento superficial. }\end{array}$ \\
\hline Estrutura & $\begin{array}{l}\text { Como a textura, influencia na capacidade de infiltração e absorção da água, e também } \\
\text { na capacidade de arraste das partículas do solo; }\end{array}$ \\
\hline - Solos com estrutura microagregada apresentam alta permeabilidade e maior resistência \\
ao arraste de partículas pela ação da água da chuva.
\end{tabular}

Fonte: Adaptado de Salomão e Iwasa (1995).

Outro fator de fundamental importância é a erodibilidade dos solos, que segundo Lal (1994) consiste na suscetibilidade do solo quanto à desagregação e transporte das partículas e, está relacionada com a textura, estrutura, matéria orgânica, mineralogia das argilas e composição química.

Segundo Vilar e Prandi (1993), a erodibilidade dos solos indica a maior ou menor aptidão das partículas resistirem aos esforços causados pelos agentes condicionantes dos processos erosivos, e por isso, está intimamente relacionada com a resistência do solo, que pode ser comprometida pelos ciclos de umedecimento e secagem e também pela concentração de eletrólitos.

De acordo com Zuquette et al. (2007), diversos métodos têm sido utilizados na avaliação da erodibilidade dos solos, e podem ser divididos em diretos e indiretos (Tabela 5). 
Tabela 5 - Exemplos de ensaios para avaliação da erodibilidade dos solos.

\begin{tabular}{c|c|c}
\hline \multirow{3}{*}{ Método } & Ensaio & Autor \\
\hline \multirow{4}{*}{ Indiretos } & Estimativa do Fator K(Eups) & Wishmeier et al. (1971) \\
\cline { 2 - 3 } & Método MCT (Miniatura compactada tropical) & Vertamatti e Araujo (1990) \\
\cline { 2 - 3 } Diretos & Índice Bouyoucos & Morgan (1986) \\
\cline { 2 - 3 } & Ensaio de Inderbitzen & Inderbitzen (1961) \\
\cline { 2 - 3 } & Índice de erodibilidade $(\mathrm{E}=52 \mathrm{~S} / \mathrm{P})^{*}$ & Nogami e Villibor (1979) \\
\cline { 2 - 3 } & Índice de erodibilidade $(\mathrm{E}=40 \mathrm{~S} / \mathrm{P})^{*}$ & Pejon (1992) \\
\cline { 2 - 3 } & Ensaio de Pinhole & Sherad et al. (1976) \\
\hline
\end{tabular}

(*) S: índice de absorção de água; P: perda de água por imersão.

Fonte: Adaptado de Zuquette et al. (2007).

Segundo Fendrich et al. (1997), os solos mais propícios à formação das voçorocas são essencialmente arenosos, pouco coesivos, coluviais e porosos. Estes solos geralmente apresentam o horizonte A constituído por areia muito fina, siltosa e pouco argilosa, e o horizonte B composto por camadas de arenito mais resistentes, e camadas de argilas estratificadas.

Em relação à presença de argilas, segundo Vilar e Prandi (1993), estas podem favorecer a ocorrência de erosões, uma vez que ciclos de umedecimento e secagem, em conjunto com variações nas temperaturas, induzem a expansão e retração dos argilo-minerais, este processo independe da ação da chuva e ocorre em solos saprolíticos.

Além dos solos, é importante destacar o papel do substrato rochoso, conforme Infanti Jr. e Fornassari Filho (1998) as características litológicas associadas ao processo de intemperismo, em conjunto com a natureza da alteração e o grau de fraturamento da rocha, indicam sua influência na suscetibilidade à erosão.

\subsubsection{Ação Antrópica}

Além destes condicionantes naturais, Fendrich et al. (1997); Pejon (1992); Santoro (2009) e outros autores descrevem a ação antrópica como um fator que favorece a ocorrência de erosões aceleradas. Algumas das formas de intervenção humana no processo natural são: remoção da cobertura vegetal; agricultura com manejo inadequado; formação de pastos com alta densidade de animais; aberturas de valetas perpendiculares às curvas de nível; abertura de estradas sem a execução de obras de drenagem e execução de loteamentos sem controle do uso do solo. 
A Tabela 6 apresenta diversos aspectos relacionados com os agentes deflagradores dos processos erosivos, compilados por Dantas-Ferreira (2004) a partir de diversos autores.

Tabela 6 - Agentes deflagradores dos processos erosivos

\begin{tabular}{|c|c|}
\hline Fatores & Características \\
\hline & $\begin{array}{l}\text { - Um dos fatores climáticos de maior importância na erosão dos solos; } \\
\text { - O volume e a velocidade da enxurrada dependem da intensidade, duração e frequência da chuva; } \\
\text { - A intensidade é o fator pluviométrico mais importante na erosão; } \\
\text { - Em regiões tropicais, o efeito de degradação pelo clima está aliada à chuva e sua capacidade de } \\
\text { causar erosão; }\end{array}$ \\
\hline Chuva & $\begin{array}{l}\text { - São considerados dois agentes erosivos distintos, a gota de chuva e o escoamento superficial; } \\
\text { - A evolução do processo erosivo está ligada à quantidade de água excedente que escoa na } \\
\text { encosta; } \\
\text { - Os processos erosivos são mais atuantes e energéticos nos períodos mais chuvosos e, por isso, é } \\
\text { importante estabelecer os índices pluviométricos; } \\
\text { - A infiltração e o escoamento superficial são dois processos formados a partir da precipitação } \\
\text { pluviométrica e do impacto da gota de chuva, estes contribuem para o desenvolvimento de uma } \\
\text { feição erosiva; }\end{array}$ \\
\hline Topografia & $\begin{array}{l}\text { - Agentes geomorfológicos desencadeares na formação de voçorocas deve ser considerada em } \\
\text { escala maior: as características típicas das encostas e suas feições particulares e em escala } \\
\text { menor: processos de modelado cujos últimos eventos refletem a cobertura vegetal; } \\
\text { - A influência da topografia do terreno na intensidade erosiva manifesta-se principalmente pela } \\
\text { declividade e comprimento da rampa (comprimento da encosta); } \\
\text { - Se a declividade aumenta quatro vezes, a velocidade de escoamento aumenta duas vezes e a } \\
\text { capacidade erosiva quadruplica; }\end{array}$ \\
\hline $\begin{array}{c}\text { Natureza } \\
\text { do Solo }\end{array}$ & $\begin{array}{l}\text { O solo tem um papel essencial nos estudos sobre os mecanismos do processo erosivo, devido } \\
\text { suas características e interação com os outros fatores; } \\
\text { - A degradação das propriedades físicas do solo é um dos principais processos responsáveis pela } \\
\text { perda da qualidade estrutural e aumento da erosão hídrica; } \\
\text { - As propriedades do solo que afetam a erosão são: textura, estrutura, densidade aparente, } \\
\text { permeabilidade e teor de matéria orgânica; } \\
\text { - As propriedades dos solos exercem diferentes influências na erosão, ao conferir maior ou menor } \\
\text { resistência à ação das águas; }\end{array}$ \\
\hline $\begin{array}{c}\text { Cobertura } \\
\text { Vegetal }\end{array}$ & $\begin{array}{l}\text { - A vegetação desempenha um papel importante, pois promove uma distribuição mais difusa da } \\
\text { água de escoamento pluvial, dificultando a instalação da erosão; } \\
\text { - Em terrenos descobertos, a enxurrada faz desprender e salpicar as partículas de solo, que são } \\
\text { facilmente transportadas pela água; } \\
\text { - Ao decompor-se, aumenta o conteúdo de matéria orgânica e de húmus do solo, melhorando-lhe a } \\
\text { porosidade e a capacidade de retenção da água; }\end{array}$ \\
\hline $\begin{array}{c}\text { Ação } \\
\text { Antrópica }\end{array}$ & $\begin{array}{l}\text { É o principal fator na deflagração dos processos erosivos; } \\
\text { - A intervenção humana no meio, com o desmatamento, seguido ou não de exploração econômica, } \\
\text { implantação de obras civis e/ou núcleos urbano altera sua estabilidade; } \\
\text { - A readaptação à nova condição se manifesta na força de intensificação dos processos erosivos; } \\
\text { - A modificação das encostas provocam alterações significativas na relação escoamento } \\
\text { superficial/armazenamento hídrico do solo, provocando alterações na bacia; } \\
\text { - As seguintes atividades influenciam no desencadeamento dos processos erosivos: ocupação } \\
\text { desordenada das encostas e fundo de vales, construção de barragens e desmatamentos. }\end{array}$ \\
\hline
\end{tabular}

Fonte: Dantas-Ferreira, 2004. 


\subsection{Avaliação dos processos erosivos}

A avaliação da erosão hídrica deve ter como base a definição dos fatores que condicionam a erosão, para isto, são utilizadas técnicas de levantamento em campo, ensaios e análises que permitam o estabelecimento das relações existentes entre estes fatores. As análises também podem incluir a avaliação espacial e temporal, com a finalidade de identificar as variáveis de causa e efeito, favorecendo a elaboração de equações que descrevam os processos que intervém na ocorrência das erosões (ALMOROX et al., 2010).

Neste contexto, o autor citado propõe dois métodos de avaliação da erosão (Figura 7). A avaliação qualitativa é realizada com base na forma e grau da erosão e a avaliação quantitativa considera as características pertinentes deste fenômeno. Dentre estes métodos, destaca-se a avaliação quantitativa que permite a representação numérica do processo, com base em parâmetros de ensaios, e também a avaliação por meio de modelos físicos, estatísticos e paramétricos.

Figura 7 - Métodos de avaliação da erosão hídrica.

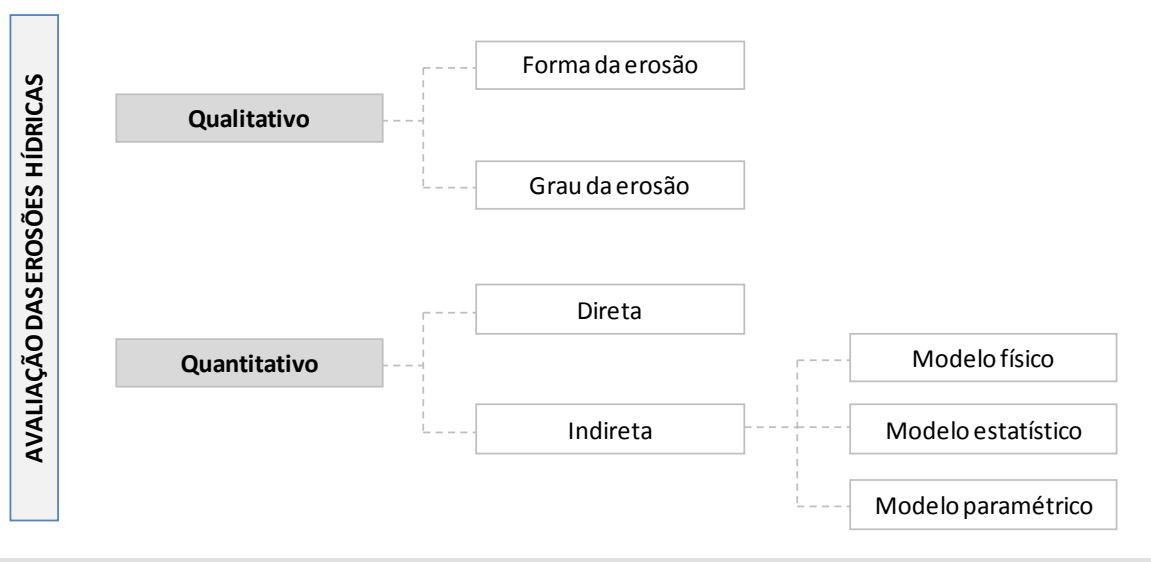

Fonte: Almorox et al. (2010).

\subsubsection{Modelos estatísticos, físicos e paramétricos}

Segundo Almorox et al. (2010), os modelos físicos permitem a compreensão dos mecanismos da erosão com base nas leis da física, que governam a geração e transporte dos sedimentos; os modelos conceituais permitem a representação dos diversos processos, como geração, transferência e armazenamento a partir de modelos hidrológicos; os modelos paramétricos associam os fatores de causa e efeito com formulações empíricas; e os modelos estatísticos relacionam as medidas de degradação com parâmetros relacionados aos processos 
erosivos, como clima e relevo. A Tabela 7 apresenta exemplos de modelos que podem ser aplicados na avaliação indireta.

Tabela 7 - Modelos de avaliação quantitativa indireta das erosões.

\begin{tabular}{|c|c|c|}
\hline Tipo & Autor & Modelo \\
\hline \multirow{2}{*}{ Paramétricos } & Wischmeier e Smith (1978) & USLE \\
\hline & Renard et al. (1997) & RUSLE \\
\hline \multirow{3}{*}{ Conceituais } & Young et al. (1989) & AGNPS (Agricultural Now-Point Source) \\
\hline & Wilkinson (2004) & SEDNET \\
\hline & Neitsch (2004) & SWAT (Soil and water assessment tool) \\
\hline \multirow{11}{*}{ Base Física } & Beasley (1977) & $\begin{array}{c}\text { ANSWERS (Areal Non-Point Source Watershed } \\
\text { Environment Response Simulation) }\end{array}$ \\
\hline & Schmidt et al. (1999) & EROSION-3D \\
\hline & Morgan et al. (1998) & EUROSEN (Europen Soil Erosion Model) \\
\hline & Rose et al. (1997) & GUEST (Griffith University Erosion System Template) \\
\hline & Smith et al. (1995) & KINEROS (Kinematic Erosion Simulation) \\
\hline & De Roo (1996) & LISEM (Limburg Soil Erosion Model) \\
\hline & Nunes (2005) & MEFIDIS (Modelo de erosão físico distribuído) \\
\hline & Kirkby et al. (2004) & PESERA (Pan-Europen Soil Erosion Risk Assessment) \\
\hline & Montgomery e Dietrich (1994) & SHALSTAB \\
\hline & O’Loughlin (1986) & TOPOG \\
\hline & Laflen et al. (1991) & WEPP (Water Erosion Prediction Project) \\
\hline
\end{tabular}

Fonte: Almorox et al. (2010); Furegatti (2012).

Dentre os modelos paramétricos, de predição da erosão hídrica, os métodos baseados na Equação Universal de Perda de Solos (USLE) são os mais conhecidos, pois se caracteriza como um método simples para previsão de perda de solo. A partir da aplicação da USLE pode-se prever as perdas anuais de solo; as alterações nas perdas ocasionadas por mudanças nas práticas de cultivo; propor práticas conservacionistas conforme a previsão da perda de solo, entre outras aplicações (RANIERI, 1996).

Em relação aos modelos conceituais, Furegatti (2012) cita que são necessárias informações detalhadas da bacia para realização da descrição dos processos a serem analisados. Dentre os modelos citados o SWAT é aplicado em escala de bacia ou sub-bacia hidrográfica, mas não considera erosões lineares, diferente do AGNPS que pode ser aplicado para análise de erosões do tipo ravinas (efêmeras ou pertinentes).

Segundo a autora citada, os modelos de base física podem ser subdivididos em três grupos com base no evento de chuva, na sua continuidade e distribuição espacial. Quanto às características dos processos erosivos analisados, ressalta-se que poucos consideram a perda de solo por erosão linear. Os modelos que consideram erosão linear do tipo sulco são: 
ANSWERS, EUROSEN, GUEST, LISEN, MEFIDIS e WEPP, destes, apenas o ASWERS considera os efeitos da voçoroca para distinguir a quantidade de sedimento.

Os parâmetros de entrada destes modelos são obtidos a partir de ensaios de campo; laboratório; cartas topográficas e geológicas e interpretação de fotos aéreas. Os ensaios específicos utilizados para obtenção destes parâmetros são: simulador de chuva; resistência do solo à penetração e ensaio de infiltração com duplo anel. Os dados obtidos são inseridos nos programas através de banco de dados ou arquivos matriciais, no formato raster. Por fim, em relação à escala deve-se considerar o nível de detalhamento de cada modelo (FUREGATTI, 2012).

No entanto, como citado por Kuwajima (2012), muitos destes modelos foram projetados para simular erosões que ocorrem em regiões, com clima e pedologia diferente dos países tropicais. Assim sendo, torna-se fundamental a modificação dos parâmetros e equações para que a simulação esteja em conformidade com as características reais da área; a criação de um banco de dados de solo, manejo de culturas e uso e ocupação, específicos para regiões tropicais. A qualidade e disponibilidade destes dados se refletem de maneira significativa na operação e calibração do modelo.

Apesar de todas as limitações referentes aos parâmetros de entrada, o autor, verificou que modelos de base física, como o SWAT, são eficazes na avaliação da produção de sedimentos e por isso, são ferramentas fundamentais para o desenvolvimento de estudos hidrossedimentológicos, que tem por objetivo o monitoramento do assoreamento em corpos d'água e barragens.

\section{4 Índices que relacionam área de contribuição $x$ declividade}

O surgimento das feições erosivas está relacionado com diversos fatores naturais, como chuva, solo, substrato rochoso, relevo, e cobertura vegetal. Além destes fatores, existe uma condição morfométrica, determinada em função da relação entre área de contribuição e declividade, que influencia o desencadeamento das feições lineares.

Patton e Schumm (1975) foram os primeiros autores na literatura a estabelecerem uma correlação entre o surgimento das erosões e características morfométricas, a partir de uma relação de potência entre área da bacia de drenagem (A) e declividade crítica (S). Considerando esta relação os autores analisaram o limiar crítico de feições erosivas do tipo 
linear e laminar, localizadas no Colorado. A Figura 8 apresenta o gráfico obtido por estes autores.

Figura 8 - Gráfico SxA para erosões laminares (Colorado).

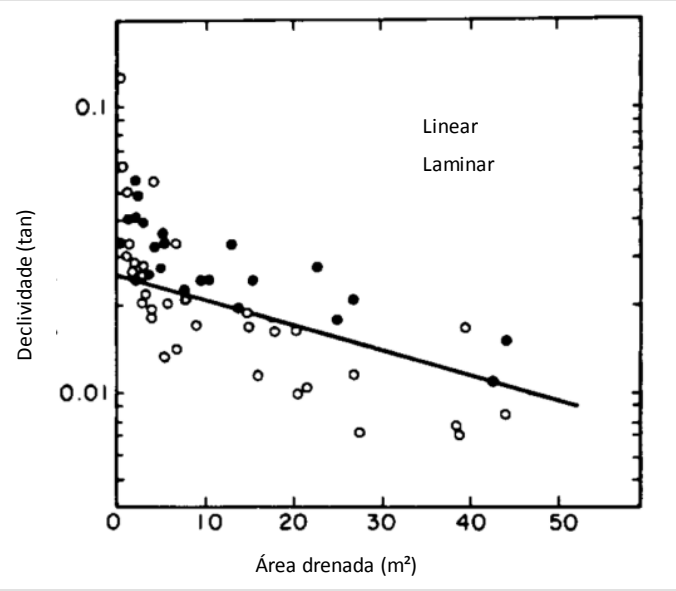

Fonte: Adaptado de Patton e Schumm (1975).

A partir desta relação Begim e Schumm (1979) e Montgomery e Dietrich (1994) propuseram as primeiras equações para representar o limiar crítico de desencadeamento das erosões, levando em consideração o princípio de Horton (1945), que afirma que o surgimento dos canais ocorre quando a tensão de cisalhamento provocada pelo escoamento superficial excede o limiar de resistência do solo. No âmbito da geomorfologia este conceito é aplicado pressupondo que existe uma relação entre declividade (S) e área de drenagem (A), que condiciona o escoamento superficial necessário para dar início à erosão. Esta relação é expressa pela Equação 4, onde $a$ e $-b$ são coeficientes, que indicam a posição e inclinação da reta, e dependem das características do ambiente.

$$
S=a A^{-b}
$$

Os parâmetros área de contribuição e declividade podem ser obtidos por diferentes métodos, como: levantamento de campo, fotografia aérea, mapa topográfico, modelo digital de elevação e também por meio do processamento automático em SIG. A Tabela 8 apresenta um levantamento realizado por Vandaele et al. (1996) e a relação dos diferentes métodos que podem ser utilizados.

Tabela 8 - Métodos e fontes de informação utilizadas (Continua).

\begin{tabular}{c|c|c|c|c|c}
\hline Autores & $\begin{array}{c}\text { Área de } \\
\text { estudo }\end{array}$ & Método & Declividade & $\begin{array}{c}\text { Área de } \\
\text { drenagem }\end{array}$ & $\begin{array}{c}\text { Processo } \\
\text { analisado }\end{array}$ \\
\hline $\begin{array}{c}\text { Patton e } \\
\text { Schumm (1975) }\end{array}$ & Colorado & $\begin{array}{c}\text { Fotografia } \\
\text { aérea }\end{array}$ & $\begin{array}{c}\text { Mapa topográfico } \\
(1: 50.000)\end{array}$ & Mapa topográfico & $\begin{array}{c}\text { Canais } \\
\text { descontínuos }\end{array}$ \\
\hline I.G.N. (1983) & França & $\begin{array}{c}\text { Fotografia } \\
\text { aérea }\end{array}$ & $\begin{array}{c}\text { Mapa topográfico } \\
(1: 10.000)\end{array}$ & Mapa topográfico & Ravinas \\
\hline
\end{tabular}




\begin{tabular}{|c|c|c|c|c|c|}
\hline Autores & $\begin{array}{l}\text { Área de } \\
\text { estudo }\end{array}$ & Método & Declividade & $\begin{array}{c}\text { Área de } \\
\text { drenagem }\end{array}$ & $\begin{array}{c}\text { Processo } \\
\text { analisado }\end{array}$ \\
\hline $\begin{array}{l}\text { Montgomery e } \\
\text { Dietrich (1988) }\end{array}$ & $\begin{array}{c}\text { Califórnia e } \\
\text { Oregon }\end{array}$ & $\begin{array}{l}\text { Trabalho de } \\
\text { campo }\end{array}$ & $\begin{array}{c}\text { Mensuração em } \\
\text { campo }\end{array}$ & $\begin{array}{c}\text { Mapa } \\
\text { planialtimétrico }\end{array}$ & $\begin{array}{c}\text { Deslizamento e } \\
\text { esocoamento } \\
\text { superficial }\end{array}$ \\
\hline $\begin{array}{c}\text { Vandaele et al. } \\
(1995)\end{array}$ & Bélgica & $\begin{array}{c}\text { Fotografia } \\
\text { aérea }\end{array}$ & $\begin{array}{c}\text { Mapa topográfico } \\
(1: 10.000)\end{array}$ & SIG & Ravinas \\
\hline $\begin{array}{l}\text { Poesen et al. } \\
\text { (1995) }\end{array}$ & Bélgica & $\begin{array}{l}\text { Trabalho de } \\
\text { campo }\end{array}$ & $\begin{array}{l}\text { Mensuração em } \\
\text { campo }\end{array}$ & $\begin{array}{l}\text { Mensuração em } \\
\text { campo }\end{array}$ & Ravinas \\
\hline $\begin{array}{c}\text { Vandaele et al. } \\
(1995)\end{array}$ & Portugal & $\begin{array}{c}\text { Fotografia } \\
\text { aérea }\end{array}$ & $\begin{array}{c}\text { Mapa topográfico } \\
(1: 10.000)\end{array}$ & SIG & Ravinas \\
\hline
\end{tabular}

Fonte: Adaptado de Vandaele et al. (1996).

Dentre estes métodos destaca-se a aplicação do SIG no trabalho de Vandaele et al. (1995) que calcularam a área de drenagem e declividade com base no modelo digital de elevação, utilizando algoritmos propostos por outros autores.

A partir da relação estabelecida por Patton e Schumm (1975) diversos estudos foram desenvolvidos: Montgomery e Dietrich (1994); Vanwalleghem et al. (2005); e MenéndezDuarte et al. (2007), entre outros. A Tabela 9 apresenta a relação com alguns destes estudos levantadas por Torri e Poesen (2014) juntamente com o trabalho de Stabile (2015) realiado no Brasil em 2015. Verifica-se que os valores de ' $a$ ' e - ' $b$ ' variam em função das características locais, que são determinadas em função do tipo e cobertura vegetal, clima, substrato rochoso, entre outras.

Tabela 9 - Autores, locais e coeficientes $a$ e $-b$.

\begin{tabular}{c|c|c|c}
\hline Autores & Local & $\boldsymbol{a}$ & $\boldsymbol{-} \boldsymbol{b}$ \\
\hline Patton e Schumm (1975) & EUA & 0,16 & 0,26 \\
\hline Schumm et al. (1980) & EUA & 0,008 & 0,26 \\
\hline Montgomery e Dietrch (1988) & EUA & 0,25 & 0,4 \\
\hline Montgomery e Dietrch (1994) & EUA (Nevada) & 0,09 & 0,50 \\
\hline Montgomery e Dietrch (1994) & EUA (Califórnia) & 0,18 & 0,50 \\
\hline Vandaele et al. (1996) & Bélgica & 0,08 & 0,40 \\
\hline Vandaele et al. (1996) & Portugal & 0,02 & 0,35 \\
\hline Vanderkerckhove et al. (1998) & Espanha & 0,157 & 0,133 \\
\hline Vanderkerckhove et al. (1998) & Portugal & 0,102 & 0,226 \\
\hline Vandekerckhove et al. (2000) & Espanha & 0,23 & 0,10 \\
\hline Nachtergaele et al. (2001) & Bélgica & 0,03 & 0,38 \\
\hline Vanwallmeghem et al. (2005) & Bélgica & 0,0578 & 0,152 \\
\hline Menendez-Duarte et al. (2007) & Espanha & 0,46 & 0,18 \\
\hline Knapen e Poesen (2010) & Bélgica & 0,05 & 0,40 \\
\hline Araújo (2011) & Brasil & 0,02 & 0,38 \\
\hline Stabile (2015) & Brasil & 0,064 & 0,084 \\
\hline
\end{tabular}

(*) Os valores de Menéndez-Duarte et al. (2007) e Araújo (2011) referem-se aos canais profundos.

Fonte: Adaptado de Torri e Poesen (2014). 
Ao propor um limiar a partir de desencadeamento das erosões deve-se considerar que existem diversos fatores que influenciam nos valores de " $a$ " e "- $b$ " e, consequentemente, na correlação entre os parâmetros A e S. Desta forma, várias considerações foram propostas pelos autores para melhorar o ajuste destes dados, dentre estes trabalhos cita-se o de Vanderkerckhove et al. (1998), que analisaram o limiar de desencadeamento para feições erosivas localizadas no sudeste da Espanha e no nordeste de Portugal. Os autores constataram que ao analisar as feições considerando características especificas como localização topográfica: vales (hollows) e encostas planas (straight slope), e direção das culturas agrícolas (perpendicular, paralela e direções combinadas) pode-se obter melhores resultados, quanto à correlação entre os parâmetros A e S. Isto ocorre porque tais aspectos influenciam nos mecanismos de escoamento superficial que propiciam o surgimento das feições, além disso, os melhores ajustes se refletem nos canais onde há concentração de fluxo.

Outra consideração importante foi observada no trabalho de Vanderkerckhove et al. (2000), que consideram que além das características de localização das feições e, tipo de cobertura vegetal, deve-se ponderar as questões relativas as características do solo, que influenciam nos mecanismos de escoamento superficial e subsuperficial. Estas características se refletem significativamente nos valores de declividade, que por sua vez condicionam diferentes tipos de processos geomorfológicos, como erosão hídrica e movimentos de massa (Figura 9).

Figura 9 - Limiares topográficos conforme os processos dominantes (Mar Mediterrâneo).

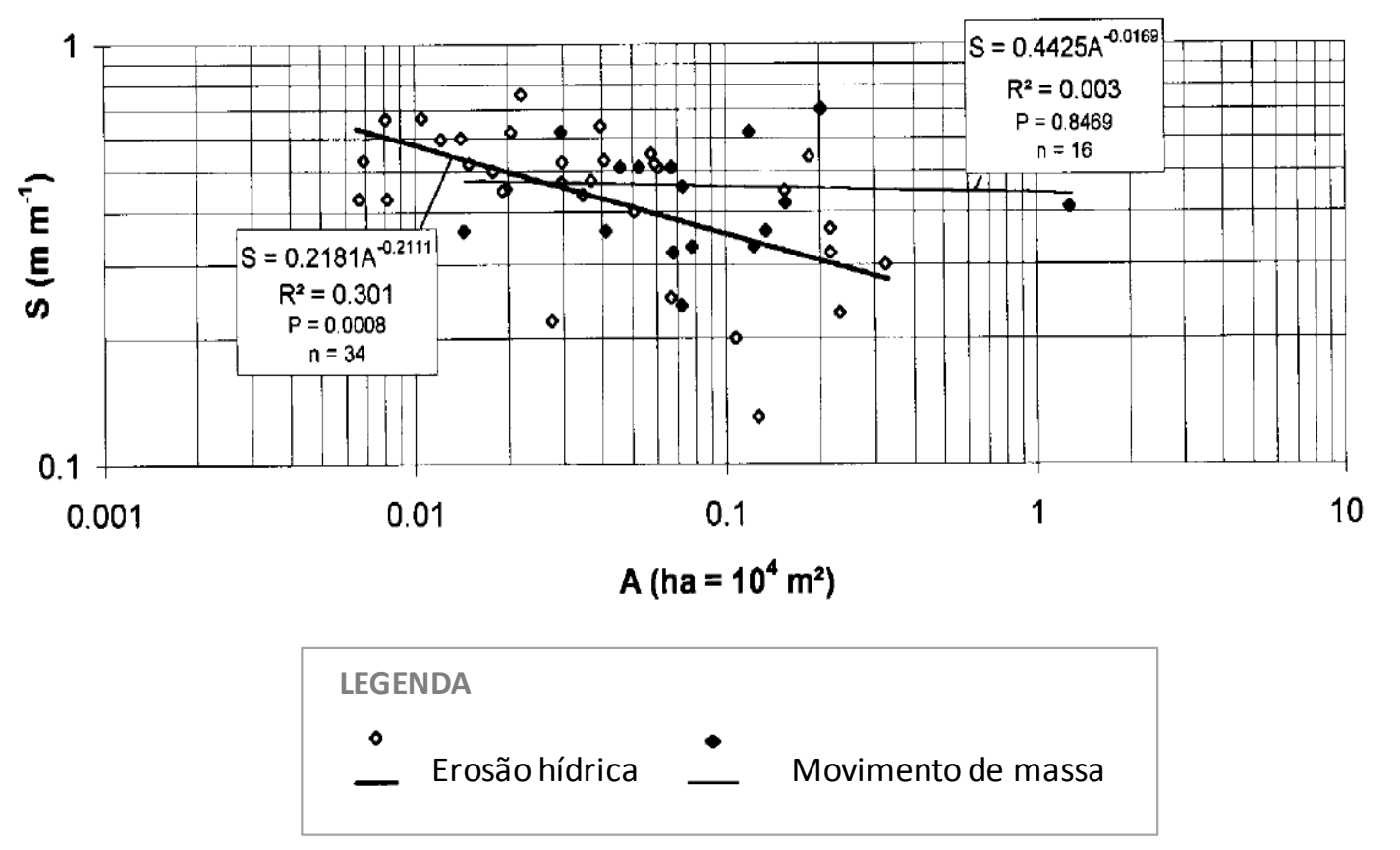

Fonte: Adaptado de Vandekerckhove et al. (2000). 
A análise dos limiares também pode ser realizada considerando a profundidade dos canais, como exemplo, cita-se o trabalho de Vanwallmeghem et al. (2005), desenvolvido na Bélgica. Por meio de levantamento de campo foram obtidas informações de comprimento, largura e profundidade das feições, e também os parâmetros área de contribuição e declividade das cabeceiras. Os limiares topográficos foram definidos para canais rasos $(<0,8 \mathrm{~m})$ e canais profundos $(>0,8 \mathrm{~m})$, conforme apresentado na Figura 10, observa-se que a diferença entre a posição dos limiares evidencia claramente que, o surgimento dos canais rasos e profundos ocorre em posições distintas da paisagem.

Figura 10 - Gráfico SxA para canais localizados na Bélgica.

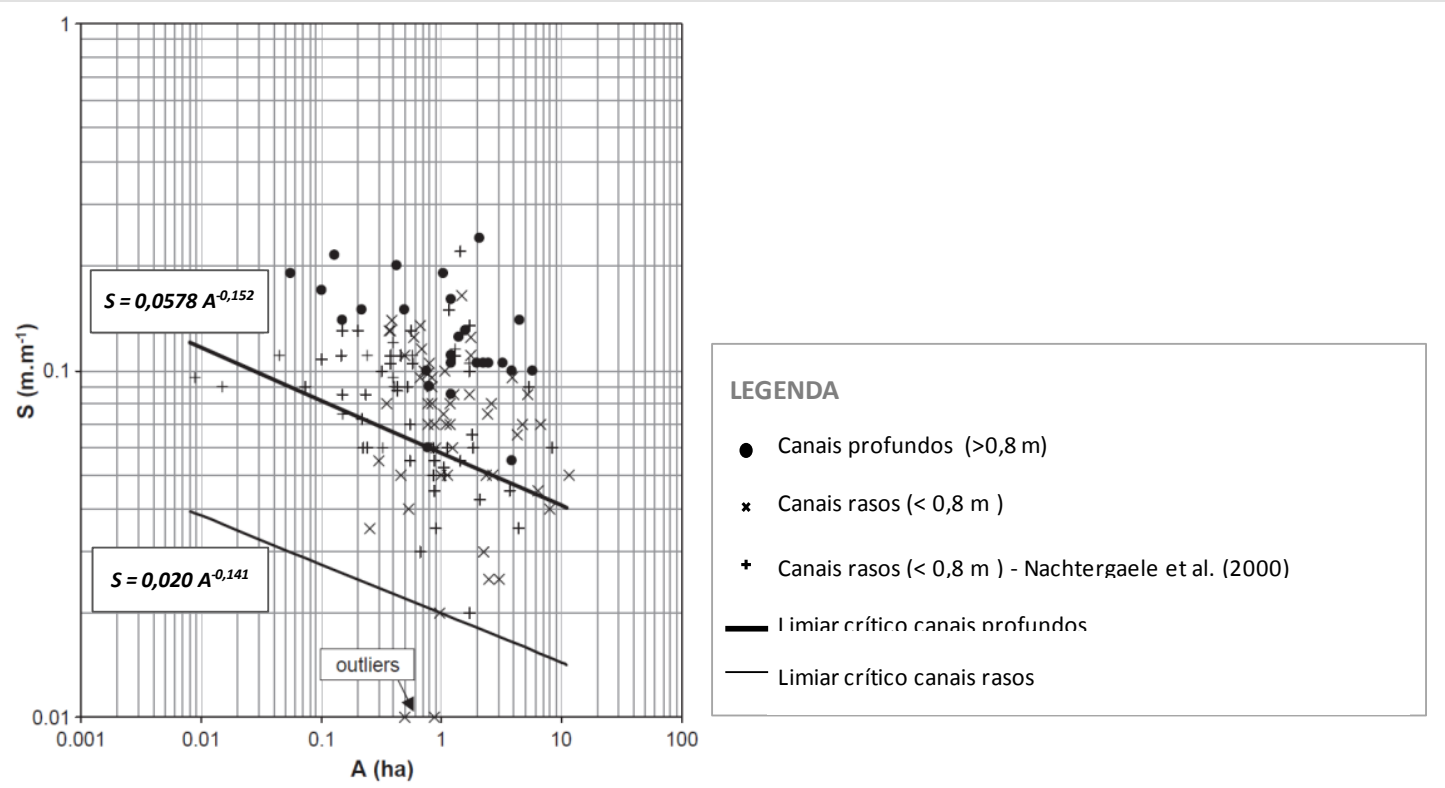

Fonte: Adaptado de Vanwallmeghem et al. (2005).

Menéndez-Duarte et al. (2007), também analisaram o limiar de desencadeamento das erosões considerando canais rasos $(<1 \mathrm{~m})$ e profundos $(>1 \mathrm{~m})$, localizados na Espanha. Para mapeamento destas feições foram utilizadas fotografias aéreas e levantamento de campo. Os resultados obtidos a partir da relação SxA mostraram que considerando uma área de 15 ha, a declividade necessária para o desencadeamento dos canais profundos é de $15,8^{\circ}$, e para os canais rasos 9,8 . Com base nas análises realizadas e na comparação com outros trabalhos, os autores concluíram que a declividade é o principal parâmetro morfométrico na determinação do limiar de desencadeamento das erosões. Portanto, devem ser utilizados parâmetros de entrada consistentes, que permitam a representação adequada dos processos analisados.

A elaboração do limiar de desencadeamento das erosões deve ser realizada considerando a localização das cabeceiras das feições, que por sua vez, se refletem nos 
parâmetros morfométricos. Segundo Montgomery e Dietrich (1994) o tamanho da área de contribuição tende a sofrer modificações devido às condições climáticas e a migração da cabeceira ao longo da encosta.

Gutiérrez et al. (2009) avaliaram por meio de ortofotos de diferentes datas (1945, 1956, 1989, 1998, 2002 e 2006) o avanço das cabeceiras das feições, e a partir destes dados determinaram os índices $\mathrm{S} x \mathrm{~A}$. Os autores observaram que as mudanças em termos de área das feições ocorrem em função das mudanças do uso e ocupação e também da remoção da cobertura vegetal. Em relação aos coeficientes do índice, " $a$ " $\mathrm{e}$ "- $b$ " as maiores variações foram no "a", que refletem as mudanças de uso e apresenta relação direta com as características do ambiente, como precipitação, solo e vegetação.

Destaca-se que, com base nas equações $\mathrm{S} x \mathrm{~A}$ obtidas, os autores citados elaboraram o mapa de áreas críticas em SIG, que representa a relação matricial entre o mapa de declividade e de área de drenagem. A Figura 11 apresenta o mapa para uma área da bacia de Parapuños, localizada na Espanha, e a equação utilizada para definição destas áreas. Estes mapas auxiliam a compreensão dos processos de evolução das feições e podem ser aplicados em conjunto com as técnicas de conservação do solo (GUTIÉRREZ et al., 2009)

Figura 11 - Mapa de áreas críticas (Sudoeste Espanha).

Fonte: Adaptado de Gutiérrez et al. (2009).

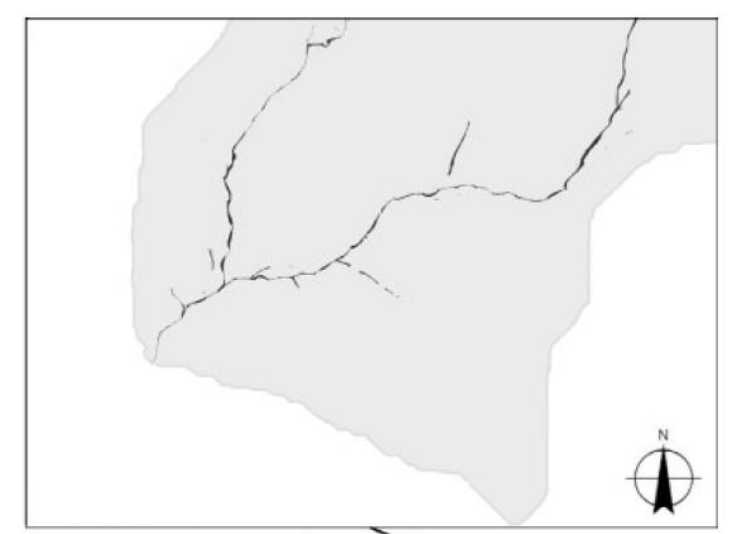

LEGENDA

Índice (2002 a 2006) $\rightarrow S=0.13 A^{-0.63}$

3 Áreas críticas $=S-\left(0.13 A^{-0.63}\right)>0$

Áreas críticas

Nazari Samani et al. (2009) fizeram duas análises importantes, a primeira delas foi estabelecer o limiar crítico considerando os processos que condicionam o surgimento dos canais, como escoamento superficial; e a segunda compreendeu a análise dos limiares com base no método utilizado para obtenção dos parâmetros A e S.

Assim como outros autores, Nazari Samani et al. (2009) verificaram que a análise integrada dos dados não favorece o ajuste dos parâmetros A e S, sendo, portanto, necessário 
considerar os fatores associados ao aparecimento das feições. Quanto ao método utilizado os limiares obtidos são semelhantes, portanto, quando não existe a possibilidade de realização de levantamento de campo a utilização de dados espaciais é uma alternativa eficaz. No entanto, a confiabilidade dos resultados depende da acurácia do modelo digital de elevação. A Figura 12 apresenta os dados obtidos pelos autores.

Figura 12 - Gráficos SxA para diferentes método de obtenção dos parâmetros.

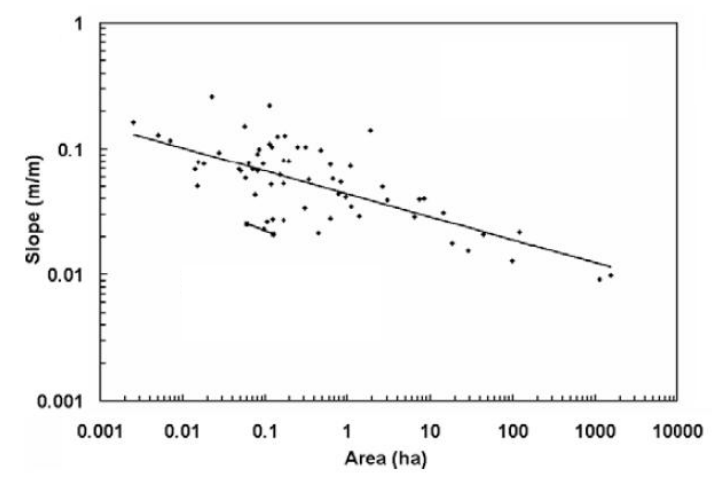

Mecanismo de iniciação: escoamento superficial

- Método: Modelo Digital de Elevação

$-R^{2}: 0,47$

- Índice: $S=0,0121 A^{-0,2624}$

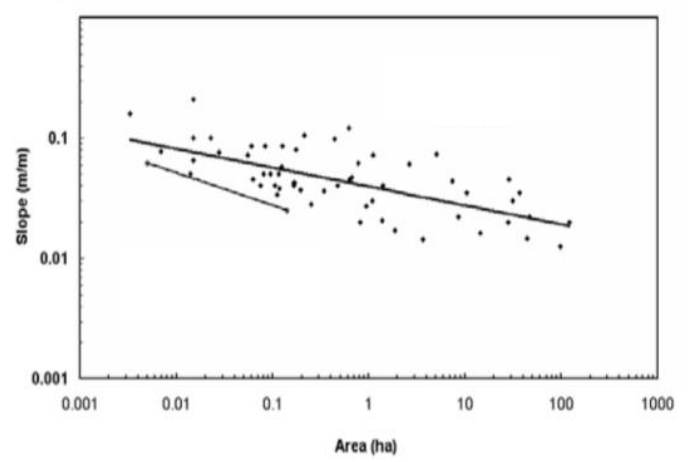

Mecanismo de iniciação: escoamento superficial

- Método: Mensuração em campo

$\boldsymbol{R}^{2}: 0,49$

- Indice: $S=0,0146 A^{-0,2726}$

Fonte: Adaptado de Nazari Samani et al. (2009).

No Brasil, destaca-se o trabalho de Araújo (2011), realizado na região de São Pedro SP, que propôs dois índices (I e II) considerando o estágio inicial das feições. O índice I é referente às cabeceiras das erosões identificadas por fotografia aérea, onde os canais analisados foram divididos em rasos $(<1 \mathrm{~m})$ e profundos $(>1 \mathrm{~m})$. No índice II, as áreas das cabeceiras das feições foram obtidas por fotografia aérea ortorretificada, em escala de 1:30.000, portanto neste índice foram consideradas apenas os canais profundos.

A Figura 13 apresenta o gráfico e os respectivos índices. Para o Índice I, adotando-se uma área de contribuição de $1000 \mathrm{~m}^{2}$, a declividade crítica para desencadeamento de erosões em canal raso foi de 3,55\% e para canais profundos 5,2 \%. Todavia para o Índice II, considerando apenas as erosões de grandes portes, para uma área de $1000 \mathrm{~m}^{2}$, a declividade crítica foi de $14 \%$.

Uma observação importante deste trabalho é que as retas que representam o limiar crítico para o desencadeamento das erosões foram obtidas de forma empírica, pois o autor não obteve um bom ajuste matemático dos pontos plotados no gráfico S $x$ A. No entanto, a partir da 
validação realizada foi possível constatar que os índices obtidos estão em conformidade com as características da área em estudo e, portanto, estão condizentes com os limiares de desencadeamento das erosões lineares (ARAÚJO, 2011).

Figura 13 - Gráfico SxA para canais localizados na região de São Pedro - SP.

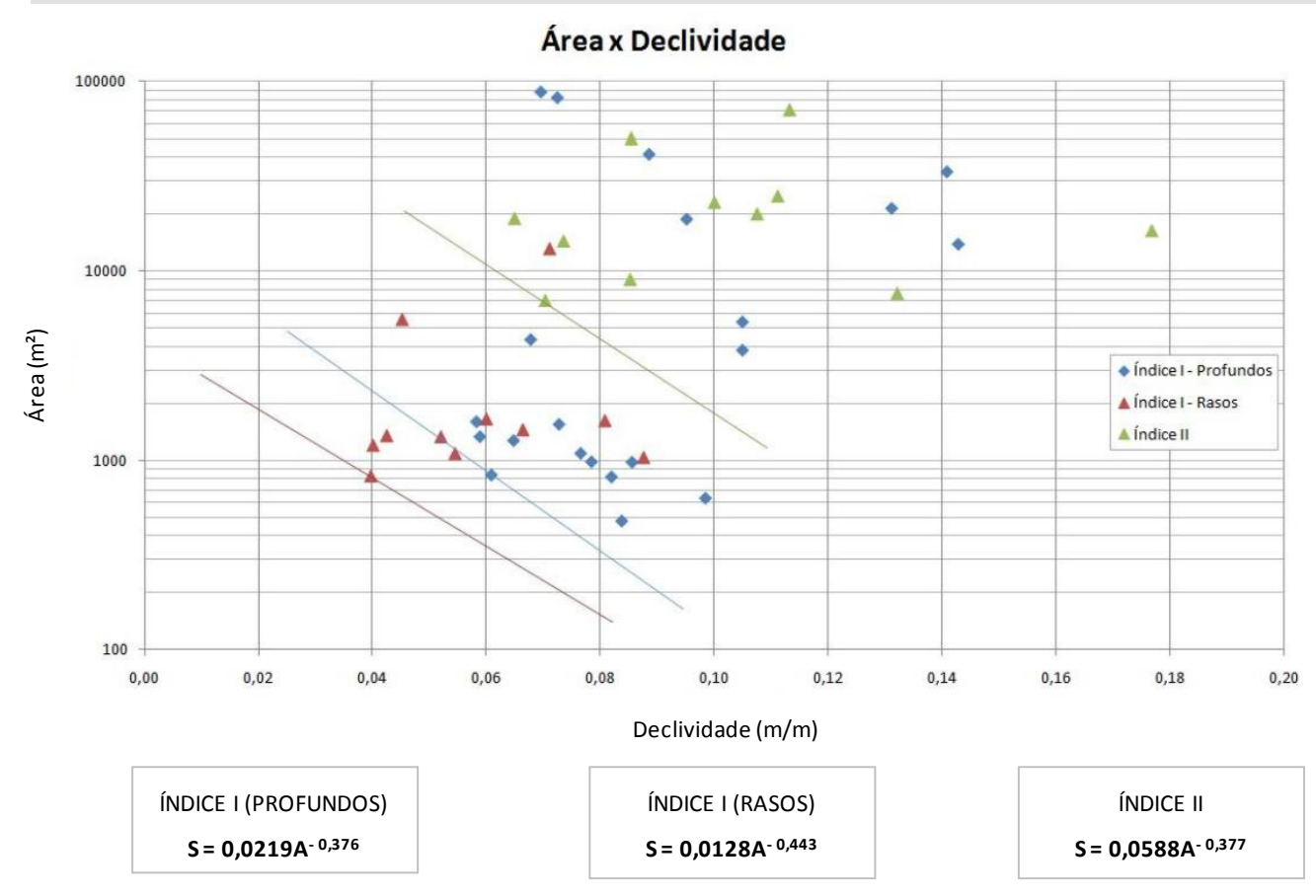

Fonte: Adaptado de Araújo (2011).

Outro trabalho desenvolvido no Brasil foi o de Stabile (2013), que avaliou os limiares críticos para o desencadeamento de erosões lineares localizadas em Piratinga (SP). A mensuração da declividade (S) foi realizada de duas maneiras, em campo utilizando um pantômetro, e através do modelo digital do terreno (MDT), no qual foram obtidas também as áreas de contribuição. Para proposição dos limiares críticos as feições foram divididas em dois grupos, considerando o condicionamento antrópico. A Figura 14 apresenta um dos gráficos obtidos pelo autor.

Em relação à mensuração da declividade o autor concluiu que o método utilizado reflete significativamente nos valores deste parâmetro, desta forma, em função da baixa correlação obtida com os dados coletados em campo, optou-se pela utilização do modelo digital do terreno $(10 \times 10 \mathrm{~m})$, pois apresentou melhor precisão.

Quanto à relação entre $\mathrm{A} \mathrm{e} \mathrm{S}$, constatou que coeficientes " $a$ " e "- $b$ " estão condizentes com os processos analisados, no entanto, a localização de alguns pontos abaixo do limiar crítico indica que o desencadeamento destes canais está relacionado não só com parâmetros 
morfométricos, mas também com fatores antrópicos, portanto estas feições não existiriam em condições normais, e por isso sua análise não deve ser fundamentada apenas em aspectos topográficos (STABILE, 2013).

Figura 14 - Gráfico SxA para canais localizados em Piratinga - SP.

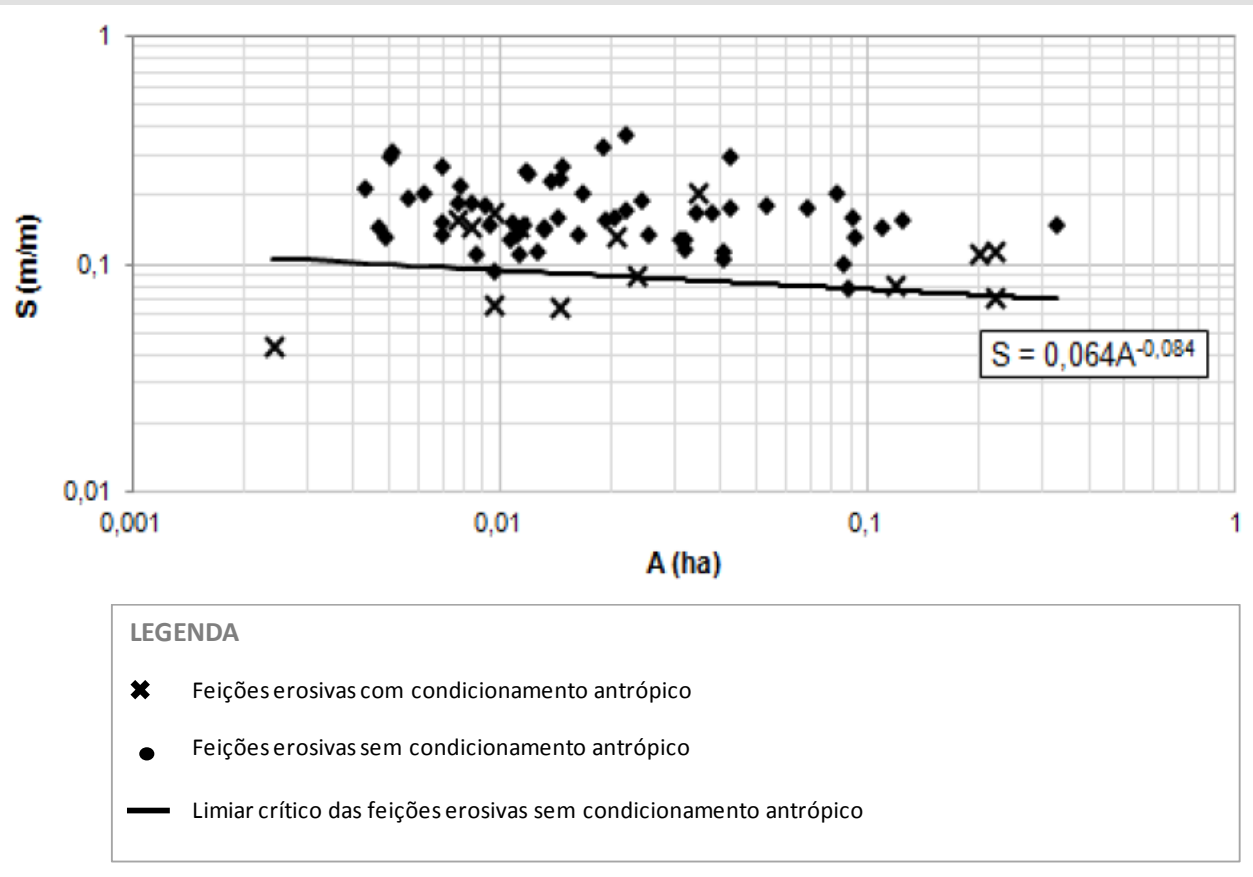

Fonte: Adaptado de Stabile, 2013.

\subsubsection{Limiar para representação das áreas instáveis}

Considerando a abordagem proposta por Patton e Schumm (1975), Dietrich et al. (1992) e Montgomery e Dietrich (1994), desenvolveram um modelo analítico para representar as áreas de instabilidade na paisagem decorrentes de processos erosivos intensos. O modelo tem como base três equações que descrevem os limiares de saturação do solo; de erosão por escoamento superficial; e deslizamento.

De acordo com Dietrich et al. (1992) o método proposto tem como base os modelos numéricos de evolução da paisagem e as proposições feitas por outros autores como Horton (1945); O’Loughlin (1986); Moore et al. (1988); Beven e Kirbby (1979). Para determinar as equações dos limiares, os autores fizeram algumas considerações: o escoamento subsuperficial é paralelo à superfície da encosta; a condutividade hidráulica, a trasnmissividade e as propriedades que determinam a resistência do solo à erosão são espacialmente constantes. 
Desta maneira foram propostas três equações para prever as zonas de saturação na paisagem, considerando características geomorfológicas (declividade e área de contribuição da encosta), natureza do solo e processos hidrológicos, como escoamento superficial hortoniano e escoamento superficial por saturação.

\subsubsection{Limiar de saturação do solo}

Considerando $a$ como o índice geomorfológico (área de contribuição por unidade de contorno); R, escoamento lateral subsuperficial do solo saturado; $\mathrm{T}$, transmissividade; e $\mathrm{M} \mathrm{o}$ gradiente hidráulico, o limiar de saturação do solo, pode ser descrito a partir da Equação 5. Segundo Dietrich et al. (1992) o solo apresenta uma condição saturada quando o valor da área de contribuição for maior ou igual aos parâmetros descritos no lado direito da equação.

$$
a \geq \frac{\mathrm{T}}{\mathrm{R}} \cdot \mathrm{M}
$$

É importante ressaltar que para equacionar este limiar os autores consideraram a definição proposta por O’Loughlin (1986), que estabeleceu um critério para analisar as áreas de saturação a partir do comprimento da área de contorno (Figura 15). Segundo o autor o índice geomorfológico (a) é definido como a relação entre área de contribuição e unidade de contorno.

Figura 15 - Representação do índice geomorfológico.

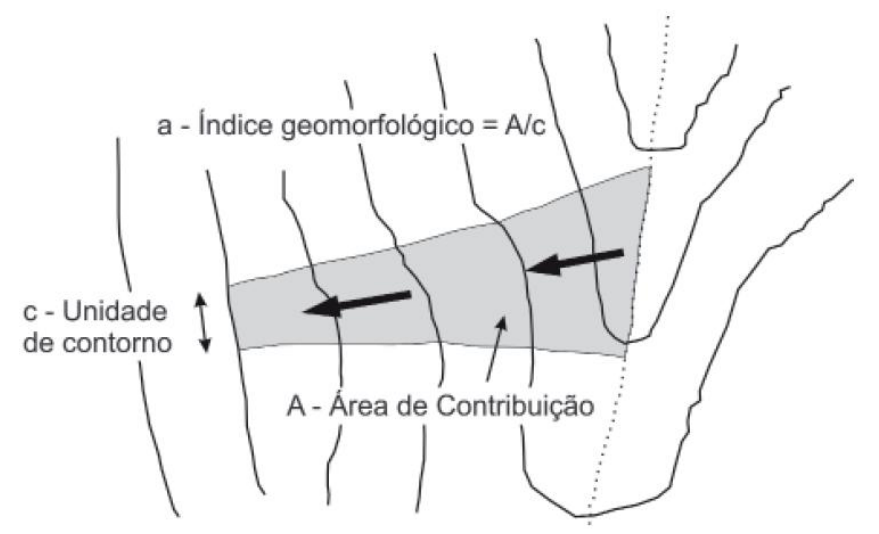

Fonte: Vestena e Kobiyama (2014).

\subsubsection{Limiar de erosão por escoamento superficial}

Para determinar este limiar Dietrich et al. (1992) utilizaram como base as equações que regem o escoamento superficial hortoniano, como vazão, velocidade do escoamento e tensão crítica. 
Os autores verificaram que o inicio dos canais de erosão, especificamente das ravinas, ocorre quando a tensão de cisalhamento crítica é excedida e, que o escoamento superficial por saturação ocorrerá quando o volume de precipitado for maior que a capacidade de infiltração. Desta forma, a área crítica para ocorrência da erosão por escoamento superficial por saturação pode ser definida a partir da Equação 6.

$$
\mathrm{a}_{\mathrm{cs}}=\frac{2 \cdot \tau_{\mathrm{c}}^{3}}{k \cdot v \cdot \rho_{a}^{3} \cdot g^{2} \cdot R \cdot M^{2}}+\frac{\mathrm{T} \cdot \mathrm{M}}{\mathrm{R}}
$$

Onde:

- $\quad \mathrm{a}_{\mathrm{cs}}=$ área crítica por unidade de contorno necessária para ocorrência de erosão por escoamento superficial;

- $\tau_{\mathrm{c}}=$ tensão de cisalhamento crítica $\left(\mathrm{N} / \mathrm{m}^{2}\right)$;

- $\quad \mathrm{k}=$ constante ligada à geometria da superfície (adimensional);

- $\mathrm{v}=$ viscosidade cinemática $\left(\mathrm{m}^{2} / \mathrm{s}\right)$;

- $\quad \rho_{\mathrm{a}}=$ densidade da água $\left(1000 \mathrm{~kg} / \mathrm{m}^{3}\right)$;

- $\mathrm{g}=$ aceleração da gravidade $\left(9,8 \mathrm{~m} / \mathrm{s}^{2}\right)$;

- $\mathrm{R}=$ precipitação não interceptada sobre área $(\mathrm{m} / \mathrm{s})$;

- $\mathrm{M}=$ declividade do terreno $(\mathrm{m} / \mathrm{m})$;

\subsubsection{Limiar de deslizamento}

Para determinar a equação que rege o limiar de deslizamento, Dietrich et al. (1992) consideraram dados de vazão, condições de fluxo e condutividade hidráulica, e também os modelos de instabilidade da vertente infinita e hidrologia de vertente. A Equação 7 determina a área crítica para ocorrência de erosões por deslizamentos.

$$
a_{c d}=2\left(1-\frac{M}{\tan \varnothing}\right) \cdot \frac{T \cdot M}{R}
$$

Onde:

- $\mathrm{a}_{\mathrm{cd}}=$ área crítica para ocorrência de erosões por deslizamentos;

- $\quad \varnothing=$ ângulo de atrito (grau);

A partir da teoria dos limiares dos processos erosivos foi possível elaborar um gráfico que representa os limites espaciais entre os diferentes tipos de erosão que podem ocorrer em uma bacia hidrográfica. Desta forma Montgomery e Dietrich (1994) representaram 
graficamente a relação entre área de contribuição e declividade, considerando os diversos processos hidrológicos que ocorrem na vertente (Figura 16).

Figura 16 - Limiares críticos na paisagem.

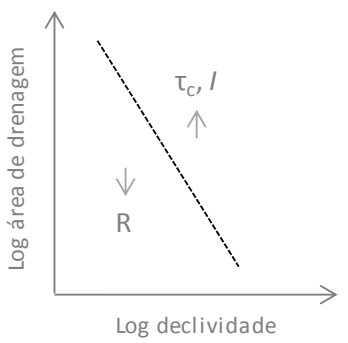

ESCOAMENTO SUPERFICIAL HORTONIANO TURBULENTO

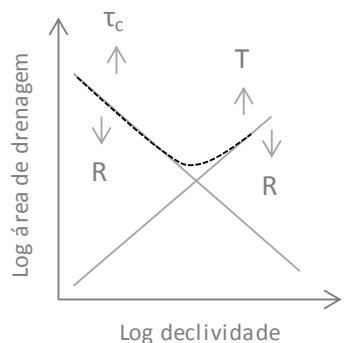

ESCOAMENTO SUPERFICIAL PORSATURAÇÃO

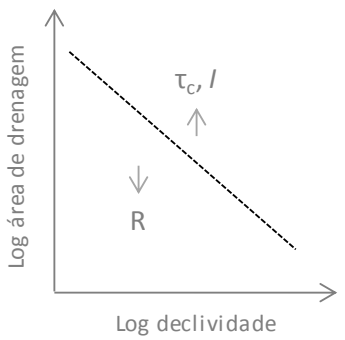

ESCOAMENTOSUPERFICIAL HORTONIANO LAMINAR

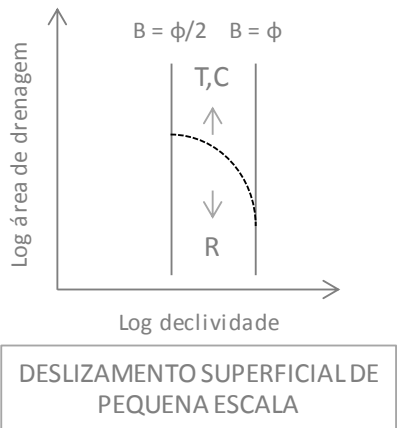

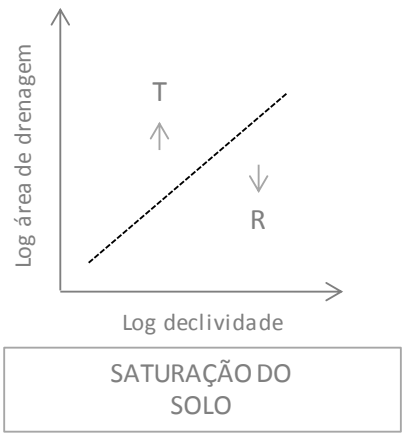

LEGENDA

(R) INTENSIDADE DA CHUVA

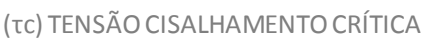

(I) CAPACIDADE DE INFILTRAÇÃO

(T) TRANSMISSIVIDADE

(C) COESÃO

(ф) ÂNGULO INTERNO DE FRICÇÃO

Fonte: Adaptado de Montgomery e Dietrich (1994).

Da junção dos gráficos ilustrados na Figura 16, resulta no gráfico da Figura 17 que relaciona área de drenagem e declividade e os limiares que representam as áreas de instabilidade na paisagem.

Figura 17 - Limiares de saturação do solo, de erosão por escoamento superficial, e deslizamento.

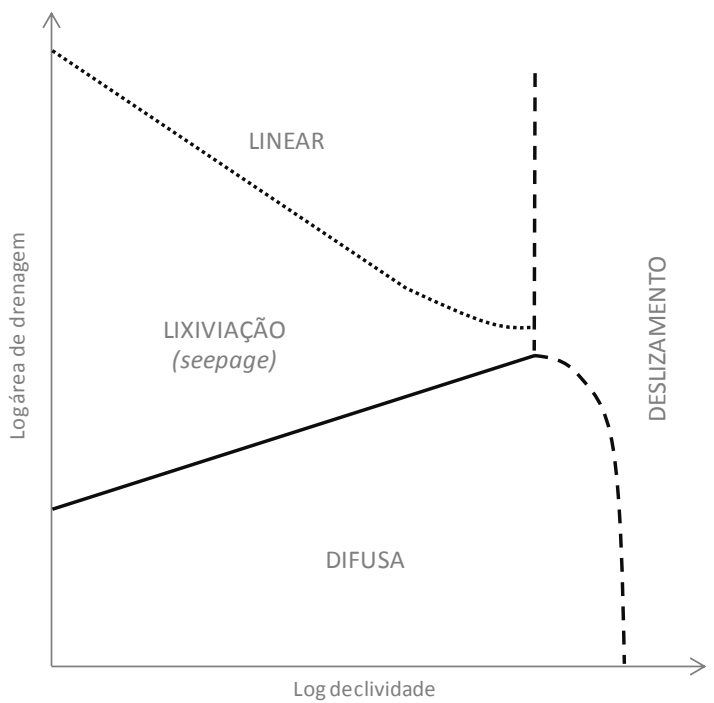

LEGENDA

- - - - L LIMIARDEDESLIZAMENTO

LIMIARDESATURAÇÃO

Fonte: Adaptado de Montgomery e Dietrich (1994). 
O modelo proposto por Montgomery e Dietrich (1994) tem como base a relação entre área de contribuição (A) $x$ declividade (S), no entanto o gráfico proposto por Patton e Schumm (1975) permite a representação apenas do limiar critico que condiciona os processos erosivos, com base nos parâmetros morfométricos. Enquanto que, o gráfico destes autores representa os limiares críticos de três processos distintos, que por sua vez estão relacionados com as zonas instáveis da paisagem, que ocorrem em função de parâmetros geomorfológicos, hidráulicos e geotécnicos.

No Brasil, considerando as equações descritas por Dietrich et al. (1992), Santos (2001) desenvolveu o mapeamento e identificação dos limiares dos processos erosivos na bacia hidrográfica do Rio Pequeno, localizada na região de Curitiba. Correlacionando as equações, parâmetros geotécnicos e hidrológicos do solo e, informações espaciais (índice geomorfológico e declividade), o autor realizou a simulação dos diferentes processos erosivos que ocorrem naquela área.

Grando (2011) também estabeleceu os limiares dos processos erosivos em uma microbacia hidrográfica localizada na região do Planalto Norte do estado de Santa Catarina, utilizando também a metodologia de Montgomery e Dietrich (1994). A autora buscou identificar as alterações que levaram ao desencadeamento dos processos erosivos correlacionando com parâmetros geotécnicos e hídricos do solo.

Outro trabalho desenvolvido neste contexto foi o de Vestena e Kobiyama (2014) que realizaram a identificação e mapeamento dos processos erosivos na bacia hidrográfica do Rio Caeté localizada em Alfredo Wagner - SC. Para determinar espacialmente os diferentes processos os autores consideraram a metodologia proposta por Dietrich et al. (1992) e também elaboraram uma carta de diagnóstico ambiental, correlacionando as formas de uso e ocupação com os processos erosivos.

\subsection{Mapeamento geotécnico}

O mapeamento geotécnico compreende os processos que visam o levantamento, caracterização, classificação, avaliação e análise de atributos relacionados ao meio físico, como geologia, hidrogeologia, hidrologia, entre outros, que por sua vez, serão manipulados, correlacionados, interpretados e representados em mapas e cartas geotécnicas (ZUQUETTE, 1987). 
Segundo Sobreira e Souza (2012), a cartografia geotécnica, como um conjunto de produtos cartográficos que retratam os atributos do meio físico (solos e rochas), deve ter por finalidade a avaliação das limitações e potencialidades de uma determinada área, frente às diferentes formas de ocupação.

A elaboração de mapas de inventário; mapas de suscetibilidade e riscos; mapas para planejamento e uso de solo, deve ter como base o conhecimento de aspectos relacionados ao meio físico. No entanto, a elaboração destes mapas e cartas deve avaliar também a variação destes aspectos com o tempo, onde serão avaliados, por exemplo, a intensidade dos fatores desencadeadores e a interferência antrópica (SOBREIRA, 2004).

Além disso, de acordo com Pejon e Zuquette (1995), a seleção dos atributos a serem utilizados na elaboração de cartas e mapas geotécnicos deve estar intrinsecamente relacionada com a escala de trabalho adotada, considerando principalmente as possíveis inter-relações existentes entre estes dados. Segundo os autores, estas condições determinam a eficiência e qualidade dos produtos cartográficos obtidos.

Conforme citado por Zuquette e Gandolfi (2004) existem diversas metodologias para elaboração de mapas e cartas geotécnicas: IAEG (International Association of Engineering Geology); Francesa (SANEJOUAND, 1972); ARDA (Sistema de Geoinformação do Inventário de Terras do Canadá); IG-UFRJ (BARROSO et al., 1993); IPT (PRANDINI et al., 1995); EESC/USP (ZUQUETTE, 1987 e 1993), entre outras.

Dentre estas se destaca a metodologia da EESC/USP (ZUQUETTE, 1987 e 1993) que surgiu em função da necessidade de adaptação às condições socioeconômicas e climáticas do Brasil. O autor propõe que o trabalho seja realizado em três fases: a primeira consiste na definição do problema a ser investigado; a segunda compreende a divisão da área em unidades homogêneas em função das propriedades e das relações entre os atributos; e por fim, se realiza a comprovação da hipótese, por meio de ensaios e tratamento físico. Os documentos cartográficos resultantes desta metodologia podem ser classificados em quatro tipos: mapas básicos fundamentais; mapas básicos opcionais; mapas auxiliares e cartas derivadas ou interpretativas (Figura 18). 
Figura 18 - Documentos cartográficos produzidos pelo mapeamento geotécnico.

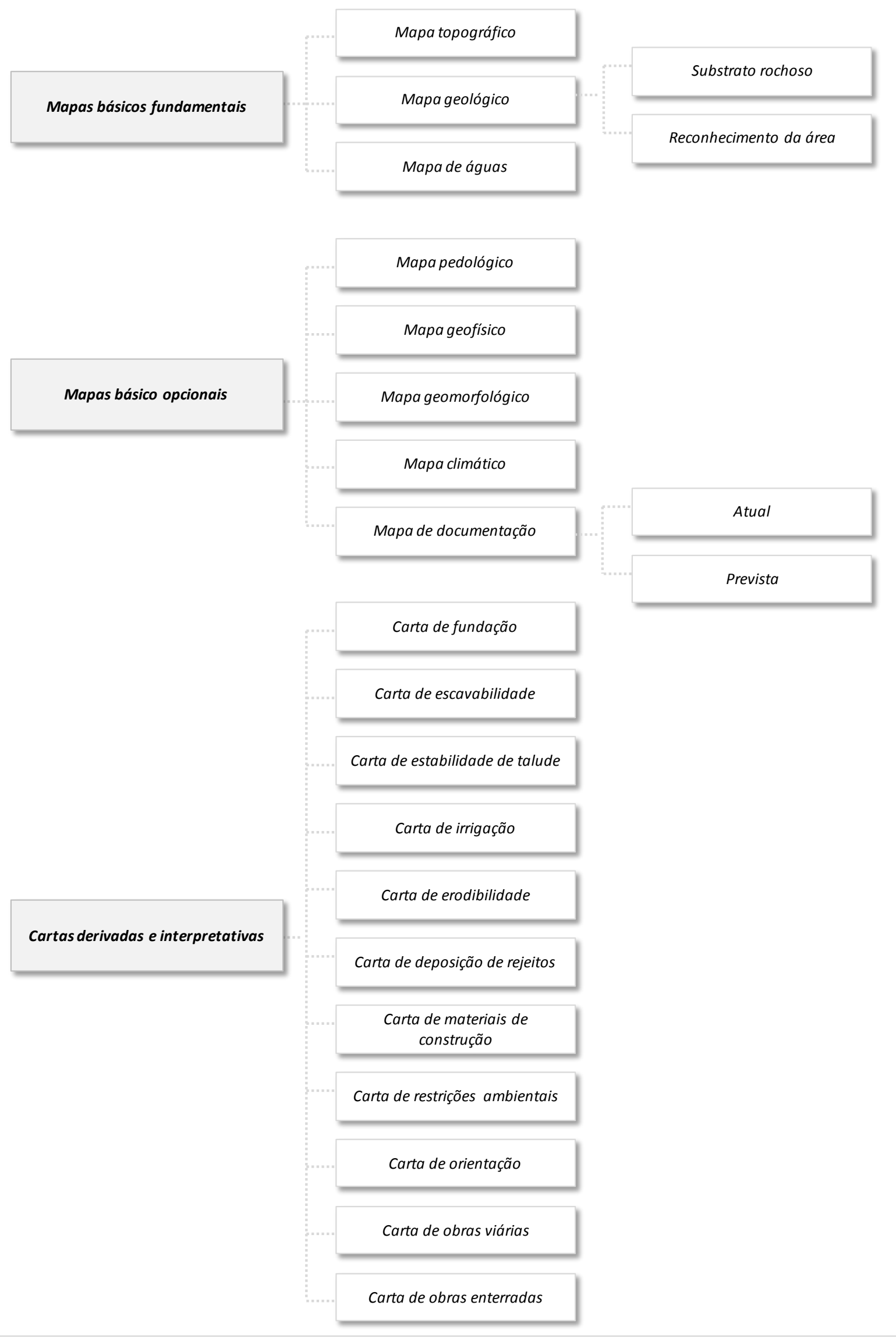

Fonte: Adaptado de Gomes (2002). 
Diniz (2012) apresenta uma classificação para as cartas geotécnicas segundo sua finalidade: planejamento urbano e regional; avaliação do meio físico; e viabilidade de implantação de projetos de infraestrutura e empreendimentos. Quando a finalidade envolve a avaliação do meio físico, consideram-se neste caso as cartas de suscetibilidades e riscos geológicos existentes como erosão, inundação, escorregamentos, sismos, entre outros.

A carta de potencial à erosão, segundo Pejon e Zuquette (1995), deve ser elaborada a partir da interpretação e sobreposição de planos de informações da área a ser mapeada. Para cada um dos atributos considerados são atribuídos pesos em função de sua importância, resultando em um produto com novos limites redefinidos, indicando as áreas mais ou menos suscetíveis a ocorrência de processos erosivos.

Zuquette (1987) cita os atributos que devem ser considerados em uma carta geotécnica de avaliação dos processos erosivos: natureza dos materiais (propriedades geotécnicas); relevo; cobertura vegetal; fatores climáticos; ação antrópica; e ação da água. Segundo o autor, o produto cartográfico obtido deverá representar à alta, média ou baixa susceptibilidade dos materiais constituintes quanto à ocorrência de processos erosivos.

Gomes (2002) realizou o mapeamento geológico-goetécnico das feições erosivas concentradas na Bacia do Córrego do Meio, na escala de 1:20.000. Os atributos considerados pela autora (Figura 19) foram inicialmente agrupados de maneira hierárquica, atribuindo-se em seguida os respectivos valores conforme o grau de importância de cada um deles. As classes de suscetibilidade estabelecidas foram: muito pouco suscetível; pouco suscetível; moderadamente suscetível; suscetível; altamente suscetível.

Figura 19 - Atributos do meio físico associados à erosão.

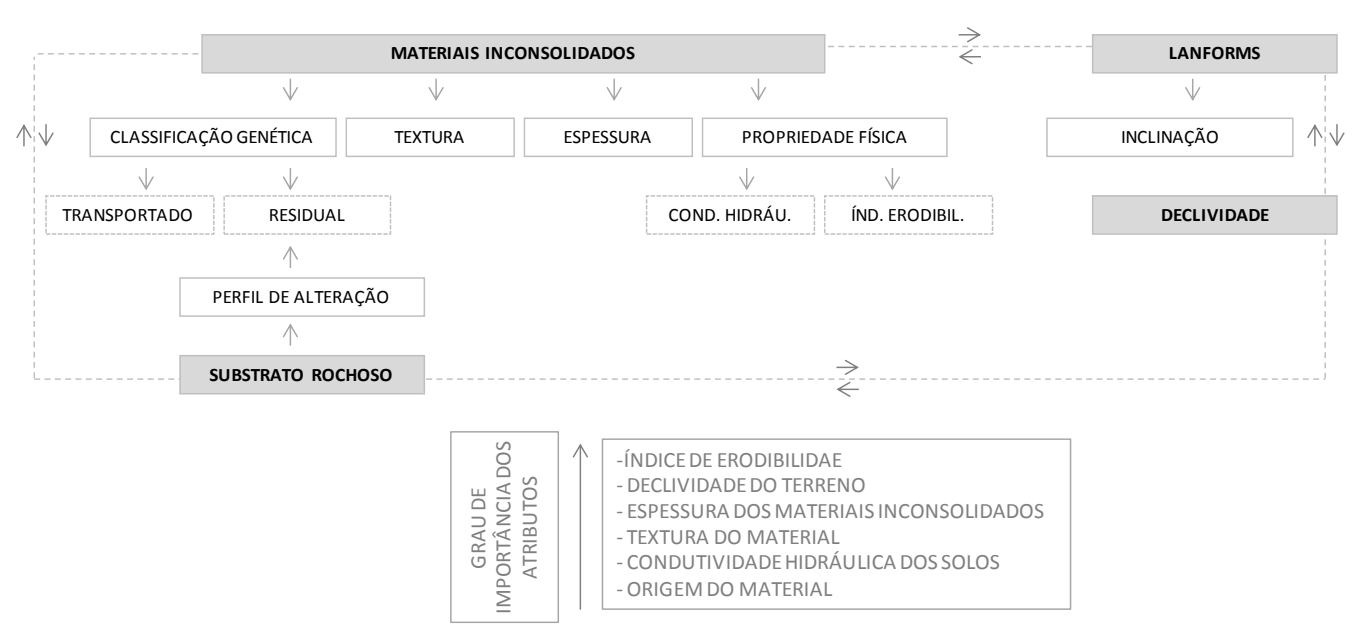

Fonte: Adaptado de Gomes (2002). 
Magri (2013) elaborou a Carta de Suscetibilidade à Erosão da Bacia Hidrográfica do Médio Rio Grande (1:50.000) a partir da interpolação dos seguintes planos de informação: substrato rochoso; formas do terreno; materiais inconsolidados e declividade. Inicialmente, estes dados foram analisados individualmente, avaliando a importância de cada um deles na ocorrência de processos erosivo, em seguida foram analisados em conjunto, através de matrizes de comparação pareada (AHP). As áreas mapeadas pelo autor foram classificadas em muito baixa, baixa, média, alta e muito alta suscetibilidade à erosão.

Outro exemplo de mapeamento geotécnico, aplicado ao estudo de processos erosivos, foi o trabalho desenvolvido por Zuquette et al. (1995) que realizaram o mapeamento geotécnico da cidade de Franca (SP) na escala de 1:25.000. Utilizando atributos do meio físico como declividade; forma e comprimento da encosta; propriedades geotécnicas dos materiais incosolidados; litologia; profundidade do nível de água; escoamento superficial e inventário de feições erosivas, os autores elaboraram a carta de risco à erosão, que resultou em quatro unidades, com diferentes níveis de risco. A carta geotécnica foi utilizada também para orientar ações de prevenção e recuperação das erosões, orientando desta forma o local para instalação das obras e os processos de ocupação.

Netto e Sobreira (2006) mapearam os processos erosivos lineares na Bacia Hidrográfica do Ribeirão Carioca e elaboraram o Mapa Cadastral de Processos Erosivos (1:25.000), que representava a distribuição das feições erosivas na área de estudo e sua classificação quanto ao grau de desenvolvimento. Desta maneira, foi possível não só quantificar os processos como também analisar sua distribuição espacial.

\subsection{Geoprocessamento como ferramenta de auxílio}

O geoprocessamento é uma geotecnologia, que atualmente tem beneficiado diversas pesquisas cientificas que envolvem, por exemplo, a avaliação do meio físico, gestão e o planejamento ambiental, e pode ser definido como um conjunto de técnicas, métodos e conceitos, que operam sobre uma base de dados geo-orientados (XAVIER DA SILVA, 2009).

Segundo Rodrigues (1990), o geoprocessamento constitui um conjunto de tecnologias que permitem a aquisição e análise de informações espaciais, onde os resultados obtidos poderão ser aplicados em diversos trabalhos que tenham como escopo à representação espacial de diversos atributos, como por exemplo, dados do meio físico (geologia, hidrologia, entre outros). 
Assim, o termo geoprocessamento pode ser definido como a aplicação de técnicas computacionais denominadas Sistema de Informação Geográfica (SIG), para tratamento de informações geográficas, visando à realização de análises complexas, integração de dados; e criação de banco de dados georreferenciado (CÂMARA; MEDEIROS, 1998).

O geoprocessamento tem contribuído fortemente para o desenvolvimento da cartografia geotécnica, principalmente na execução de determinadas atividades como compilação de dados existentes; elaboração do banco de dados; processamento de dados de sensoriamento remoto; manipulação de dados pontuais; modelos numéricos do terreno e cartas (SOUZA; GANDOLFI, 1993).

Câmara e Medeiros (1998) citam alguns exemplos de operações e aplicações do geoprocessamento: classificação de imagens (áreas de floresta); análise espacial e elaboração de carta de declividade (áreas agrícolas); visualização em 3D (análise geológica e geomorfológica); e consulta espacial (estudos urbanos e regionais), entre outros.

Diversos softwares de geoprocessamento têm sido utilizados, Celestino e Diniz (1998) citam alguns deles, descritos na Tabela 10.

Tabela 10 - Softwares de geoprocessamento.

\begin{tabular}{c|c|c}
\hline Software & Tipo & Distribuidor \\
\hline ArcGIS & SIG & ESRI \\
\hline IDRISI & SIG & Centro de Recursos Idrisi \\
\hline MAPINFO & SIG & GEOGRAPH \\
\hline SPRING & SIG & INPE \\
\hline AutoCAD MAP & CAD/SIG & GISOFT \\
\hline ENVI & Processamento de Imagens & SISGRAPH \\
\hline IMAGER & Processamento de Imagens & INPE \\
\hline SITIM/SGI & Processamento de Imagens & \\
\hline
\end{tabular}

Fonte: Adaptado de Celestino e Diniz (1998).

O ArcGIS desenvolvido pela Esri ${ }^{\circledR}$, tem sido bastante utilizado em estudos que visam a análise espacial, especificamente na análise hidrológica; análise geoestatística; processamento de dados georreferenciados; elaboração de produtos cartográficos; composição de banco de dados, entre outros. Este software é composto basicamente por três ambientes de trabalho: ArcCatalog utilizado para gerenciar os dados; ArcMap que realiza todas as atividades referentes a manipulação de dados e; ArcToolbox que permite a conversão e aplicação de técnicas de geoprocessamento (MITCHELL, 1999). 


\subsubsection{Sistema de informação geográfica $(S I G)$}

O SIG é uma ferramenta tecnológica que surgiu recentemente a partir da evolução da engenharia de computação. Esta ferramenta tem auxiliado diversos profissionais que buscam compreender a Terra, em seus diversos sistemas ambientais. Desta forma, o SIG tem sido utilizado em trabalhos de gestão ambiental, avaliação de impacto ambiental, análise de riscos ambientais, atividades de monitoramento entre outros (AUGUSTO FILHO, 2013).

O SIG consiste em um “conjunto composto por computador, programas e dados geográficos com capacidade de capturar, armazenar, atualizar, analisar e apresentar todas as formas de informações geograficamente referenciadas" (ESRI, 1997 apud AUGUSTO FILHO, 2013). A Figura 20 apresenta a arquitetura básica de um SIG.

Figura 20 - Estrutura de um SIG.

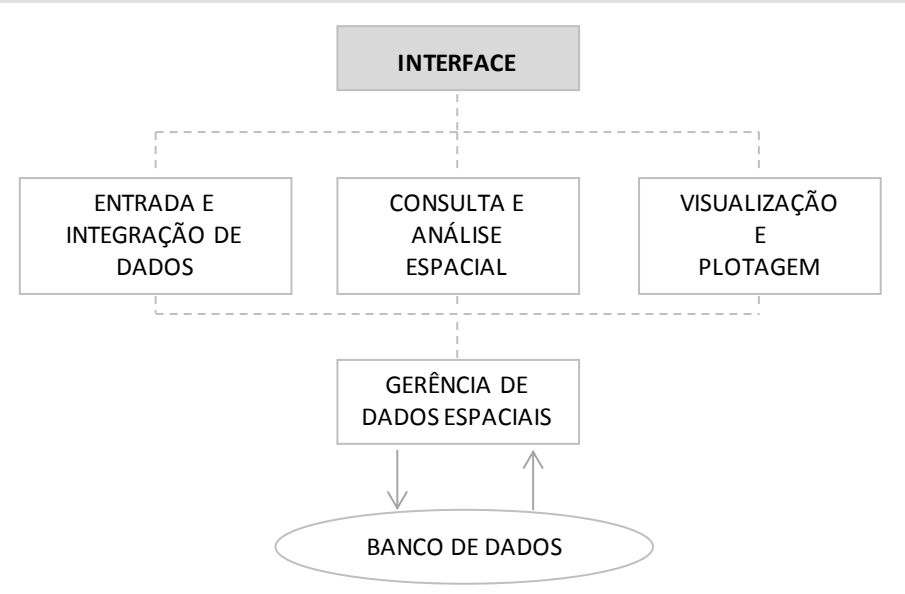

Fonte: Adaptado de Câmara e Medeiros (1998).

De acordo com Fitz (2008), o SIG consiste em um conjunto de sistemas associados, compostos por programas com diversos módulos que, por sua vez, podem compor outros sistemas independentes, e possui basicamente quatro funções: aquisição e edição de dados; gerenciamento de banco de dados; análise geográfica e representação de dados.

Existem duas maneiras de representar os dados espaciais no SIG, formato vetorial ou matricial. No vetorial os elementos gráficos são representados por pontos, linhas e polígonos, enquanto que no formato matricial todo o espaço é representado com uma matriz composta por linhas e colunas, onde cada célula possui um valor referente ao atributo analisado, e pode ser acessada a partir de suas coordenadas (CÂMARA; MEDEIROS, 1998).

Segundo Sobreira (2004), a utilização dos sistemas de informações geográficas, advindo da evolução da cartografia, possibilitou o armazenamento, tratamento e análise de um 
volume maior de dados, favorecendo a elaboração de cartas de suscetibilidade, vulnerabilidade e avaliação de riscos existentes, contribuindo de forma significativa para o desenvolvimento da cartográfica geotécnica, como um todo.

De acordo com Souza e Celestino (2004), a principal vantagem do SIG consiste na sua capacidade de realizar análises complexas, por meio da integração de dados espaciais em uma única base de dados. Além disso, o uso do SIG permite a manipulação de dados espaciais e a realização de diversas operações matemáticas, desta forma os mapas podem ser elaborados a partir de diversos planos de informação, integrados em uma mesma escala, que por sua vez, vão permitir a elaboração de cartas derivadas.

Celestino e Diniz (1998) citam alguns dos produtos que podem ser obtidos a partir do uso do SIG, no âmbito da geologia de engenharia: cartografia digital; modelagem digital de terrenos; automatização de cartas de declividade; diagnóstico do meio físico; gerenciamento de banco de dados geológico-geotécnico por unidades de terreno, municípios e bacias hidrográficas; avaliação geotécnica com diferentes objetivos; integração de planos de informação para elaboração de zoneamentos ou cartas interpretativas.

\subsubsection{Sensoriamento remoto}

O termo sensoriamento remoto é utilizado, de forma mais restrita, para designar os métodos eletromagnéticos usados na identificação e caracterização de objetos. Em outras palavras e de uma maneira mais ampla, o sensoriamento remoto pode ser definido como a tecnologia utilizada na detecção de objetos através de aviões e satélites, ou seja, sem que exista contato físico (GARCIA, 1982).

Novo (1992) define sensoriamento remoto como a aplicação de sensores para obter informações, seja de objetos ou fenômenos, sem o contato direto, uma vez que os sensores são instrumentos capacitados para coletar, converter e apresentar a energia proveniente do objeto de maneira adequada para o usuário. Desta forma, o sensoriamento remoto permite analisar as interações entre radiação eletromagnética e os componentes constituintes do planeta Terra.

De acordo com Augusto Filho (2013), o sistema sensor, que permite a conversão da energia eletromagnética, pode ser classificado como ativo ou passivo. O sistema ativo, como os radares, produz sua própria radiação; enquanto que os passivos como sistemas fotográficos, detectam a energia solar refletida ou emitida pelos alvos na superfície terrestre. Além disso, 
os sensores são caracterizados quanto às resoluções espaciais, espectral, radiométrica e temporal.

A resolução espacial consiste na capacidade do sensor de identificar os objetos, ou seja, a menor distância entre o objeto e o sensor; a resolução espectral é caracterizada pelo número de bandas espectrais e pela largura do comprimento de onda; a resolução radiométrica de um sensor refere-se ao número de níveis digitais, representado em tons de cinza (CROSTA, 1992).

O sensoriamento remoto tem sido aplicado em diversos estudos relacionados à análise de processos erosivos. As imagens de satélite e fotografias aéreas são utilizadas para delimitar as feições erosivas, analisar a evolução temporal das feições; obter produtos cartográficos básicos e interpretativos, entre outras informações.

Uma das técnicas do sensoriamento remoto, que contribuem para a avaliação de feições erosivas, constitui a avaliação temporal. Dantas-Ferreira e Pejon (2004) desenvolveram um estudo temporal na região de São Pedro (SP) utilizando fotografias aéreas com diferentes datas (1962, 1972, 1978 e 2000). A partir destes dados, aplicando-se técnica de fotointerpretação, os autores elaboraram o Mapa de Feições, que permitiu analisar as erosões cadastradas quanto ao tipo (sulcos, ravinas ou voçorocas); característica de evolução; localização; uso do solo e outros.

Utilizando diversas técnicas e métodos, que possuem uma relação com o sensoriamento remoto, Poesen et al. (2003) sugerem algumas medidas para avaliação dos processos erosivos, com base na idade das voçorocas. Para análise das feições com menos de 10 anos, deverão ser realizados sobrevoo de baixa altitude, de maneira regular. A avaliação de feições com idade de 10 a 70 anos deve ser realizada por meio do uso de fotografias aéreas e para as feições com mais de 70 anos deve ser analisados dados históricos, como fotografias aéreas e imagens antigas, que permitam a datação dos depósitos decorrentes das erosões.

\subsubsection{Processamento automático}

Considerando as diversas funções do SIG, em muitos trabalhos tem sido realizado o processamento automático de dados espaciais com a finalidade de se obter diferentes dados, como modelo digital de elevação, mapa de declividades, mapa de área de drenagem, rede de drenagem, entre outros. 
Para elaboração do limiar crítico de desencadeamento das erosões diversos autores utilizaram SIG, seja para obtenção do MDE (Modelo Digital de Elevação) ou parâmetros A e S, entre eles cita-se: Menéndez-Duarte et al. (2009), Gutiérrez et al. (2009); Nazari Samani et al. (2009); Araújo (2011) e Stabile (2013).

\subsubsection{MDE}

O Modelo Digital de Elevação (MDE) pode ser definido com um modelo matemático interpolado a partir de valores de cota do terreno em relação ao nível do mar, que representam uma superfície contínua, definida em um sistema de projeção cartográfica. Estes modelos podem ser apresentados de duas maneiras: formato vetorial Triangular Irregular Network (TIN) ou formato matricial "raster", disposto em uma matriz regular composta por linhas e colunas (AUGUSTO FILHO, 2013).

Segundo o autor citado, as principais diferenças entre os formatos vetoriais e matriciais são observadas nos fundos de vale e divisores topográficos. A representação destas regiões no formato TIN tende a ser mais grosseira diferente do formato raster, que apresenta uma interpolação mais suave, e por isso tem um aspecto visual melhor, como pode ser observado na Figura 21. Recomenda-se a aplicação de modelos com formatos TIN para realização de estudos planimétricos, como obras de terraplanagem, bem como o formato raster deve ser utilizado quando se torna fundamental a representação de uma superfície de elevação precisa e hidrologicamente consistente.

Figura 21 - Representação dos formatos vetoriais e matriciais.
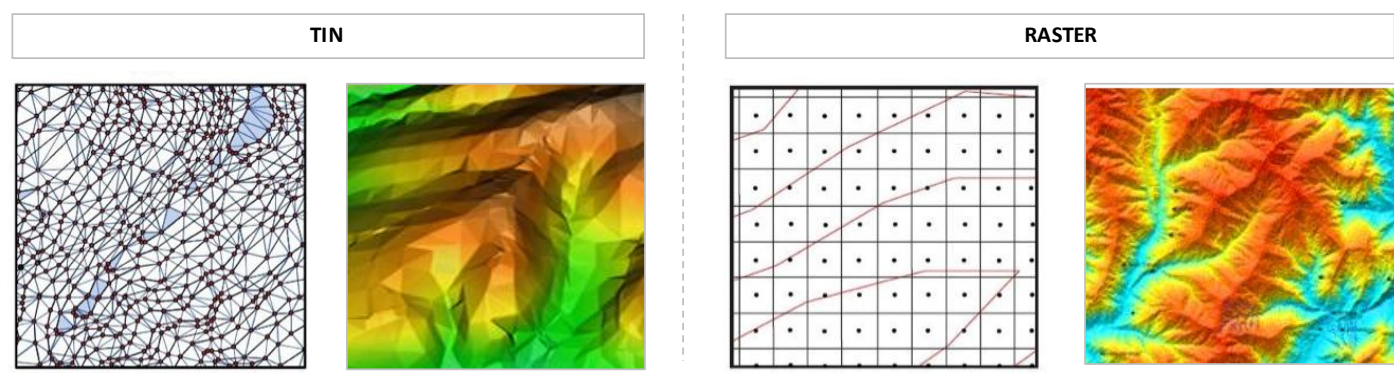

Fonte: Adaptado de Walsh, 2017.

Os MDE são elaborados através das informações altimétricas do terreno, que podem ser obtidas de diferentes formas: levantamento topográfico; sensores orbitais ou pela interpolação de dados vetoriais, como curvas de nível, pontos cotados e rede de drenagem. A 
interpolação destes dados pode ser realizada por diferentes métodos, dependendo do software a ser utilizado.

Para elaboração dos MDE no ArcGIS utiliza-se a ferramenta Topo to Raster, que realiza a interpolação dos dados com base na técnica de diferenças finitas (HUTCHINSON, 1988, 1989). O processamento é otimizado pelo método da distância inversa ponderada (IDW - Inverse Distance Weighted), que determina o valor de um pixel não previsto a partir dos valores dos pixels mais próximos, assumindo para isto que cada ponto medido tem uma influência (peso) que diminui conforme a distância dos dados matriciais (ESRI, 2017).

A ferramenta Topo to Raster apresenta como vantagem a representação de um modelo de saída hidrologicamente consistente, pois durante a interpolação da superfície de elevação leva-se em consideração a estrutura da rede de drenagem e a conexão entre os canais. A validação qualitativa dos modelos pode ser realizada gerando de maneira automática as curvas de nível, com o intuito de verificar se os valores de elevação do modelo estão em conformidade com a base cartográfica, para isto utiliza-se a ferramenta "Countor Interval" (AUGUSTO FILHO, 2011). A Figura 22, apresenta um esquema das principais etapas para elaboração do MDE no ArcGIS.

Figura 22 - Processamento para obtenção do MDE.

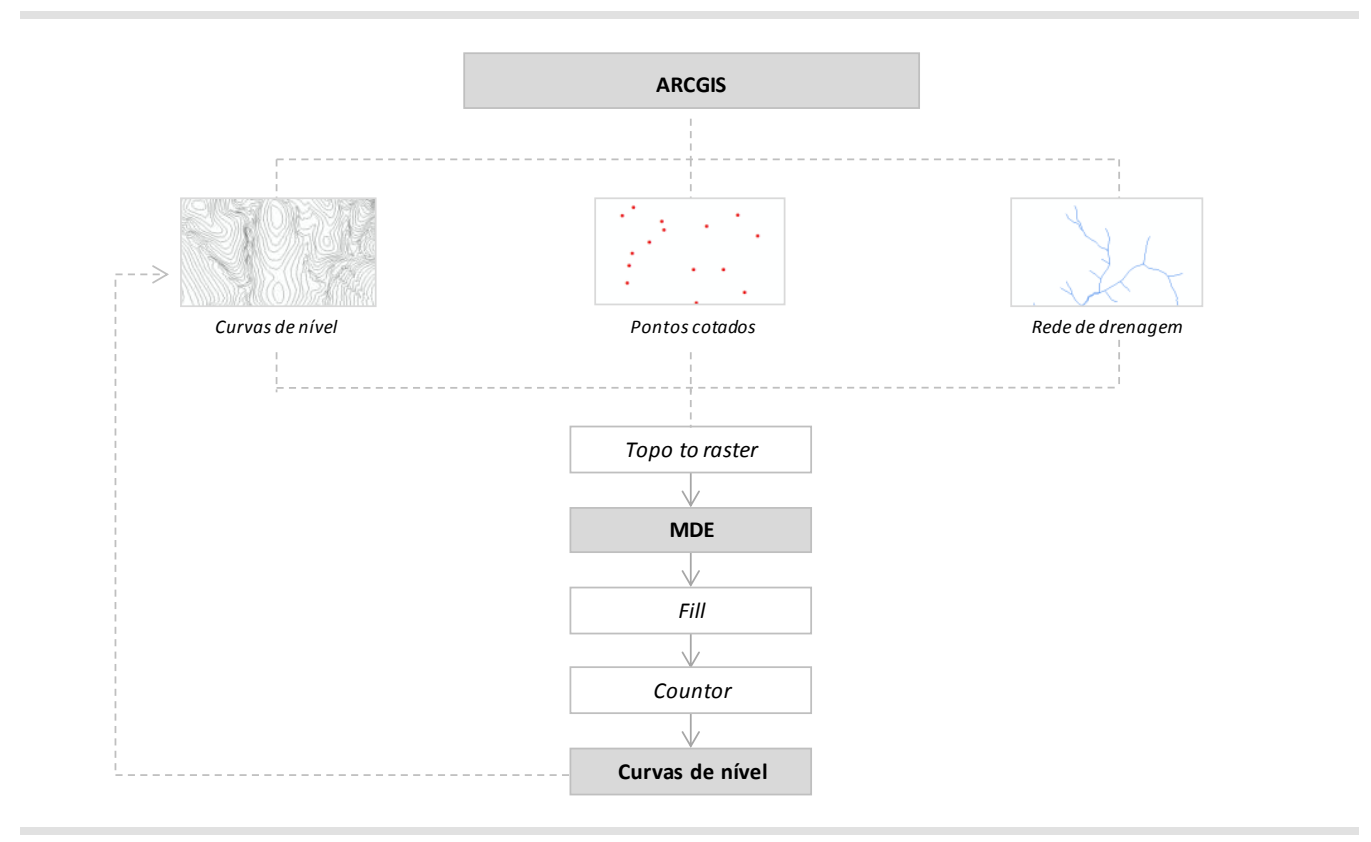

$\mathrm{O}$ arquivo gerado tende a apresentar erros na interpolação devido às resoluções dos dados de entrada, portanto conforme citado por Augusto Filho (2011), deve-se realizar a correção do modelo com a aplicação de filtros, que removem as depressões ou picos (sinks) 
decorrentes destes erros. No ArcGIS utiliza-se o Fill, que realiza todas as iterações necessárias para que todos os pixels destas depressões estejam com valores (z) dentro de um limite específico, conforme ilustrada na Figura 23.

Figura 23 - Representação da ferramenta Fill.
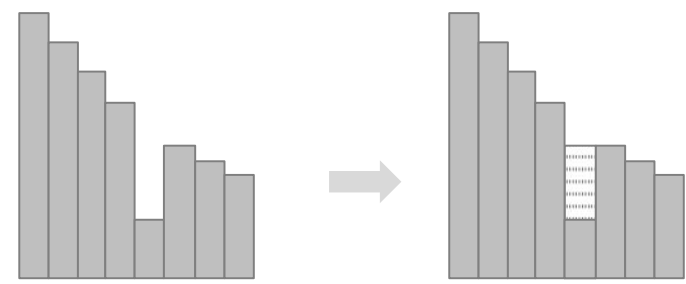

Depressões

preenchidas pelo Fill

Fonte: Adaptado de ESRI (2017).

A confiabilidade dos modelos produzidos está diretamente relacionada com os parâmetros de entrada, que devem estar em escala compatível com o tamanho do pixel de saída. Além disso, a influência da resolução espacial dos MDE reflete significativamente na avaliação dos diversos processos geomorfológicos.

Quinn et al. (1991), demonstraram que a obtenção do índice topográfico ( $a / \tan \beta)$, que relaciona índice geomorfológico $(a)$ e ângulo da declividade $(\tan \beta)$, aplicado na análise dos mecanismos de escoamento em encostas, depende da escala utilizada na elaboração do MDE, uma vez que a representação adequada de seus parâmetros, depende do tamanho de pixel adotado. Os autores destacam também a importância de uma avaliação em campo, a fim de que a representação espacial da superfície esteja em consonância com as reais características da área.

Em relação à predição dos processos decorrentes do escoamento superficial, como as erosões, Zhang e Montgomery (1994), afirmam que a representação das zonas de saturação depende do tamanho do grid a ser utilizado, pois devem estar em conformidade com as características da encosta, favorecendo a representação dos processos do geomórficos e hidrológicos. Os autores recomendam ainda, a adoção de modelos com resolução menor que 10 metros.

De acordo com Sorensen e Seibert (2007), a resolução do DEM afeta significativamente a obtenção de parâmetros como a área acumulada, pois apresentam relação direta com o tamanho do pixel, pois os valores do fluxo acumulado são calculados pixel a pixel, portanto, dependendo da escala utilizada podem ocorrer perdas de informações 
hidrológicas. Para os autores a resolução ideal depende do parâmetro a ser estimado e da sua variação topográfica, portanto, dados com menores variações não requerem modelos com resoluções maiores.

Ramos et al. (2003) também citam que os mapas de áreas de contribuição, apresentam relação direta com a precisão dos MDE. Os modelos utilizados devem representar adequadamente os diferentes valores de elevação para cada porção do terreno, e também as trajetórias do fluxo hídrico, portanto, recomenda-se a utilização de modelos hidrologicamente consistente.

\subsubsection{Aspectos hidrológicos}

A utilização do SIG na modelagem hidrológica favorece o processamento automático dos dados e auxilia a delimitação de bacias e sub-bacias hidrográficas; rede de drenagem; mapas de direção de fluxo; fluxo acumulado, entre outros, contribuindo significativamente para o desenvolvimento de diversas pesquisas.

Como a aplicação do SIG tem sido cada vez mais frequente, diversos pesquisadores desenvolveram ferramentas, "open source", que surgiram como alternativas para análise do terreno (ABERA et al., 2014). A Tabela 11 apresenta as características e tipos de análise que podem ser realizadas nestes softwares.

Tabela 11 - Softwares livres análise hidrológica.

\begin{tabular}{|c|c|c|c|c|c|c|}
\hline & TauDEM & LandSerf & GeoNET & Whitebox & GRASS GIS & uDig Spatial \\
\hline Autor & $\begin{array}{c}\text { Tarboton } \\
\text { (1997) }\end{array}$ & Wood (2009) & $\begin{array}{l}\text { Passalacqua } \\
\text { et al. (2010) }\end{array}$ & $\begin{array}{l}\text { Lindsay } \\
(2005)\end{array}$ & $\begin{array}{l}\text { Mitasova; } \\
\text { Neteler } \\
(2004)\end{array}$ & $\begin{array}{l}\text { Abera et al. } \\
\text { (2014) }\end{array}$ \\
\hline $\begin{array}{l}\text { Dados de } \\
\text { superficie }\end{array}$ & $\begin{array}{l}\text { Declividade; } \\
\text { aspecto; } \\
\text { curvatura }\end{array}$ & $\begin{array}{l}\text { Declividade; } \\
\text { aspecto; } \\
\text { curvatura }\end{array}$ & $\begin{array}{c}\text { Declividade; } \\
\text { curvatura; } \\
\text { landforms }\end{array}$ & $\begin{array}{l}\text { Declividade; } \\
\text { aspecto; } \\
\text { curvatura }\end{array}$ & $\begin{array}{l}\text { Declividade; } \\
\text { aspecto; } \\
\text { curvatura; } \\
\text { landforms }\end{array}$ & $\begin{array}{l}\text { Declividade; } \\
\text { aspecto; } \\
\text { curvatura }\end{array}$ \\
\hline $\begin{array}{l}\text { Direção de } \\
\quad \text { fluxo }\end{array}$ & $\mathrm{D} \infty ; \mathrm{D} 8$ & D8 & $\mathrm{D} \infty ; \mathrm{D} 8$ & $\begin{array}{l}\text { Dळ; D8; } \\
\text { FD8 }\end{array}$ & D8; MFD & D8 \\
\hline $\begin{array}{c}\text { Delimitação } \\
\text { de bacias }\end{array}$ & Sim & Sim & Sim & Sim & Sim & Sim \\
\hline $\begin{array}{c}\text { Índice } \\
\text { topográfico }\end{array}$ & Sim & - & - & Sim & Sim & Sim \\
\hline $\begin{array}{l}\text { Método de } \\
\text { interpolação }\end{array}$ & $\begin{array}{c}\text { IDW; TIN; } \\
\text { Splines }\end{array}$ & Cressman & - & $\begin{array}{c}\text { IDW; } \\
\text { Nearest } \\
\text { Neighbour }\end{array}$ & $\begin{array}{c}\text { IDW; Nearest } \\
\text { Neighbour }\end{array}$ & $\begin{array}{c}\text { IDW; } \\
\text { Delaunay } \\
\text { Triangulation; } \\
\text { Thin } \\
\text { Plate Spline }\end{array}$ \\
\hline $\begin{array}{l}\text { Visualização } \\
\text { (layers) }\end{array}$ & Sim & Sim & Sim & Hillshade & $\begin{array}{l}3 \mathrm{D} \text { vector; } \\
\text { voxel }\end{array}$ & Aspect; 3D \\
\hline
\end{tabular}


Como apresento na Tabela 11 o processamento automático de dados espaciais, visando à análise hidrológica, pode ser realizado por meio da aplicação de diferentes algoritmos: D8, D-Infinity, Fd8. O primeiro deles surgiu em 1984, proposto por O'Callaghan e Mark (1984) e a partir deste método outros foram propostos, como descrito na Tabela 12.

Tabela 12 - Algoritmos utilizados nas análises hidrológicas.

\begin{tabular}{c|c|c}
\hline Algoritmo & Autor & Princípio \\
\hline $\begin{array}{c}\text { D8 } \\
\text { (Deterministic Eight-Node) }\end{array}$ & O'Callaghan; Mark (1984) & $\begin{array}{c}\text { Define a direção do fluxo para oito } \\
\text { possíveis direções, conforme o } \\
\text { declive mais acentuado. }\end{array}$ \\
\hline $\begin{array}{c}\text { Rho8 } \\
\text { Random eight-node })\end{array}$ & $\begin{array}{c}\text { Fairfield; Leymarie } \\
(1991)\end{array}$ & $\begin{array}{c}\text { Fluxo distribuído em função da } \\
\text { probabilidade calculada a partir da } \\
\text { declividade. }\end{array}$ \\
\hline FD8 & Quinn et al. (1991) & $\begin{array}{c}\text { Define o fluxo em função da } \\
\text { declividade. }\end{array}$ \\
\hline MF & Freeman (1991) & $\begin{array}{c}\text { Distribui o fluxo à jusante de forma } \\
\text { proporcional a declividade. }\end{array}$ \\
\hline KINEMATIC & Lea (1992) & $\begin{array}{c}\text { Associa a direção do fluxo ao } \\
\text { aspecto de cada pixel. }\end{array}$ \\
\hline $\begin{array}{c}\text { DEMON } \\
\text { (Digital elevation model networks) }\end{array}$ & Costa-Cabral; Burges (1994) & $\begin{array}{c}\text { Determina o fluxo com base na } \\
\text { orientação da vertente. }\end{array}$ \\
\hline D-Infinity & Tarboton (1997) & $\begin{array}{c}\text { Define as direções de fluxo a partir } \\
\text { das facetas triangulares conforme a } \\
\text { direção mais íngreme. }\end{array}$ \\
\hline
\end{tabular}

Dentre estes métodos um dos mais utilizados na literatura é o D8, devido a sua simplicidade e disponibilidade em softwares, como o ArcGIS. No entanto em diversos trabalhos a modelagem hidrológica, visando à avaliação de processos geomorfológicos, tem sido realizada por meio do algoritmo D-Infinity.

\subsection{Métodos D8 e D-Infinity}

O D8 é o algoritmo para determinação mais antigo e mais simples, e vem sendo amplamente empregado na elaboração dos mapas de direção de fluxo, fluxo acumulado e delimitação automática de bacias hidrográficas. O método proposto por O’Callaghan e Mark (1984) define a direção do fluxo a partir da diferença de cota existente entre oito pixels vizinhos, para isto, considera uma célula central entre estes pixels e direciona o fluxo para o pixel com maior inclinação. A Figura 24 ilustra o processamento da direção de fluxo a parti do D8. 
Figura 24 - Direção de fluxo pelo método D8.

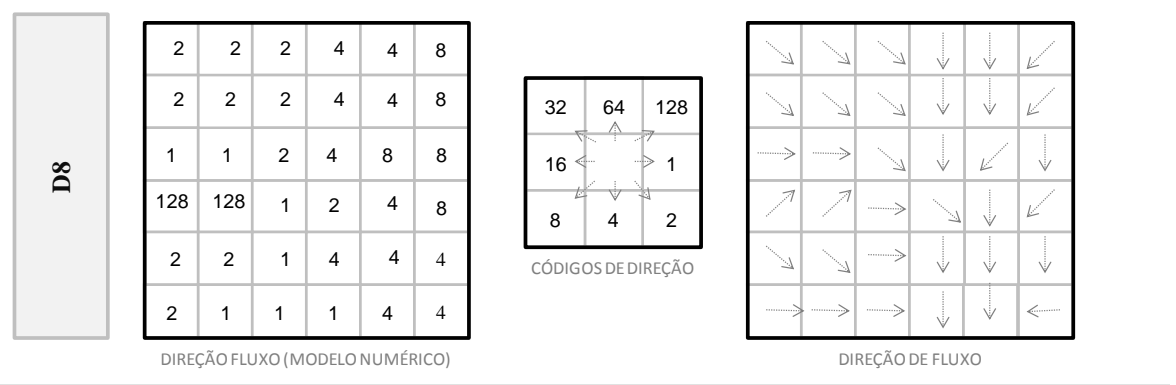

Fonte: Adaptado de ESRI (2017).

Apesar da sua simplicidade e ampla aplicação Tarboton (1997), cita que o D8 apresenta como desvantagem a discretização do fluxo, que ocorre porque o fluxo é distribuído igualmente em apenas oito direções de fluxo separadas por $45^{\circ}$, resultando em um modelo com linhas de fluxo paralelas ou convergentes, que não condizem com a realidade.

Para solucionar este problema Fairfield e Leymarie (1991) propuseram o Rh8 e Quinn et al. (1991) o FD8, com o intuito de definir a direção do fluxo baseando em análise estatística, sendo a distribuição do fluxo realizada de maneira proporcional conforme a inclinação dos pixels vizinhos. Lea (1992) e Costa-Cabral e Burges (1994) propuseram o KINEMATIC e DEMON, respectivamente, e definem as direções de fluxo com base em plano ajustado a partir das extremidades dos pixels, e não para um pixel central, como os demais métodos.

No entanto, conforme citado por Tarboton (1997), os modelos de múltipla direção baseados na declividade (Rh8, FD8, KINEMATIC) tendem a gerar caminhos de fluxo dispersos para os pixels vizinhos de menor elevação, pois a direção é determinada em função de um único pixel.

Considerando as vantagens e desvantagens de cada um destes métodos, Tarboton (1997) propôs o D-Infinity. Neste método a direção de fluxo é centrada em um pixel de interesse e direcionada para o pixel com maior elevação entre as oito facetas triangulares, que evitam a propagação de valores aproximados, e também a influência dos pixels vizinhos com menor valor de elevação. Caso as direções não sejam cardinais ou diagonais, considera-se o ângulo entre os dois pixels descendentes. A Figura 25 ilustra o cálculo destas direções a partir do D-Infinity. 
Figura 25 - Direção de fluxo pelo método D-Infinity.

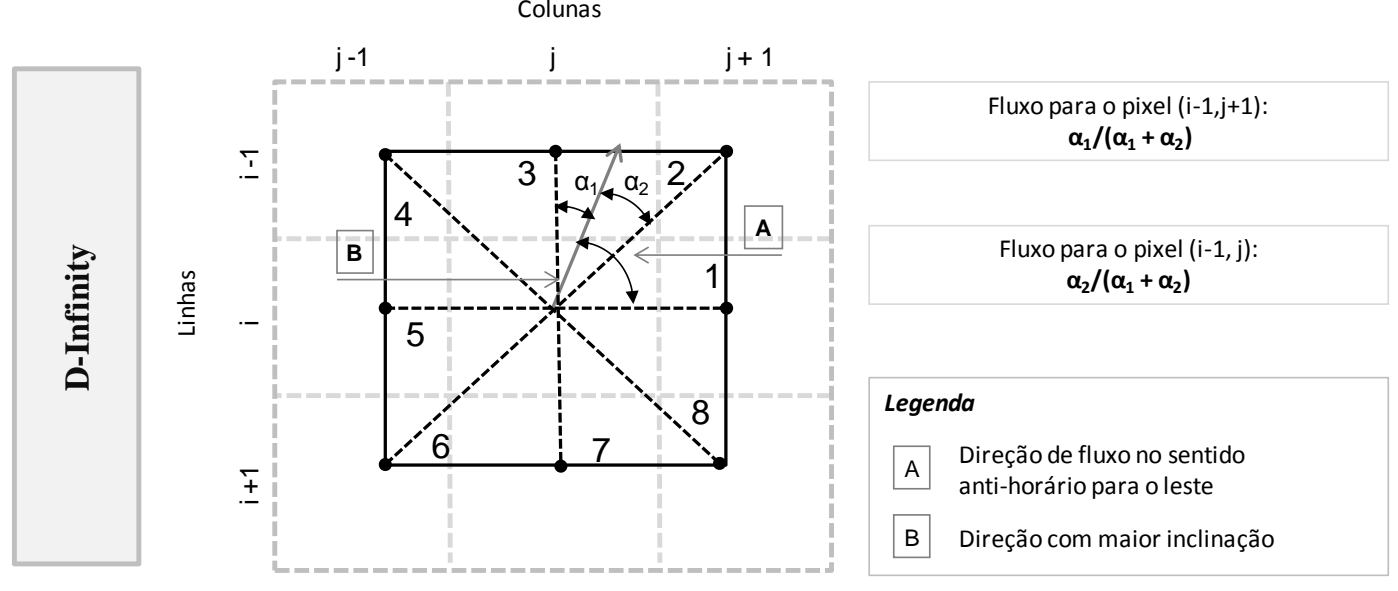

Fonte: Adaptado de Tarboton (1997).

A Figura 26 apresenta os mapas de influência para diversos algoritmos de interpolação, observa-se que o D8 restringe a direção de fluxo ao grid do modelo; no MS ocorre uma dispersão substancial; o KINEMATIC tende a gerar direções pixel a pixel, em forma de "escada"; o DEMON também apresenta dispersão e uma tendência de direções restritas ao grid, por fim, o D-Infinity apresenta menor divergência entre os contornos e pixels alinhada conforme a inclinação topográfica (TARBOTON, 1997).

Figura 26 - Mapa de influência para os diferentes métodos.
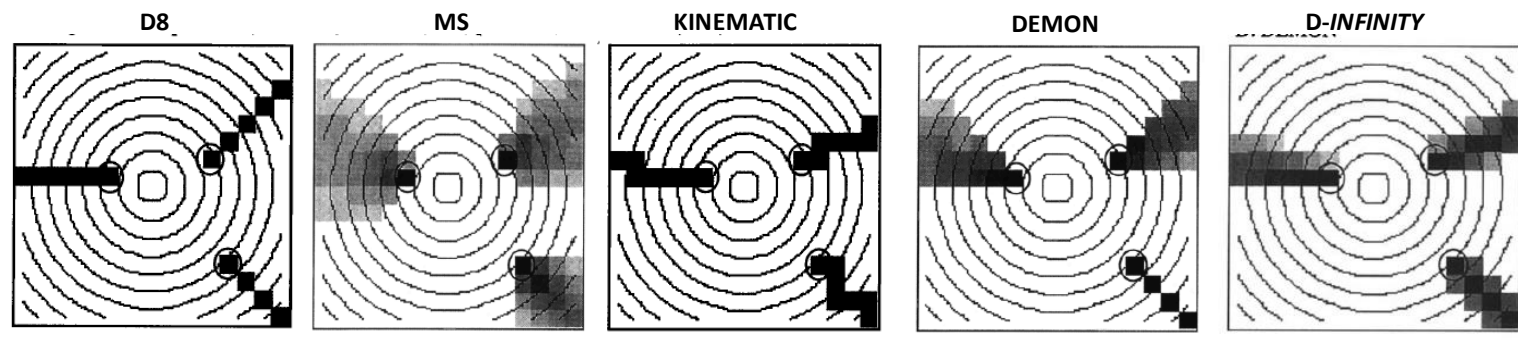

Legenda

1 a $100 \%$ influência

0 ou nenhuma influência

Fonte: Adaptado de Tarboton (1997).

Em diversos trabalhos tem sido realizada uma análise hidrológica, com o intuito de comparar as vantagens e desvantagens destes algoritmos. Farinasso et al. (2006) verificaram que, o D-Infinity permite uma melhor representação dos divisores de água e canais de drenagem, gerando consequentemente linhas de fluxo continuas, diferente do D8 que gera linhas angulares que se desviam dos canais de drenagem. 
Ao avaliar a interferência dos métodos na elaboração automática da rede de drenagem, Oliveira et al. (2013) e Ramos et al. (2013), concluíram que o D-Infinity define as regiões de distribuição de fluxo, de maneira mais homogênea, favorecendo a identificação dos caminhos preferenciais, e consequentemente uma rede de drenagem mais precisa. Ramos et al. (2013) constataram ainda que este algoritmo se mostra mais confiável, para aplicação em modelos de previsão de áreas instáveis, processos erosivos, entre outros.

\subsubsection{2 Área de Contribuição}

O mapa de área de contribuição representa as zonas potenciais de saturação no relevo, que propiciam o desencadeamento de processos geomorfológicos. Estes mapas têm sido aplicados na previsão de áreas de instabilidade na encosta; avaliação do posicionamento espacial das erosões; elaboração dos índices geomorfológicos (relação entre área de contribuição e unidade de contorno), entre outros.

As áreas de contribuição também denominadas como fluxo acumulado permitem a identificação espacial dos divisores topográficos, e confluência e divergência das linhas de fluxo, determinadas em função da curvatura da encosta, desta forma, pode ser extraída a rede de drenagem e delimitação das bacias hidrográficas (VALERIANO, 2008).

A área de contribuição é calculada como a contribuição do próprio pixel mais a contribuição dos pixels vizinhos, conforme a direção do fluxo, desta forma, é atribuído a cada pixel o valor referente à quantidade de pixels que contribuem até ele (Figura 27). Os valores são expressos em unidade de contorno, que corresponde ao tamanho do pixel do modelo de entrada (TAUDEM, 2017).

Figura 27 - Representação do fluxo acumulado.

\begin{tabular}{|c|c|c|c|c|c|}
\hline 1 & 1 & 1 & 1 & 1 \\
\hline 1 & 3 & 3 & 3 & 1 \\
\hline 1 & 1 & 11 & 1 & 2 \\
\hline 2 & 1 & 1 & 15 & 1 \\
\hline 1 & 5 & 2 & 20 & 2 \\
\hline
\end{tabular}

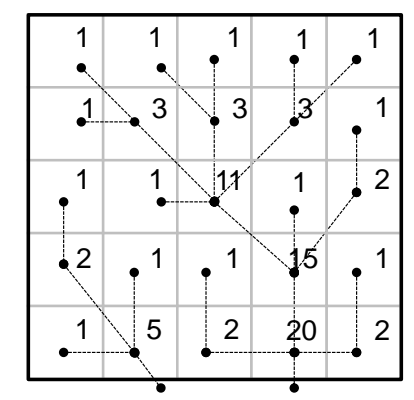

Fonte: Adaptado de Chaves (2002).

O processamento dos mapas de área de contribuição deve ser realizado em etapas e requer a elaboração de planos de informação básicos, que são utilizados como dados de 
entrada. Diversos softwares são utilizados para processamento destes dados, entre eles destaca-se o ArcGIS (ESRI ${ }^{\circledR}$ ) e TauDEM (TARBOTON, 1997).

O TauDEM (Terrain Analysis Using Digital Elevation Models) é um software (Toolbox ArcGIS) que permite a análise e extração de informações hidrológicas, a partir dos modelos digitais de elevação. Algumas de suas aplicações são: desenvolvimento de MDE hidrologicamente consistentes; elaboração de mapas de direção de fluxo; delimitação de rede de drenagem e bacias hidrográficas; e análises especificas de encostas. Além disso, também permite a elaboração dos mapas de área de contribuição a partir dos algoritmos, D8 e DInfinity (TAUDEM, 2017).

A elaboração destes mapas no TauDEM é realizada em três etapas (Figura 28), sendo a primeira delas a aplicação da ferramenta "Pit" que preenche os pixels que possuem valores menores que os seus vizinhos, gerando como dado de saída modelos digitais de elevação precisos e hidrologicamente consistentes. O processamento seguinte envolve a elaboração do mapa de direção de fluxo, que será em função do algoritmo utilizado, por fim, a última etapa é a elaboração do mapa de área de contribuição.

Figura 28 - Etapas para elaboração do mapa de área de contribuição no TauDEM.

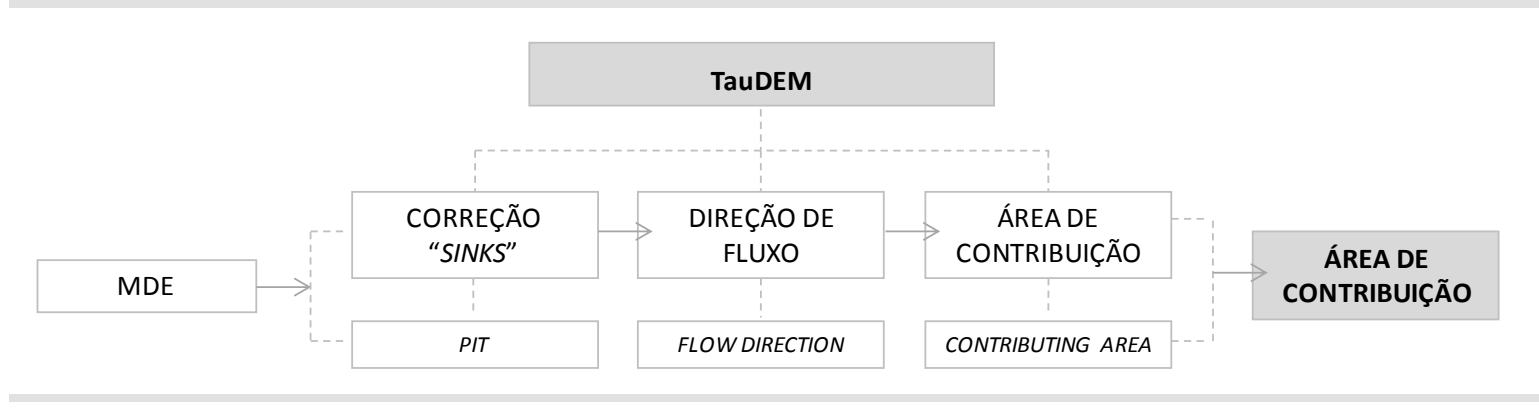

No ArcGIS o processamento dos dados para elaboração dos mapas de área de contribuição é realizado através das ferramentas disponíveis no "Spatial Analyst Tools Hydrology". Como ilustrado na Figura 29 o processamento dos dados é semelhante ao TauDEM, no entanto, utiliza-se apenas o algoritmo D8.

A primeira etapa consiste na aplicação do "Fill" para remoção dos "sinks", descrito no item (2.5.3.1). A segunda etapa é a elaboração da direção de fluxo, que resulta em um raster de saída com pixels cujos valores variam de 1 a 255 , conforme a orientação da direção. Por fim aplica-se a ferramenta "flow accumulation" que gera um raster com os valores de cada pixel que contribuem para uma célula especifica. Os pixels com valores altos representam as áreas com elevada acumulação de água e representam os canais de fluxo, enquanto aqueles 
com valor igual a zero, simulam os locais mais altos, como os divisores topográficos (ESRI, 2017).

Figura 29 - Etapas para elaboração do mapa de área de contribuição no ArcGIS.

\section{ArcGIS - Hydrology}

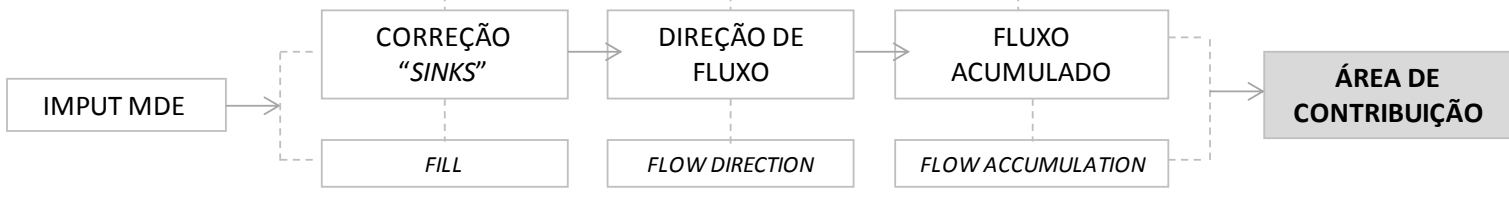

Além destes mapas é possível realizar no "Hydrology" a delimitação da rede de drenagem a partir do mapa de fluxo acumulado. Para isto, conforme citado por Chaves (2002) é definido um limiar (threshold) que determina a área mínima da bacia de contribuição, portanto, todos os pixels com valor superior a este limiar são classificados como parte da rede de drenagem. Para definir este limiar utiliza-se a ferramenta "Con" que reclassifica os pixels conforme o valor estabelecido. A Figura 30 ilustra a aplicação do limiar (threshold).

Figura 30 - Representação do limiar (threshold).

\begin{tabular}{|c|c|c|c|c|c|}
\hline \multirow{5}{*}{ 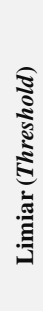 } & 0 & 0 & 0 & 0 & 0 \\
\hline & 0 & 3 & 2 & 2 & 0 \\
\hline & 0 & 0 & 11 & 0 & 1 \\
\hline & 0 & 0 & 1 & 15 & 0 \\
\hline & 0 & 2 & 5 & 24 & 1 \\
\hline
\end{tabular}

\begin{tabular}{|r|r|r|r|r|}
\hline 0 & 0 & 0 & 0 & 0 \\
\hline 0 & 3 & 2 & 2 & 0 \\
\hline 0 & 0 & 11 & 0 & 1 \\
\hline 0 & 0 & 1 & 15 & 0 \\
\hline 0 & 2 & 5 & 24 & 1 \\
\hline
\end{tabular}

Fonte: Adaptado de Chaves (2002).

Outra aplicação importante das ferramentas disponíveis no "Hydrology" em análise hidrológica é a delimitação de bacias e sub-bacias hidrográficas a partir do MDE hidrologicamente consistente e a direção de fluxo. Turcotte et al. (2001) citam que para obter este tipo de representação os parâmetros de entrada (MDE) devem apresentar uma estrutura que permita a definição da drenagem interna da bacia a ser analisada.

Os autores apresentam uma rotina para delimitação das bacias hidrográficas a partir do algoritmo D8 (Figura 31). No primeiro passo é calculada a direção de fluxo conforme o pixel com declive mais íngreme a jusante. Na segunda etapa, o limite da bacia hidrográfica é definido considerando todos os pixels que fluem para um ponto de saída (exutório). A rede de 
drenagem, na terceira etapa é elaborada conforme o limiar (thershold), e consequentemente as sub-bacias também são definidas considerando os pixels com área de drenagem superior ao limiar definido.

Figura 31 - Etapas para obtenção dos aspectos hidrológicos.

MODELO DIGITAL DE ELEVAÇÃO

\begin{tabular}{|l|l|l|l|l|l|}
\hline 22 & 21 & 21 & 18 & 18 & 18 \\
\hline 21 & 20 & 20 & 20 & 20 & 20 \\
\hline 20 & 16 & 18 & 19 & 20 & 20 \\
\hline 18 & 13 & 14 & 15 & 18 & 20 \\
\hline 15 & 11 & 18 & 20 & 20 & 20 \\
\hline 10 & 15 & 18 & 20 & 20 & 21 \\
\hline
\end{tabular}

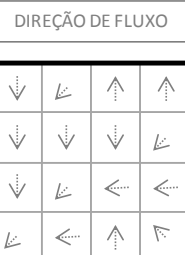

LIMITE DA BACIA
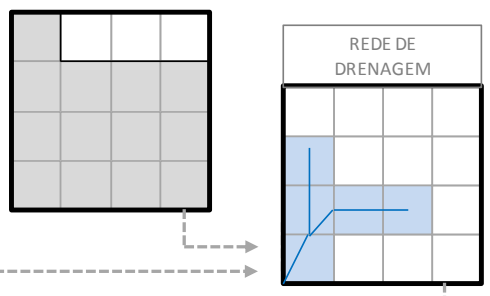

LIMITESUB-BACIAS
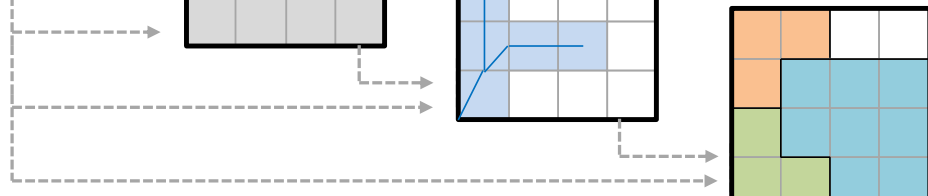

Fonte: Adaptado de Turcotte et al. (2001).

Bosquilia (2014) conclui que quantitativamente o processamento automático da rede de drenagem difere dos arquivos vetorizados, no entanto, são de grande utilidade para mapeamento de bacias onde não se dispõe destes dados. Desta forma, recomenda-se a utilização de um MDE hidrologicamente consistente, e algoritmos de interpolação propícios para obtenção de dados mais coerentes. 



\section{Caracterização Geral da Área de Estudo}

A Bacia Hidrográfica do Córrego do Meio está localizada no município de São Pedro, situado no interior do estado de São Paulo, entre as coordenadas UTM 194000/199000mE e 7507000/7491000mN, na zona 23 Sul (Figura 32). A Bacia do Córrego do Meio possui uma área de 48,06 km², na qual $5 \mathrm{~km}^{2}$ correspondem a uma porção da área urbana, e ordem de ramificação 5, segundo a classificação de Strahler. O Ribeirão do Meio que drena a região em estudo, nasce na Serra de São Pedro, e percorre toda a área com uma extensão de $41 \mathrm{~km}$, até sua foz no Rio Piracicaba.

Na Figura 32 destaca-se a Sub-Bacia dos Córregos Alpes e Retiro que possui área de $6,81 \mathrm{~km}^{2}$, e são de $3^{\mathrm{a}}$ ordem de ramificação. Parte dos resultados obtidos neste trabalho foi realizado apenas nesta região com o intuito de analisar algumas condições, para posteriormente aplicar na Bacia do Córrego do Meio.

Figura 32 - Mapa de localização da Bacia Hidrográfica do Córrego do Meio.
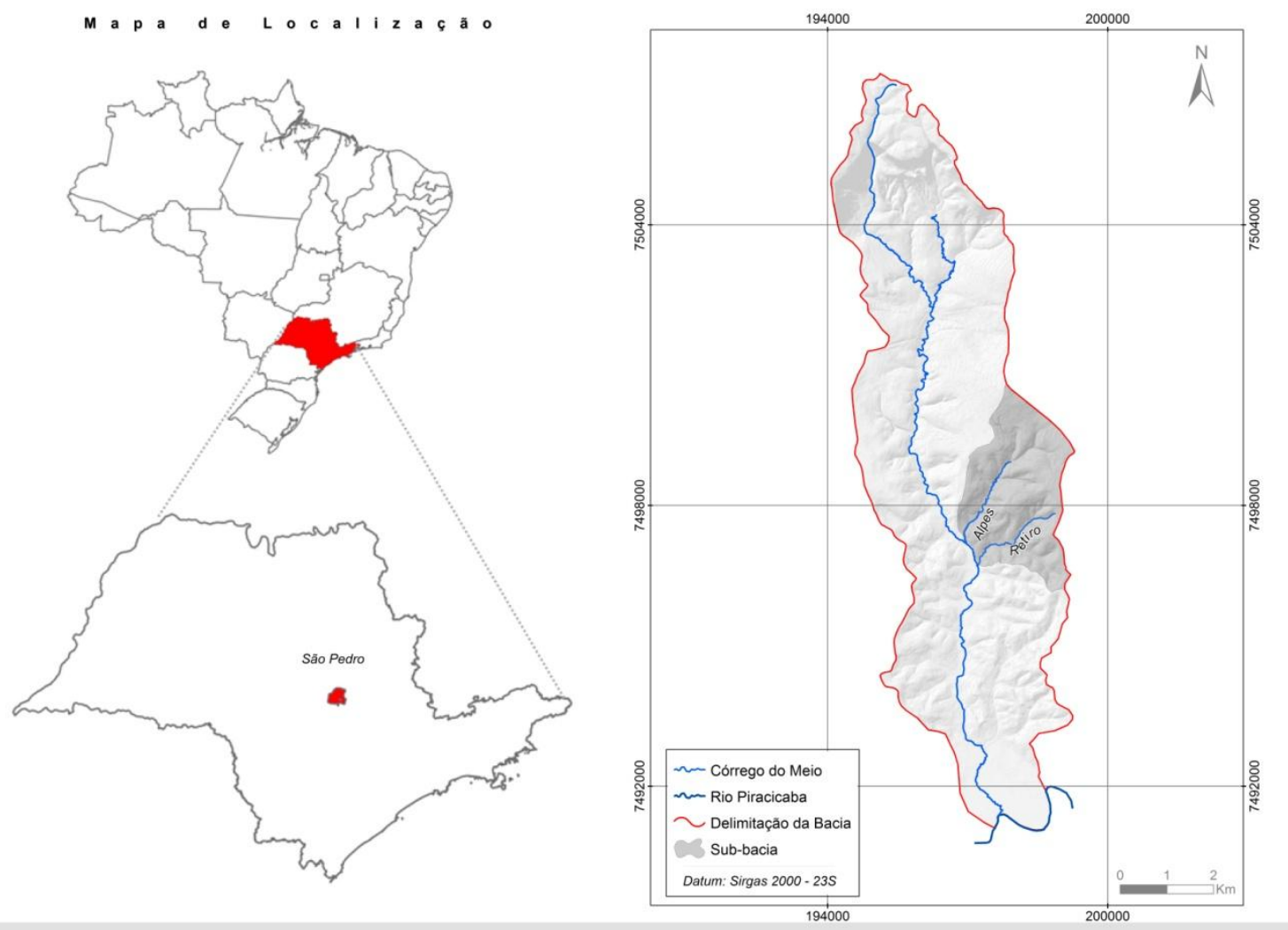

O município de São Pedro possui uma área territorial de $610 \mathrm{~km}^{2}$; população de 32.000 habitantes; PIB per capita de 14.943,55 reais; e IDHM (2010) 0,755. O turismo é a 
principal atividade econômica da região, com destaque para os atrativos naturais, culturais e históricos. Em relação à pecuária, destaca-se a criação de galinhas e bovinos, e quanto à produção agrícola, predomina o cultivo de cana-de-açúcar (IBGE, 2016).

A cidade localiza-se aproximadamente a 190 km de São Paulo, 100 km de Campinas, e 30 de Piracicaba, e tem como principais rodovias de acesso a SP 330 - Rodovia Anhanguera, e SP 280 - Rodovia Castelo Branco. Os municípios limítrofes são ao norte Itirapina e Torrinha; ao leste Charqueada; a oeste Santa Maria da Serra; e ao sul, Piracicaba (PMSP, 2016; IBGE, 2016).

\subsection{Clima}

De acordo com a classificação climática de Köppen, o município de São Pedro pertence à classe Aw, que corresponde a um clima tropical chuvoso com inverno seco, nos meses mais frios a temperatura média superior é em torno de $18^{\circ} \mathrm{C}$ e, nos meses mais secos a precipitação inferior é de $60 \mathrm{~mm}$ (CEPRAGRI, 2016). A Figura 33 apresenta a média dos dados pluviométricos mensais, para o período de 1942 a 2000.

Figura 33 - Distribuição das chuvas na região de São Pedro.

Chuvas

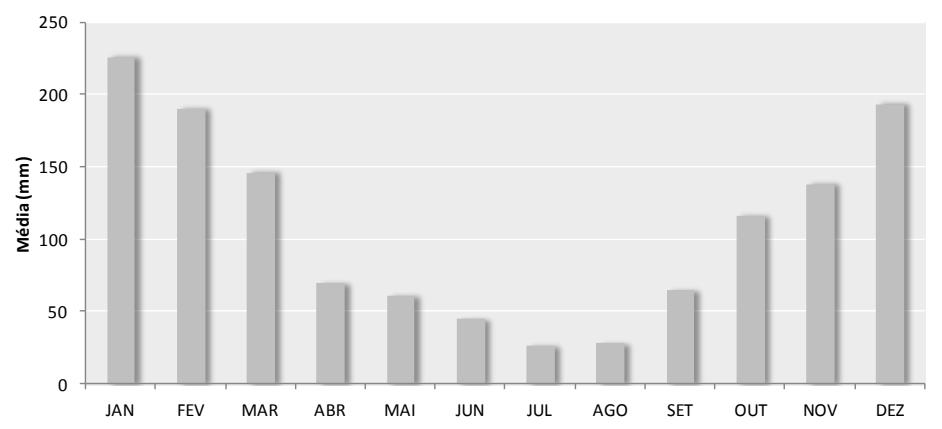

Fonte: DAEE, 2016.

\subsection{Vegetação}

Segundo o IBGE (2004), o bioma predominante no município de São Pedro é o Cerrado, que se caracteriza por uma formação vegetal do tipo savana tropical. Os tipos de cobertura florestal predominante na região, conforme o Mapa Florestal de São Pedro 1:200.000 (IF, 2001), são as áreas de mata, capoeira e reflorestamento.

As espécies vegetais que ocorrem na região próxima ao município de São Pedro são herbáceas, como Gramíneas Eragrostis perennis Doell, que se desenvolvem em ambientes abertos com elevada luminosidade. Ocorrem também plantas que podem ser consideradas 
daninhas, como Compositae; Gramineae; Leguminosae; Malvaceae; Scrophylariaceae; Sterculiaceae, que estabelecem em solos arenosos, com baixo índice de fertilidade (FACINCANI; CAVALHEIRO, 1995).

\subsection{Geologia e Geomorfologia}

A geomorfologia da área em estudo compreende três unidades geomorfológicas: Serra de São Pedro; Cuestas Basálticas (Escarpa de Serra) e Depressão Periférica (IPT, 1981). Na região ocorrem rochas sedimentares das Formações Itaqueri, Pirambóia e Botucatu, e rochas ígneas da Formação Serra Geral (PEJON, 1992). A Tabela 13 apresenta as características das unidades litoestratigráficas presentes na área.

Tabela 13 - Características litoestratigráficas das formações presentes na área em estudo.

\begin{tabular}{|c|c|c|c|}
\hline \multicolumn{3}{|c|}{ Unidades } & Características \\
\hline $\begin{array}{l}\text { Grupo } \\
\text { Bauru }\end{array}$ & $K t i$ & $\begin{array}{l}\text { Formação } \\
\text { Itaqueri }\end{array}$ & $\begin{array}{l}\text { Arenitos imaturos, geralmente grosseiros, conglomeráticos, com seixos de arenitos e } \\
\text { quartzitos. Apresentam cores variadas e espessura na ordem de dezenas de metros. }\end{array}$ \\
\hline \multirow{3}{*}{$\begin{array}{c}\text { Grupo } \\
\text { São } \\
\text { Bento }\end{array}$} & $J K s g$ & $\begin{array}{l}\text { Formação } \\
\text { Serra Geral }\end{array}$ & Basaltos, textura afanítica, com fraturamento do tipo colunar. \\
\hline & $J k b$ & $\begin{array}{l}\text { Formação } \\
\text { Botucatu }\end{array}$ & $\begin{array}{l}\text { Arenitos de granulação fina a média, silicificados, de cores amarelados, com } \\
\text { estratificação cruzadas, e fraturamentos verticais e horizontais. }\end{array}$ \\
\hline & $\operatorname{TrJp}$ & $\begin{array}{l}\text { Formação } \\
\text { Pirambóia }\end{array}$ & $\begin{array}{l}\text { Depósitos fluviais e de planície de inundação, incluindo arenitos finos a médios, siltico } \\
\text { argiloso, de estratificação cruzada ou plano-paralela; níveis de folhelhos e arenitos } \\
\text { argilosos de cores variadas e intercalações areno-conglomerática. }\end{array}$ \\
\hline
\end{tabular}

Fonte: Adaptado de Gomes (2002).

\subsubsection{Materiais inconsolidados}

Pejon (1992) elaborou o Mapa de Materiais Inconsolidados - 1:100.000 - Folha Piracicaba, que abrange a região do município de São Pedro, na qual foram identificados os materiais descritos na Tabela 14, bem como suas propriedades.

Tabela 14 - Dados referentes às principais unidades de materiais inconsolidados da região em estudo.

\begin{tabular}{|c|c|c|c|c|c|c|c|c|c|c|c|c|c|c|c|c|}
\hline \multicolumn{17}{|c|}{ Materiais Inconsolidados } \\
\hline \multirow{3}{*}{ 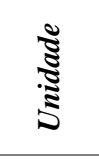 } & \multicolumn{9}{|c|}{ Granulometria } & \multicolumn{3}{|c|}{ Índices Físicos } & \multicolumn{4}{|c|}{ Ensaio de Azul de Metileno } \\
\hline & \multicolumn{3}{|c|}{ Argila } & \multicolumn{3}{|c|}{ Silte } & \multicolumn{3}{|c|}{ Areia } & \multirow{2}{*}{$\begin{array}{c}\rho_{s} \\
\mathrm{~g} / \mathrm{cm}^{3}\end{array}$} & \multirow{2}{*}{$\begin{array}{c}\rho_{d} \\
\mathrm{~g} / \mathrm{cm}^{3}\end{array}$} & \multirow{2}{*}{$e_{0}$} & \multirow{2}{*}{$\begin{array}{c}\boldsymbol{V B} \\
\mathrm{g} / 100 \mathrm{~g} \\
\text { solo }\end{array}$} & \multirow{2}{*}{$\begin{array}{c}\text { Acb } \\
\text { g/100 g } \\
\text { argila }\end{array}$} & \multirow{2}{*}{$\begin{array}{c}\boldsymbol{C T C} \\
\text { meq./100 } \\
\text { g solo }\end{array}$} & \multirow{2}{*}{$\begin{array}{c}\boldsymbol{S E} \\
\mathrm{m}^{2} / \mathrm{g} \\
\text { argila }\end{array}$} \\
\hline & Min & Méd & Max & Min & Méd & $\operatorname{Max}$ & Min & Méd & Max & & & & & & & \\
\hline $2-2-10$ & 17 & 29 & 35 & 1 & 6 & 12 & 53 & 68 & 76 & 2,68 & 1,38 & 0,97 & 0,32 & 1,1 & 1,0 & 27 \\
\hline $1-3-9$ & 10 & 38 & 56 & 8 & 17 & 35 & 24 & 44 & 64 & 2,90 & 1,34 & 1,20 & 2,26 & 4,5 & 7,1 & 109 \\
\hline $2-1-7$ & 0 & 0 & 15 & 0 & 2 & 7 & 77 & 80 & 94 & 2,65 & 1,55 & 0,70 & 0,29 & 2,8 & 0,9 & 67 \\
\hline $1-2-7$ & 10 & 10 & 15 & 10 & 10 & 15 & 75 & 80 & 89 & 2,7 & 1,5 & 0,70 & 1,86 & 11,9 & 5,8 & 283 \\
\hline \multirow{4}{*}{ 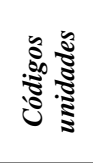 } & \multicolumn{2}{|c|}{$2-2-10$} & \multicolumn{14}{|c|}{ Transportado da Formação Itaqueri } \\
\hline & \multicolumn{2}{|c|}{$1-3-9$} & \multicolumn{14}{|c|}{ Residual da Formação Serra Geral } \\
\hline & \multicolumn{2}{|c|}{$2-1-7$} & \multicolumn{14}{|c|}{ Transportado da Formação Pirambóia (<20\% Finos) } \\
\hline & $1-$ & $2-7$ & $\mathrm{Re}$ & al de & rome & $\mathrm{P}$ & bora & & & & & & & & & \\
\hline
\end{tabular}

$\rho_{\mathrm{s}}$ - massa especifica dos sólidos; $\rho_{\mathrm{d}}$ - massa específica aparente seca; $\mathrm{e}_{0}$ - índice de vazios; VB - volume de azul de metileno adsorvido; Acb - índice de atividade da fração fina; CTC - capacidade de troca catiônica; SE - superfície específica;

Fonte: Adaptado de Pejon (1992). 
Gomes (2002) elaborou o Mapa de Materiais Inconsolidados da Bacia do Córrego do Meio - 1:20.000, e identificou os seguintes materiais: residual da Formação Itaqueri; residual da Formação Serra Geral; residual da Formação Botucatu; Sedimentos Coluvionares; Transportado da Formação Pirambóia; Sedimentos aluvionares; e residual da Formação Pirambóia.

\subsection{Pedologia}

Os solos presentes na região de São Pedro de acordo com Oliveira e Prado (1989) são latossolo roxo distrófico; latossolo vermelho escuro; latossolo vermelho amarelo; podzólico vermelho escuro; podzólico vermelho amarelo; areia quartzosa; solos litólicos e gleizados.

\subsection{Aspectos Hidrológicos}

\subsubsection{Hidrogeologia}

Considerando as informações coletadas no Mapa de Águas Subterrâneas do Estado de São Paulo - Escala 1:1.000.000 (DAEE, 2007), a unidade aquífera predominante na Bacia do Córrego do Meio é o Aquífero Guarani, que está situado em rochas do tipo arenito, e se caracteriza como um aquífero sedimentar, contínuo, parcialmente livre e dominantemente confinado, com elevada transmissividade. Esse aquífero apresenta um potencial de produção de 80 a $120 \mathrm{~m} 3 / \mathrm{h}$, considerando uma escala regional. Ocorre também na área, em sua porção ao norte, o Aquífero Serra Geral que se caracteriza por ser do tipo fraturado, descontínuo, com porosidade e permeabilidade associadas às fraturas e vesículas, sua rocha principal é o basalto, e, além disso, sua produtividade é em torno de 3 a $23 \mathrm{~m} / \mathrm{h}$.

\subsubsection{Hidrologia}

A Bacia Hidrográfica do Córrego do Meio está inserida na Unidade de Gerenciamento de Recursos Hídricos - Piracicaba/Capivari/Jundiaí (UGRHI 05) pertencente à Região Hidrográfica da Bacia do Rio Tietê. A UGRHI 05 localiza-se em uma importante região econômica e urbana do país, com sua maior parte do estado de São Paulo. Possui uma área de $15.303 \mathrm{~km}^{2}$, e uma população total de 5.000.000 habitantes, sendo Campinas, Piracicaba e Jundiaí os municípios mais populosos. Compõem esta unidade sete sub-bacias principais: rio Piracicaba e seus afluentes, rios Corumbataí, Jaguari, Camanducaia e Atibaia (CBPE, 2011). 
Especificamente em relação ao Ribeirão do Meio que drena toda a bacia hidrográfica em estudo, nasce da Serra de São Pedro, possui $41 \mathrm{~km}$, ordem de ramificação 5 conforme a classificação de Strahler, e a sua foz no Rio Piracicaba. A bacia em estudo está situada entre as Bacias do Ribeirão Vermelho, a oeste e, Samambaia a leste. Além destas, encontram-se inseridas no município de São Pedro as Bacias do Ribeirão Serelepe, Bonito, Tabaranas e Barra. Segundo a PMSP (2013), estes corpos hídricos foram enquadrados na Classe 2, conforme a legislação ambiental vigente - CONAMA 357/2005.

\subsection{Uso e Ocupação do Solo}

A partir do Mapa de Uso e Cobertura do Solo da UGRHI 5 (PCJ) - 1:25.000 (IG, 2013) verifica-se que as classes predominantes na Bacia do Meio são: pastagem; mata; cultura semiperene; e área edificada. A Tabela 15 apresenta as classes do uso e ocupação e seus respectivos percentuais, e a Figura 34 o Mapa de Uso e Cobertura da Terra (2013).

Tabela 15 - Área e percentual das classes do uso e cobertura do solo.

\begin{tabular}{|c|c|c|}
\hline Classe & Área $\left(\mathbf{k m}^{2}\right)$ & Percentual (\%) \\
\hline Área edificada & 6,19 & 12,88 \\
\hline Área úmida & 0,88 & 1,83 \\
\hline Campo natural & 3,95 & 8,22 \\
\hline Cultura semiperene & 9,03 & 18,79 \\
\hline Cultura temporária & 0,06 & 0,12 \\
\hline Curso d'água & 0,004 & 0,01 \\
\hline Grande equipamento & 0,14 & 0,29 \\
\hline Lagos, lagoas e represas & 0,10 & 0,21 \\
\hline Loteamento & 0,03 & 0,06 \\
\hline Mata & 11,00 & 22,89 \\
\hline Pastagem & 11,42 & 23,76 \\
\hline Reflorestamento & 3,04 & 6,32 \\
\hline Solo exposto & 2,22 & 4,62 \\
\hline
\end{tabular}


Figura 34 - Mapa de uso e ocupação da terra (2013) da Bacia do Córrego do Meio.

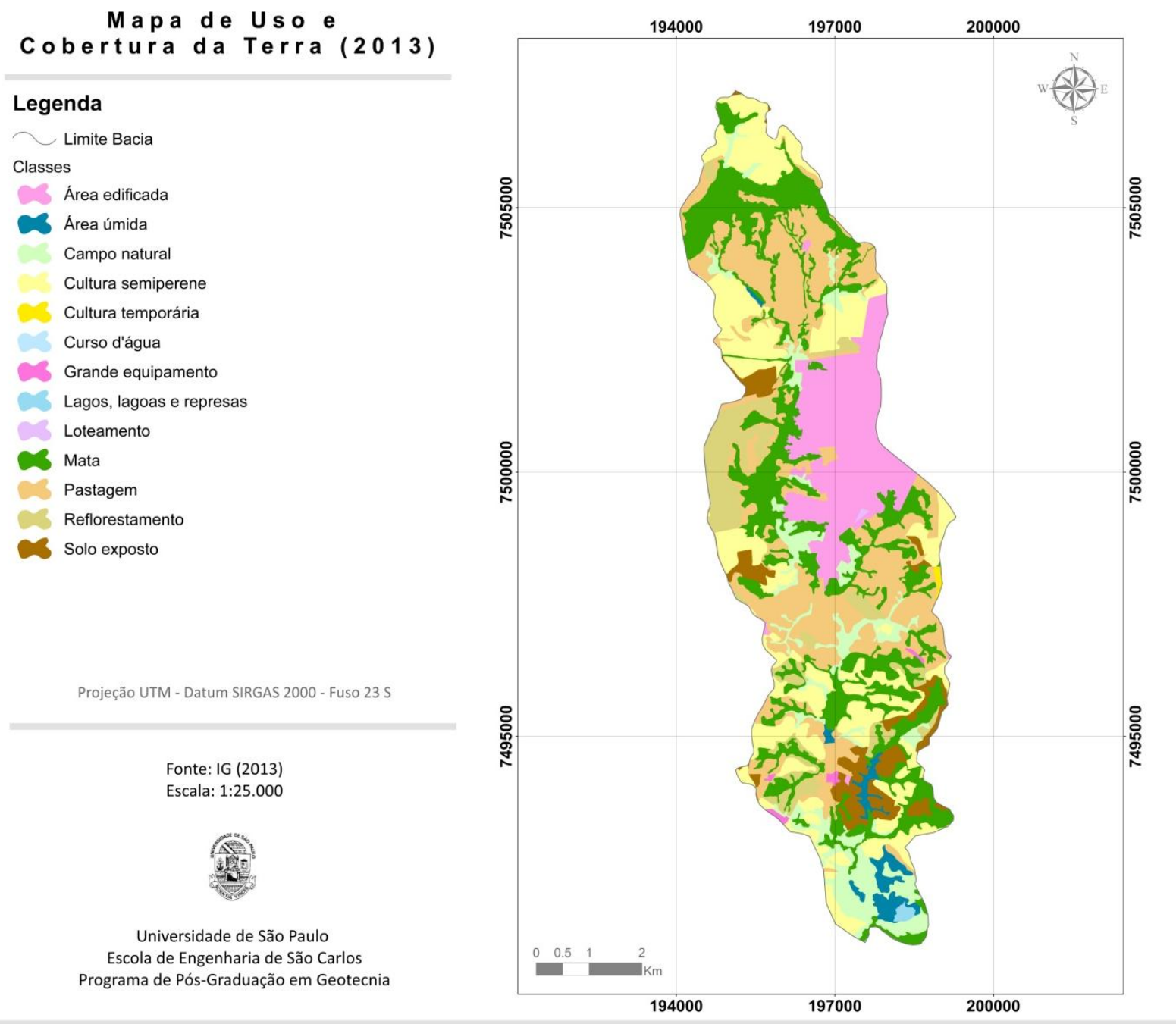

Fonte: Adaptado de IG (2013).

A área edificada corresponde às áreas residenciais, comerciais, de serviços e rodovias; espaço verde urbano são as praças, parques e demais áreas verdes públicas; cultura perene são as áreas com plantações de cana de açúcar; a área descrita como grande equipamento correspondem às áreas ocupadas por indústrias, ETE, ETA, aterro sanitário, cemitério, galpão industrial e edificações agrícolas (IG, 2013). 


\section{Materiais e Métodos}

\subsection{Materiais}

Os materiais e softwares utilizados para desenvolvimento da pesquisa estão descritos na Tabela 16. As folhas topográficas foram utilizadas para digitalização das curvas de nível, pontos cotados e rede de drenagem; as imagens de satélite para levantamento das feições erosivas atuais; os mapas e cartas para caracterização da área em estudo; e os softwares foram utilizados para estruturação do banco de dados; manipulação e elaboração dos mapas e cartas.

Tabela 16 - Materiais e softwares utilizados na pesquisa.

\begin{tabular}{|c|c|c|}
\hline Tipo & Nome/descrição & Autor/Fonte \\
\hline \multirow{7}{*}{$\begin{array}{c}\text { Folhas topográficas } \\
(1: 10.000)\end{array}$} & Fazenda São Bento (SF-23-Y-A-IV-1-NO-A) & \multirow{7}{*}{ IGC (1979) } \\
\hline & São Pedro I (SF-23-Y-A-IV-1-NO-B) & \\
\hline & São Pedro II (SF-23-Y-A-IV-1-NO-C) & \\
\hline & São Pedro III (SF-23-Y-A-IV-1-NO-D) & \\
\hline & Ribeirão do Meio (SF-23-Y-A-IV-1-NO-E) & \\
\hline & Águas de São Pedro (SF-23-Y-A-IV-1-NO-F) & \\
\hline & Ribeirão Vermelho (SF-23-Y-A-IV-1-SO-A) & \\
\hline \multirow{2}{*}{ Imagens de satélite } & Pléiades; SPOT-6; SPOT-7 (2016) & Google Earth Pro \\
\hline & Ortofotos (2011) & Emplasa \\
\hline \multirow{5}{*}{ Mapas e cartas } & Mapa de uso e ocupação do solo (1:50.000) & Dantas-Ferreira (2008) \\
\hline & Mapa de landforms (1:20.000) & \multirow{4}{*}{ Gomes (2002) } \\
\hline & Mapa de substrato rochoso $(1: 20.000)$ & \\
\hline & Mata de materiais inconsolidados (1:20.000) & \\
\hline & Carta de susceptibilidade à erosão (1:20.000) & \\
\hline \multirow{3}{*}{ Softwares } & \multicolumn{2}{|l|}{ ArcGIS 10.3} \\
\hline & \multicolumn{2}{|l|}{ AutoCAD Map } \\
\hline & \multicolumn{2}{|l|}{ TauDEM 5.1.2 } \\
\hline
\end{tabular}

\subsection{Métodos}

A sistemática de trabalho adotada na pesquisa envolveu a realização das seguintes etapas: compilação de dados da área em estudo; sensoriamento remoto; processamento dos dados em ambiente SIG; análise comparativa dos índices SxA das Sub-bacias dos Córregos dos Alpes e Retiro; elaboração dos índices SxA para a Bacia do Córrego do Meio; zoneamento de áreas críticas para ocorrência de processos erosivos (Figura 35). 
Figura 35 - Etapas de trabalho.

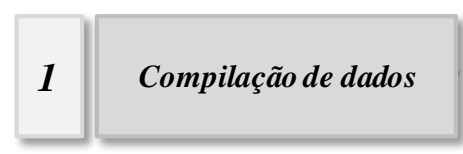

2 Sensoriamento remoto

\section{$4 \quad \begin{gathered}\text { Índice SxA } \\ \text { Bacia dos Alpes e Retiro }\end{gathered}$ \\ Indice SxA
Bacia dos Alpes e Retiro}

\section{$5 \quad$ Índice SxA Bacia do Meio}

Delimitação de novas feições

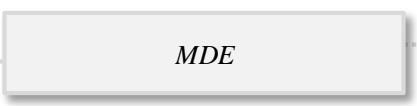

Carta de declividades

Área de contribuição

Análise comparativa

Refinamento

Índice geral

Análise detalhada

\section{Geral}

Erosões em encosta ocorrência

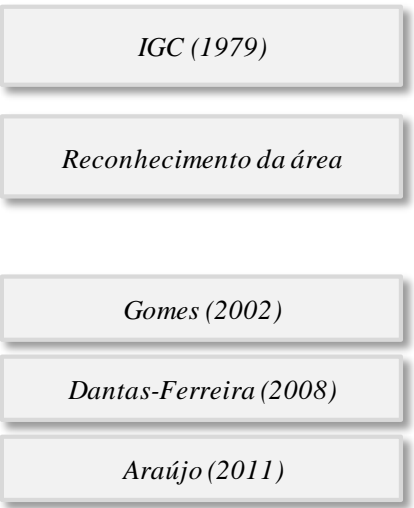

Imagem de satélite - 2016

Ortofotos - 2011

$2 \times 2 ; 10 \times 10 ; 30 \times 30$

$2 \times 2 ; 10 \times 10 ; 30 \times 30$

D8 (Hydrology)

D-Infinity (TauDEM)

D8 (Araújo, 2011)

D-Infinity

Localização

Profundidade

Comparação com a Carta de Susceptibilidade 


\subsubsection{Compilação de dados}

Esta etapa compreendeu o levantamento de informações existentes da área em estudo: dados bibliográficos; mapas topográficos; imagens de satélite; e mapas e dados geológicogeotécnicos, obtidos de trabalhos desenvolvidos na região. Também foi realizado nesta fase etapa de campo, para reconhecimento da área e avaliação in loco das principais feições.

Os dados compilados foram tabulados e organizados em um banco de dados georreferenciado, descrito na Tabela 17.

Tabela 17 - Estrutura do banco de dados da Bacia do Córrego do Meio.

\begin{tabular}{c|c|c}
\hline Dados & Escala & Fonte \\
\hline Mapas topográficos & $1: 10.000$ & IGC (1979) \\
\hline Mapa de landforms & $1: 20.000$ & Gomes (2002) \\
\hline Mapa de materiais inconsolidados & $1: 20.000$ & Gomes (2002) \\
\hline Mapa de substrato rochoso & $1: 20.000$ & Gomes (2002) \\
\hline Carta de susceptibilidade à erosão & $1: 20.000$ & Gomes (2002) \\
\hline Mapa de uso e ocupação do solo & $1: 50.000$ & Dantas-Ferreira (2008) \\
\hline Mapa de feições erosivas & $1: 15.000$ & Araújo (2011) \\
\hline Dados de ensaios geotécnicos & - & Gomes (2002) \\
\hline
\end{tabular}

A Figura 36 apresenta o mosaico com as cartas topográficas do IGC (1979), que serviu como base de referência do trabalho. A rede de drenagem, curvas de nível e pontos cotados foram digitalizadas em formato vetorial $(. d w g)$ e importadas para a extensão shapefile (.shp), que permite o processamento e edição dos arquivos no $\operatorname{ArcGIS}^{\circledR} 10.3$.

As cartas e mapas geotécnicos obtidos do trabalho de Gomes (2002) foram digitalizados no ArcGIS ${ }^{\circledR}$ 10.3, e adaptados para a Bacia do Córrego do Meio, convertendo o sistema de projeção, para "SIRGAS 2000 - Zona UTM 23S". Quanto aos ensaios laboratoriais para obtenção dos dados geotécnicos, a autora utilizou as seguintes normas:

- Granulometria conjunta: ABNT - NBR 781/1984;

- Massa específica dos sólidos $\left(\rho_{\mathrm{s}}\right)$ : ABNT - NBR 6508/1984;

- Massa específica aparente seca $\left(\rho_{\mathrm{d}}\right)$ : Zuquette (1987);

- Adsorção do Azul de metileno: Pejon (1992);

- Erodibilidade: Nogami e Villibor (1979). 
Figura 36 - Mosaico das cartas topográficas da área em estudo.

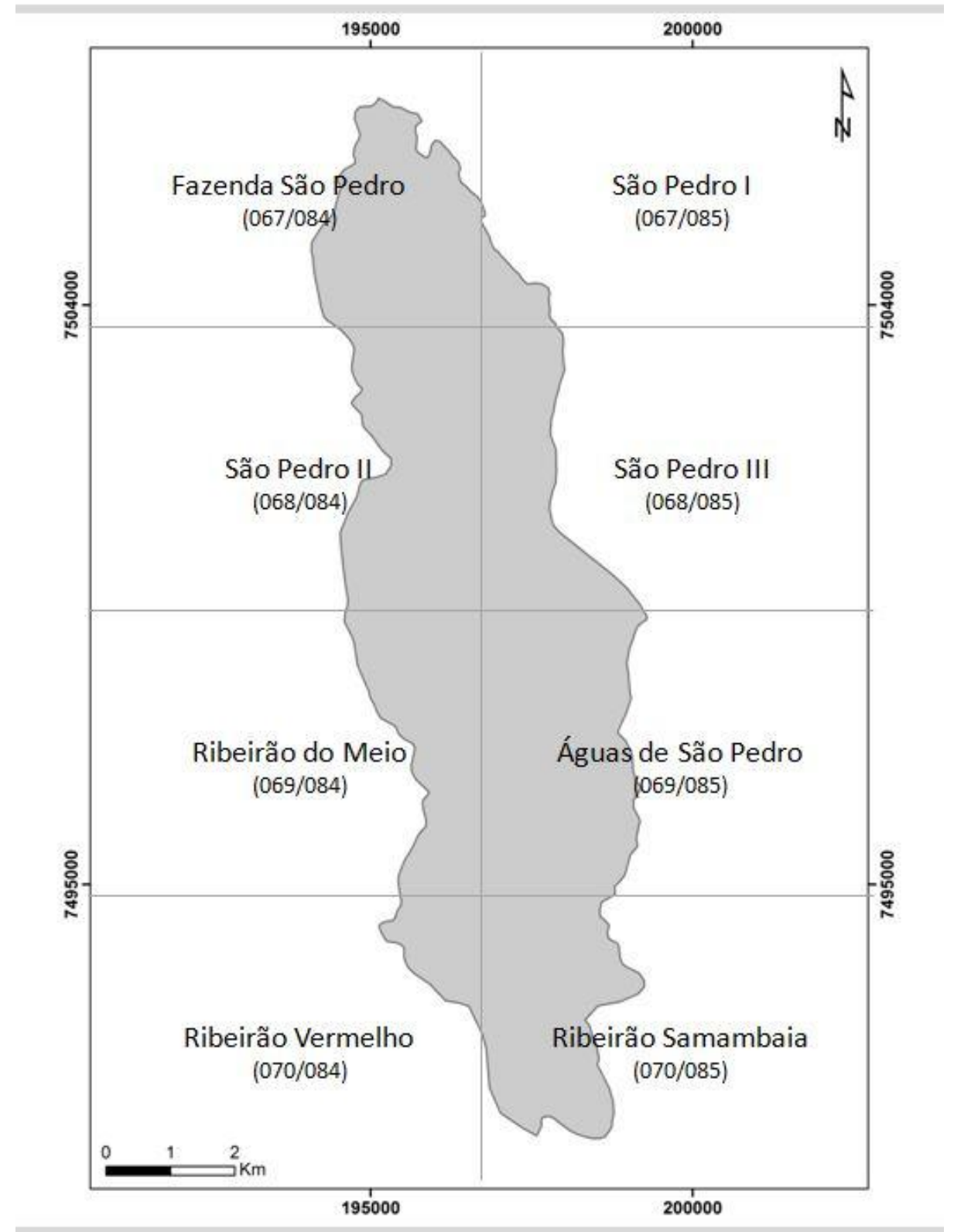

\subsubsection{Sensoriamento Remoto}

Inicialmente foi realizado a compilação das feições erosivas localizadas nas Subbacias dos Córregos dos Alpes e Retiro, mapeadas por Araújo (2011) na escala de 1:15.000. Através da interpretação das imagens de satélites atuais foi observada a situação atual destas feições, com a finalidade de complementar as informações obtidas pelo autor.

As etapas seguintes compreenderam o mapeamento das demais feições localizadas na Bacia do Córrego do Meio, utilizando imagens de satélite de 2016 (SPOT/Pléiades) e também ortofotos da Emplasa (Tabela 18). Na plataforma do Google Earth Pro, foram identificadas as coordenadas UTM de cada uma das feições, seguida pela sobreposição com as ortofotos para 
verificação dos dados levantados. As informações foram tabuladas no software Excel $^{\circledR} \mathrm{e}$ importadas para o $\operatorname{ArcGIS}^{\circledR} 10.3$, para processamento e análise dos dados.

Durante esta fase também foram levantadas informações sobre posição das feições no relevo; profundidade dos canais; e uso e ocupação do local, para isto foram utilizados os mapas de landforms, mapa de uso e ocupação e as ortofotos, que auxiliaram na determinação remota destes dados.

Tabela 18 - Característica das ortofotos.

\begin{tabular}{c|c}
\hline \multicolumn{2}{c}{ Ortofotos Emplasa } \\
\hline Resolução & 1 metro \\
\hline Aquisição & 2011 \\
\hline Câmera & Ultracam - Modelo X e XP \\
\hline Aeronaves & Turboélice Carajá/Jato Lear Jet \\
\hline Composição Cores & RGB \\
\hline
\end{tabular}

Fonte: Mapeia São Paulo (2017).

\subsubsection{Processamento dos dados em SIG}

Esta etapa compreendeu a elaboração de produtos cartográficos básicos em escala de 1:20.000 no software ArcGIS ${ }^{\circledR} 10.3$.

\subsubsection{Modelo Digital de Elevação (MDE)}

O Modelo Digital de Elevação foi elaborado a partir de curvas de nível, pontos cotados e rede de drenagem, compilados das cartas topográficas do IGC (1979). É importante ressaltar que a rede de drenagem deve apresentar os canais digitalizados de maneira adequada, isto é, devem estar conectados da nascente até a foz, favorecendo a representação correta dos valores de elevação.

A ferramenta utilizada para interpolação destes dados foi "3D Analyst Tools - Raster Interpolation - Topo to raster" (HUTCHINSON, 1988 e 1989), e se baseia na técnica de interpolação iterativa de diferenças finitas. Foram usados três tamanhos de pixels para os dados de saída, 2, 10 e 30 metros, com a finalidade de analisar a resolução mais adequada para obtenção dos parâmetros morfométricos: área de contribuição e declividade média.

Após a obtenção dos arquivos, foi aplicado um filtro "Spatial Analyst Tools Neighborhood - Filter" para remoção das depressões (sinks). Realizou-se a validação qualitativa dos modelos produzindo as curvas de nível de maneira automática a partir da 
ferramenta "3D Analyst Tools - Raster Surface - Contour". Os arquivos foram comparados visualmente com as curvas de nível digitalizadas das cartas topográficas do IGC (1979).

\subsubsection{Carta de Declividades}

As Cartas de Declividades foram elaboradas por meio da ferramenta " $3 D$ Analyst Tools - Raster Surface - Slope” utilizando diferentes tamanhos de pixel, 2, 10 e 30 metros, assim como os MDE. Para cada célula do arquivo matricial, a ferramenta identifica as variações decorrentes dos valores de altitude (z) que indicam o valor da declividade pixel a pixel, em percentuais ou graus. As classes adotadas foram definidas conforme as recomendações do IG (1993), estabelecidas em função das características do terreno (Tabela 19).

Tabela 19 - Definição das classes de declividade.

\begin{tabular}{|c|c|}
\hline Classes $(\%)$ & Características \\
\hline $0-2$ & Terrenos planos ou quase planos, onde o escoamento superficial é muito lento ou lento. \\
\hline $2-5$ & $\begin{array}{l}\text { Terrenos com declividades suaves nos quais o escoamento superficial é lento ou médio e os } \\
\text { problemas de erosão requerem práticas simples de conservação. }\end{array}$ \\
\hline $5-10$ & $\begin{array}{l}\text { Terrenos inclinados, geralmente com relevo ondulado, nos quais o escoamento superficial é médio } \\
\text { e rápido, porém com poucos problemas de erosão superficial. }\end{array}$ \\
\hline $10-15$ & $\begin{array}{l}\text { Terrenos muito inclinados, ou colinosos, onde o escoamento superficial é rápido. Apresentam } \\
\text { problemas de erosão superficial, exceto quando ocorrem em solos permeáveis e pouco arenosos. }\end{array}$ \\
\hline $15-20$ & Terrenos inclinados onde o escoamento superficial é rápido, com problemas de erosão superficial. \\
\hline $20-25$ & $\begin{array}{l}\text { Terrenos fortemente inclinados com escoamento superficial muito rápido, susceptível a ocorrência } \\
\text { de processos erosivos. }\end{array}$ \\
\hline $25-50$ & $\begin{array}{l}\text { Terrenos fortemente inclinados a muito íngremes, com escoamento superficial muito rápido e com } \\
\text { desenvolvimento de solo raso a muito raso. Susceptível a ocorrência de processos erosivos, } \\
\text { sujeitos a movimentos de massa e queda de blocos. }\end{array}$ \\
\hline$>50$ & $\begin{array}{l}\text { Terrenos muito íngremes ou escarpados, com desenvolvimento de solos muito rasos, com } \\
\text { exposição da rocha; extremamente susceptível a erosão. }\end{array}$ \\
\hline
\end{tabular}

\subsubsection{3 Área de contribuição}

Para elaboração dos mapas de área de contribuição foram utilizados dois algoritmos, com o objetivo de analisar a viabilidade de cada um dos modelos de fluxo: D8 - Determinisc eight-neighbors (O’CALLAGHAN; MARK, 1984) e D-Infinity (TARBOTON, 1997). O D8 determina a direção de fluxo a partir das diferenças de cotas existentes entre os oito pixels vizinhos, e o D-Infinity considera infinitas possibilidades de direção de fluxo, distribuídas proporcionalmente entre os pixels (Figura 37). 
Figura 37 - Métodos para determinar as direções de fluxo.

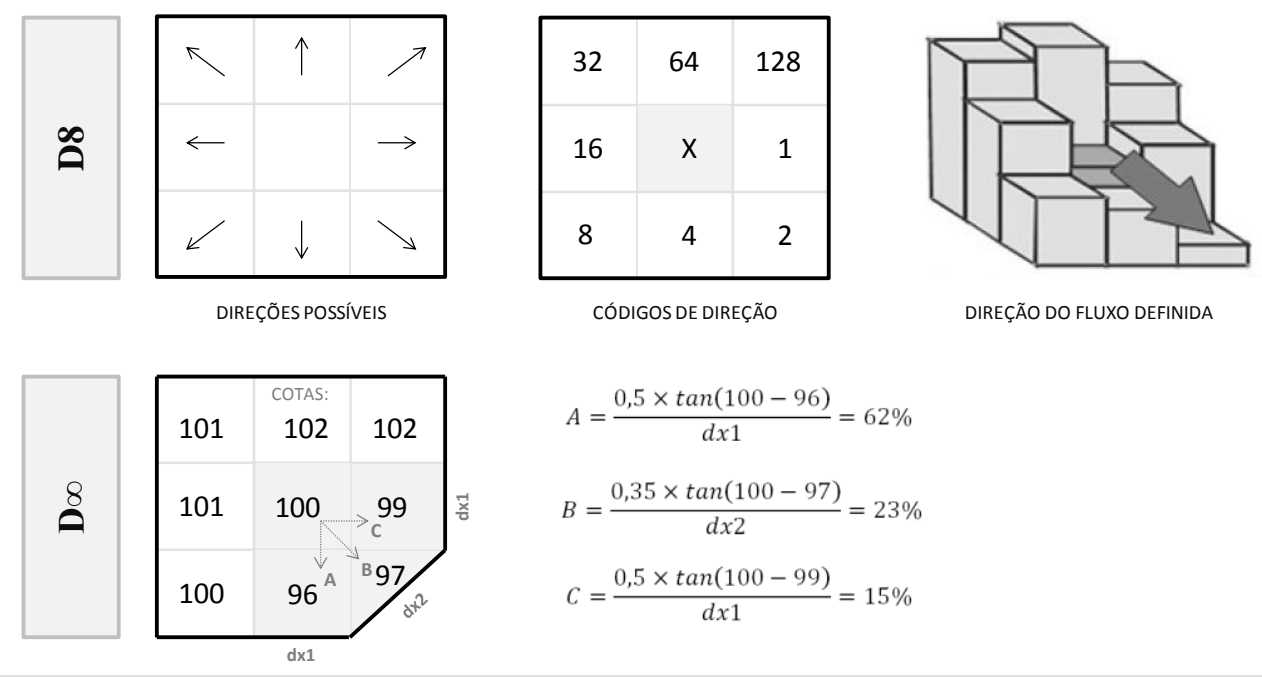

Fonte: Adaptado de Bosquilia et al. (2014).

A elaboração dos mapas de área de contribuição deve ser realizada em etapas, conforme o fluxograma da Figura 38. Para aplicação do D8 utilizou-se as ferramentas do "Spatial Analyst Tools - Hydrology", o "Fill" remove as imperfeições (sinks) que surgem devido à resolução dos dados ou aproximação dos valores de elevação para o número inteiro mais próximo; o "Flow Direction" gera o mapa com as oito direções de fluxo; e com base neste último arquivo define-se o fluxo acumulado para cada pixel do raster de entrada.

$\begin{array}{llllll}\text { Quando ao D-Infinity utilizou-se } & \text { o software } & \text { TauDEM }^{\circledR} & 5.1 .2\end{array}$ (Terrain Analysis Using Digital Elevation Models), como extensão do ArcToolbox - ArcGIS. Os arquivos gerados a cada etapa (Pit, D-Infinity flow direction e D-Infinity contributing area) segue o mesmo princípio das ferramentas do "Hydrology", porém com algoritmos de interpolação diferentes.

Figura 38 - Etapas para elaboração do mapa de área de contribuição.

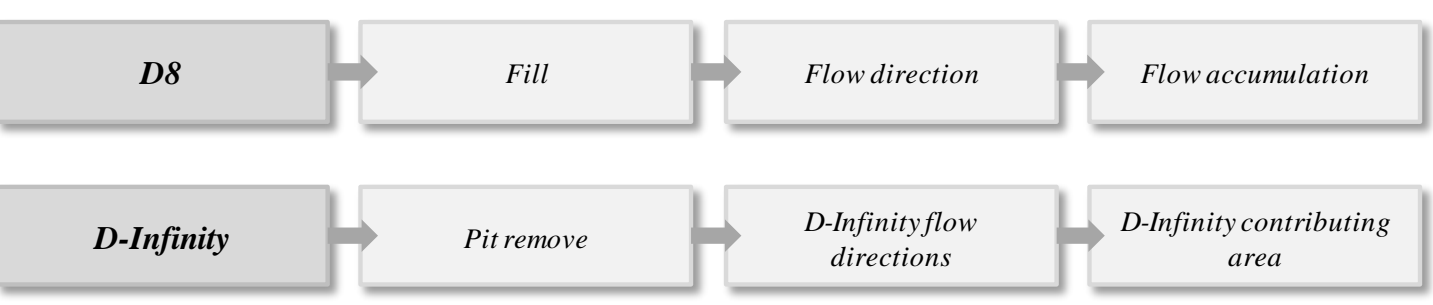

No software TauDEM ${ }^{\circledR}$ utilizou-se também a ferramenta "D-Infinity Upslope Dependece", que quantifica os pixels que contribuem para um determinado ponto, de acordo com a direção de fluxo. Para isto, inicialmente foi criada uma matriz regular, onde se atribuiu 
valor igual à "1" ao pixel de destino, sendo este o ponto de cabeceira das feições, e valor " 0 " aos demais pixels. A Figura 39 apresenta um esquema destes algoritmos.

Figura 39 - Representação da ferramenta "D-Infinity Upslope Dependence".

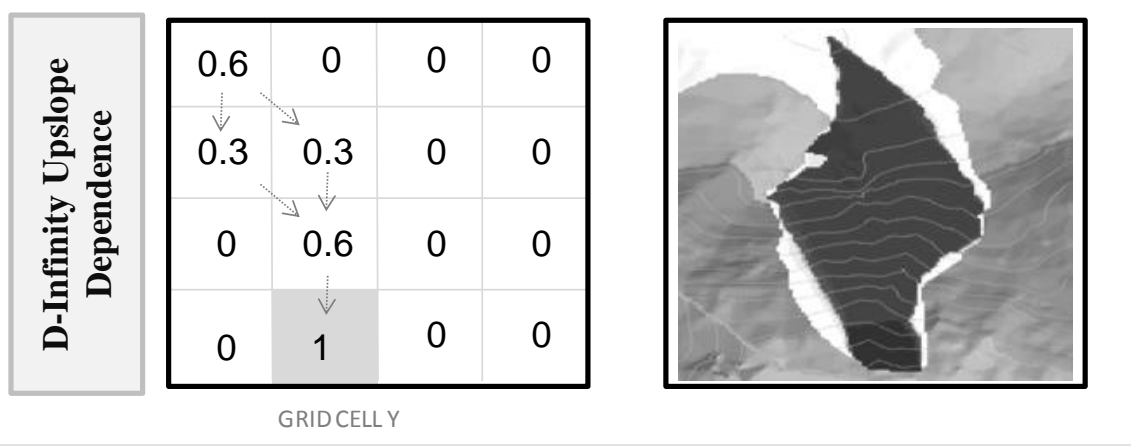

Fonte: Adaptado de TauDEM (2016).

Os mapas de fluxo acumulado obtidos (D8 e D-Infinity) foram validados por meio da obtenção da rede de drenagem automática, que foi comparada com a digitalizada da carta topográfica do IGC (1979).

\subsection{4 Índices $S x A$}

A elaboração dos índices SxA foi realizada em duas etapas: a primeira, compreendeu a geração para os mesmos pontos de feições erosivas mapeadas por Araújo (2011), localizadas nas Sub-Bacias dos Córregos dos Alpes e Retiro, com o objetivo de comparar os índices obtidos em função do algoritmo de fluxo acumulado. A segunda etapa consistiu na aplicação do índice para todas as erosões da Bacia do Córrego do Meio, mapeadas no presente trabalho e também por Araújo (2011).

Os parâmetros declividade média (S) e área de contribuição (A) foram obtidos a partir dos mapas elaborados na etapa anterior (Item 4.2.3). Os arquivos matriciais do fluxo acumulado foram convertidos para "shapefile" e as respectivas áreas calculadas em hectares (ha). Para obtenção da declividade média foi realizado um recorte da Carta de Declividade (Data Management Tools - Raster - Raster Processing - Clip), considerando a área de contribuição de cada feição, sendo os dados que estavam em valores percentuais, convertidos para $\mathrm{m} . \mathrm{m}^{-1}$. As informações obtidas foram organizadas em planilhas, e os gráficos foram elaborados no Excel.

Para definir os limiares críticos (thresholds) topográficos a partir da relação SxA proposta por Patton e Schum (1975), descrita na Equação 8 foi utilizado o software Excel $^{\circledR}$. Os dados 
de declividade média (S) e área de contribuição (A) de cada uma das feições foram plotados no plano cartesiano e calculou-se uma linha de regressão, com a função potência (Power Function).

$$
S=a A^{-b}
$$

O ajuste da linha de regressão para o limiar inferior dos dados analisados, representando o limite crítico das feições erosivas, foi realizado de maneira empírica. Após obter a equação da reta, calculou-se um novo valor para o coeficiente " $a$ " a partir das coordenadas do ponto mais próximo do limiar crítico. Autores como Vanwalleguem et al. (2005) e Stabile (2013) realizaram este mesmo procedimento para determinar o limiar de desencadeamento das feições. A Figura 40 apresenta um exemplo hipotético deste ajuste.

Figura 40 - Exemplo de ajuste do limiar topográfico.

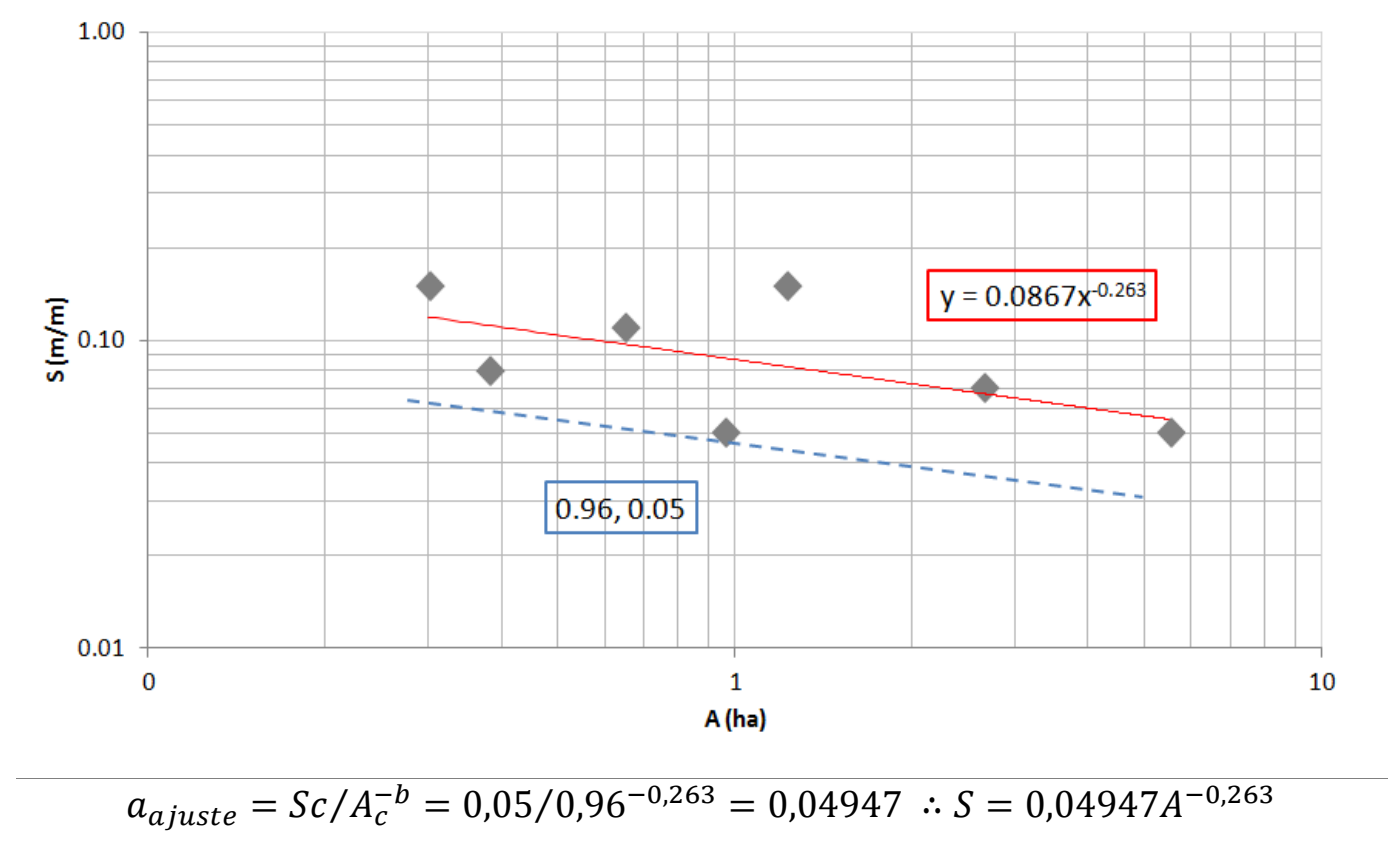

Após a obtenção dos índices SxA para a Bacia do Córrego Meio, analisou-se as características específicas de cada uma das feições, como posicionamento no relevo, uma vez que os valores dos coeficientes " $a$ " e " $b$ " dependem das características do ambiente. A análise foi realizada com o intuito de classificar as feições erosivas em grupos com características similares, permitindo um melhor ajuste dos dados. 


\subsubsection{Zoneamento de áreas críticas de processos erosivos}

A partir dos índices SxA obtidos foram elaboradas as Cartas de Zoneamento de Áreas de Ocorrência de Processos Erosivos, em escala 1:20.000, que representa as áreas críticas e instáveis. Foi utilizada a ferramenta "Spatial Analyst Tools - Map Algebra - Raster Calculator", que permite a aplicação de expressões algébricas em arquivos matriciais.

A Equação 9 apresenta a expressão utilizada, no qual foram inseridos como parâmetro de entrada a Carta de Declividades e o Mapa de Fluxo Acumulado (D-Infinity) da Bacia do Córrego do Meio. O resultado deste processamento consiste em um raster com pixels cujos valores são 0 e 1 , sendo que, os pixels com valor igual a 0 estão abaixo do limiar crítico, e os pixels com valores iguais a 1 são aqueles que estão acima do limiar crítico, são os que representam as áreas críticas onde ocorrerá a formação de canais de erosão.

$$
\text { declividade } \geq a *(\text { fluxoacumulado } * *(-b))
$$

A Figura 41 ilustra o processamento realizado nesta etapa, na qual é possível observar que a carta de zoneamento consiste em arquivo matricial que representa para cada pixel a relação entre a declividade e o fluxo acumulado.

Figura 41 - Processamento para elaboração da carta de zoneamento.

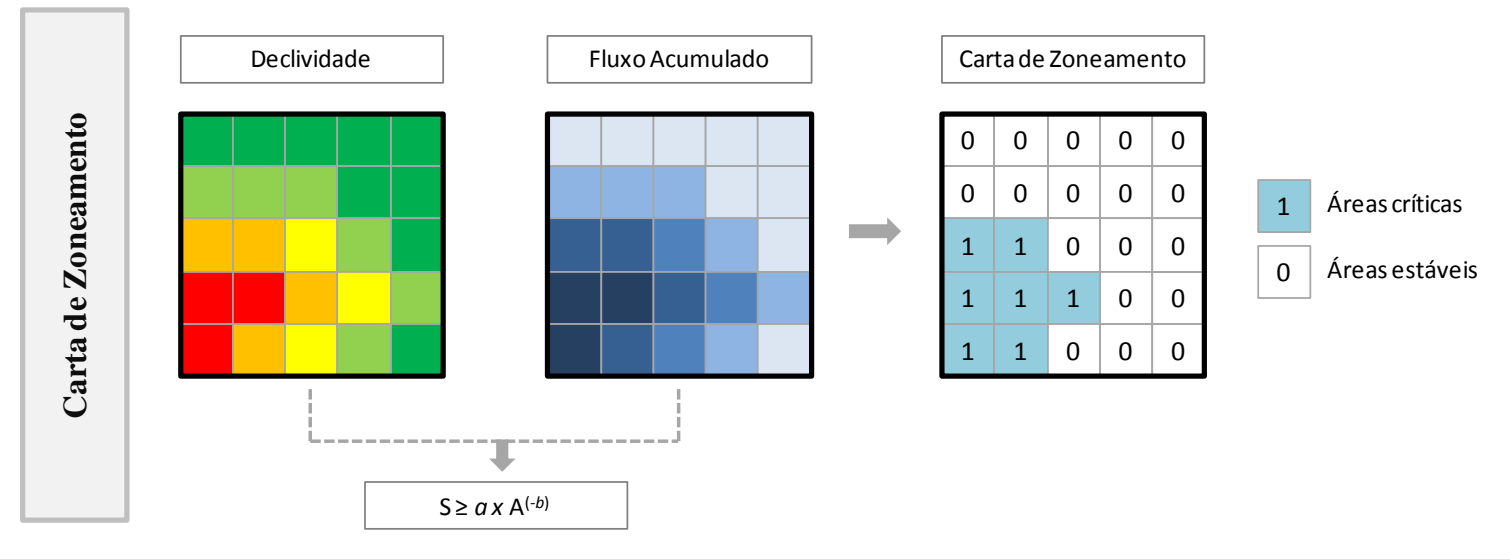

Como forma de verificar a compatibilidade dos resultados obtidos a partir da relação $\mathrm{S} x \mathrm{~A}$ com documentos cartográficos elaborados previamente, utilizou-se a Carta de Susceptibilidade à Erosão elaborada por Gomes (2002), para a Bacia do Córrego do Meio na escala de 1:20.000. Para analisar os dados em ambiente SIG (ArcGIS ${ }^{\circledR}$ ), inicialmente foi 
realizado o georreferenciamento e digitalização da carta, uma vez que o arquivo estava disponível no formato .jpg, o que não permitia a realização dos processamentos necessários.

Desta forma, para realizar a tabulação cruzada entre as Cartas de Zoneamento e Carta de Susceptibilidade, utilizou-se a ferramenta "Spatial Analyst Tools - Zonal - Tabulate Area" a fim de verificar a correlação existente entre as áreas críticas e susceptíveis, analisando os valores equivalentes $\mathrm{em}^{\mathrm{km}} \mathrm{e}^{2} \%$. Tais valores foram plotados e analisados graficamente no software Excel $^{\circledR}$. 



\section{Resultados}

Os resultados iniciais apresentados neste capítulo são os documentos cartográficos básicos que foram utilizados para caracterização da Bacia do Córrego do Meio, e os mapas obtidos pelo processamento em SIG - MDE, Carta de Declividades e Mapas de Fluxo de Acumulado - planos de informações básicos para o desenvolvimento do trabalho.

Nos próximos itens deste capítulo são apresentados os resultados para a Sub-bacia do Córrego dos Alpes e Retiro: interferência da resolução espacial, comparação entre D8 e DInfinity, e índices SxA. Por fim são apresentados os resultados referentes ao objetivo geral deste trabalho, para a Bacia do Córrego do Meio: índices SxA e Carta de Zoneamento de Áreas de Ocorrência de Processos Erosivos.

\subsection{Documentos Cartográficos}

\subsubsection{Mapa de Documentação}

O Mapa de Documentação da Bacia do Córrego do Meio apresenta todas as informações reunidas durante o desenvolvimento do trabalho, como pode ser observado na Figura 42.

- As Curvas de nível, rede de drenagem e pontos cotados foram obtidas por meio dos Mapas Topográficos 1:10.000 (IGC, 1979). Estes arquivos foram importados para o Banco de Dados da Bacia do Córrego do Meio, e convertidos para o sistema de projeção UTM "SIRGAS 2000 - Zona 23 S”, com o auxílio de ferramentas do ArcGIS;

- Os pontos de feições erosivas localizados nas Sub-bacias dos Córregos dos Alpes e Retiro foram compilados do trabalho desenvolvido por Araújo (2011), em escala de 1:10.000, totalizando 35 pontos de feições do tipo sulcos, ravinas e voçorocas, locados em área de encostas ou drenagem. Os pontos mapeados neste trabalho com o auxílio de imagens de satélites e ortofotos consistem em 23 feições erosivas do tipo sulcos, ravinas e voçorocas.

Verifica-se que parte da área urbana do município de São Pedro - SP está inserida na Bacia do Córrego do Meio, que se caracteriza pela presença de chacreamentos e ruas não 
pavimentadas, que por sua vez, podem contribuir para o surgimento e evolução de feições erosivas. As informações para cada um dos pontos de feições erosivas localizados na área em estudo como tipo, profundidade, localização, e uso e ocupação está descrita na Tabela 20. 
Figura 42 - Mapa de documentação da Bacia do Córrego do Meio.

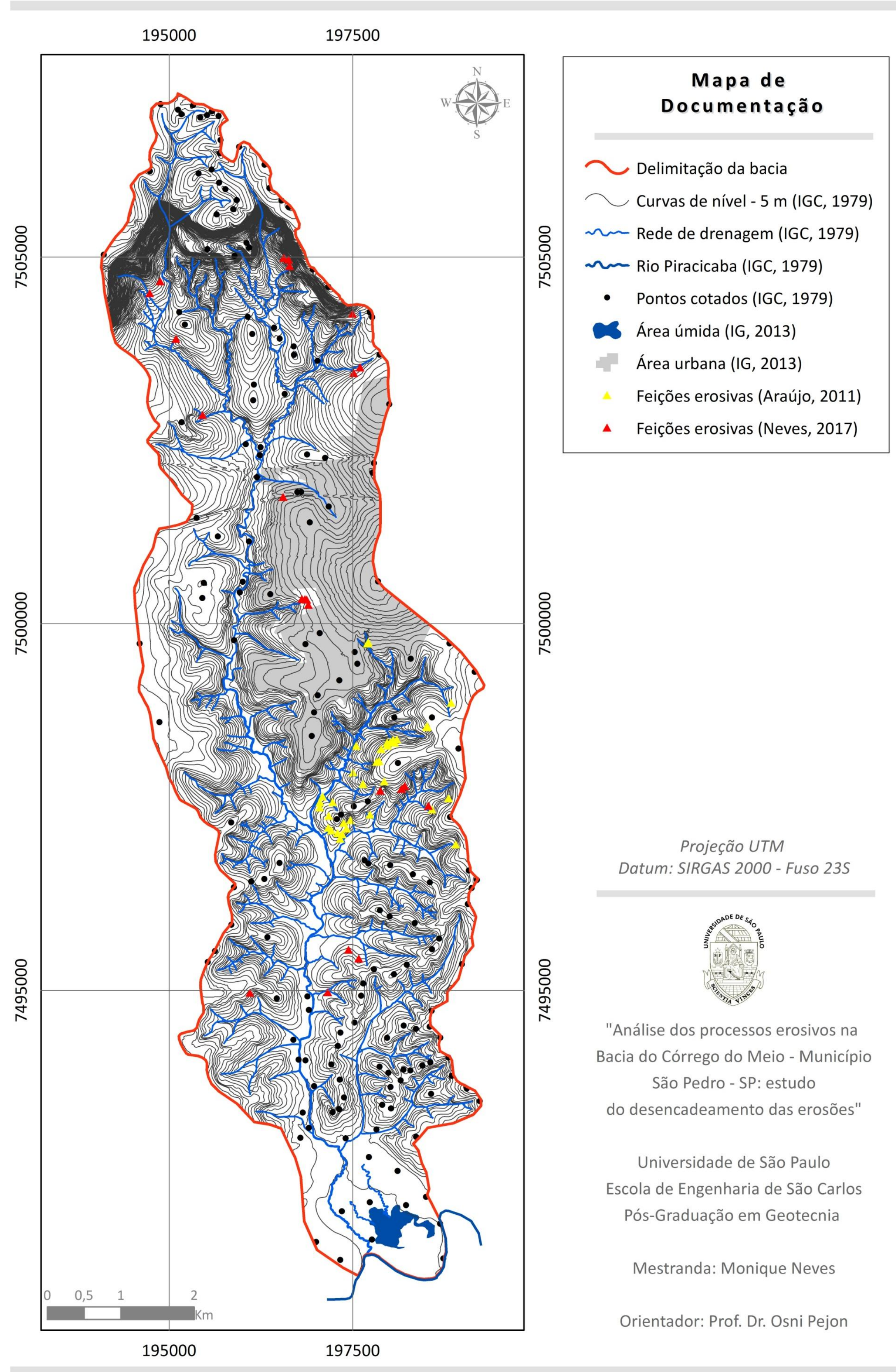



Tabela 20 - Pontos de feições erosivas da Bacia do Córrego do Meio (Continua).

\begin{tabular}{|c|c|c|c|c|c|c|c|c|c|c|}
\hline $\mathbf{N}^{\mathbf{o}}$ & $\mathbf{X}$ & $\mathbf{Y}$ & po & (m) & Posição $^{(*)}$ & $\mathbf{I}$ & $\left(\mathbf{m}^{2}\right)$ & $\begin{array}{c}S \\
(\%)\end{array}$ & $\begin{array}{c}\text { Uso } \\
(2011)\end{array}$ & $\begin{array}{c}\text { Uso } \\
(2016)\end{array}$ \\
\hline 1 & & 0 & & & & & & & & \\
\hline 2 & 095 & 03886 & & 1,5 & Drenagem & $\mathrm{PP}(5<\mathrm{e}<$ & & 23 & & \\
\hline 3 & & 504510 & & & Drenagem & & & 35,38 & & \\
\hline 4 & & 501732 & & & & TFP $(2<\mathrm{e}$ & & 5,59 & & \\
\hline 5 & 196851 & 500337 & Voçoroca & & Drenagem & $\mathrm{TFP}(5<\mathrm{e}<10)$ & & 6,16 & & \\
\hline 6 & & 31 & & & & $5<e<10)$ & & 6,27 & & \\
\hline 7 & 196899 & 500261 & & & & $\mathrm{TFP}(5<\mathrm{e}<10)$ & & 6,8 & & \\
\hline 8 & 96810 & 500340 & & & Drenagem & TFP $(5<\mathrm{e}<10)$ & & 5,85 & & \\
\hline 9 & & 497750 & & & & & & 3,62 & & \\
\hline 10 & & 497788 & & & & & & 1,34 & & \\
\hline 11 & & & & & & & & & & \\
\hline 12 & 196562 & 504990 & & & & & & & & \\
\hline 13 & 96629 & & & & & & & & & \\
\hline 14 & & & & & & & & & & \\
\hline 15 & 195456 & & & & Drenagem & & & & & \\
\hline 16 & & & & & & & & & & \\
\hline 17 & 197445 & 7495556 & & $<0,5$ & ncosta & & & 8,83 & & Cana \\
\hline 18 & & & & & & & & & & \\
\hline 19 & & & & & & & & 10,87 & & \\
\hline & & & & & & & & & & \\
\hline 21 & & & & & & & & & $\mathrm{em}$ & 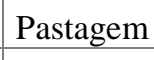 \\
\hline 22 & 196103 & 7494969 & ulco & & ncosta & & & 9,68 & & Cana \\
\hline 23 & & & & & & & & & & \\
\hline 24 & 197247 & 497193 & & & & & & 12,71 & $\mathrm{~m}$ & \\
\hline & & & & & & & & & & \\
\hline 26 & & & & & & & & & & \\
\hline 27 & & & & & & & & & & \\
\hline 28 & & & & & & & & & & \\
\hline & & & & & & & & & & \\
\hline 30 & & & & & & & & & & \\
\hline 31 & & & & & & & & & & \\
\hline 32 & & & & & & & & . & & Cana \\
\hline 33 & & & & & & TFP $(2<\mathrm{e}<5)$ & & & $\mathrm{P}$ & $\mathrm{Pa}$ \\
\hline 34 & & & & & & & & & & a \\
\hline 35 & 198048 & 7498402 & & & costa & & & 7,46 & & Cana \\
\hline & 98089 & 7498429 & & & & $111(2-2)$ & & & & Ina \\
\hline 37 & 198133 & 7498432 & & & Encosta & TFP $(2<\mathrm{e}<5)$ & 8750,66 & 7,69 & Pas & na \\
\hline & & & & & & & & & & Urbano \\
\hline 39 & 197703 & 7499727 & Voçoroca & & Drenagem & TFP $(5<\mathrm{e}<10)$ & & & Urbano & ano \\
\hline & 197961 & 7497861 & & & $\mathrm{a}$ & TFP $(5<\mathrm{e}<10)$ & & & $\mathrm{m}$ & na \\
\hline 41 & 197737 & 749739 & Ravina & 1 a 1,5 & $\mathrm{em}$ & DCD & 6929,81 & 20,23 & pto & $\mathrm{Eu}$ \\
\hline
\end{tabular}




\begin{tabular}{|c|c|c|c|c|c|c|c|c|c|c|}
\hline $\mathbf{N}^{\mathbf{o}}$ & $\mathbf{X}$ & $\mathbf{Y}$ & Tipo & $\mathbf{P}(\mathbf{m})$ & Posiçãa $^{(*)}$ & M.I. & $\mathbf{A}\left(\mathbf{m}^{2}\right)$ & $\begin{array}{c}S \\
(\%)\end{array}$ & $\begin{array}{c}\text { Uso } \\
(2011)\end{array}$ & $\begin{array}{c}\text { Uso } \\
(2016)\end{array}$ \\
\hline 42 & 198841 & 7498924 & Voçoroca & 1 a 1,5 & Drenagem & TFP $(5<\mathrm{e}<10)$ & 25606,38 & 4,65 & Pastagem & Pastagem \\
\hline 43 & 198513 & 7498592 & Ravina & 0,5 a 1 & Encosta & TFP $(5<\mathrm{e}<10)$ & 11081,00 & 5,58 & Pastagem & Cana \\
\hline 44 & 197550 & 7498336 & Ravina & 1 a 1,5 & Drenagem & SA & 13542,94 & 14,9 & Pastagem & Pastagem \\
\hline 45 & 197508 & 7497974 & Ravina & 1 a 1,5 & Drenagem & RFP & 3603,52 & 17,06 & Pastagem & Pastagem \\
\hline 46 & 197642 & 7497816 & & 1 a 1,5 & Drenagem & TFP $(2<\mathrm{e}<5)$ & 9479,51 & 18,05 & Pastagem & Pastagem \\
\hline 47 & 198515 & 7498607 & Ravina & 0,5 a 1 & Encosta & TFP $(5<\mathrm{e}<10)$ & 10857,08 & 5,32 & Pastagem & Cana \\
\hline 48 & 197081 & 7497501 & Ravina & & Encosta & & & 11,55 & Pastagem & Pastagem \\
\hline 49 & 197355 & 7497061 & Sulco & $<0,5$ & Encosta & RFP & 3545,49 & 12,39 & Pastagem & Pastagem \\
\hline 50 & 197331 & 7497133 & Sulco & $<0,5$ & Encosta & RFP & 2173,00 & 11,58 & Pastagem & Pastagem \\
\hline 51 & 197389 & 7497097 & Sulco & & Encosta & RFP & & 13,43 & Pastagem & Pastagem \\
\hline 52 & 197452 & 7497214 & Sulco & $<0,5$ & Encosta & RFP & 3062,95 & 14,83 & Pastagem & Pastagem \\
\hline 53 & 197859 & 7498117 & Sulco & $<0,5$ & Encosta & TFP $(5<\mathrm{e}<10)$ & 6075,18 & 8,81 & Pastagem & Pastagem \\
\hline 54 & 197865 & 7498135 & Sulco & $<0,5$ & Encosta & $\operatorname{TFP}(5<\mathrm{e}<10)$ & 5646,13 & 7,02 & Pastagem & Pastagem \\
\hline 55 & 198934 & 7497003 & Ravina & 1 a 1,5 & Drenagem & TFP $(2<\mathrm{e}<5)$ & 5857,95 & 14,21 & Pastagem & Pastagem \\
\hline 56 & 198831 & 7497627 & Ravina & 0,5 a 1 & Encosta & TFP $(2<\mathrm{e}<5)$ & 4094,17 & 15,82 & Pastagem & Pastagem \\
\hline 57 & 197996 & 7498365 & Sulco & $<0,5$ & Encosta & TFP $(2<\mathrm{e}<5)$ & 4155,69 & 7,7 & Pastagem & Cana \\
\hline 58 & 198100 & 7498393 & Sulco & $<0,5$ & Encosta & TFP $(2<\mathrm{e}<5)$ & 7972,79 & 6,43 & Pastagem & Cana \\
\hline
\end{tabular}

Legenda

${ }^{(*)}$ Posição no relevo; P - Profundidade; M.I. Materiais inconsolidados; A - Área de contribuição; S - Declividade média; Uso - Uso do solo; RFP - Residual formação pirambóia; SA - Sedimentos aluvionares; SC: Sedimentos coluvionares; TFP - Transportado formação piramboia; e - espessura;

\subsubsection{Mapas Geológicos-Geotécnicos}

Os mapas geológico-geotécnicos foram compilados do trabalho de Gomes (2002) que também desenvolveu sua pesquisa na Bacia do Córrego do Meio, na escala de 1:20.000.

\subsubsection{Mapa de Landforms}

O Mapa de Landforms consiste na representação das porções do terreno decorrentes de processos naturais, com base em características próprias do local, como: forma e posição topográfica, frequência e organização dos canais, inclinação das vertentes e amplitude do relevo (LOLLO, 1995).

Gomes (2002) elaborou o Mapa de Landforms da Bacia do Córrego do Meio utilizando técnicas de Sensoriamento Remoto, para identificar as especificações do terreno, e trabalho de campo, para confirmação e caracterização das informações analisadas. As unidades de landforms foram definidas considerando o tipo de material geológico, relevo e padrões de drenagem. A área em estudo é composta por três sistemas: A - área de planalto; B 
- escarpas com declividades elevadas e sopé de talude com material colúvio e tálus; e C - área de depressão. A Tabela 21 apresenta uma síntese das características das unidades.

Tabela 21 - Características dos sistemas e unidades de landforms.

\begin{tabular}{|c|c|c|}
\hline$S^{(*)}$ & $\boldsymbol{U}^{(* *)}$ & Características \\
\hline$A$ & - & $\begin{array}{l}\text { Planalto com encostas suavemente onduladas e extensas, de topos planos, associados a vales } \\
\text { de pequena amplitude e expressão geográfica; drenagem de baixa densidade e sinuosidade } \\
\text { mista; materiais laterizados com maior resistência aos processos de intemperismo; presença } \\
\text { de feições erosivas do tipo sulco e ravina; }\end{array}$ \\
\hline \multirow{3}{*}{$B$} & B1 & $\begin{array}{l}\text { Encostas íngremes, convexas e retilíneas, associadas a topos irregulares e angulosos; } \\
\text { vertentes com perfis retilíneos, e vales dissecados de pequenas amplitudes; baixa frequência } \\
\text { de canais de drenagem e sinuosidade mista; presença de queda de blocos de rocha; }\end{array}$ \\
\hline & B2 & $\begin{array}{l}\text { Encosta do tipo em sequência a escarpa, situada entre as unidades B1 e B3; ausência de } \\
\text { cobertura vegetal e textura de relevo; material litológico resistente de textura clara; }\end{array}$ \\
\hline & B3 & $\begin{array}{l}\text { Unidade caracterizada por feições arrasadas, em terreno de declividade moderada a suave; } \\
\text { compreende zonas de colúvio e tálus; materiais inconsolidados bastante espesso e do tipo } \\
\text { arenoso; moderada frequência de canais de drenagem; }\end{array}$ \\
\hline \multirow{12}{*}{$C$} & $\mathrm{C} 1$ & $\begin{array}{l}\text { Unidade com baixa declividade associada à encostas retilíneas e côncavo-convexas, e de } \\
\text { topo suavemente arredondado; moderada frequência de canais; presença de sulcos, ravinas e } \\
\text { voçorocas às proximidades dos vales; solo susceptível à erosão; }\end{array}$ \\
\hline & $\mathrm{C} 2$ & $\begin{array}{l}\text { Formada por colinas amplas, de topos suavemente ondulados, e com vertentes de perfis } \\
\text { retilíneos a convexos; baixa densidade de canais de drenagem; presença de ravinas que } \\
\text { podem progredir a voçorocas; }\end{array}$ \\
\hline & C3 & $\begin{array}{l}\text { Colinas amplas de topos aplainados, vertentes com perfis retilíneos, declividade muito baixa } \\
\text { e canais de drenagem praticamente ausentes; presença de sulcos e ravinas; }\end{array}$ \\
\hline & $\mathrm{C} 4$ & $\begin{array}{l}\text { Terrenos baixos relativamente planos, situados as margens de rios sujeitos a inundações } \\
\text { periódicas; presença de ravinas que podem progredir a boçorocas gradualmente; }\end{array}$ \\
\hline & C5 & $\begin{array}{l}\text { Unidade com vales fechados com encostas retilíneas e convexas, associadas às planícies } \\
\text { aluviais; média a alta densidade de canais de drenagem com sinuosidade mista; presença de } \\
\text { sulcos e ravinas; }\end{array}$ \\
\hline & C6 & $\begin{array}{l}\text { Unidade formada por morrotes com vertentes convexas de topos arredondados a angulosos, e } \\
\text { declividade de relevo moderada; canais de drenagem que apresentam uma disposição } \\
\text { geométrica especifica, baixa densidade; }\end{array}$ \\
\hline & $\mathrm{C} 7$ & $\begin{array}{l}\text { Colinas associadas à encostas convexas de topos suavemente arredondados; padrão de } \\
\text { drenagem de densidade média a alta e sinuosidade mista; presença de cultivo de cana-de- } \\
\text { açúcar; }\end{array}$ \\
\hline & $\mathrm{C} 8$ & $\begin{array}{l}\text { Unidade de planície aluvial de terreno baixo, as margens de rios sujeitos à inundações; canais } \\
\text { de drenagem mais rasos e mais largos; densidade média e sinuosidade mista; presença de } \\
\text { margens erodidas devido ação da água fluvial; }\end{array}$ \\
\hline & C9 & $\begin{array}{l}\text { Superfície de relevo com feições arrasadas marcadas pela baixa densidade de drenagem, } \\
\text { sinuosidade mista; presença de sulcos e ravinas próximas às redes de drenagem; material } \\
\text { inconsolidado pouco susceptível à erosão; }\end{array}$ \\
\hline & $\mathrm{C} 10$ & $\begin{array}{l}\text { Colinas pequenas de topos suavemente ondulados, associada as vertentes côncavo-convexa } \\
\text { com declividades moderadas; moderada frequência de canais de drenagem; }\end{array}$ \\
\hline & $\mathrm{C} 11$ & $\begin{array}{l}\text { Unidade com relevo homogêneo e pequena declividade; presença de feições erosivas do tipo } \\
\text { em ravina e voçorocas; colinas médias a grandes topos suavemente ondulados, vertentes com } \\
\text { perfis retilíneos a convexos; e declividade baixa, associada a vales fechados; }\end{array}$ \\
\hline & $\mathrm{C} 12$ & $\begin{array}{l}\text { Unidade de planícies aluviais, com superfícies próximas as margens do Rio Piracicaba e } \\
\text { sujeita a constantes inundações; presença de lagos perenes ou intermitentes; não há presença } \\
\text { de feições do tipo ravina e voçorocas. }\end{array}$ \\
\hline
\end{tabular}

(*) Sistemas; (**) Unidades.

Fonte: Adaptado de Gomes (2002).

O sistema C está presente em $87 \%$ da Bacia do Córrego do Meio. Das unidades de landforms que compõem este sistema, aquela com maior predominância é a C2 (21,10\%), 
seguida pelas unidades C5 (10,53\%) e C6 (10,02\%) (Figura 43). As unidades C2 e C5 são constituídas por encostas de perfis retilíneos e convexos, que tendem a ser mais susceptíveis a ocorrência de processos erosivos, por apresentarem maior taxa de solo erodido, além disso, se caracterizam pela presença de feições, do tipo ravinas, que podem evoluir para processos mais complexos, como voçorocas. A Figura 43 apresenta o Mapa de Landforms da Bacia do Córrego do Meio.

Figura 43 - Percentual de ocorrência das unidades de landforms.

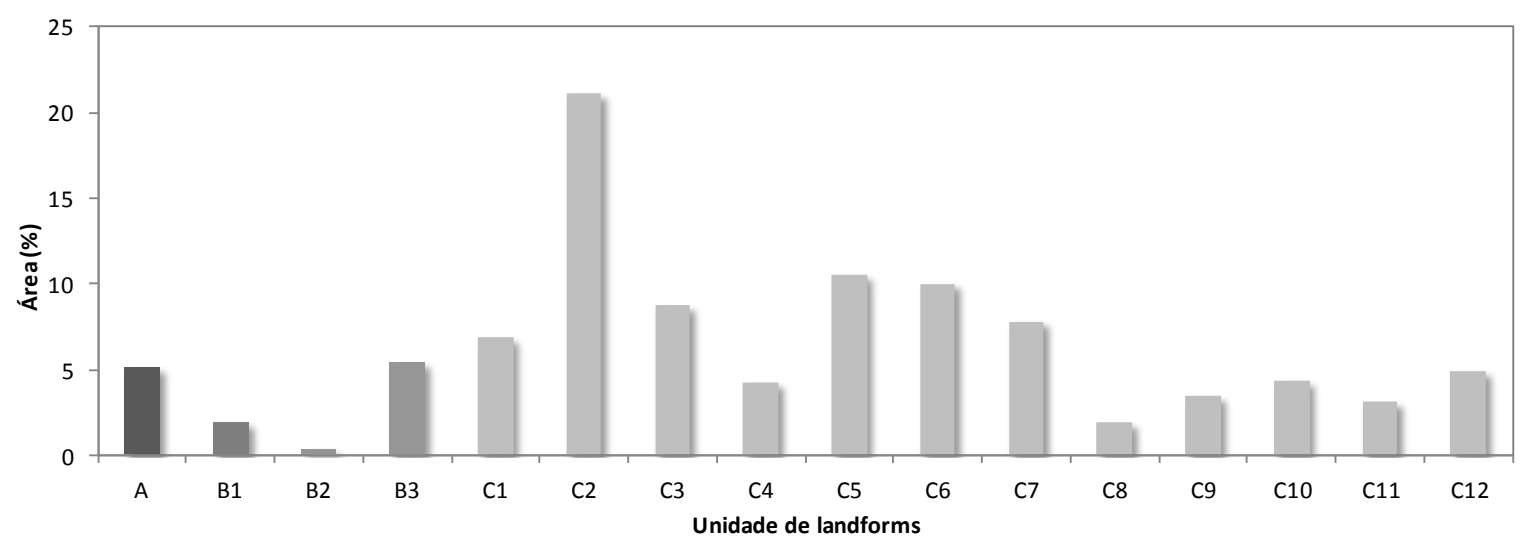


Figura 44 - Mapa de Landforms da Bacia do Córrego do Meio.

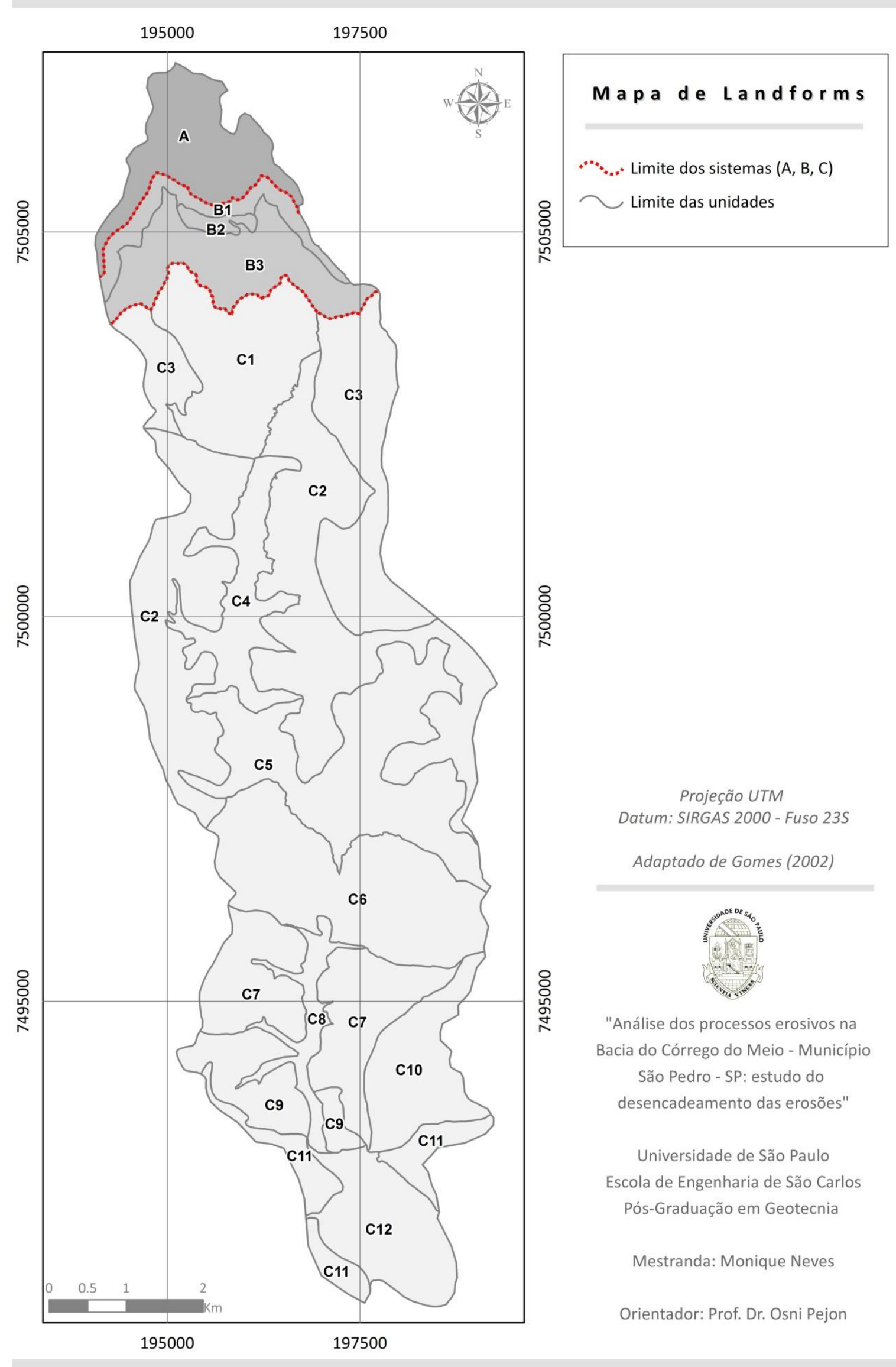


5.1.2.2 Mapa de Substrato Rochoso

A geologia da Bacia do Córrego do Meio é composta por rochas das Formações Itaqueri, Serra Geral, Botucatu e Pirambóia, como pode ser observado na Figura 45.

- Formação Pirambóia: representadas por arenitos finos a médios, de cores variegadas (vermelha, amarela, rosa e branca), siltitos, folhelhos, lamitos e conglomerados. Segundo Gomes (2002), observa-se a presença de estruturas do tipo plano-paralelas, estratificações cruzadas de médio porte, e presença de fraturas subverticais. Esta formação ocorre em $91,4 \%$ da área em estudo.

- Formação Botucatu: ocorre ao longo das escarpas e está associada as cuestas basálticas; os arenitos desta formação são de granulometria fina a média, silicificados e de coloração amarela, o que proporciona melhor sustentabilidade ao relevo. Estão presentes em $2,73 \%$ da bacia.

- Formação Serra Geral: ocorre também ao longo das escarpas, e de acordo com Gomes (2002) foi constatado a presença de derrames basálticos, de coloração cinza escura e textura afanítica, e diques de diabásio. Em termos percentuais correspondem a $0,75 \%$ da área.

- Formação Itaqueri: é composta litologicamente por arenitos grosseiros e conglomeráticos, e seixos de quartzitos de tamanho variado. Esta formação ocorre ao norte da bacia em estudo $(5,12 \%)$ no alto da Serra de São Pedro. 
Figura 45 - Mapa de Substrato Rochoso da Bacia do Córrego do Meio.

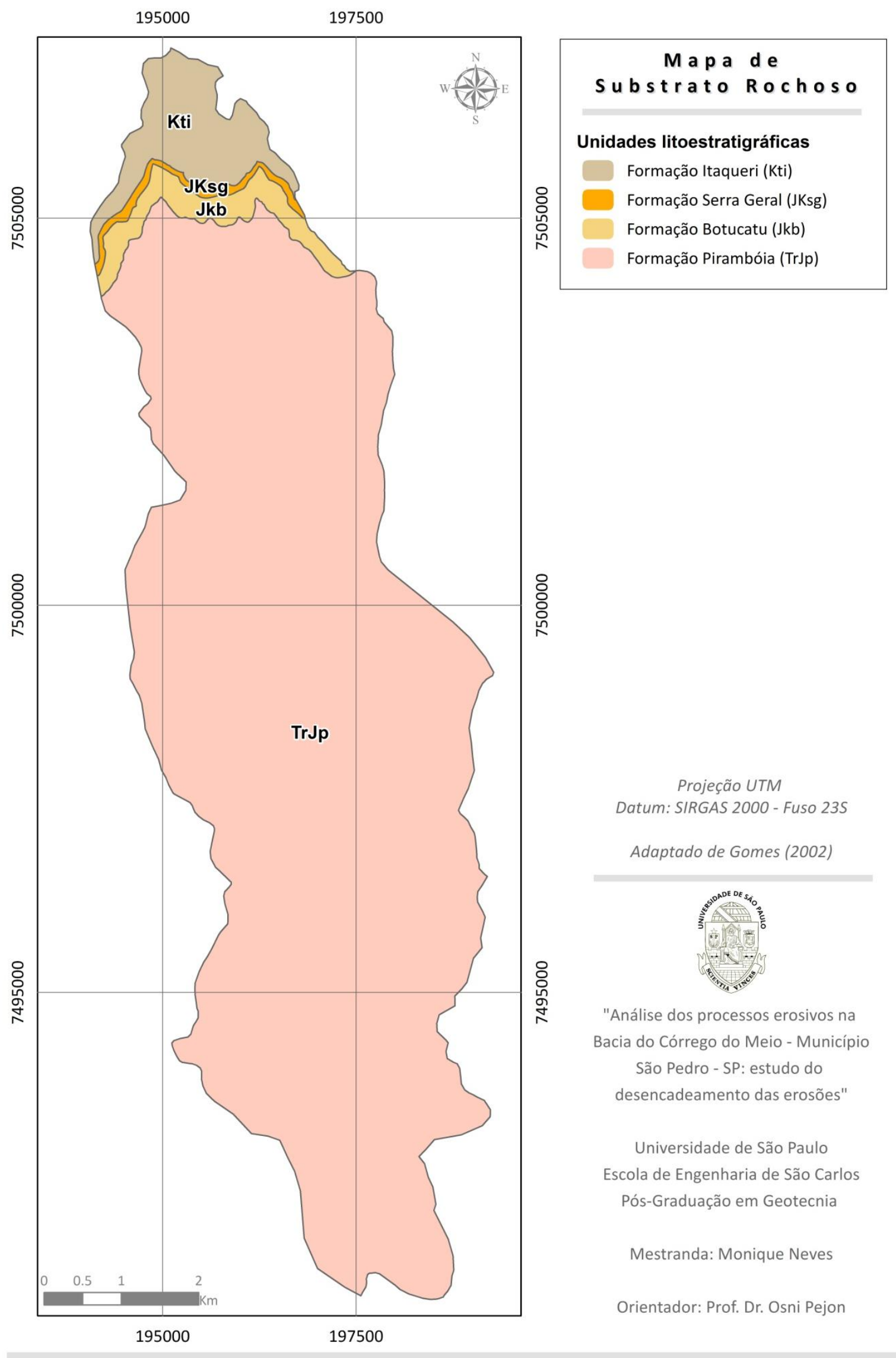


5.1.2.3 Mapa de Materiais inconsolidados

O Mapa de Materiais Inconsolidados retrata as diferentes unidades de materiais distinguidas conforme suas características geotécnicas. De acordo com Gomes (2002), a área em estudo é composta por 9 unidades, associadas as formações geológicas e suas diferentes espessuras, dentre estas, na Bacia do Córrego do Meio predominam os materiais Residuais da Formação Pirambóia e os Transportados Associados à Formação Pirambóia (Figura 46).

Figura 46 - Percentual de ocorrência das unidades de materiais inconsolidados.

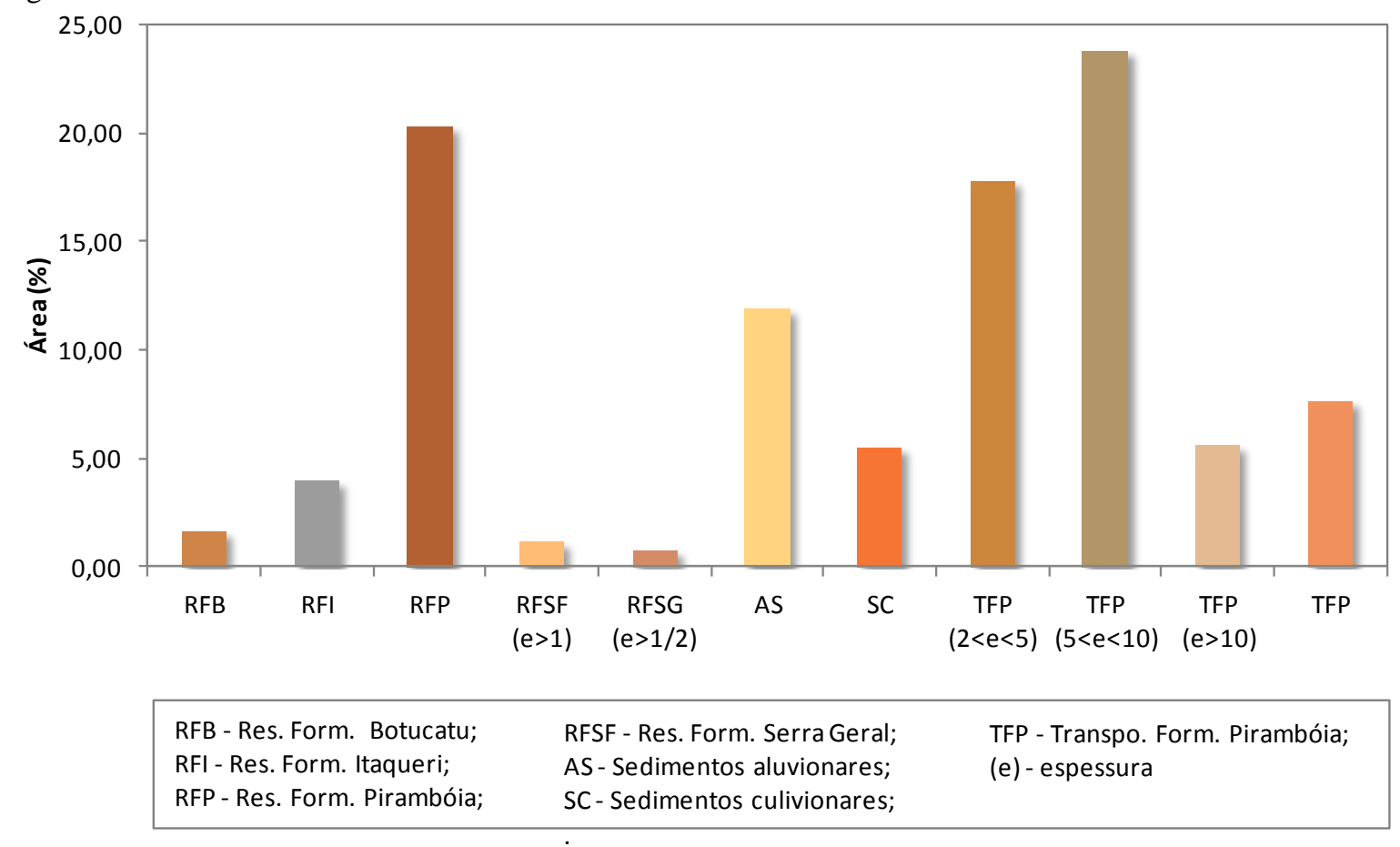

Os materiais Transportados Associados à Formação Pirambóia englobam quase toda a área em estudo, com espessuras superiores a $1 / 2$ metro, são muito arenosos e se caracteriza por ser um material altamente susceptível à erosão, fator que pode ser agravado em função de da inclinação dos terrenos e/ou ausência de cobertura vegetal. Estes materiais são constituídos por estrutura porosa, sem cimentação (GOMES, 2002).

Os materiais Residuais da Formação Pirambóia apresentam diferentes níveis de alteração, classificados como: saprolíticos e saprólitos. O material residual jovem apresenta textura arenosa fina e baixo potencial erosivo, diferente do residual maduro que tende a ser mais erodível e se caracteriza pela textura areno-argilosa (GOMES, 2002). O Mapa de Materiais inconsolidados da Bacia do Córrego do Meio está ilustrado na Figura 47. 
Figura 47 - Mapa de materiais inconsolidados da Bacia do Córrego do Meio.

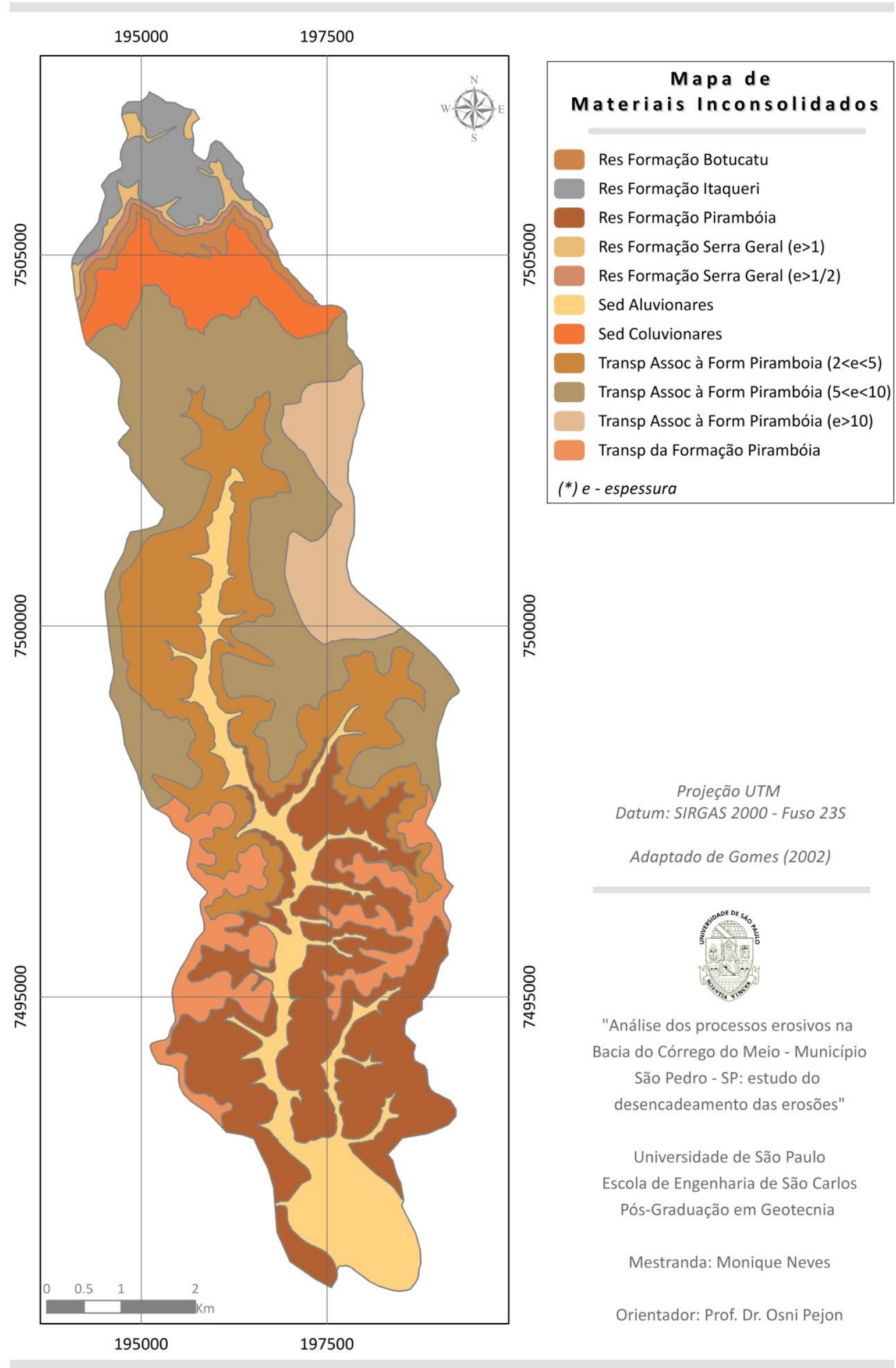




\subsection{Dados de ensaios geotécnicos}

Através das informações de ensaios laboratoriais compilados do trabalho de Gomes (2002) foi possível realizar a caracterização geotécnica da área em estudo. A Tabela 22 apresenta uma síntese com os valores máximo, médio e mínimo dos parâmetros geotécnicos por unidade de material inconsolidado e no Anexo A, encontra-se uma tabela com os resultados dos ensaios para todos os pontos amostrados. Destacam-se algumas características por unidades de materiais:

- Formação Itaqueri: arenosos com porcentagem de areia entre 59 e 77\%; espessura superior a 2m; predominância de argilominerais de baixa atividade; baixo potencial à erosão $(\mathrm{E}<1)$;

- Serra Geral: textura argilo-areno-siltosa; porcentagem de argila entre 12 e $45 \%$, areia entre 30 e $68 \%$, e silte entre 8 e $25 \%$; argilominerais de atividade média; e baixo potencial à erosão $(\mathrm{E}<1)$;

- Transportado associado à formação Serra Geral: textura argilo-areno-siltosa; argila entre 36 e $56 \%$, areia entre 20 e $56 \%$ e silte entre 7 e $26 \%$; argilominerais de baixa atividade e baixo potencial à erosão;

- Residual da Formação Botucatu: resultam na alteração do arenito; porcentagem de areia entre 84 e $87 \%$; argilominerais de baixa atividade;

- Residual da Formação Pirambóia (Jovem): textura arenosa fina; espessura entre 1/2 e $2 \mathrm{~m}$; porcentagem de areia entre 49 e $75 \%$; predominância de argilomineirais de baixa atividade; e baixo potencial aos processos erosivos;

- Residual da Formação Pirambóia (Maduro): textura areno-argilosa; espessura entre $1 / 2$ e $2 \mathrm{~m}$; porcentagem de areia entre 66 e 85\%; argilomineirais de baixa atividade; maior potencial de erodibilidade nas camadas mais evoluídas;

- Transportado associado à Formação Pirambóia: espessura superior a 1/2 metro; materiais arenosos, com textura de areia fina à média, porcentagem de areia entre 79 e 93\%; baixa atividade de argilominerias; altamente erodível; 
- Materiais coluvionares: textura areia grossa; porcentagem de areia entre 81 e $86 \%$, argilominerais de muito baixa atividade;

- Materiais aluvionares: textura areia grossa, porcentagem de areia entre 94 e 96\%, baixa atividade de argilominerais. 
Tabela 22 - Dados referentes aos materiais inconsolidados presentes na Bacia do Córrego do Meio.

\begin{tabular}{|c|c|c|c|c|c|c|c|c|c|c|c|c|c|c|c|}
\hline & & & \multicolumn{3}{|c|}{ GRANULOMETRIA } & \multicolumn{3}{|c|}{ ÍNDICES FÍSICOS } & \multicolumn{4}{|c|}{ ENSAIO DO AZUL DE METILENO } & \multicolumn{3}{|c|}{ ENSAIO DE ERODIBILIDADE } \\
\hline & & & Argila & Silte & Areia & $\rho_{s}$ & $\rho_{d}$ & $e_{0}$ & $V B$ & $A c b$ & CTC & $S E$ & $S$ & $P$ & $E$ \\
\hline & & & \multicolumn{3}{|c|}{$(\%)$} & $\left(\mathrm{g} / \mathrm{cm}^{3}\right)$ & $\left(\mathrm{g} / \mathrm{cm}^{3}\right)$ & & (g/100g solo) & $(\mathrm{g} / 100 \mathrm{~g}$ argila $)$ & $(\mathrm{mEq} / 100 \mathrm{~g}$ solo $)$ & $\left(\mathrm{m}^{2} /\right.$ argila $)$ & \multicolumn{3}{|c|}{$(\%)$} \\
\hline \multirow{3}{*}{ 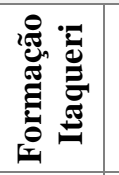 } & \multirow{3}{*}{ Residual } & Mínimo & 12,2 & 7,1 & 59,0 & 2,604 & 0,941 & 0,67 & 0,290 & 1,171 & 0,900 & 7,374 & 0,55 & 0,75 & 2,54 \\
\hline & & Médio & 19,7 & 10,4 & 68,7 & 2,641 & 1,335 & 0,86 & 0,430 & 1,480 & 1,086 & 18,210 & 1,09 & 4,58 & 24,47 \\
\hline & & Máxima & 30,0 & 19,6 & 77,5 & 2,672 & 1,592 & 0,99 & 0,896 & 2,009 & 1,802 & 27,134 & 1,80 & 11,80 & 96,00 \\
\hline \multirow{6}{*}{ 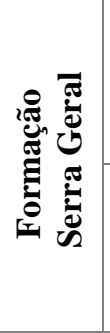 } & \multirow{3}{*}{ Transportado } & Mínimo & 36,5 & 7,5 & 20,6 & 2,791 & 0,920 & 0,89 & 0,7900 & 1,2145 & 2,8653 & 43,1825 & 0,12 & 1,02 & 4,71 \\
\hline & & Médio & 46,6 & 17,5 & 35,9 & 2,875 & 1,145 & 0,31 & 1,1176 & 2,2825 & 3,9152 & 74,4797 & 0,20 & 1,06 & 3,29 \\
\hline & & Máxima & 56,0 & 26,5 & 56,0 & 3,050 & 1,325 & 1,89 & 1,7125 & 3,9417 & 5,8290 & 109,1764 & 0,68 & 3,22 & 8,45 \\
\hline & \multirow{3}{*}{ Residual } & Mínimo & 12,2 & 8,7 & 30,0 & 2,660 & 1,096 & 0,67 & 0,8962 & 3,0124 & 2,8016 & 21,9279 & 1,45 & 0,08 & 4,23 \\
\hline & & Médio & 31,9 & 17,6 & 50,6 & 2,801 & 1,327 & 1,00 & 2,1457 & 7,3628 & 7,1056 & 80,3114 & 2,39 & 6,89 & 834,62 \\
\hline & & Máxima & 45,0 & 25,0 & 68,2 & 2,900 & 1,592 & 1,18 & 4,0200 & 12,6500 & 11,3164 & 137,8941 & 3,33 & 13,70 & 1665,00 \\
\hline \multirow{3}{*}{ 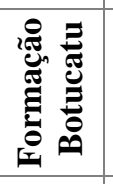 } & \multirow{3}{*}{ Residual } & Mínimo & 7,0 & 3,9 & 84,3 & 2,613 & 1,497 & 0,56 & 0,1987 & 2,6120 & 0,6587 & 4,0549 & - & - & - \\
\hline & & Médio & 8,6 & 5,0 & 86,3 & 2,621 & 1,553 & 0,67 & 0,3594 & 2,8429 & 1,3090 & 5,0081 & 0,35 & 5,98 & 2,54 \\
\hline & & Máxima & 10,5 & 6,0 & 87,7 & 2,629 & 1,692 & 0,79 & 0,5035 & 2,9917 & 2,2189 & 5,9821 & - & - & - \\
\hline \multirow{9}{*}{ 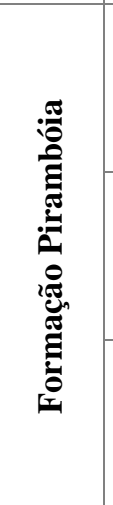 } & \multirow{3}{*}{ Transportado } & Mínimo & 5,0 & 1,4 & 79,9 & 2,608 & 1,503 & 0,42 & 0,056 & 1,407 & 0,176 & 1,377 & 0,22 & 35,38 & 0,22 \\
\hline & & Médio & 10,3 & 4,1 & 85,7 & 2,645 & 1,547 & 0,66 & 0,431 & 3,916 & 1,293 & 10,426 & 0,68 & 53,51 & 0,62 \\
\hline & & Máxima & 16,2 & 11,1 & 93,6 & 2,699 & 1,751 & 0,75 & 0,970 & 6,994 & 2,995 & 23,965 & 1,26 & 77,37 & 1,66 \\
\hline & \multirow{3}{*}{ Saprolítico } & Mínimo & 4,3 & 3,6 & 66,9 & 2,602 & 1,470 & 0,57 & 1,785 & 7,385 & 5,126 & 43,664 & 0,24 & 2,18 & 1,26 \\
\hline & & Médio & 17,3 & 10,4 & 73,2 & 2,643 & 1,648 & 0,60 & 3,319 & 26,965 & 9,510 & 69,323 & 0,47 & 5,55 & 4,87 \\
\hline & & Máxima & 27,2 & 21,7 & 85,0 & 2,689 & 1,750 & 0,67 & 5,569 & 84,399 & 14,282 & 111,783 & 0,67 & 10,52 & 12,29 \\
\hline & \multirow{3}{*}{ Saprólito } & Mínimo & 16,8 & 4,9 & 49,0 & 2,603 & 1,570 & 0,45 & 1,681 & 3,475 & 2,159 & 16,664 & 0,39 & 0,08 & 30,89 \\
\hline & & Médio & 20,9 & 11,9 & 67,2 & 2,641 & 1,603 & 0,51 & 2,858 & 15,356 & 6,926 & 64,117 & 0,50 & 0,25 & 156,63 \\
\hline & & Máxima & 25,3 & 26,3 & 78,3 & 2,673 & 1,670 & 0,61 & 4,852 & 34,156 & 13,104 & 118,720 & 0,61 & 0,79 & 270,18 \\
\hline
\end{tabular}




\subsection{Processamento de Dados em SIG}

\subsubsection{MDE (Modelo Digital de Elevação)}

O MDE constitui um dos planos de informação de maior importância, por ser um arquivo base para obtenção dos parâmetros declividade e área de contribuição. Desta forma, buscou-se avaliar não só a consistência hidrológica do modelo obtido, como também a sua resolução espacial, com a finalidade de representar os processos analisados de maneira fidedigna.

Foram gerados três modelos digitais de elevação, com pixels de 2, 10 e 30 metros, como pode ser observado na Figura 48. Os valores máximos e mínimos de elevação obtidos foram aproximadamente 930 e 447 metros, respectivamente. Em função do tamanho do pixel esses valores apresentaram pequenas variações, que não se refletem tanto no MDE, porém podem ser significativos para a elaboração de outros mapas, como o de declividade.

Nota-se, portanto, que o tamanho do pixel interfere na obtenção de outros planos de informação, e consequentemente no seu processamento, uma vez que modelos mais detalhados demandam um melhor desempenho computacional, e maior tempo para processar os dados, o que se deve principalmente ao número de linhas e colunas de cada um dos modelos, conforme apresentado na Tabela 23

Tabela 23 - Número de colunas e linhas dos modelos digitais de elevação.

\begin{tabular}{c|c}
\hline Tamanho do pixel & Colunas, linhas \\
\hline $2 m$ & 2579,8043 \\
\hline $10 m$ & 516,1609 \\
\hline $30 m$ & 172,536 \\
\hline
\end{tabular}


Figura 48 - Modelos Digitais de Elevação (MDE).

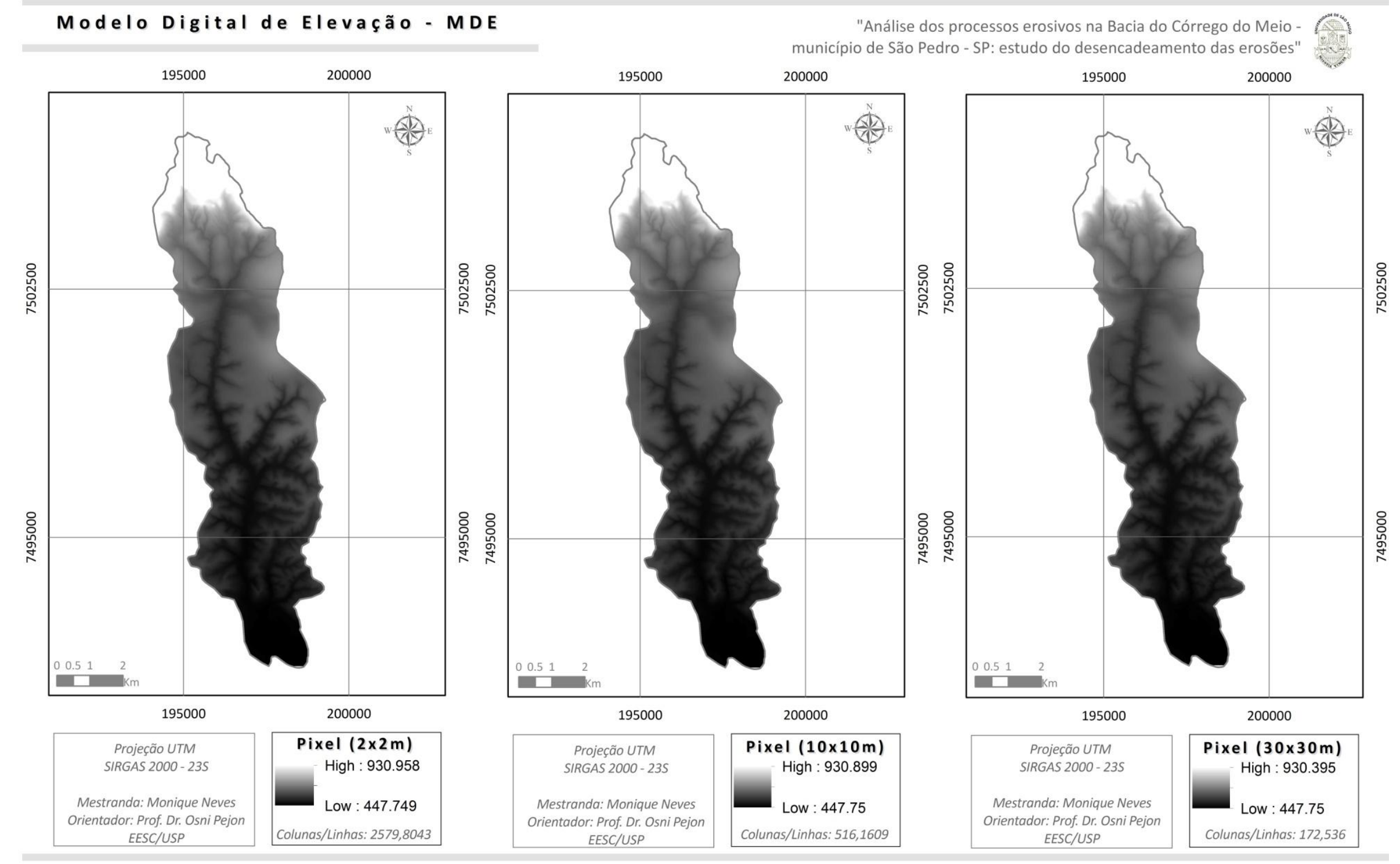




\subsubsection{Carta de Declividades}

A Carta de Declividades consiste na representação cartográfica da inclinação do terreno em graus ou valores percentuais. A declividade é determinada pela diferença de elevação entre dois pontos (dA) e a distância horizontal (dH) entre eles (Figura 49).

Figura 49 - Representação da declividade.
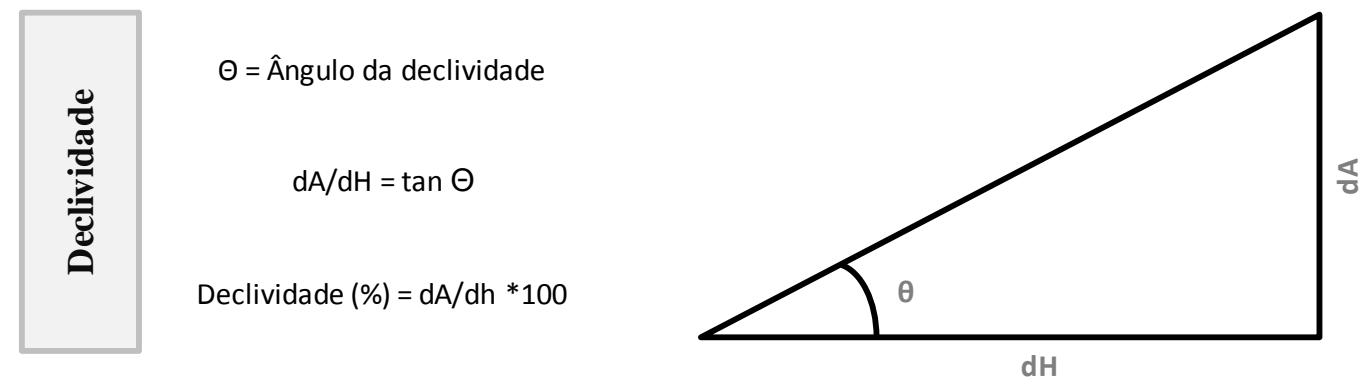

A classe de declividade predominante na Bacia do Córrego do Meio corresponde ao intervalo de 5 a 15\%, que de acordo com IG (1993), se caracteriza por terrenos inclinados ou muito inclinados, com relevo ondulado e escoamento superficial rápido, que ocasionam problemas de erosão, que podem ainda ser agravados devido às características geológicas e pedológicas da área, principalmente os solos arenosos. A Figura 50 apresenta a distribuição das classes de declividade em valores percentuais, e as cartas de declividades podem ser observadas na Figura 51.

Figura 50 - Percentual de ocorrência das classes de declividades.

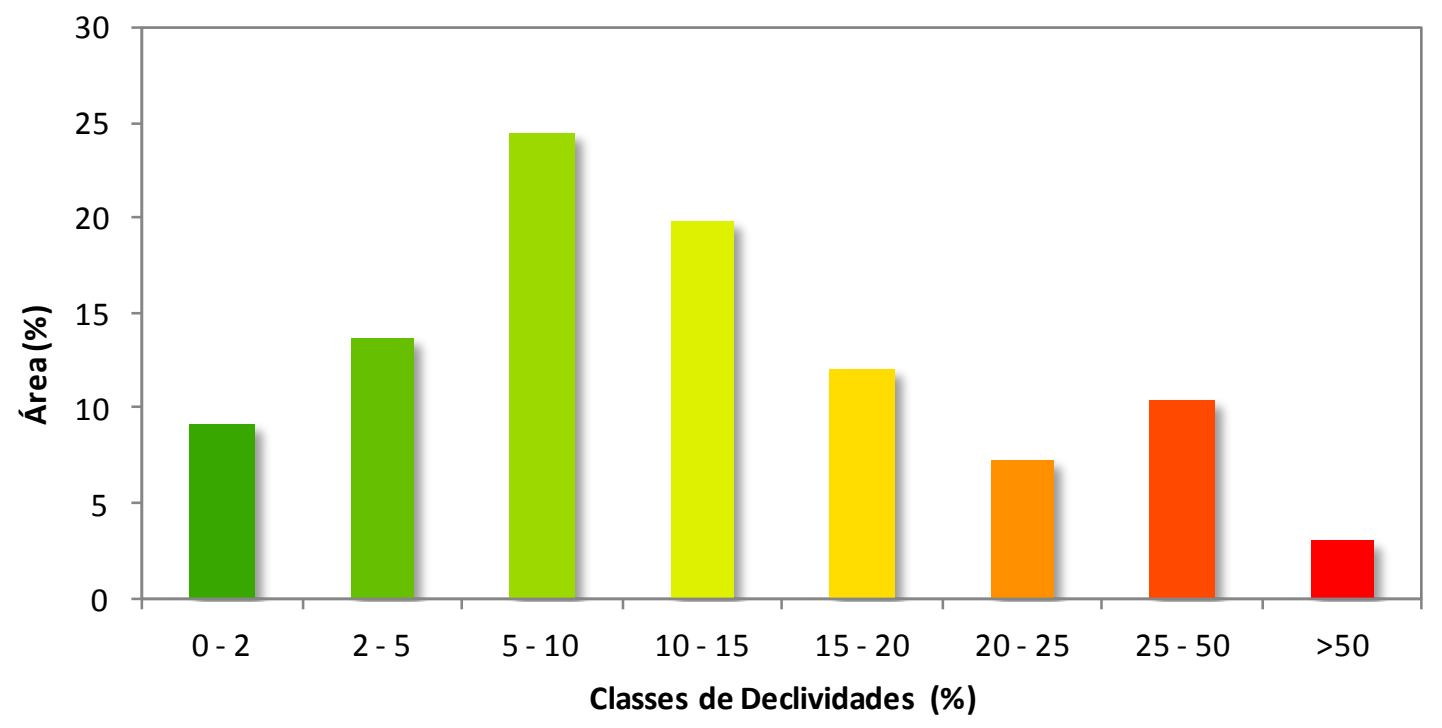


Figura 51 - Cartas de Declividades.

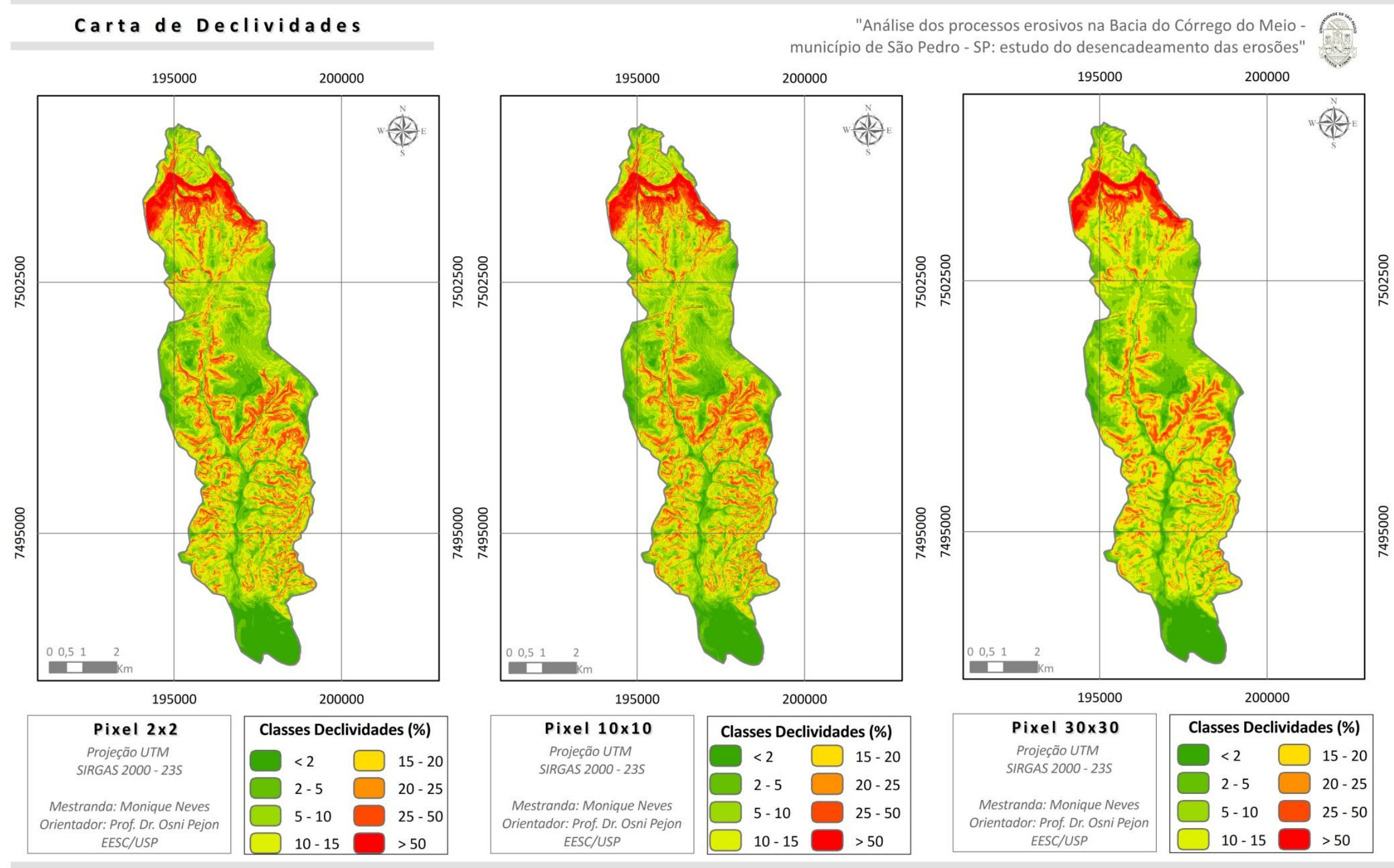


Observa-se que, em função do tamanho dos pixels, alguns valores deixaram de ser representados, principalmente para a carta de declividades com pixel de $30 \mathrm{~m}$, que apresentou maior variabilidade espacial. Para a carta com pixel de $2 \mathrm{~m}$ o valor máximo obtido foi de $165,51 \%$, que corresponde a $59^{\circ}$, diferente da carta com resolução de $30 \mathrm{~m}$, que apresentou valor máximo de $130 \%$, sendo $52^{\circ}$. A Figura 52 apresenta uma parte da área em estudo, de maneira detalhada, evidenciando a interferência da resolução espacial, na distribuição das classes de declividades.

Figura 52 - Variabilidade espacial das classes de declividade.

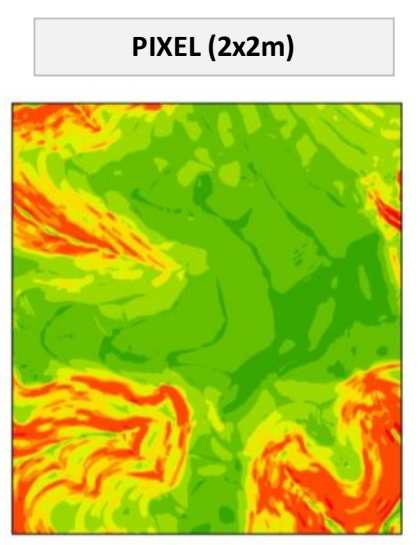

DECLIVIDADE MÉDIA (\%): 14,98

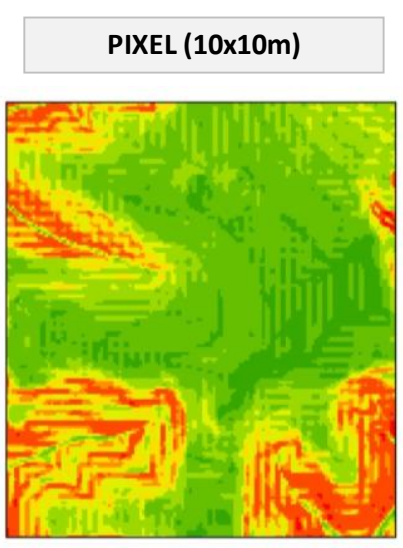

DECLIVIDADE MÉDIA (\%): 13,98

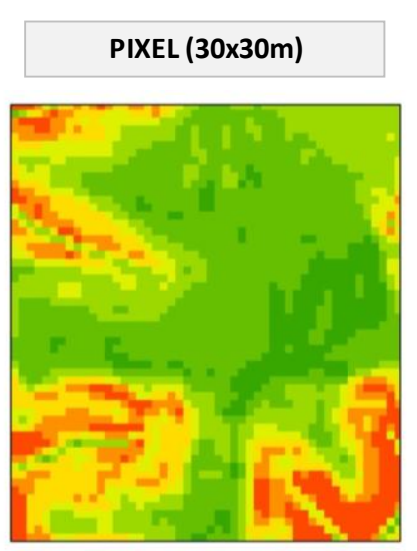

DECLIVIDADE MÉDIA (\%): 13,01

\subsubsection{Aspectos Hidrológicos}

A análise dos aspectos hidrológicos levou em conta o tamanho do pixel (2, 10 e $30 \mathrm{~m})$ e o algoritmo de interpolação. Os mapas de direção de fluxo foram utilizados como parâmetros de entrada para obtenção do fluxo acumulado, que determina as áreas de acúmulo de água em uma determinada região considerando a quantidade de pixels que drenam da jusante para o exutório da bacia. Os valores são expressos em $\mathrm{m}^{2}$, pois são calculados pixel a pixel e leva-se em consideração o sistema de unidade dos parâmetros de entrada.

Verificou-se que o tamanho do pixel interfere significativamente nos valores máximos de fluxo acumulado, independente do algoritmo utilizado. Os resultados indicam que quanto menor a resolução, menor será este valor, ou seja, mapas com pixels maiores (30 m) deixam de representar zonas de acúmulo de água menores, que por sua vez, correspondem aos canais de primeira ordem da rede hidrográfica. É importante destacar, que a mesma tendência ocorre para os mapas elaborados para áreas menores, por exemplo, sub-bacias. 
A Figura 53 apresenta um gráfico com os valores máximos de fluxo acumulado calculados para a Bacia do Córrego do Meio, verifica-se que a distribuição dos dados é semelhante para ambos os algoritmos, no entanto as variações entre os valores máximos tende a ser maior para o D8. Observa-se também que para dados com pixels menores $(2 \mathrm{~m})$ a diferença entre os valores máximos em função do algoritmo não é tão expressiva quanto para os dados com pixels (30m).

Figura 53 - Valores máximos de fluxo acumulado para a Bacia do Córrego do Meio em função do tamanho do pixel.

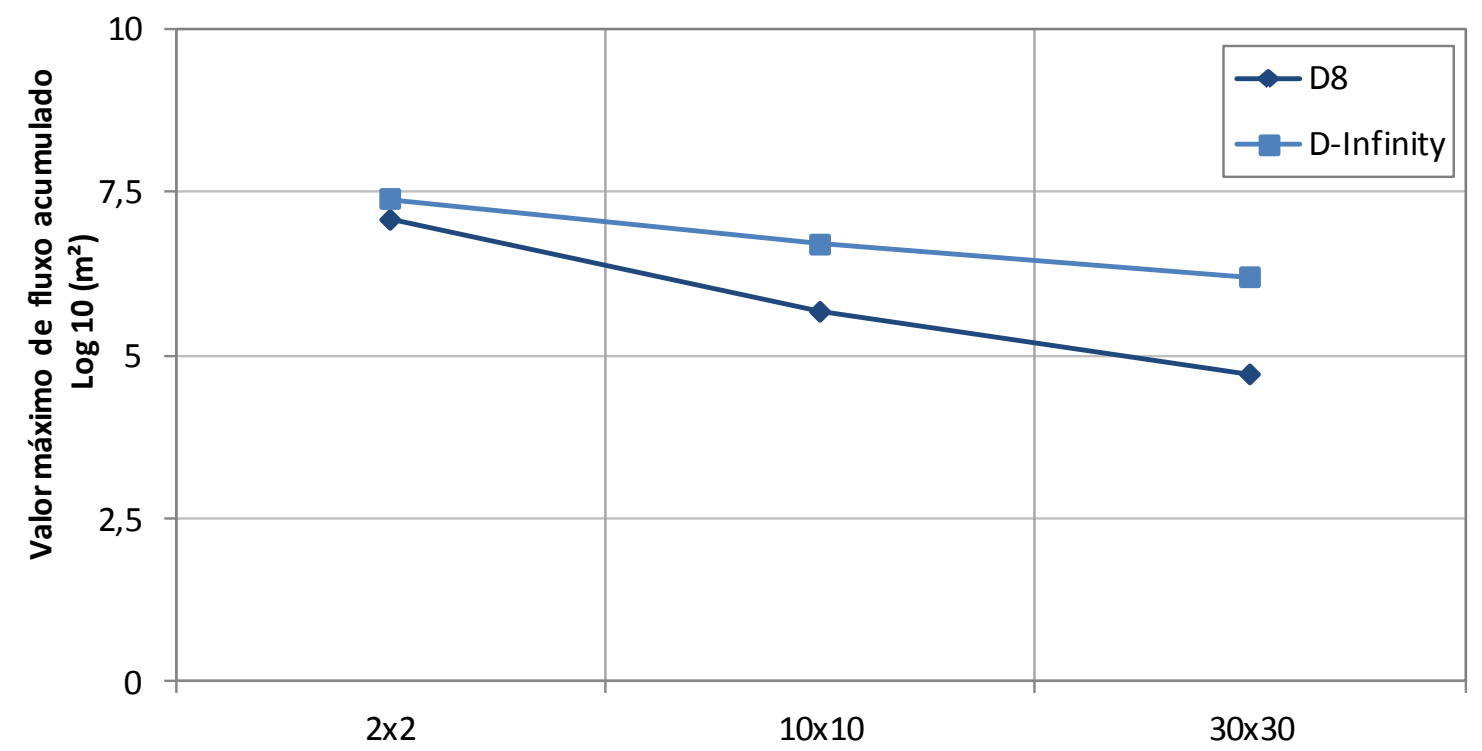

Os Mapas de Fluxo Acumulado obtido pelo algoritmo D8 e D-Infinity podem ser obervados na Figura 54 e Figura 55, respectivamente. Os valores de fluxo acumulado estão em escala logarítmica, devido à variabilidade existente em relação à distribuição dos dados, e foram divididos em 6 classes de área de contribuição para melhor visualização dos dados.

Observa-se que tanto para o D8 como o D-Infinity, as áreas com as maiores classes de área de contribuição estão localizadas nas porções mais baixas do relevo, nos vales fechados, com alta densidade de canais, enquanto que as classes mais baixas ocorrem nas regiões mais planas, no topo das encostas.

Como descrito por Ramos et al. (2003), a representação do fluxo acumulado com maior precisão está diretamente relacionada com a elaboração de modelos de elevação hidrologicamente consistentes, que indiquem com maior exatidão as direções de fluxo. 
Figura 54 - Mapa de Fluxo Acumulado (D8).

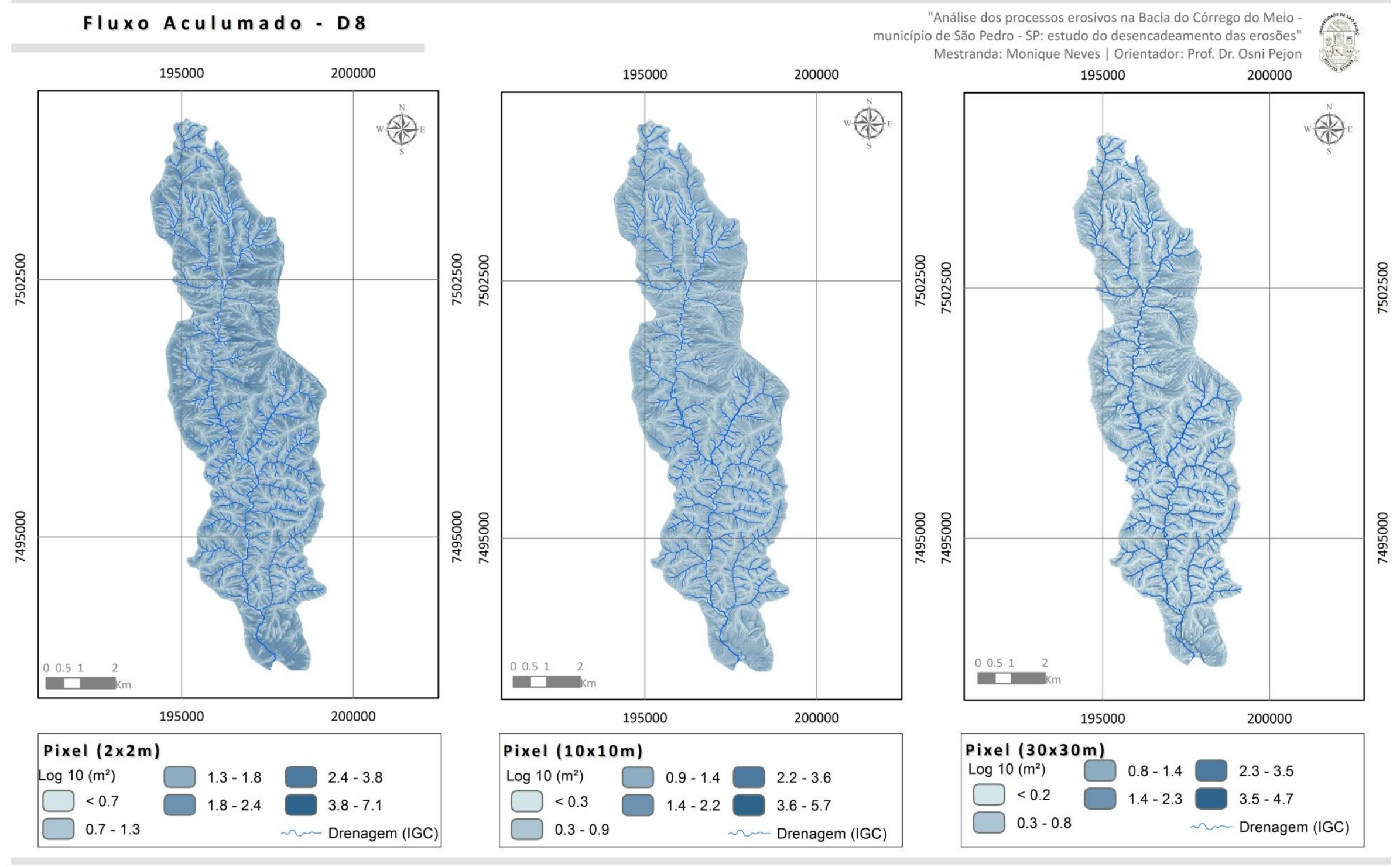


Figura 55 - Mapa de Fluxo Acumulado (D-Infinity).

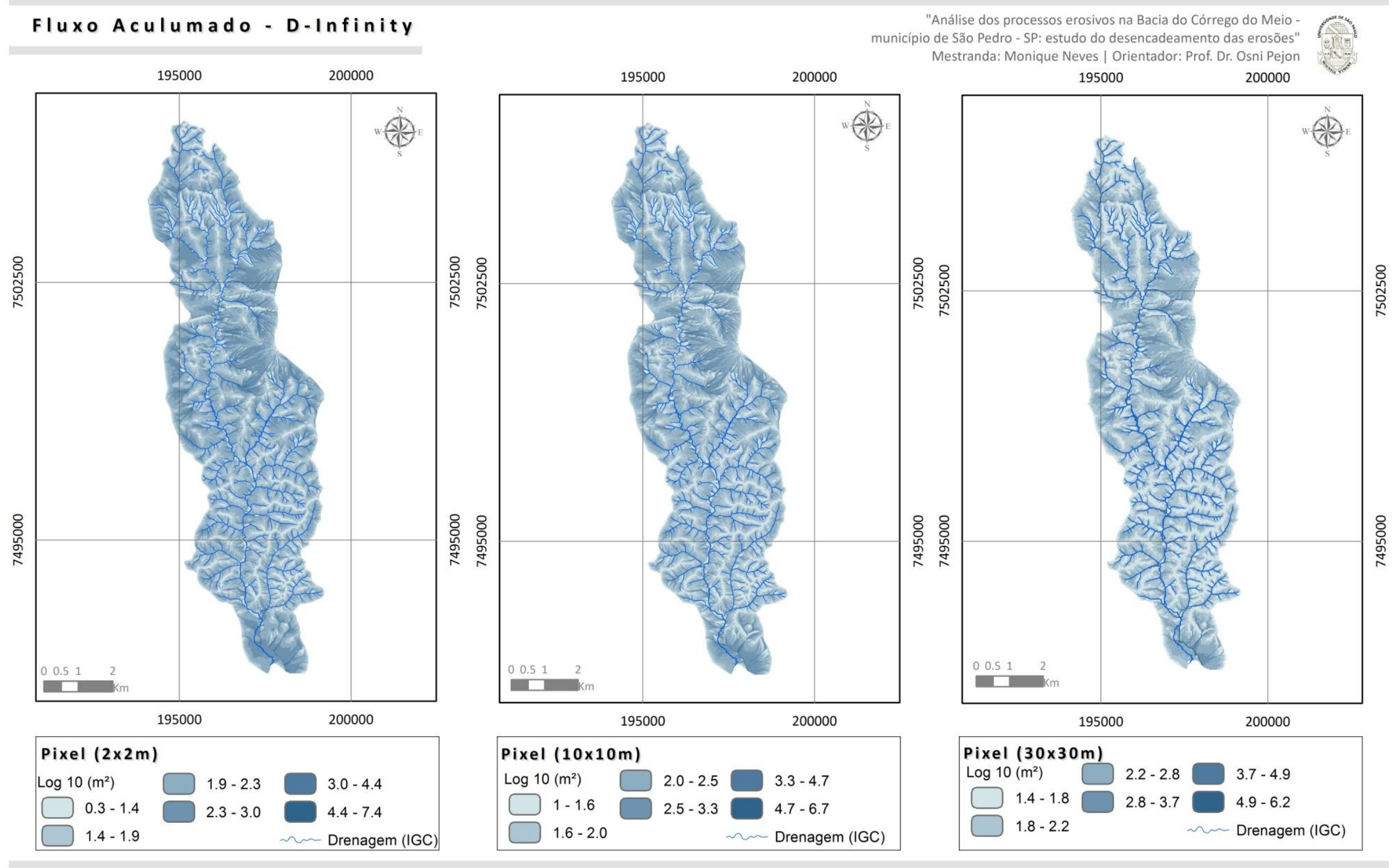


Com a finalidade de verificar a interferência dos algoritmos na análise dos processos erosivos, elaboraram-se os mapas da Figura 56, que mostram uma região da bacia com concentração de feições erosivas (sulcos e ravinas). O mapa obtido pelo método D-Infinity apresenta melhores resultados, uma vez que define regiões de fluxo acumulado mais distribuídas e não concentradas como o D8, o que se deve a teoria envolvida na determinação da direção de fluxo. Pode-se constatar também que estas áreas estão relacionadas com as feições existentes, mostrando que as zonas de acumulação de água delimitadas, podem ocasionar o surgimento de processos erosivos.

Figura 56 - Mapas de fluxo acumulado e feições erosivas.

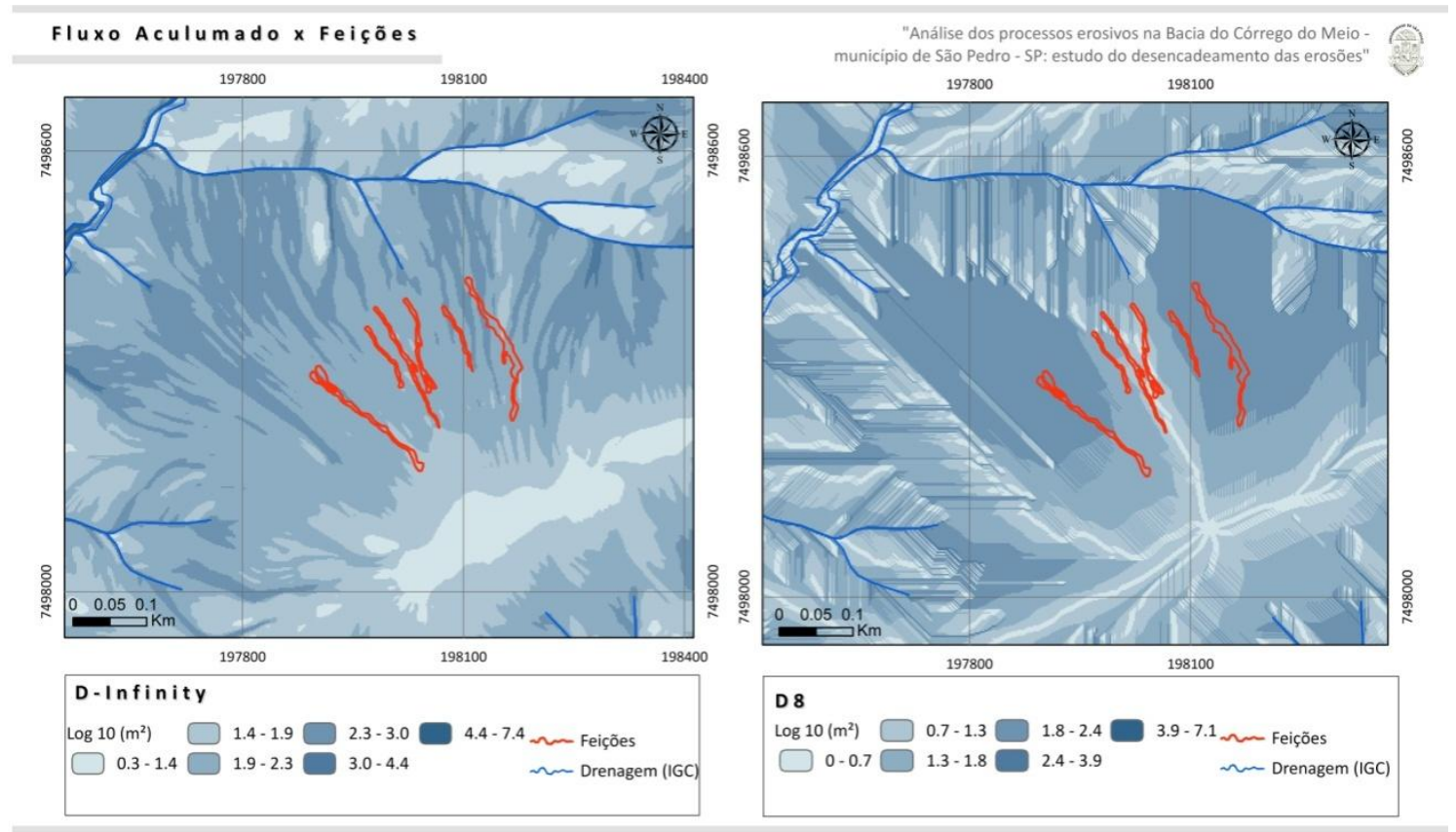

A partir da análise hidrológica podem-se comparar os algoritmos para obtenção dos mapas de área de contribuição. Como constatado por autores como Ramos et al. (2003), verifica-se que o D-Inifnity determina as direções de fluxo com maior exatidão, permitindo uma análise mais consistente dos processos erosivos em conformidade com as características do meio físico. No entanto, para confirmar à interferência destes aspectos no limiar de desencadeamento das erosões, realizaram-se outras análises, descritas no próximo item.

\section{4 Índice SxA: Sub-bacia dos Alpes e Retiro}

A análise das erosões localizadas na Sub-Bacia dos Córregos dos Alpes e Retiro foi realizada com dois propósitos: avaliar a interferência da resolução espacial na determinação do índice $\mathrm{S} x \mathrm{~A}$; e comparar os índices obtidos por diferentes algoritmos de mapeamento de fluxo acumulado. 


\subsubsection{Interferência da resolução espacial na elaboração dos índices}

Com a finalidade de comparar o efeito da resolução espacial dos modelos digitais de elevação na obtenção dos mapas de fluxo acumulado e carta de declividade, e consequentemente na relação $\mathrm{S} x \mathrm{~A}$, realizou-se uma análise considerando 12 feições erosivas localizadas na Sub-bacia dos Córregos dos Alpes e Retiro.

Determinaram-se as áreas de contribuição (A) e declividade média (S) para cada uma das feições, utilizando os arquivos matriciais obtidos nas etapas anteriores. A igura 57 ilustra as áreas de contribuição para algumas destas feições obtidas com o algoritmo D-Infinity. Como descrito no item (5.3.1) a resolução espacial interfere significativamente na representação dos dados, no caso das áreas de contribuição quanto maior o pixel, maior o valor destas áreas.

Figura 57 - Áreas de contribuição determinadas pelo D-Infinity com pixels de diferentes tamanhos.

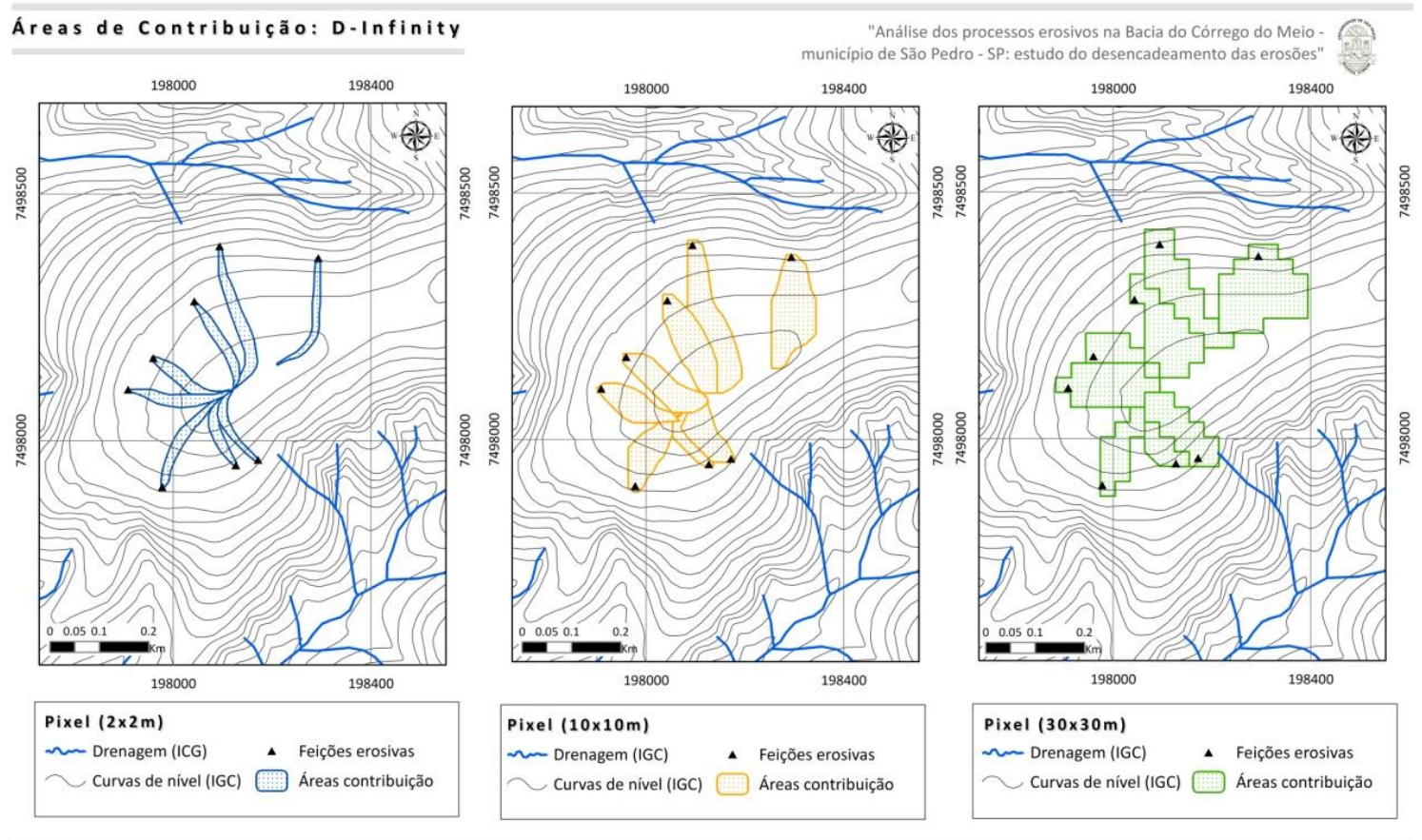

A Figura 58 apresenta o gráfico com a relação $\mathrm{S} x \mathrm{~A}$, para os dados com diferentes resoluções. Constatou-se que ao propor um limiar para desencadeamento dos processos erosivos a partir dos dados provenientes do $\operatorname{MDE}(2 \times 2 \mathrm{~m})$, é necessária uma área de contribuição menor, o que tende a aumentar de acordo com o tamanho do pixel. Especificamente em relação aos dados obtidos pelo MDE (30x30m), as áreas são muito maiores, e como foram geradas por processamento automático podem não estar coerentes com as características reais da área. 
Quanto à declividade média, verifica-se que os dados apresentam uma variação menos intensa para os valores médios, o que se deve a distribuição espacial dos dados na Carta de Declividades, todavia estas variações devem ser consideradas, pois a ocorrência dos processos erosivos na área em estudo apresenta forte relação com a inclinação do terreno.

Além disso, analisando o $\mathrm{R}^{2}$, obtido pelo ajuste da linha de potência, constata-se que, os parâmetros obtidos por meio dos modelos com resolução de 2x2m apresentam melhor ajuste, evidenciando que, para a representação dos limiares de desencadeamento dos processos erosivos, torna-se fundamental a utilização de dados matriciais, mais precisos, com resoluções maiores.

Figura 58 - Gráfico SxA para os dados processados com pixels de diferentes tamanhos.

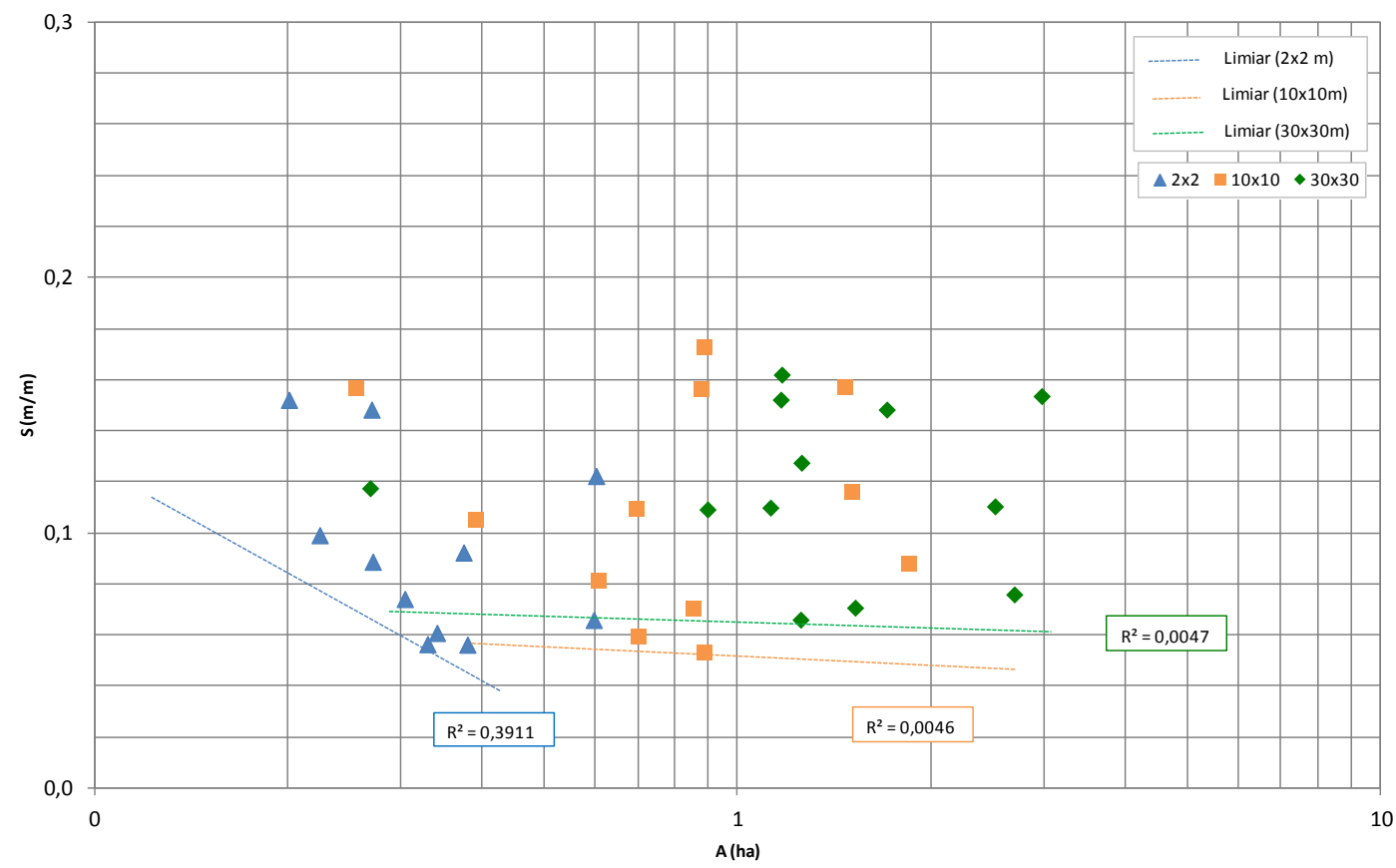

Neste contexto, concluiu-se que para a Bacia do Córrego do Meio o MDE 2x2m é o mais propicio para elaboração dos mapas de área de contribuição e declividade. Para avaliação dos limiares de desencadeamento dos processos erosivos, torna-se fundamental a utilização de dados matriciais, mais preciso, com resoluções maiores, conforme citado por Zhang e Montgomery (1994), uma vez que a representação espacial dos fenômenos deve estar em consonância com as características geomorfológicas da área.

\subsubsection{Aplicação do D-Infinity para os índices propostos por Araújo (2011)}

Para realização desta etapa considerou-se os dois índices propostos por Araújo (2011): canais rasos $(<1 \mathrm{~m})$ e canais profundos $(>1 \mathrm{~m})$. Foram utilizados os mesmos pontos de feições 
erosivas, no entanto para processamento automático das áreas de contribuição o autor utilizou o algoritmo D8, e no presente trabalho foi utilizado o D-Infinity.

\subsubsection{Canais Rasos}

Os canais rasos compreendem 11 pontos de erosão com profundidade menor que 1 metro, localizados em encostas onde predominam os materiais transportados associados à Formação Pirambóia. Nestas áreas ocorre a unidade de landforms C5, que se caracteriza por vales fechados com encostas retilíneas e convexas, que por sua vez como descrito por Vilar (1989), estão associadas às maiores taxas de perda de solo. A Figura 59 ilustra algumas destas feições.

Figura 59 - Canais rasos visualizados nas ortofotos.

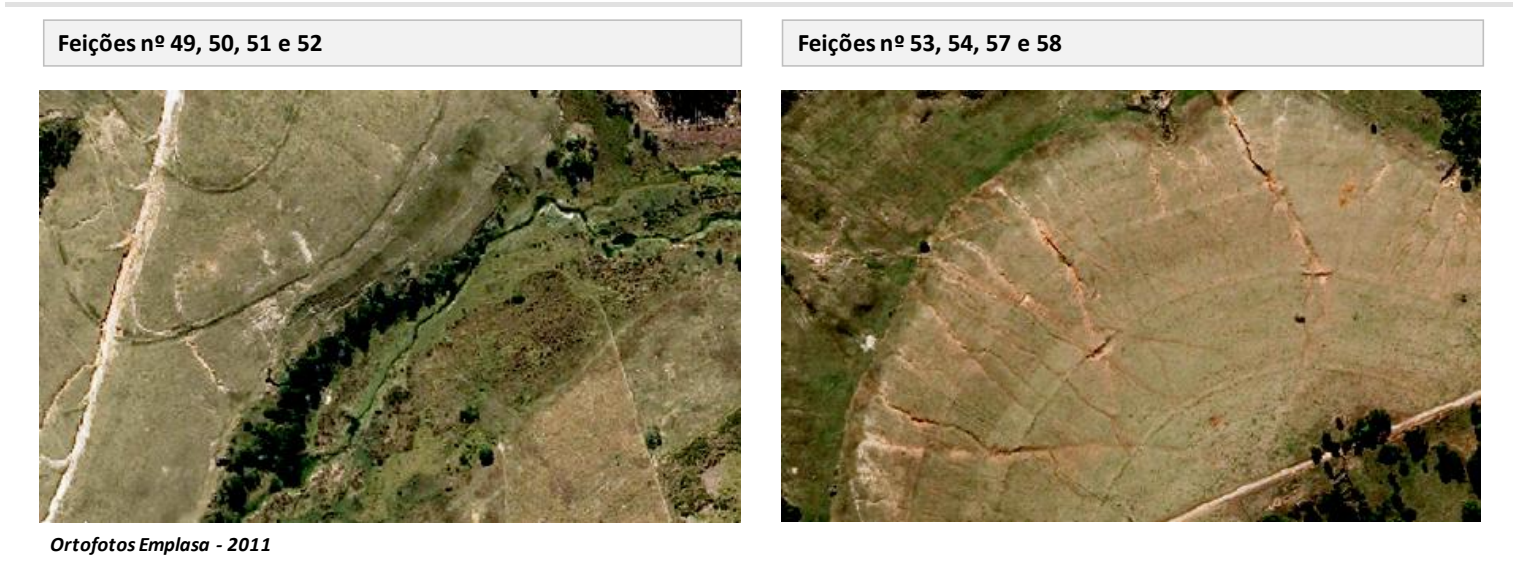

Ao analisar a situação atual destes canais por meio das imagens de satélite de 2016, verifica-se que, algumas destas feições não estão mais presentes na Sub-bacia dos Córregos dos Alpes e Retiro, e podem ter sido recuperadas por práticas agrícolas mecânicas. As feições que ainda estão presentes na área estão associadas ao uso agrícola intenso, principalmente a áreas de cultivo de cana-de-açúcar.

A Figura 60 apresenta o gráfico $\mathrm{S} x \mathrm{~A}$ para os canais rasos. O ajuste do limiar crítico indica que o desencadeamento destas feições está associado a declividades baixas e áreas de contribuição menores. Com base na equação de ajuste, apresentada na Figura 60 para uma área de contribuição de 1 ha $\left(10.000 \mathrm{~m}^{2}\right)$ a declividade crítica que levaria ao desencadeamento da erosão seria de $5,9 \%(0,0509 \mathrm{~m} / \mathrm{m})$.

Ao definir a linha de tendência com função de potência, que serviu como base para ajuste do limiar crítico, obteve-se o $\mathrm{R}^{2}$ de 0,1874 . O valor baixo deste coeficiente evidencia que existem outras variáveis associadas, como profundidade dos canais, características 
geormorfológicas e de uso do solo que podem interferir no processo de desencadeamento das erosões.

Figura 60 - Gráfico SxA - Canais Rasos.

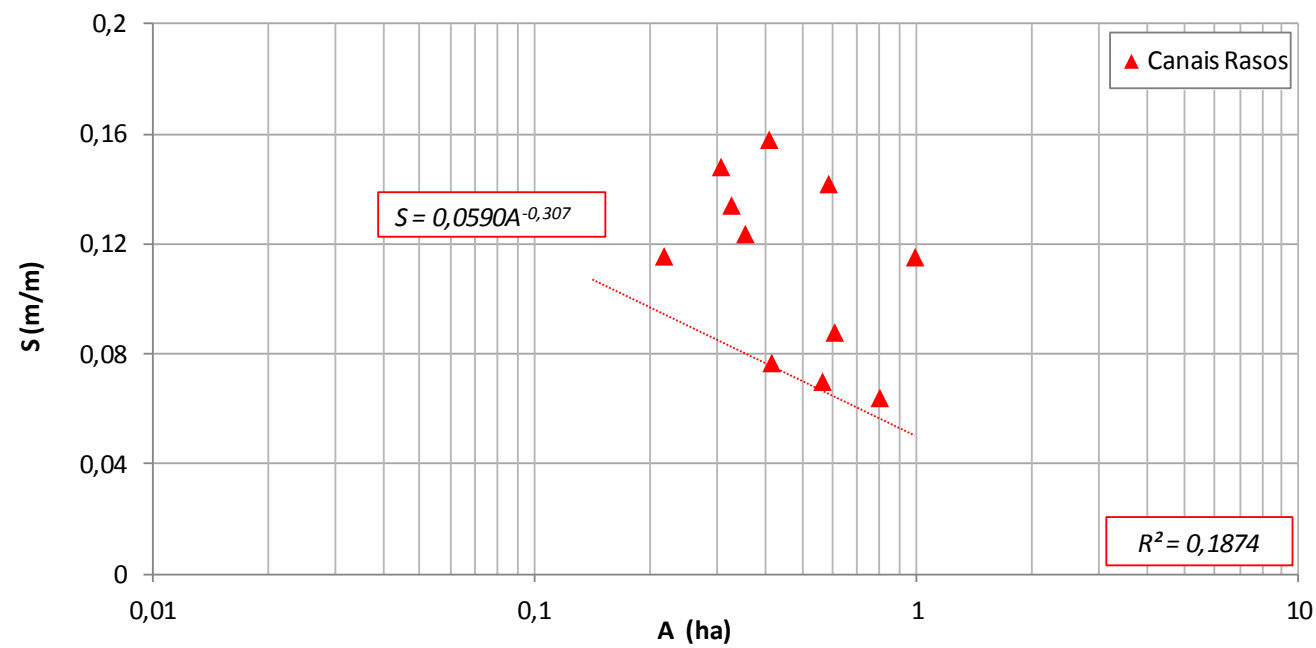

\subsubsection{Canais Profundos}

$\mathrm{Na}$ análise dos canais profundos foram considerados 18 pontos de feições erosivas, sendo ravinas e voçorocas, localizadas em encostas ou drenagem, com mais de 1 metro de profundidade, semelhantes àquelas ilustradas na Figura 61. Estes canais ocorrem em áreas com predominância de materiais transportados da Formação Pirambóia, e nas unidades de landforms C5, que se caracterizam por vales fechados com alta densidade de canais de drenagem, e presença de ravinas.

Figura 61 - Canais profundos visualizados nas ortofotos.
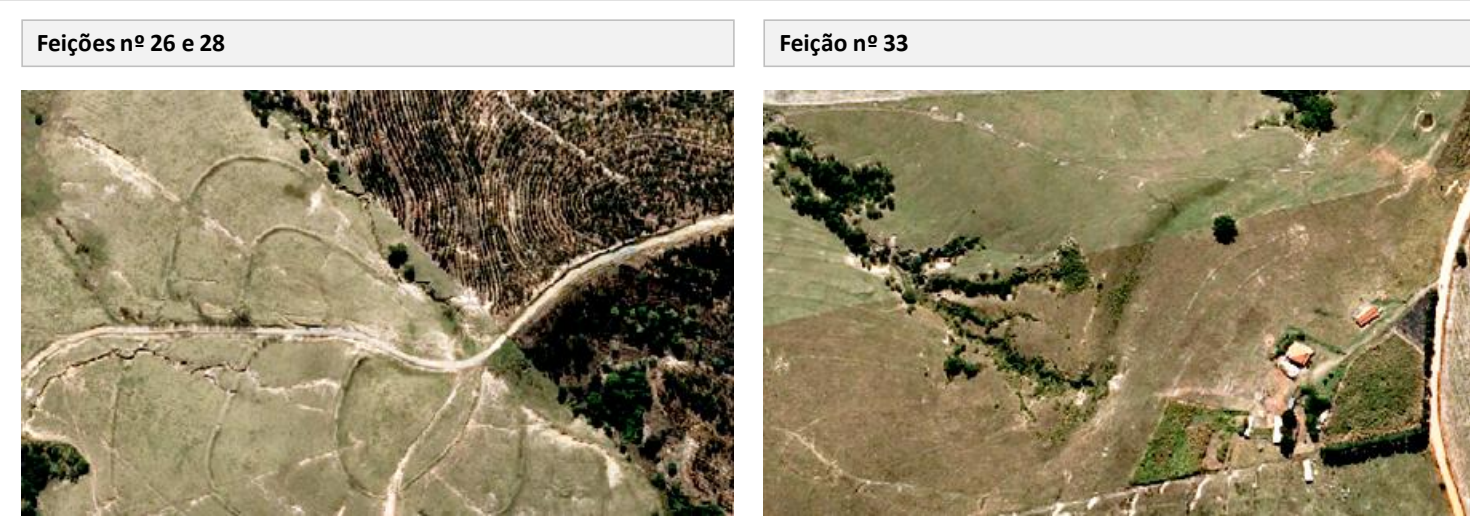

Ortofotos Emplasa - 2011

Analisando as imagens de satélite atuais verifica-se que, a maioria destas feições ainda estão presentes na área, e estão associadas às áreas de pastagem e área urbana, onde ocorrem os problemas mais críticos de erosão. Especificamente nas áreas de chacreamento é possível 
observar que devido à ausência de obras de macrodrenagem nas ruas não pavimentadas o escoamento superficial é direcionado para as erosões, acelerando a ocorrência destes processos.

A Figura 62 ilustra o gráfico SxA para os canais profundos, onde observa-se que o limiar crítico está condicionado a declividade e áreas de contribuição um pouco maiores que o limiar dos canais rasos, o que se deve a maior profundidade destas feições. Aplicando o índice obtido para uma área de contribuição de 1 ha $\left(10.000 \mathrm{~m}^{2}\right)$ a declividade crítica que levaria ao desencadeamento das erosões seria 7,1\% $(0,071 \mathrm{~m} / \mathrm{m})$.

Desta mesma forma que para os canais rasos, percebe-se também um $\mathrm{R}^{2}$ baixo, devido provavelmente a diferentes usos do solo e posicionamento das feições no relevo, visto que algumas estão localizadas em encostas e outras em drenagem.

Figura 62 - Gráfico SxA - Canais profundos.

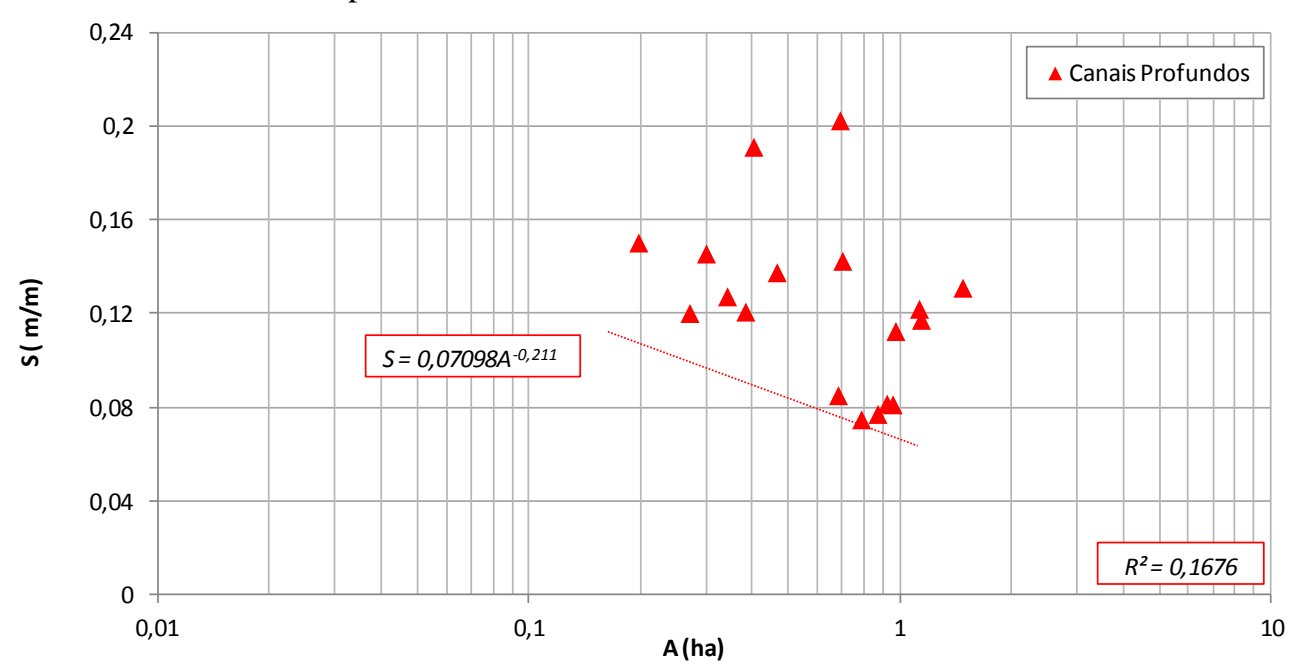

5.4.2.3 Comparação dos índices em função do algoritmo de fluxo acumulado

A análise comparativa entre os índices $\mathrm{S} x \mathrm{~A}$ foi realizada considerando os dados obtidos por Araújo (2011) e os dados do presente trabalho. Como descrito no item (4.2.4) os pontos de feições erosivas são os mesmos e foram analisados da mesma forma, diferindo apenas com relação aos algoritmos usados para gerar o fluxo acumulado. Destaca-se também, que foi considerada a mesma resolução espacial, de $2 \times 2 \mathrm{~m}$, para os parâmetros de entrada.

A Tabela 24 sintetiza os índices para a Sub-bacia do Córrego dos Alpes e Retiro, e também os valores de declividade crítica calculados para uma área de contribuição de 1 ha $\left(10.000 \mathrm{~m}^{2}\right)$. 
Tabela 24 - Índices SxA para a Sub-bacia dos Córregos dos Alpes e Retiro.

\begin{tabular}{c|c|c|c}
\hline Algoritmo & Característica & Índice & Declividade crítica \\
\hline \multirow{2}{*}{$D 8$} & Canais rasos & $\mathrm{S}=0,0128 \mathrm{~A}^{-0,443}$ & $1,28 \%$ \\
\cline { 2 - 4 } & Canais profundos & $\mathrm{S}=0,0219 \mathrm{~A}^{-0,376}$ & $2,19 \%$ \\
\hline \multirow{2}{*}{ D-Infinity } & Canais rasos & $\mathrm{S}=0,0590 \mathrm{~A}^{-0,307}$ & $5,90 \%$ \\
\cline { 2 - 4 } & Canais profundos & $\mathrm{S}=0,0709 \mathrm{~A}^{-0,211}$ & $7,10 \%$ \\
\hline
\end{tabular}

Os valores de declividade crítica obtidos para os índices dos canais rasos e profundos apresentaram diferenças significativas. Considerando que as áreas de contribuição foram processadas de maneira automática, para ambos os algoritmos, fica evidente que a escolha do método se reflete na obtenção dos limiares de desencadeamento das erosões.

Para compreender estas diferenças, elaborou-se para as feições 26 e 33 as áreas de contribuição automaticamente utilizando o D8 e o D-Infinity. As áreas delimitadas foram sobrepostas nas ortofotos, favorecendo a comparação visual dos resultados dos algoritmos (Figura 63).

Figura 63 - Áreas de contribuição processadas automaticamente com os algoritmos D8 e D-Infinity.

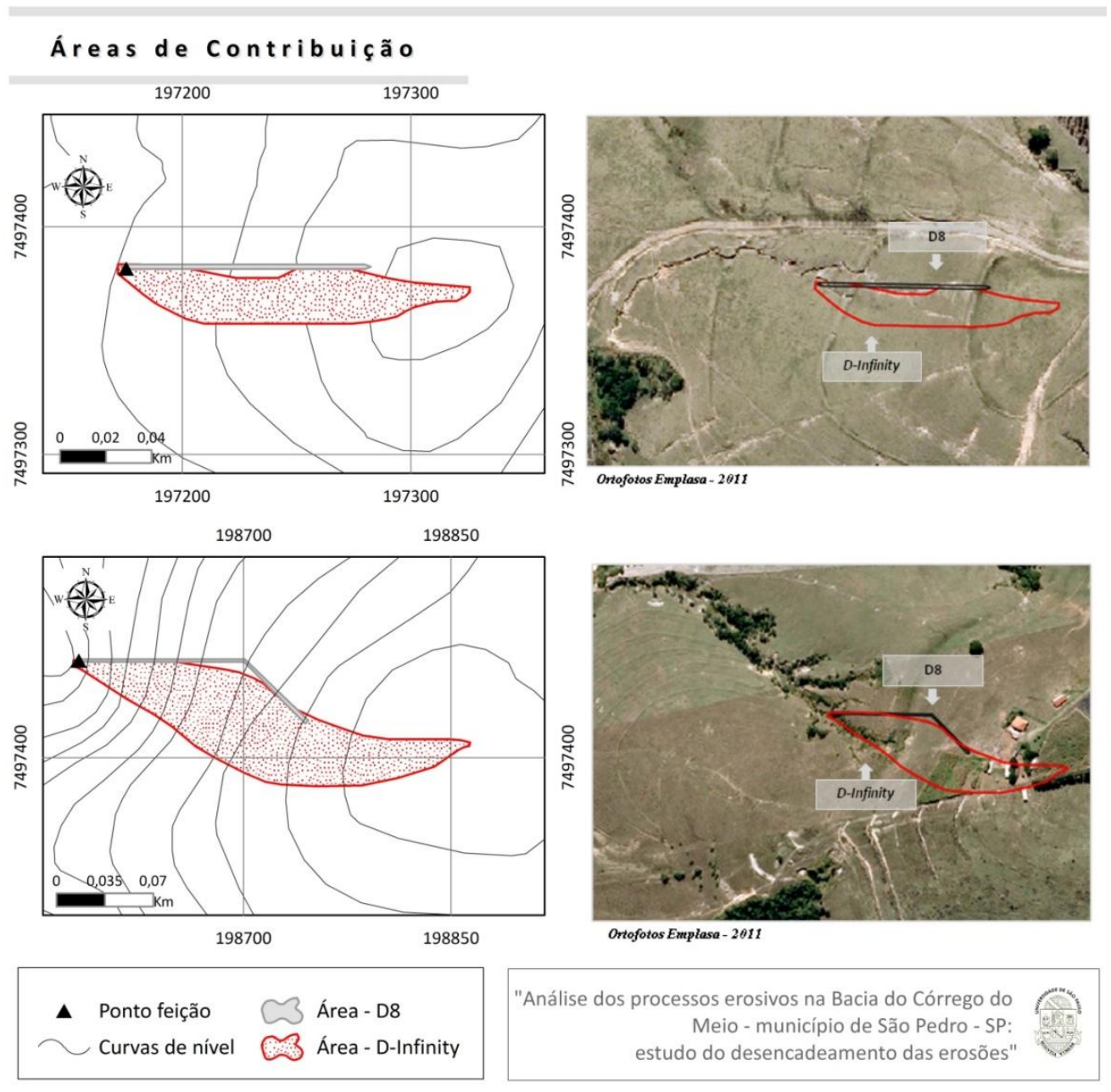


Observa-se que as áreas de contribuição definidas pelo D-Infinity são maiores e mais condizentes com a topografia e com as características físicas da área, como observado nas ortofotos. Isto mostra que os resultados obtidos com o método D-Infinity são mais realistas e permitem a determinação mais acurada das áreas de contribuição e declividades médias.

Outro aspecto importante é o posicionamento do limiar crítico do desencadeamento das erosões no gráfico SxA. Diferentemente de Araújo (2011), ao utilizar o D-Infinity para elaboração das áreas de contribuição foi possível realizar o ajuste do limiar crítico com base na linha de tendência, função potência no software Excel. Utilizando o D8, Araújo (2011) optou por um posicionamento empírico da reta para obtenção da equação $\mathrm{S} x \mathrm{~A}$, por não ter sido possível um ajuste matemático adequado.

$\mathrm{Na}$ análise comparativa de todos os índices de maneira geral, pode-se constatar que as diferenças entre os algoritmos se refletem sobremaneira na posição do limiar de desencadeamento e no valor de declividade crítica, o que se deve a representação espacial das áreas de contribuição.

\subsubsection{Refinamento do Modelo}

Como descrito no item anterior ao utilizar o D-Infinity foi possível obter alguns ganhos, como o ajuste do limiar crítico e determinação do índice a partir da linha de tendência. No entanto, os valores do $\mathrm{R}^{2}$ evidenciaram que existem outras variáveis que devem ser consideradas neste tipo de análise, com a finalidade de se obter índices mais específicos para a área em estudo.

Desta forma, buscou-se analisar de maneira mais detalhada características específicas das feições, levando-se em consideração não só a profundidade dos canais, como também a sua posição no relevo. Como descrito por Guerra (1998), as características relativas ao posicionamento das erosões em encostas atuam em conjunto com os fatores condicionantes, como erosividade da chuva e, propriedades do solo, que promovem maior ou menor resistência à erosão.

Verifica-se que a evolução das feições erosivas na Sub-Bacia dos Córregos dos Alpes e Retiro, apresenta relação direta conforme a sua posição no relevo, seja em áreas de encosta ou drenagem. Exemplificando, as erosões associadas à rede de drenagem, podem evoluir para processos mais complexos, tornando-se feições de relevo, o que dificultaria o processo de 
recuperação. Quando não estão conectadas a drenagem, as erosões tendem a ser menos profundas e podem ser recuperadas por práticas mais simples, como manejo agrícola.

Na literatura, autores como Vandekerckhove et al. (1998) analisaram o limiar de desencadeamento para feições divididas em dois grupos com base na localização no relevo: encostas (straight slope) ou vales (hollows). Neste contexto, decidiu-se fazer uma nova análise dos limiares considerando separadamente as feições erosivas de acordo com sua posição no relevo, sem fazer distinção quanto à profundidade (Figura 64).

Figura 64 - Critérios para classificação das feições.

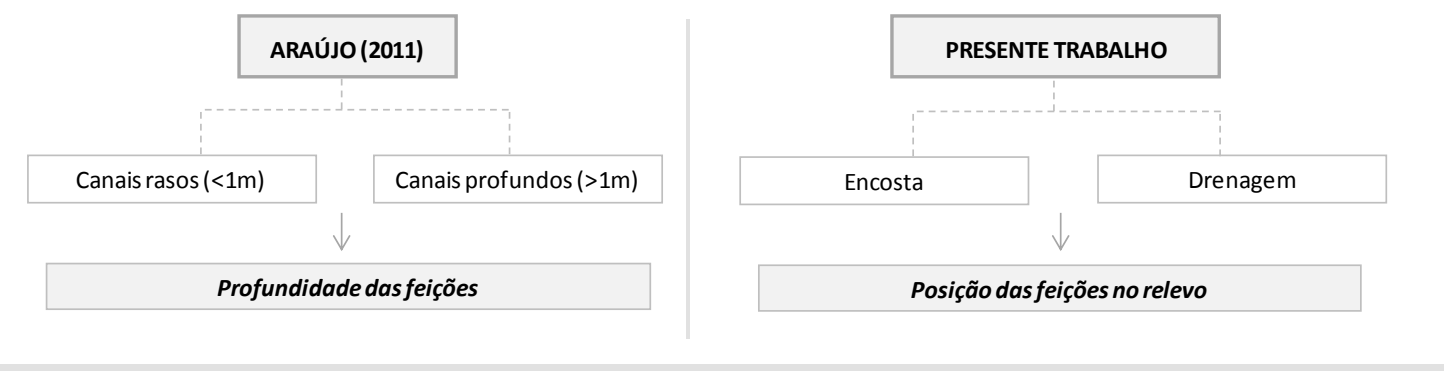

Todas as feições localizadas na Sub-Bacia do Córrego dos Alpes e Retiro foram subdividas em dois grupos: feições localizadas em encosta, e feições localizadas em drenagem. Para isto, foram analisadas as características das feições, por meio da interpretação das ortofotos (2011) em conjunto com o Mapa de landforms.

As feições localizadas em encostas ocorrem em áreas em que predominam os materiais transportados e residuais da Formação Pirambóia, e quanto ao uso e ocupação é representado por áreas de pastagem, cana-de-açúcar e eucalipto. Analisando as características da área em estudo e as imagens atuais, observa-se que estas feições apresentam relação direta com o uso agrícola intenso.

A Figura 65 apresenta o gráfico SxA para os pontos localizados em encosta, onde é possível observar que o limiar crítico está condicionado à declividade e área de contribuição menor. Ao aplicar o índice destas feições para uma área de 1 ha $\left(10.000 \mathrm{~m}^{2}\right)$ a declividade crítica que levaria ao desencadeamento das erosões seria de 5,18\% $(0,0518 \mathrm{~m} / \mathrm{m})$. 
Figura 65 - Gráfico SxA das feições localizadas em encosta.

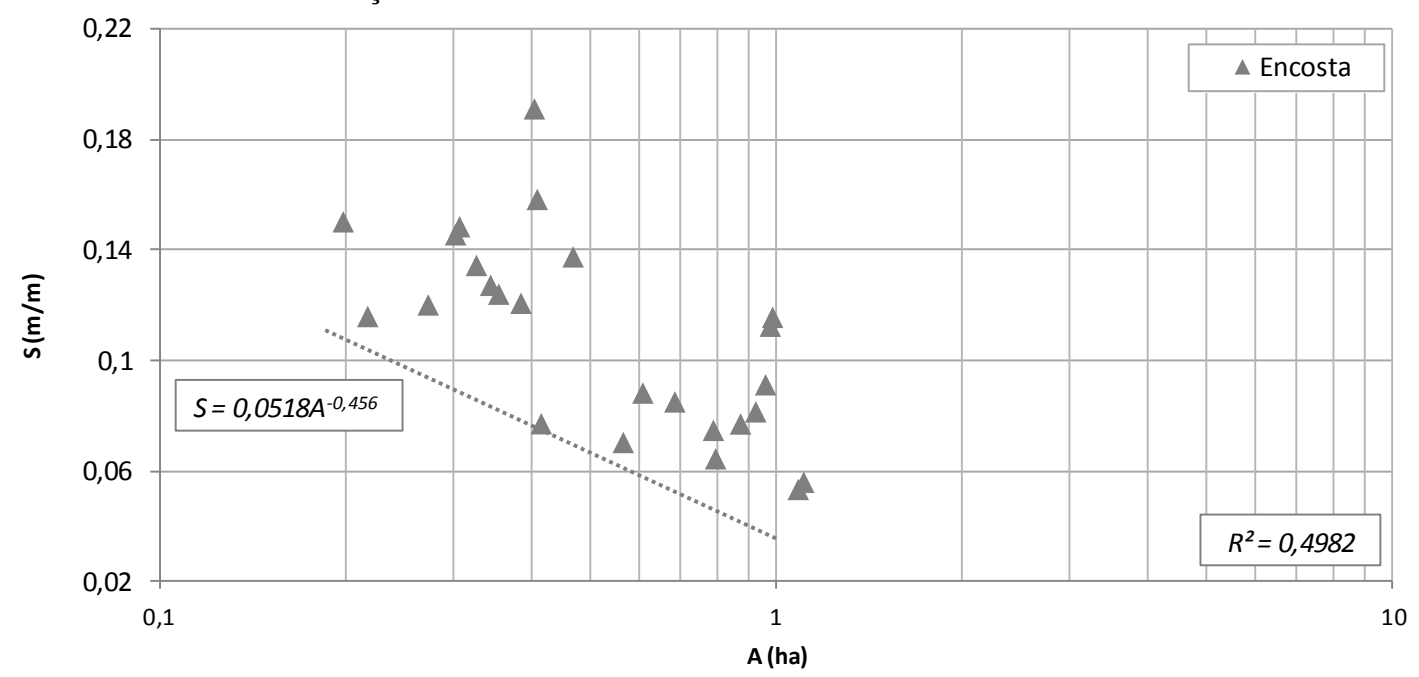

As áreas em que ocorrem as feições localizadas em drenagem apresentam as mesmas características geológicas e geomorfológicas, no entanto, a evolução destes canais pode estar associada à interferência antrópica, principalmente porque as maiores feições deste grupo (voçorocas) estão localizadas em área urbana. Ao analisar as imagens de satélite de 2016, constatou-se que estas feições ainda permanecem na sub-bacia, e estão associadas às áreas de pastagem e eucalipto.

Outra característica importante, é que estas feições estão conectadas à rede de drenagem, e por isso podem progredir gradualmente, para processos mais complexos. Estas regiões correspondem às partes mais baixas do relevo, que apresentam as zonas com maior concentração do fluxo acumulado.

A Figura 66 ilustra o gráfico SxA para as feições localizadas em drenagens, verifica-se que a inclinação da reta evidencia que o limiar de desencadeamento está associado a declividades mais elevadas. Aplicando-se o índice obtido para uma área de contribuição de 1 ha $\left(10.000 \mathrm{~m}^{2}\right)$ a declividade crítica que levaria ao surgimento destes canais seria de $10,41 \%$ $(0.1041 \mathrm{~m} / \mathrm{m})$. 
Figura 66 - Gráfico SxA das feições localizadas em drenagem.

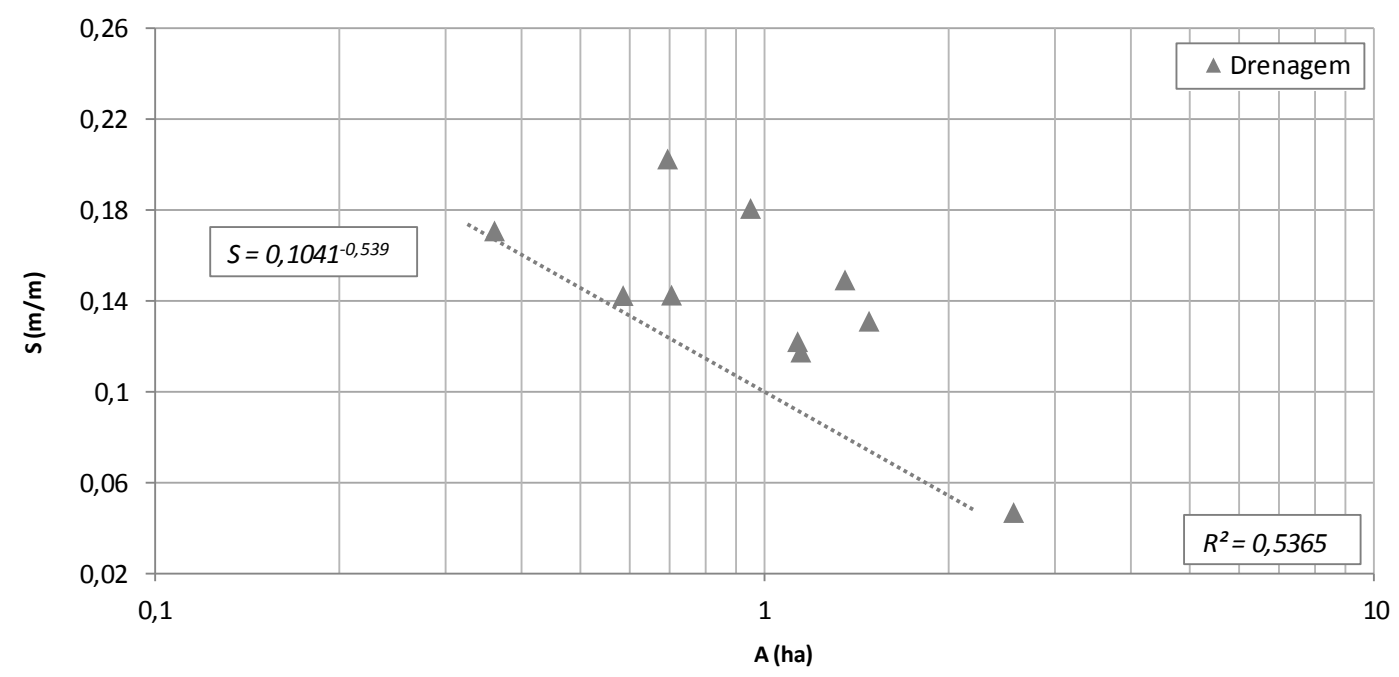

Quanto aos valores do $\mathrm{R}^{2}$, dos gráficos para os canais em encosta e drenagem, observa-se uma melhoria no ajuste dos dados, pois às condições geomorfológicas (posição no relevo) são mais similares. A Tabela 25 apresenta uma síntese destes valores, juntamente com os resultados das outras análises.

O refinamento dos dados descrito nesta etapa apresentou algumas vantagens em relação à correlação dos dados. No entanto, deve-se considerar que ainda existem outras variáveis envolvidas, como uso e ocupação, que condicionam o desencadeamento destas feições, e por isso devem ser analisadas com mais detalhe.

Tabela 25 - Valores do coeficiente de determinação $\left(\mathrm{r}^{2}\right)$ para diferentes análises, utilizando o D-Infinity.

\begin{tabular}{c|c}
\hline Característica das feições & $\mathbf{R}^{\mathbf{2}}$ \\
\hline Canais rasos & 0,1874 \\
\hline Canais profundos & 0,1676 \\
\hline Canais em encosta & 0,4982 \\
\hline Canais em drenagem & 0,5365 \\
\hline
\end{tabular}

Verifica-se que, a predição dos processos erosivos, utilizando $\mathrm{S} x \mathrm{~A}$ deve ser realizada ponderando as variáveis existentes, que refletem nos valores dos coeficientes $a$ e $b$, pois estes, estão relacionados com as características do meio (BEGIM; SCHUMM, 1979 e MONTGOMERY; DIETRICH, 1994). Portanto, a determinação do índice e o ajuste do limiar serão melhores quando analisadas feições com características semelhantes, como localização, geologia, e uso e ocupação.

Considerando os índices obtidos para a Sub-bacia do Córrego dos Alpes e Retiro, verifica-se alguns avanços com o uso do algoritmo D-Infinity, como: ajuste do índice e dos 
limiares críticos; melhor representação das áreas de contribuição em função da teoria do modelo de direção de fluxo; e valores de declividade crítica mais fidedignos, conforme as características da área em estudo.

\section{5 Índice SxA: Bacia do Córrego do Meio}

A análise do desencadeamento das erosões na Bacia do Córrego do Meio foi realizada considerando os 35 pontos de feições erosivas mapeados por Araújo (2011) e também os 23 pontos mapeados neste trabalho, totalizando 58 pontos. A determinação dos limiares críticos foi realizada em duas etapas: a primeira fase consistiu na elaboração do índice geral, analisando os pontos mapeados por Araújo (2011) e também aqueles mapeados no presente trabalho; e a segunda análise, mais detalhada, com base na posição dos canais no relevo.

\subsubsection{Análise Integrada}

Como apresentado no Mapa de Documentação, neste trabalho foram mapeados 23 novos pontos de feições erosivas, no entanto 6 destes estão localizados na região da Serra de Itaqueri (Figura 67), e apresentam condições morfométricas distintas das demais feições localizadas na área.

Figura 67 - Localização das feições na região da Serra de Itaqueri.

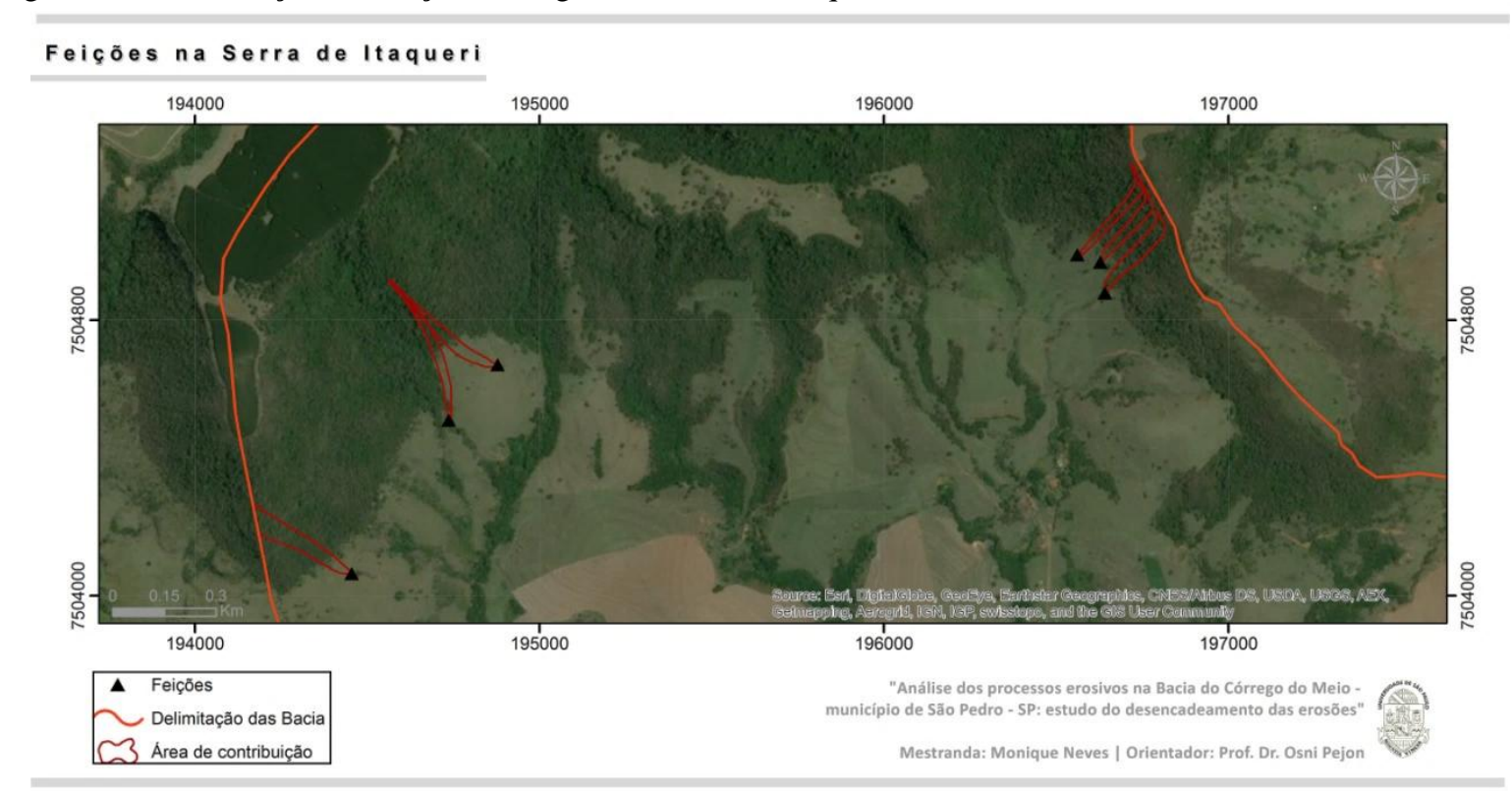

A região se caracteriza pela presença de encostas íngremes associadas a topos irregulares e angulosos, particularidade dos sistemas A e B de landforms; a geologia é composta por rochas das Formações Pirambóia e Botucatu; e os materiais inconsolidados são 
sedimentos coluvionares, materiais conglomeráticos e seixos associados aos arenitos e basaltos.

Além disso, especificamente no sistema de landforms "B" ocorrem processos de quedas de bloco e movimentos de massa. A Figura 68 apresenta o perfil topográfico destas encostas, no qual é possível verificar valores altos de elevação, que condicionam este tipo de processo e se refletem significativamente nos parâmetros morfométricos avaliados neste trabalho. Estas características diferem sobremaneira daquelas do restante da área que serviu de base para o desenvolvimento das equações dos limiares de erosão.

Desta forma com base no Mapa de Lanforms elaborado por Gomes (2002), optou-se por aplicar os índices apenas para as feições localizadas na região que engloba o Sistema de landforms $\mathrm{C}$, uma vez que a aplicação do método apresenta melhores resultados em áreas com características fisiográficas semelhantes. Este sistema corresponde a $80 \%$ da área da Bacia do Córrego do Meio, e se caracteriza por apresentar feições associadas às colinas médias e amplas, morrotes alongados e planícies aluviais, e geologia representada pela Formação Pirambóia. Portanto, foram utilizados nesta análise 52 pontos com feições erosivas.

Figura 68 - Perfil topográfico das encostas localizadas na Serra de Itaqueri.
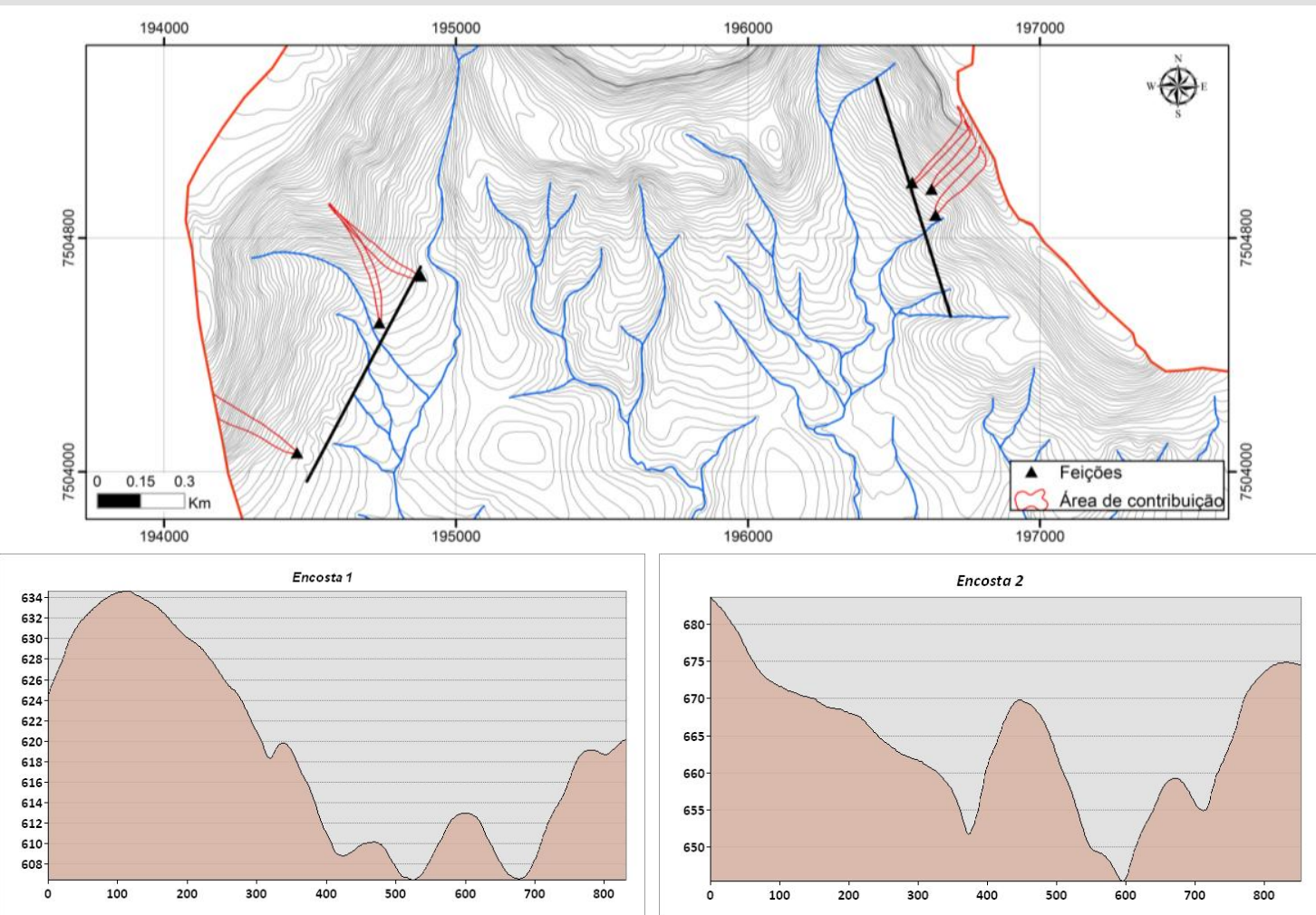
Considerando todas as feições localizadas na Bacia do Córrego do Meio realizou-se a análise integrada com todos dados com a finalidade de definir um limiar crítico geral para a área em estudo. A Figura 69 apresenta o gráfico com todos os pontos localizadas no sistema de landforms "C" e o índice SxA para a Bacia do Córrego do Meio.

Figura 69 - Gráfico SxA - Bacia do Córrego do Meio.

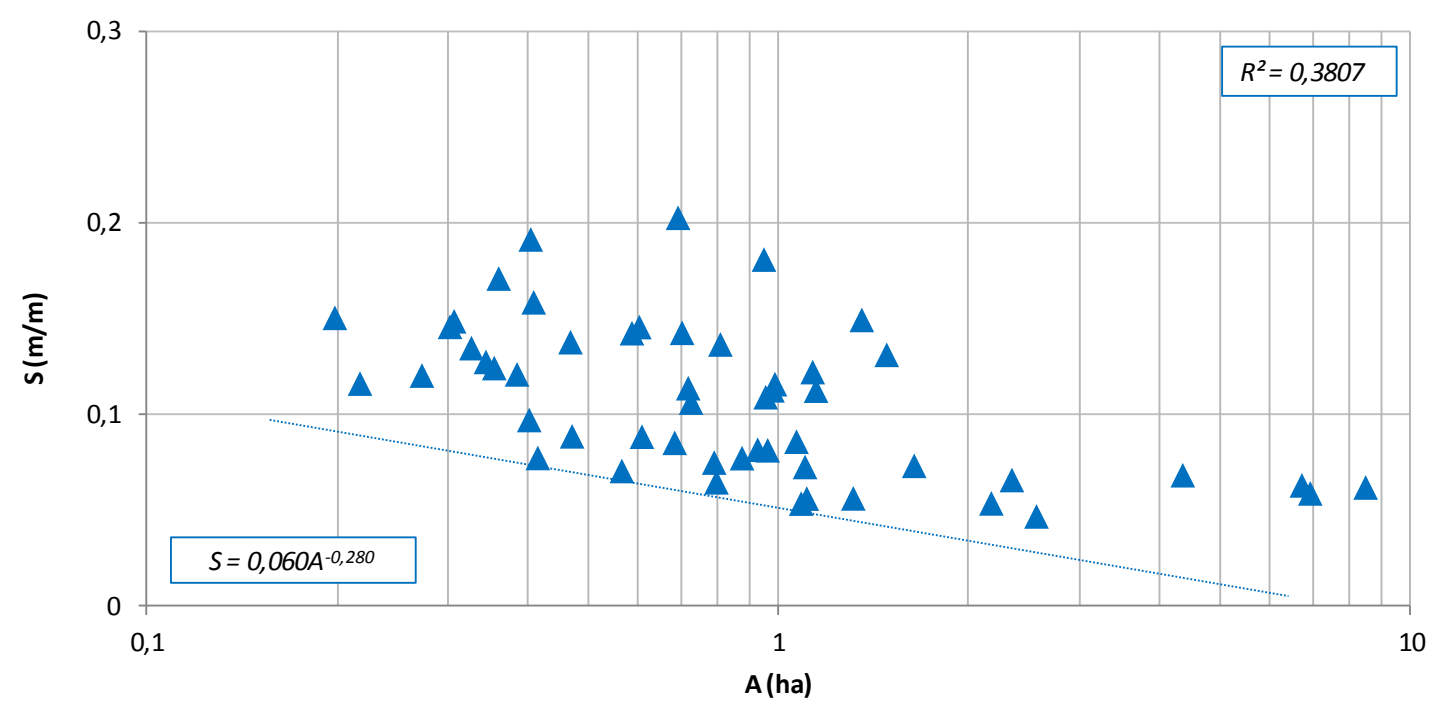

A declividade crítica que levaria o desencadeamento da erosão para uma área de contribuição de 1ha $\left(10.000 \mathrm{~m}^{2}\right)$ com este índice seria de $6,04 \%(0,0604 \mathrm{~m} / \mathrm{m})$, evidenciando que o desencadeamento dos processos na Bacia do Córrego do Meio ocorre em declividades relativamente baixas, portanto existem condições naturais que condicionam a ocorrência da erosão, como geologia e relevo.

O valor do $\mathrm{R}^{2}(0,3807)$ relativamente baixo se justifica, pois para esta análise foram consideradas todas as feições da área, que por sua vez apresentam características geomorfológicas e geológicas distintas. O limiar crítico foi ajustado no limite inferior dos dados, paralelamente à inclinação da linha de regressão gerada com a função potência, e se mostrou coerente, pois é possível verificar uma tendência de distribuição dos dados conforme o ajuste realizado.

5.5.1.1 Análise comparativa com os limiares propostos por Dietrich et al. (1992)

O limiar crítico para a área em estudo foi definido por meio do ajuste a partir das linhas de tendência, considerando apenas a relação existente entre declividade média e área de contribuição. Como apresentado na revisão bibliográfica, outra maneira de representar os limiares dos processos erosivos é utilizando o modelo proposto por Dietrich et al. (1992), que 
também relaciona área e declividade, no entanto, o posicionamento dos limiares é definido com base em equações que utilizam parâmetros geotécnicos e hidrológicos.

Como forma de avaliar o resultado do índice geral deste trabalho plotou-se o limiar crítico obtido no gráfico elaborado pelos autores citado, como pode ser observado na Figura 70. Verifica-se que o posicionamento do limiar crítico morfométrico ( $\mathrm{S} x \mathrm{~A})$ está próximo ao limiar de erosão linear, o que evidencia uma conformidade entre os métodos aplicados, mostrando que a relação estabelecida de maneira empírica está de acordo com as equações propostas pelos autores.

Embora o modelo dos autores tenha sido desenvolvido para condições do meio físico distintas das deste trabalho, percebe-se que há coerência entre os resultados e que seria possível aplicar o método proposto pelos autores, definindo os limiares críticos considerando também os parâmetros geotécnicos e hidrológicos. No entanto, para isso seria necessário a elaboração de um modelo hidrológico consistente, e a realização de ensaios, que permitissem a caracterização dos parâmetros geotécnicos para cada tipo de solo, conforme a escala de estudo. Também se torna fundamental considerar as características dos solos tropicais, principalmente a espessura, de maneira que os parâmetros utilizados estejam em conformidade com as características locais.

Figura 70 - Posicionamento do limiar critico no gráfico de Dietrich et al. (1992).
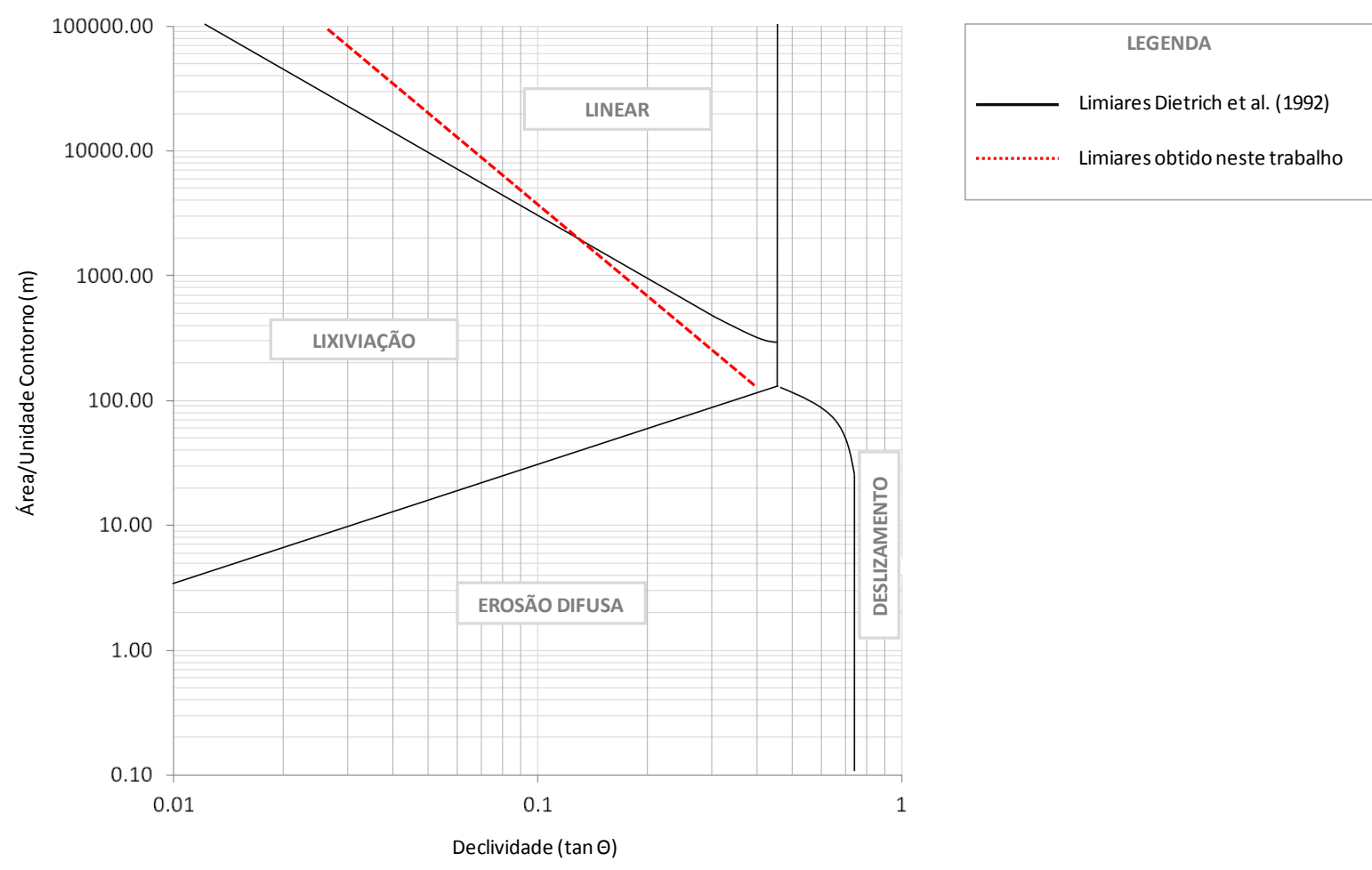


\subsubsection{Análise de acordo com a classificação das feições}

A análise detalhada do desencadeamento das erosões foi realizada considerando a posição das feições no relevo, conforme os resultados obtidos para a Sub-bacia do Córrego dos Alpes e Retiro. No entanto, considerando as especificidades de algumas feições, realizouse posteriormente uma subdivisão ponderando não só a localização, mas também a profundidade dos canais (Figura 71).

Figura 71 - Níveis de detalhamento para elaboração dos limiares críticos.

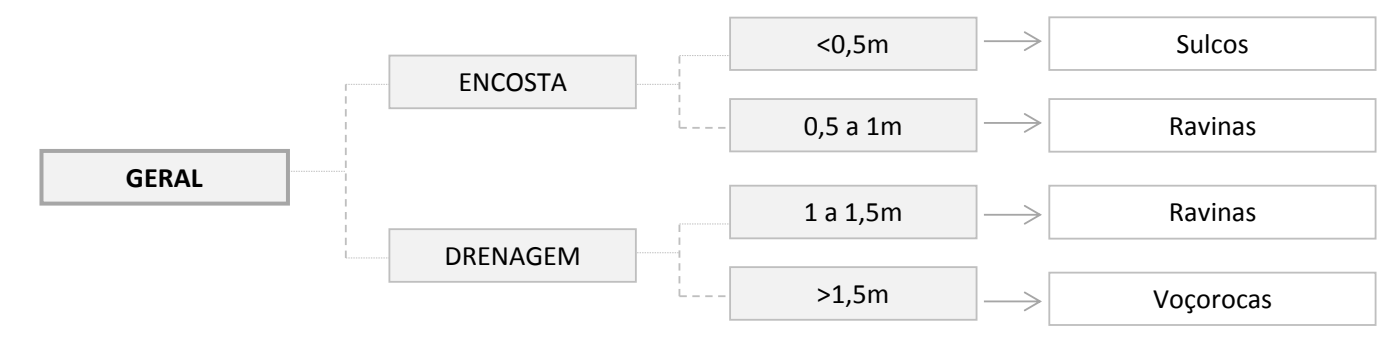

Desta maneira é possível detalhar os limiares dos processos erosivos considerando a posição dos canais no relevo e a profundidade, o que resulta em uma análise conforme os tipos de feições.

\subsubsection{Erosões em Encosta}

$\mathrm{Na}$ área em estudo foram mapeados 35 pontos de feições erosivas em encosta, sendo sulcos e ravinas localizadas em áreas de pastagem; cultura anual (cana-de-açúcar); e cultura temporária (eucalipto), algumas destas feições podem ser observadas na Figura 72.

Figura 72 - Feições localizadas em encosta.

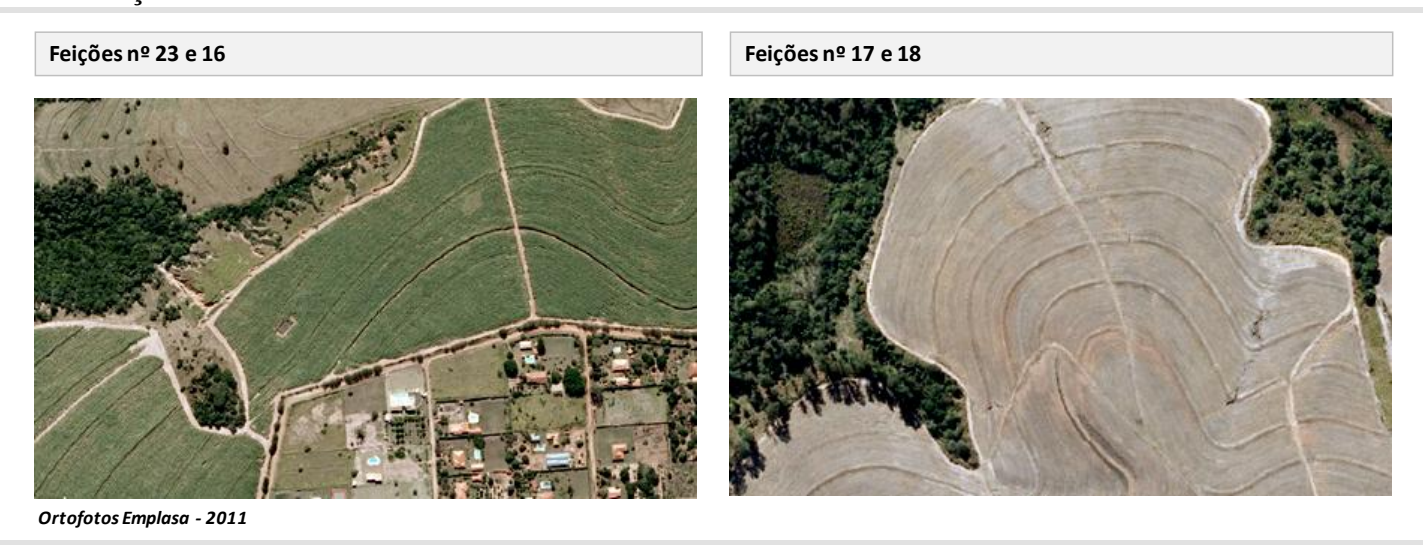


Considerando a análise temporal de 2011 a 2017, fica evidente que o surgimento destas erosões está associado a um conjunto de fatores, como manejo agrícola inadequado e períodos de chuva intensa.

A Figura 73 apresenta o gráfico SxA para estas feições. É possível notar que os valores de declividade média para os canais em encostas estão entre 5 e $15 \%$, e as áreas de contribuição são menores que 1 hectare, com exceção de três pontos de feições (outliers), que são ravinas com profundidade maiores, localizadas em encostas mais íngremes, que as demais.

Figura 73 - Gráfico SxA para as feições localizadas em encosta da Bacia do Córrego do Meio.

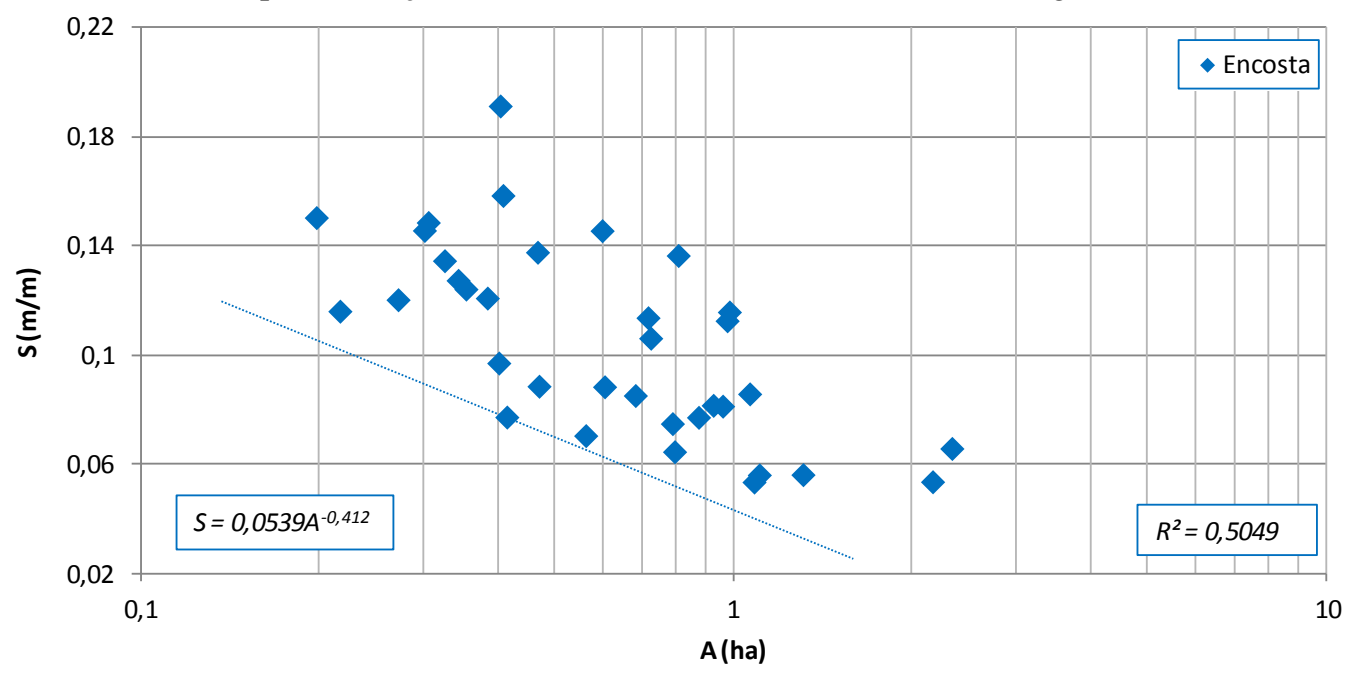

Aplicando-se o índice obtido para uma área de 1 ha $\left(10.000 \mathrm{~m}^{2}\right)$ o valor da declividade crítica que levaria ao desencadeamento das erosões seria de $5,39 \%(0,0539 \mathrm{~m} / \mathrm{m})$. O ajuste da linha de regressão resultou em um $\mathrm{R}^{2}$ de 0,5049 , que se mostra satisfatório, considerando as inúmeras variáveis existentes que podem interferir nos processos erosivos.

Para analisar estes canais de forma detalhada e propor limiares críticos mais específicos, dividiram-se estas feições em dois grupos: canais com profundidade menor que $0,5 \mathrm{~m}$, e canais com profundidade entre 0,5 a $1 \mathrm{~m}$. O gráfico da Figura 74 apresenta o resultado obtido com esta análise.

Para as feições com menos de $0,5 \mathrm{~m}$ de profundidade a declividade crítica que levaria ao desencadeamento obtida seria de 5,73\%, para uma área de 1 ha $\left(10.000 \mathrm{~m}^{2}\right)$. Este valor mostra-se coerente, pois as feições analisadas são sulcos localizados em encostas relativamente planas. Enquanto para as feições com profundidade entre 0,5 e 1m, o valor seria 
de $6,31 \%$, evidenciando que para o desencadeamento é necessário uma declividade maior, que se justifica, pois são feições do tipo ravinas.

Quanto aos valores do $\mathrm{R}^{2} \mathrm{o}$ ajuste se mostrou melhor para os canais com profundidade entre 0,5 e $1 \mathrm{~m}$. O valor relativamente baixo para os canais com profundidade menor que $0,5 \mathrm{~m}$, se justifica, pois o surgimento destes canais apresenta condições muito especificas, como práticas agrícolas e fluxo hídrico não concentrado, desta forma, como citado por Dietrich et al. (1993), a definição dos limiares críticos estão sujeitas a variações locais, que por sua vez, podem não apresentar relação direta com as condições morfométricas.

Figura 74 - Gráfico SxA para as feições localizadas em encosta conforme a profundidade dos canais.

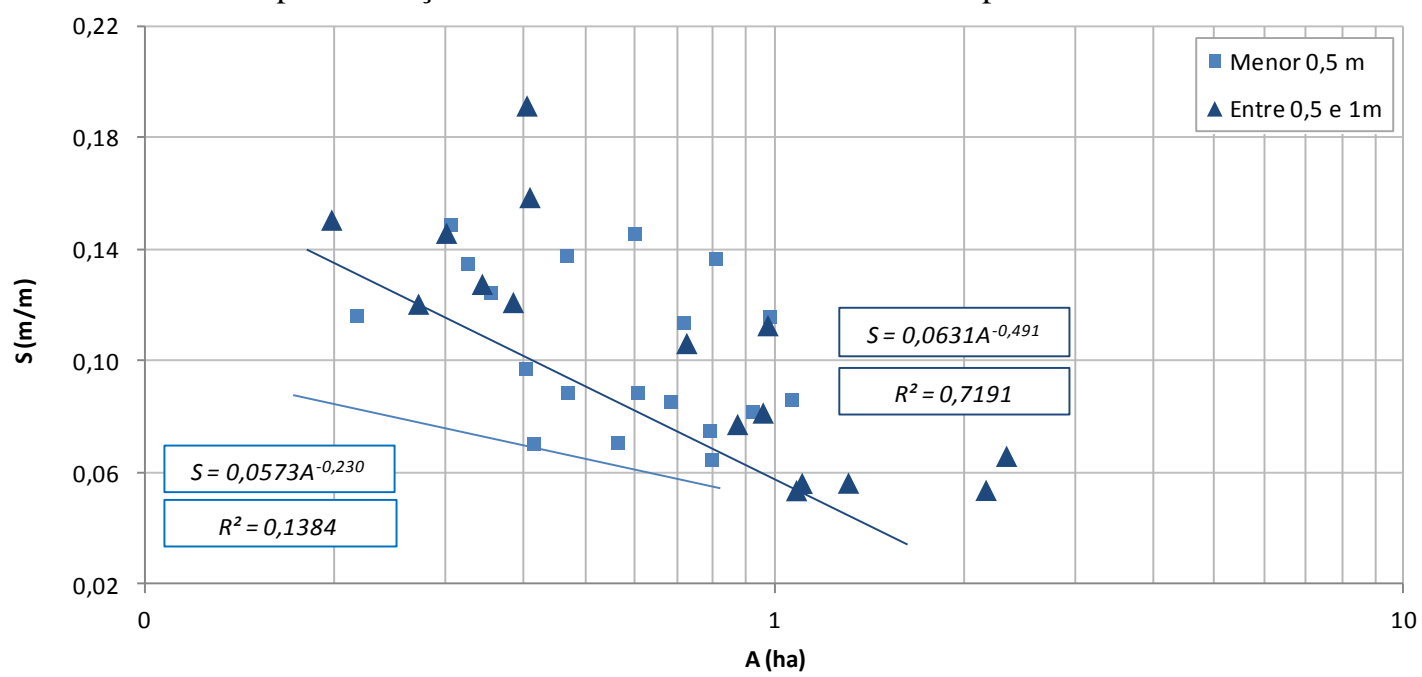

\subsubsection{Erosões em Drenagem}

Os canais localizados em drenagem são 17, sendo feições do tipo ravinas e voçorocas, localizadas em área urbana, área de pastagem, e cultura temporária (eucaliptos), ilustradas na Figura 75.

Como descrito no item (5.4.3) a evolução destes canais apresenta relação direta com a sua localização, as ravinas tendem a evoluir para voçorocas, que podem tornar-se feição de relevo, que por sua vez, comprometem as áreas urbanas e agrícolas, devido as altas taxas de perda de solo. 
Figura 75 - Feições localizadas em drenagem.

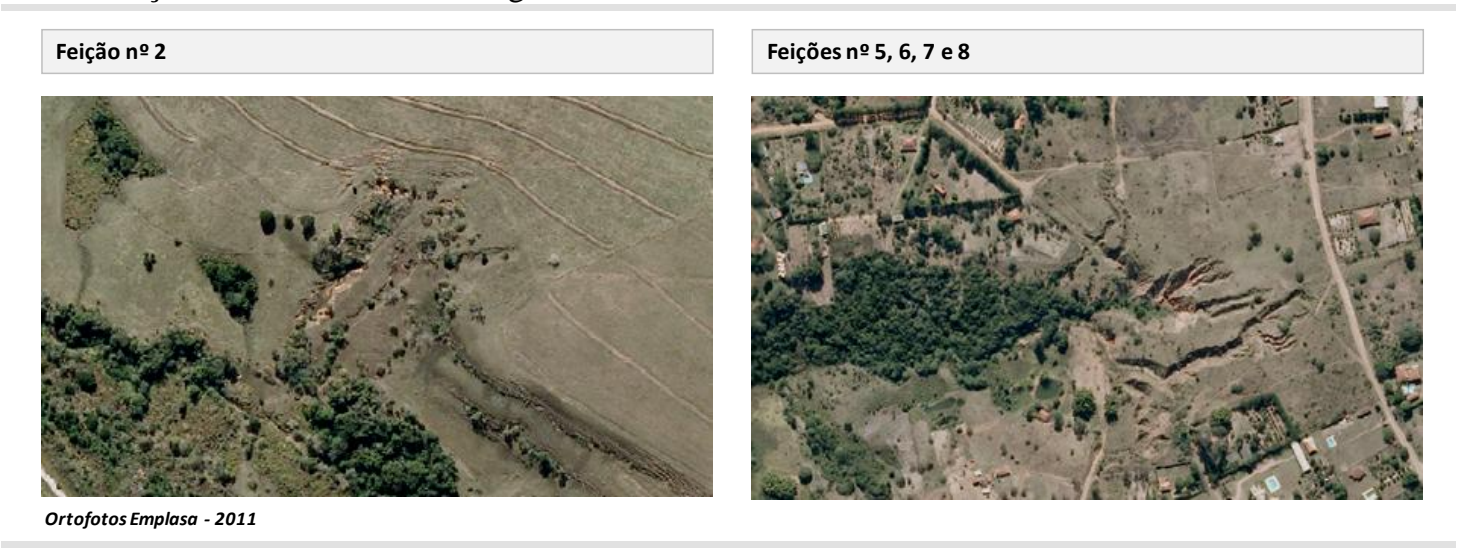

Diferente das feições localizadas em encosta, a declividade média e área de contribuição destas erosões são maiores, ocasionando consequentemente canais maiores em termos de área e profundidade. O gráfico $\mathrm{S} x \mathrm{~A}$ apresentado na Figura 76 revela estes valores.

Figura 76 - Gráfico SxA para as feições localizadas em drenagem da Bacia do Córrego do Meio.

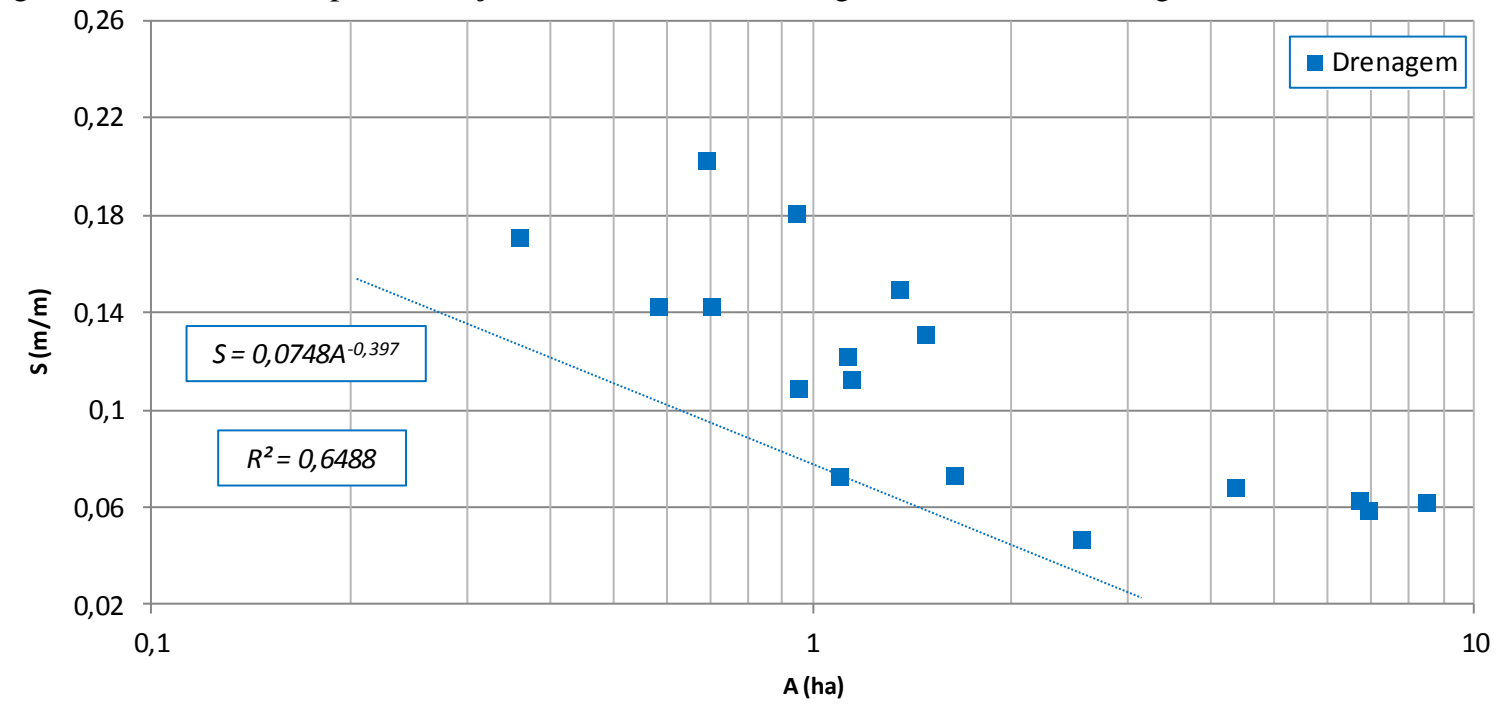

O índice obtido para uma área de 1 ha $\left(10.000 \mathrm{~m}^{2}\right)$ indica uma declividade crítica de $7,48 \%(0,0748 \mathrm{~m} / \mathrm{m})$. O R $\mathrm{R}^{2}$ obtido para a linha de regressão foi de 0,6488 , mostrando uma correlação consistente entre os dados analisados. Observa-se, que três pontos de feições (outliers) apresentam características distintas das demais, como localização e área de contribuição relativamente maior.

Para propor limiares críticos mais específicos para os canais localizados em drenagem, dividiram-se estas feições em dois grupos: canais com profundidade entre 1,0 a 1,5m, e canais com profundidade superior a 1,5m. O gráfico da Figura 77 apresenta o resultado obtido para está análise. 
A declividade crítica de desencadeamento das feições com profundidade entre $1 \mathrm{e}$ $1,5 \mathrm{~m}$ para uma área de contribuição de 1 ha $\left(10.000 \mathrm{~m}^{2}\right)$ é de $7,67 \%$. Este valor se deve a localização e ao tipo das feições, que são ravinas e estão situadas em vales fechados com inclinações maiores. Em relação aos canais com profundidade maior que 1,5m, a declividade crítica é de 11,96\%, que incide no desencadeamento de voçorocas, localizadas em encostas mais inclinadas, que ocasionam consequentemente maior concentração do escoamento superficial.

Em relação aos valores do $\mathrm{R}^{2}$, o ajuste apresentou resultados melhores para os canais com profundidade maior que $1,5 \mathrm{~m}$, pois todas as feições analisadas neste subgrupo são decorrentes de intervenção antrópica. Observa-se que o ajuste para as feições com profundidade entre 1,0 a $1,5 \mathrm{~m}$ foi menor, portanto, conclui-se que para definir características especificas das feições, com a finalidade de melhorar as condições de contorno, se torna necessárias informações mais precisas, que requerem levantamento em campo.

Figura 77 - Gráfico SxA para as feições localizadas em drenagem conforme a profundidade dos canais.

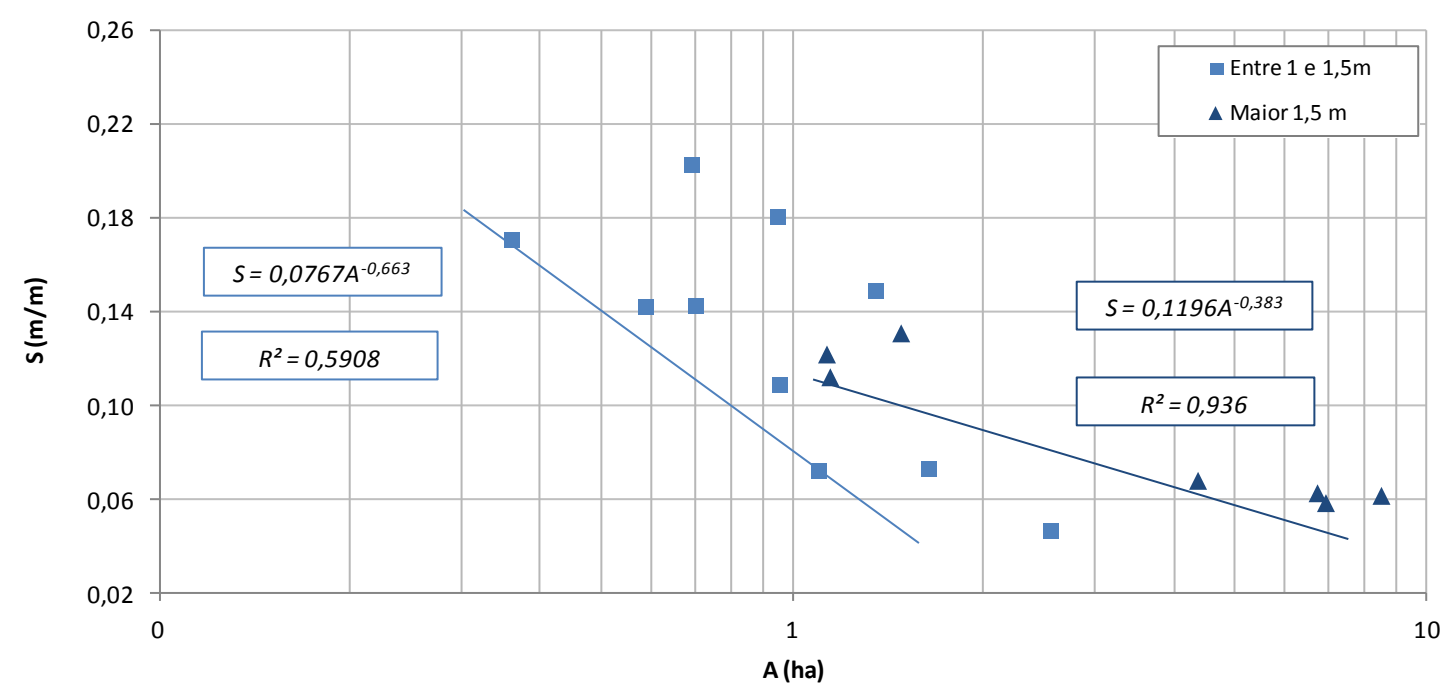

A Tabela 26 sintetiza os principais índices obtidos para a Bacia do Córrego do Meio e os valores de declividade crítica. Os índices obtidos favoreceram a análise do desencadeamento dos processos erosivos na Bacia do Córrego do Meio, permitindo a definição de aspectos importantes como, declividade crítica associadas a estes limiares. Tais valores mostraram-se coerentes com as características da área, principalmente com as unidades de landforms. A elaboração dos mapas utilizando o algoritmo D-Infinity permitiu um melhor ajuste dos dados, o que favoreceu a determinação dos diferentes limiares críticos. 
Verifica-se também que, outras características especificas das feições podem ser consideradas para melhorar o ajuste dos dados analisados, no entanto, para que os dados estejam coerentes, se torna fundamental o levantamento de campo, e este trabalho foi realizado com o propósito de obter o maior número de informações possível por meio de dados remotos, como imagens de satélite e ortofotos.

Tabela 26 - Índices SxA para a Bacia do Córrego do Meio.

\begin{tabular}{c|c|c|c|c}
\hline Característica & Profundidade & Índice & $\mathbf{S}_{\text {crítico }}$ & $\mathbf{R}^{\mathbf{2}}$ \\
\hline Análise integrada & - & $\mathrm{S}=0,0600 \mathrm{~A}^{-0,280}$ & $6,04 \%$ & 0,3807 \\
\hline \multirow{3}{*}{ Erosões em encosta } & - & $\mathrm{S}=0,0539 \mathrm{~A}^{-0,412}$ & $5,39 \%$ & 0,5049 \\
\cline { 2 - 5 } & $<0,5 \mathrm{~m}$ & $\mathrm{~S}=0,0573 \mathrm{~A}^{-0,230}$ & $5,73 \%$ & 0,1384 \\
\cline { 2 - 5 } & $0,5 \mathrm{a} 1 \mathrm{~m}$ & $\mathrm{~S}=0,0631 \mathrm{~A}^{-0,491}$ & $6,31 \%$ & 0,7191 \\
\hline \multirow{3}{*}{ Erosões em drenagem } & - & $\mathrm{S}=0,0748 \mathrm{~A}^{-0,397}$ & $7,48 \%$ & 0,6488 \\
\cline { 2 - 5 } & $1 \mathrm{a} 1,5 \mathrm{~m}$ & $\mathrm{~S}=0,0767 \mathrm{~A}^{-0,663}$ & $7,67 \%$ & 0,5908 \\
\cline { 2 - 5 } & $>1,5 \mathrm{~m}$ & $\mathrm{~S}=0,1196 \mathrm{~A}^{-0,383}$ & $11,96 \%$ & 0,9360 \\
\hline
\end{tabular}

\subsection{Zoneamento de Áreas de Ocorrência de Erosões com base nos limiares topográficos}

A Carta de Zoneamento de Áreas de Ocorrência de Erosões consiste na representação cartográfica das áreas críticas definidas a partir da relação entre a Carta de Declividades e o Mapa de Área de Contribuição. Desta forma, foram elaboradas três cartas: Carta de Zoneamento de Áreas de Ocorrência de Erosões; Carta de Zoneamento de Áreas de Ocorrência de Erosões em Encosta; e Carta de Zoneamento de Áreas de Ocorrência de Erosões em Drenagem.

Assim como os índices $\mathrm{S} x \mathrm{~A}$, as cartas de zoneamento foram elaboradas apenas para a região da bacia que compõem o sistema de landforms $\mathrm{C}$, por apresentar características fisiográficas semelhantes. Os demais sistemas (A e B), região da Serra de Itaqueri são compostos por encostas íngremes e terrenos com declividade alta, que desfavorece a aplicação da relação morfométrica para mapeamento das áreas críticas.

\subsubsection{Geral}

As áreas com possibilidade de ocorrência de feições erosivas laminares do tipo sulcos, ravinas e voçorocas, ocorrem em encostas retilíneas e vertentes convexas, com topos arredondados; e alta densidade de canais, conforme o Mapa de landforms (GOMES, 2002). Estas características condicionam zonas de fluxo acumulado e consequentemente o desencadeamento das erosões. 
A partir da Carta de Zoneamento de Áreas de Ocorrência de Erosões elaborada pela equação do índice geral $\left(\mathrm{S}=0,06 \mathrm{~A}^{-0,280}\right)$, verifica-se que as áreas críticas delimitadas espacialmente correspondem a $14,42 \%$ da área considerada para aplicação dos índices (landform C), e mostram conformidade com os pontos de feições erosivas. Estas áreas ocorrem em vales onde a concentração do fluxo acumulado é maior, que por sua vez estão associados aos terrenos com declividade elevada. Destacam-se as áreas críticas localizadas nas Sub-Bacia dos Córregos dos Alpes e Retiro, como a região com maior concentração em toda a bacia em estudo.

Como citado por Dietrich et al. (1993) e Stabile (2013), os pontos de feições erosivas que não estão próximos das áreas críticas indicam que a elaboração dos índices está sujeita a variabilidade das características das feições, ou seja, o desencadeamento destes canais pode estar relacionado com algumas propriedades especificas, que por sua vez estão relacionadas com os processos de transporte de sedimentos difusos. A Figura 78 apresenta de forma detalhada as áreas críticas e os pontos de feições erosivas.

Figura 78 - Representação detalhada das áreas críticas.
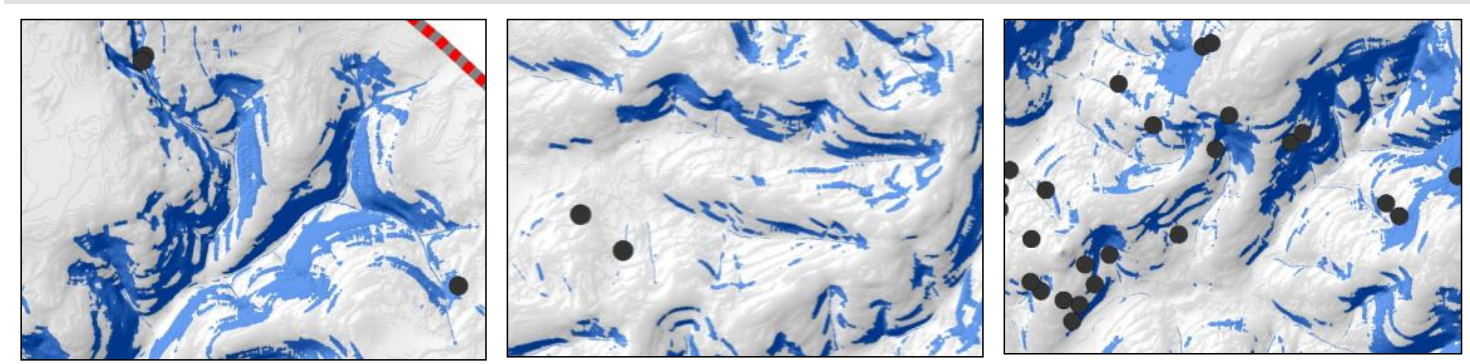

Áreas criticas

Pontos feições

A Figura 79 apresenta a Carta de Zoneamento de Áreas de Ocorrência de Erosões da Bacia do Córrego do Meio. O processamento dos dados em SIG e a expressão utilizada se mostraram coerentes e permitiram a representação espacial dos limites críticos, e consequentemente a identificação das áreas críticas. Como citado por Gutiérrez et al. (2009) estas cartas auxiliam a compreensão dos processos de evolução das feições e podem ser aplicados em conjunto com as técnicas de conservação do solo, auxiliando desta forma o planejamento ambiental da área. 
Figura 79 - Carta Geral de Zoneamento de Áreas de Ocorrência de Erosão.

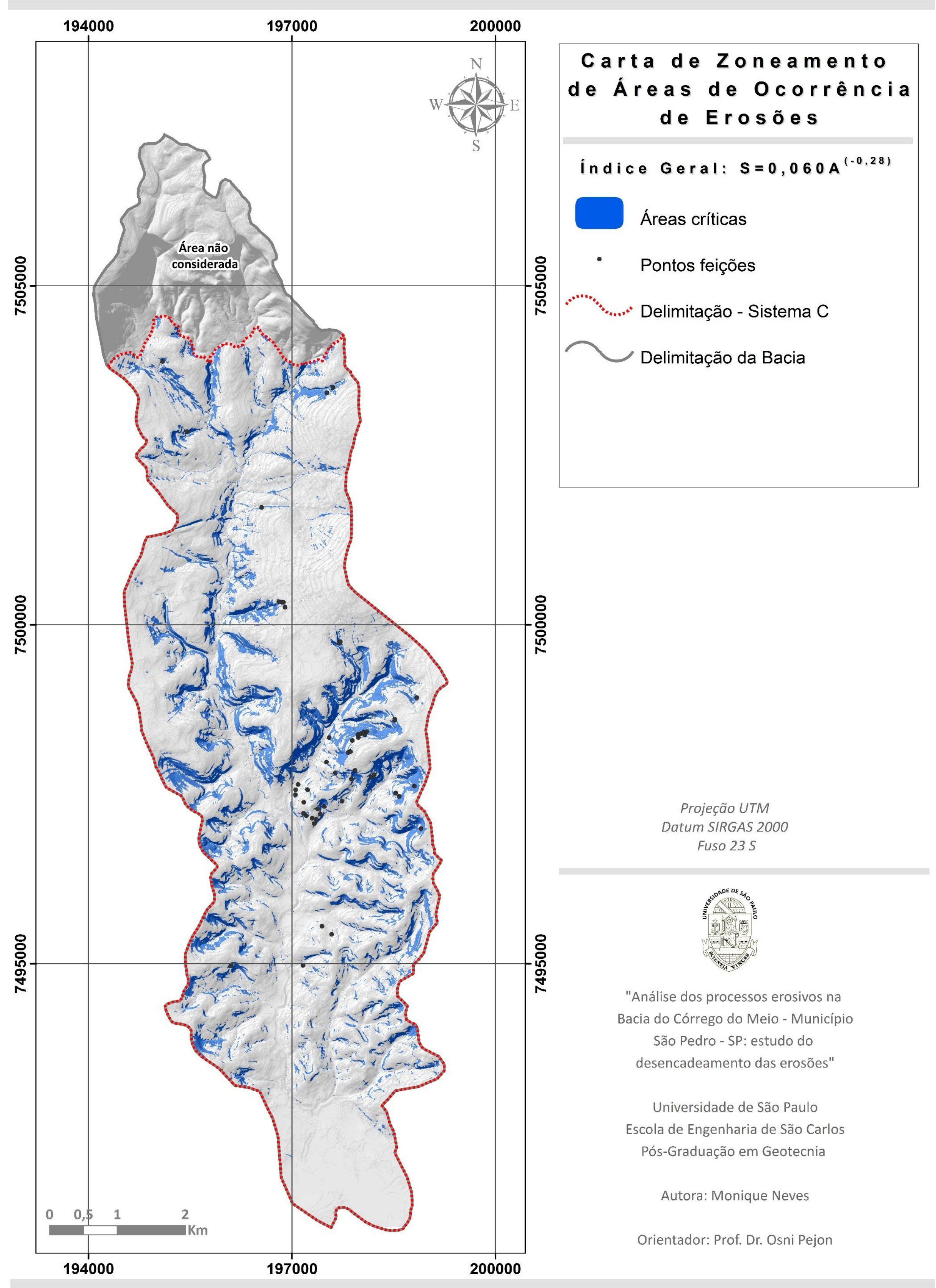





\subsubsection{Erosões em Encosta}

As áreas críticas que condicionam o desencadeamento das erosões em encostas, principalmente sulcos e ravinas, canais com profundidades menores, ocorrem em encostas convexas de topos arredondados e vales fechados, que correspondem às unidades $\mathrm{C} 4, \mathrm{C} 5$ e C7 do Mapa de Landforms.

Em termos percentuais as áreas críticas ocorrem em 5,29\% da área da Bacia do Córrego do Meio, e estão em conformidade com a maioria dos pontos mapeados, como pode ser constatado na Carta de Zoneamento de Áreas de Ocorrência de Erosões em Encosta $\left(\mathrm{S}=0,0539 \mathrm{~A}^{-0,412}\right)$, ilustrada na Figura 80 .

Observa-se que estas áreas críticas delimitadas no mapa ocorrem nas regiões onde existem terrenos com declividade moderada que coincidem com as maiores classes do mapa de área de contribuição.

Verifica-se que, para alguns pontos de erosões, não é possível observar áreas críticas no entorno, e sim pequenos canais de fluxo acumulado, isto indica, que o desencadeamento das erosões depende não apenas da declividade e do fluxo acumulado, parâmetros correlacionados na carta, mas também das condições de uso e ocupação e manejo agrícola.

\subsubsection{Erosões em Drenagem}

As áreas críticas de erosão em drenagem estão localizadas nas margens dos canais e nas unidades de landforms com alta densidade de drenagem (C4, C5 e C9). Estas características estão condizentes com os pontos mapeados, que se caracterizam por canais profundos, que podem expandir lateralmente, tornando-se feições de relevo, em uma determinada evolução temporal.

A Figura 81 apresenta a Carta de Zoneamento de Áreas de Ocorrência de Erosões em Drenagem $\left(S=0,0714 \mathrm{~A}^{-0,397}\right)$, em termos percentuais as áreas críticas correspondem a $2,66 \%$ da área considerada (landform C). Os valores em termos percentuais são baixos, o que se justifica, pois, na elaboração da carta foram correlacionados os parâmetros área de contribuição e declividade, e por isso, as áreas identificadas são apenas as regiões da bacia onde a declividade elevada coincide com as áreas com maior concentração de fluxo. 
Assim como na Carta de Zoneamento de Áreas de Ocorrência de Erosões em Encosta, os pontos que não apresentam áreas mapeadas em seu entorno, indicam que o desencadeamento da feição está relacionado também com aspectos antrópicos, como áreas urbanizadas e ruas não pavimentadas, que acabam direcionando o escoamento superficial para as erosões. 
Figura 80 - Carta de Zoneamento de Áreas de Ocorrência de Erosões em Encosta.

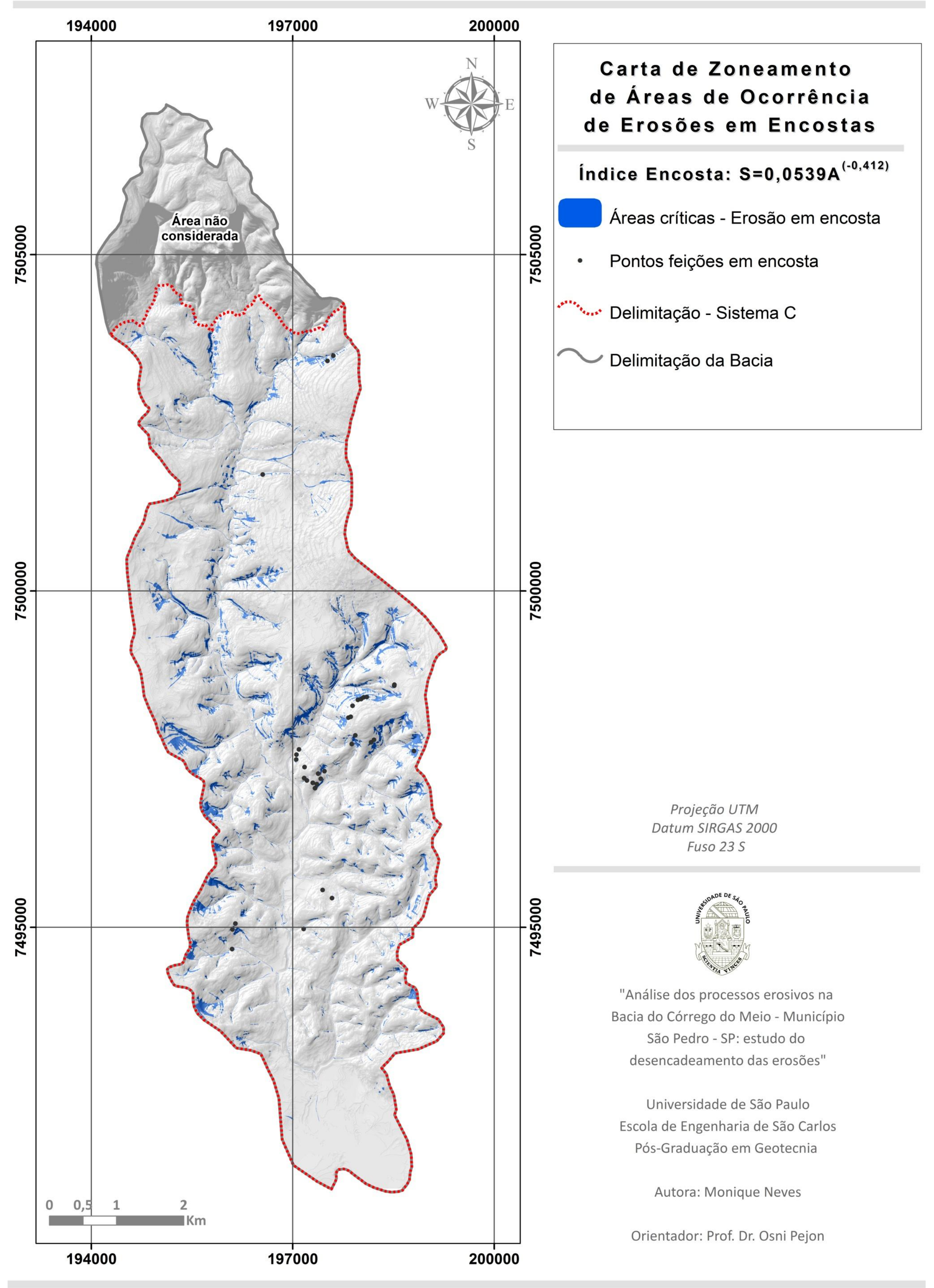



Figura 81 - Carta de Zoneamento de Áreas de Ocorrência de Erosões em Drenagem.

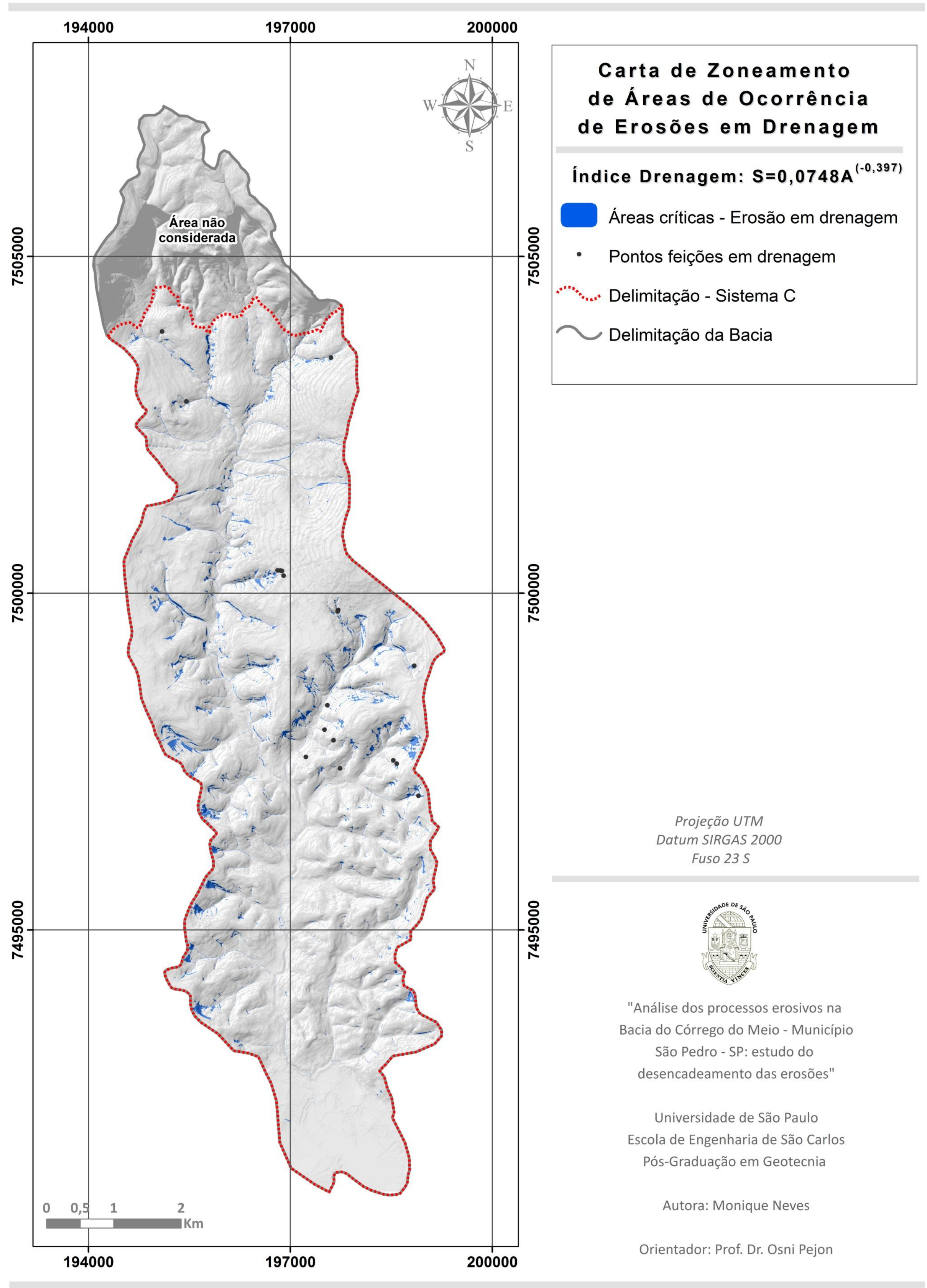





\subsubsection{Comparação das Cartas de Zoneamento com a Carta de Susceptibilidade}

A avaliação das Cartas de Zoneamento de Áreas de Ocorrência de Erosões definidas com base nas equações dos limiares topográficos foi realizada por meio da confrontação com documentos cartográficos elaborados previamente. Para isto, utilizou-se a Carta de Susceptibilidade à Erosão da Bacia do Córrego do Meio na escala de 1:20.000, elaborada por Gomes (2002).

\subsubsection{Carta de Susceptibilidade à Erosão}

A Carta de Susceptibilidade à Erosão da Bacia do Córrego do Meio foi elaborada por Gomes (2002) a partir dos seguintes atributos do meio físico: landforms, materiais inconsolidados, substrato rochoso e declividade. Ponderando estes planos de informação em uma matriz de comparação pareada AHP - Analytc Hierarchy Process (SAATY, 1980), a autora definiu cinco classes de susceptibilidade à erosão em função das características do meio físico e sua representatividade, descritas na Tabela 27.

Tabela 27 - Classes de susceptibilidade definidas por Gomes (2002).

\begin{tabular}{c|l}
\hline Classes & \multicolumn{1}{c}{ Características } \\
\hline \multirow{3}{*}{ Muito pouco susceptível } & $\begin{array}{l}\text { Terrenos planos e extensos, que correspondem às unidades A1, C3, C8 e C12. } \\
\text { Nestas áreas há presença de cobertura vegetal, que protegem o solo e reduzem o } \\
\text { gradiente do escoamento superficial. }\end{array}$ \\
\hline Touco susceptíveis & $\begin{array}{l}\text { Terrenos com baixa declividade e compostos por materiais de baixo índice de } \\
\text { erodibilidade. As feições erosivas, do tipo sulcos, surgem devido ao escoamento } \\
\text { superficial concentrado nas trilhas de animais. }\end{array}$ \\
\hline Moderadamente & $\begin{array}{l}\text { Ocorrem em terrenos com declividade superior a 5\% e materiais com baixa coesão, } \\
\text { de textura arenosa. Correspondem à porção intermediária da Bacia do Córrego do } \\
\text { Meio, e as feições erosivas do tipo, sulcos e ravinas surgem devido às condições de } \\
\text { relevo que favorecem o escoamento superficial concentrado. }\end{array}$ \\
\hline Susceptíveis & $\begin{array}{l}\text { Incidem em áreas próximas as drenagens, em terrenos com inclinação superior a } \\
10 \% \text { e com forte interferência antrópica, que aceleraram os processos erosivos. } \\
\text { Nestas áreas há ocorrência de feições desde sulcos a voçorocas, devido à ação } \\
\text { combinada do escoamento superficial e subsuperficial }\end{array}$ \\
\hline Muito susceptíveis & Ocorrem em terrenos muito inclinado, localizados próximos as redes de drenagem. \\
\hline
\end{tabular}

A distribuição destas classes para a Bacia do Córrego do Meio em valores percentuais está ilustrada na Figura 82. Observa-se que as classes menos susceptíveis correspondem a 47,4\%, e as classes mais susceptíveis estão distribuídas em 52,6\% da área, nestas áreas a ocorrência dos processos erosivos, se torna um problema ambiental crítico, devido à extensão das feições. 
Figura 82 - Percentual de ocorrência das classes de susceptibilidade.

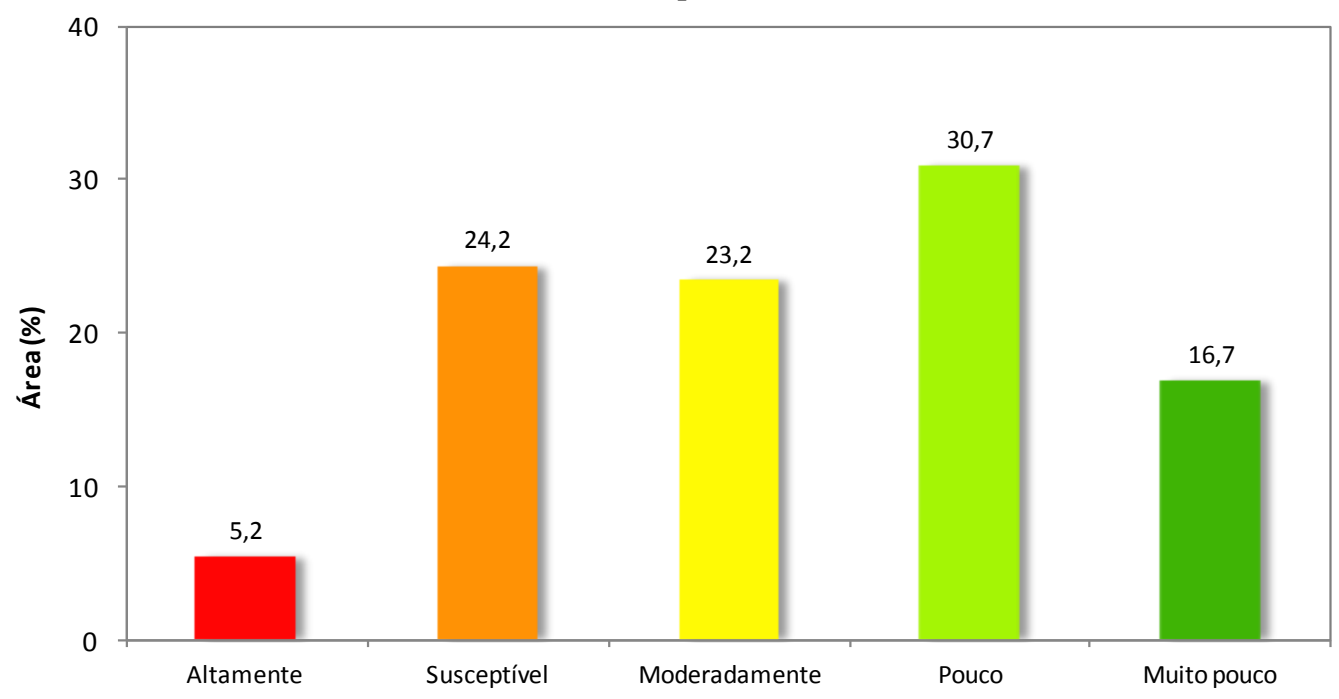

A Figura 83 apresenta a Carta de Susceptibilidade à Erosão digitalizada no ArcGIS, a partir da carta original produzida por Gomes (2002). Ressalta-se, que existem pequenas diferenças em termos de valores percentuais desta carta com a contabilizada por Gomes (2002) devido ao processo de digitalização do arquivo, no entanto, esta diferença não interferiu nas análises realizadas.

Observa-se que as classes menos susceptíveis ocorrem em terrenos planos, onde há menor interferência das atividades antrópicas. Na porção central da área ocorrem as classes mais susceptíveis, que por sua vez estão associadas a intervenções antrópica, como: desmatamento, áreas urbanizadas, vias de acesso e áreas agrícolas, que em conjunto com as características do meio físico, aceleram ou propiciam a formação dos processos erosivos. 
Figura 83 - Carta de Susceptibilidade à Erosão de Gomes (2002).

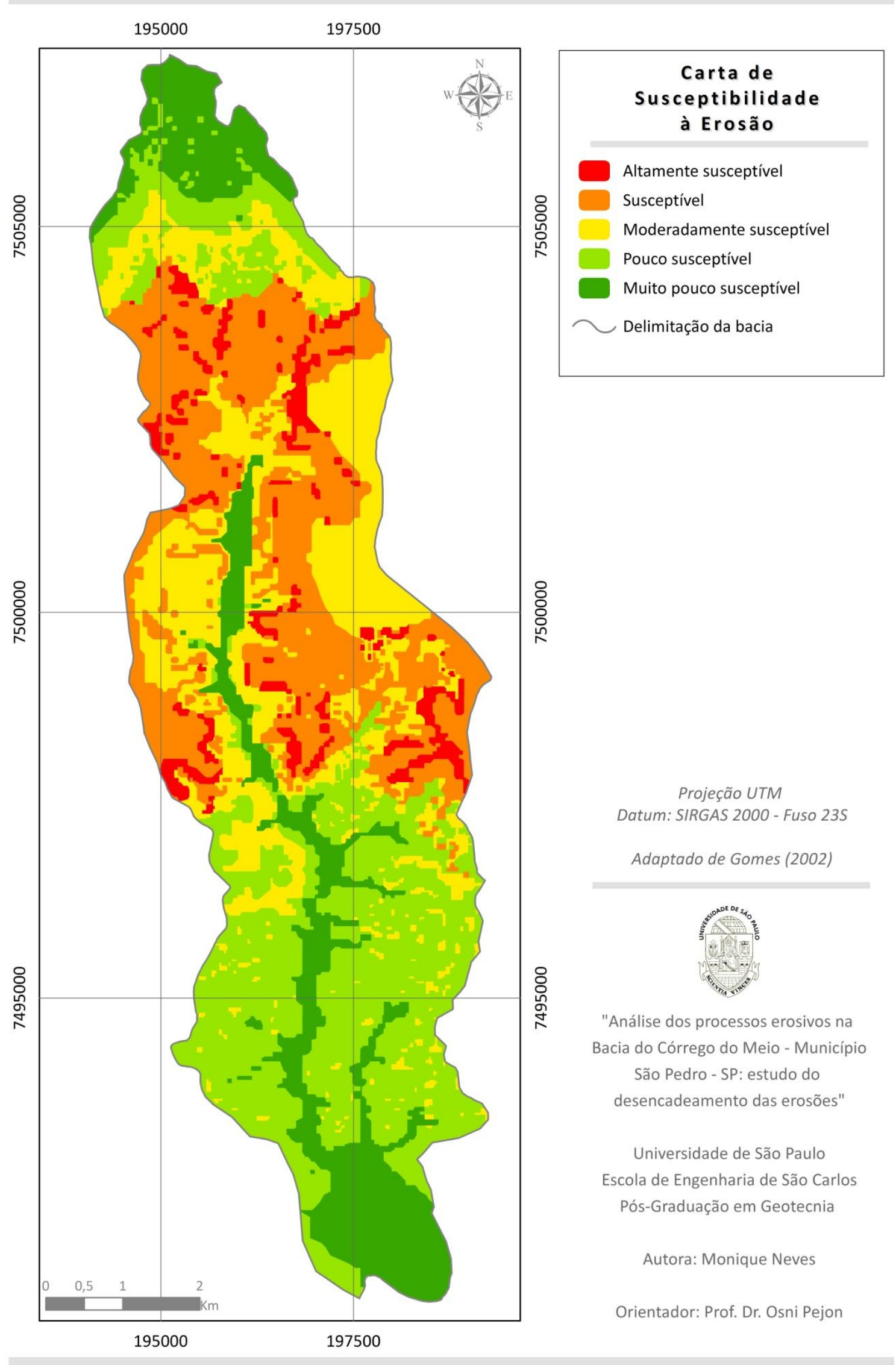


A Figura 84 apresenta uma das feições que ocorrem nas classes susceptível e altamente susceptível. Esta voçoroca se caracteriza como um processo ativo e com presença de piping e localiza-se em área de chacreamento. Foi possível verificar em campo que a presença de ruas não pavimentadas e ausência de obras de microdrenagem, favorecem a evolução deste processo.

Figura 84 - Processo erosivo localizado em área de chacreamento.
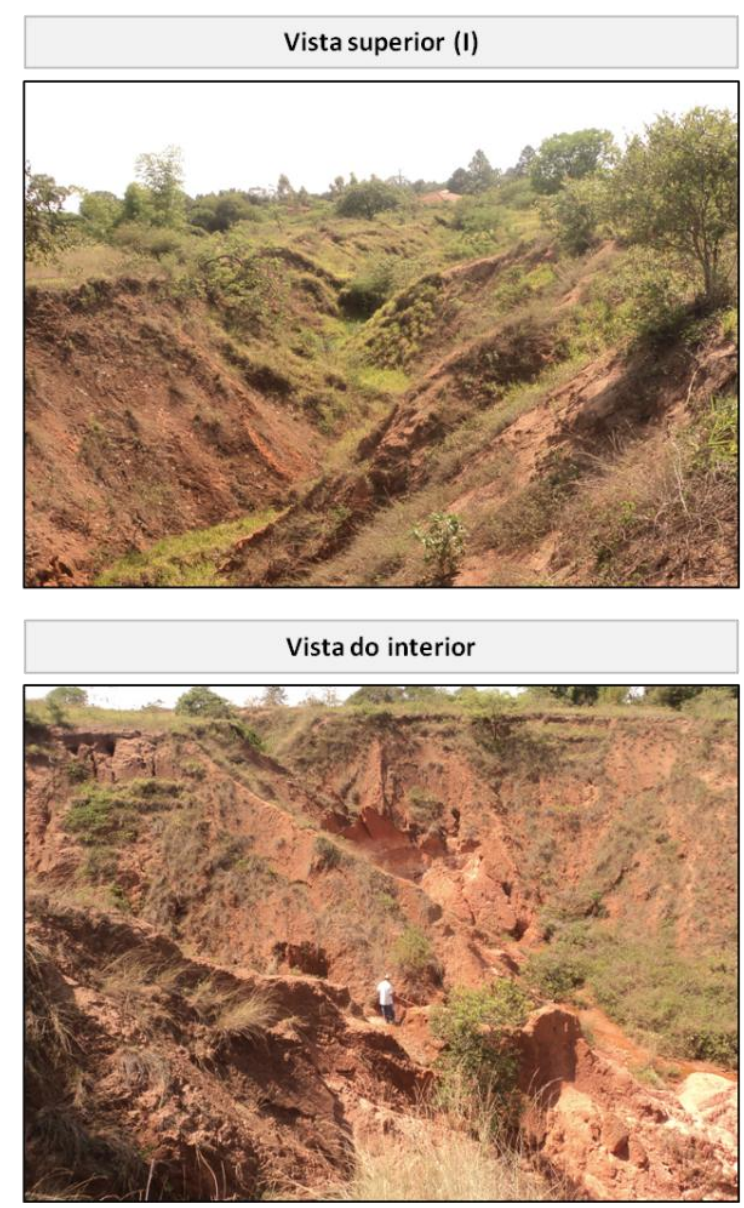
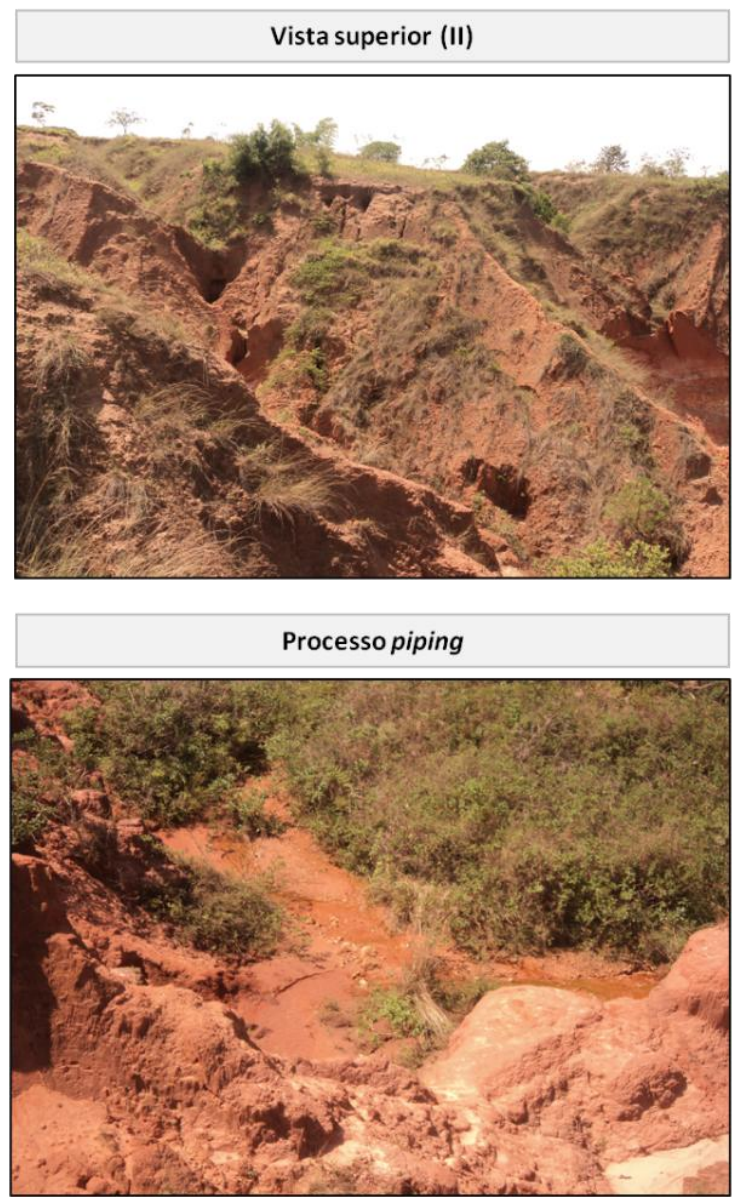

5.6.4.2 Avaliação das Cartas de Zoneamento de Áreas de Ocorrência de Erosões

A avaliação das áreas críticas foi realizada sobrepondo a Carta de Susceptibilidade à Carta de Zoneamento de Áreas de Ocorrência de Erosões (Índice Geral), e contabilizando as áreas coincidentes em termos percentuais, conforme o gráfico da Figura 85. Verifica-se que 68,72\% das áreas críticas da Carta de Zoneamento estão em conformidade com as classes mais susceptíveis a erosão, revelando um resultado satisfatório para o método aplicado, que considerou apenas parâmetros morfométricos e determinou de maneira empírica o limiar crítico. 
As áreas críticas também apresentam percentual de coincidência com as classes pouco e muito suscetível, no entanto, deve-se ponderar que os atributos e os métodos são diferentes, e que tais diferenças são aceitáveis, frente às inúmeras variáveis que interferem no desencadeamento das erosões.

Figura 85 - Percentual de áreas de ocorrência de erosões coincidentes com as classes de susceptibilidade.

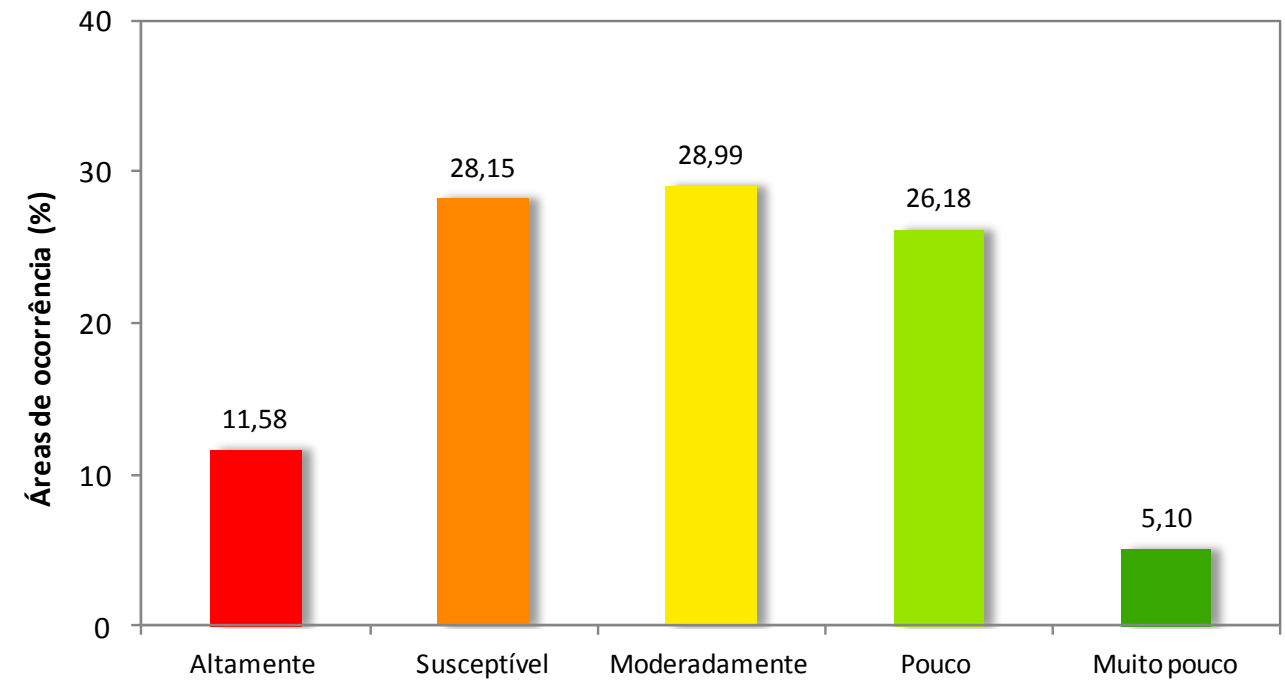

A Carta de Zoneamento sobreposta a Carta de Susceptibilidade pode ser observada na Figura 86. Observa-se a distribuição das áreas críticas sobre ou próximas às classes mais susceptíveis (altamente, susceptível e moderadamente), estas regiões estão concentradas nas porções do relevo onde existem encostas que propiciam o escoamento superficial concentrado. Todavia, verifica-se que nas classes menos susceptíveis quase não existe sobreposição destas áreas, mostrando mais uma vez a coerência entre estes mapas. 
Figura 86 - Carta de zoneamento de áreas de ocorrência de erosões sobreposta às classes de susceptibilidade.

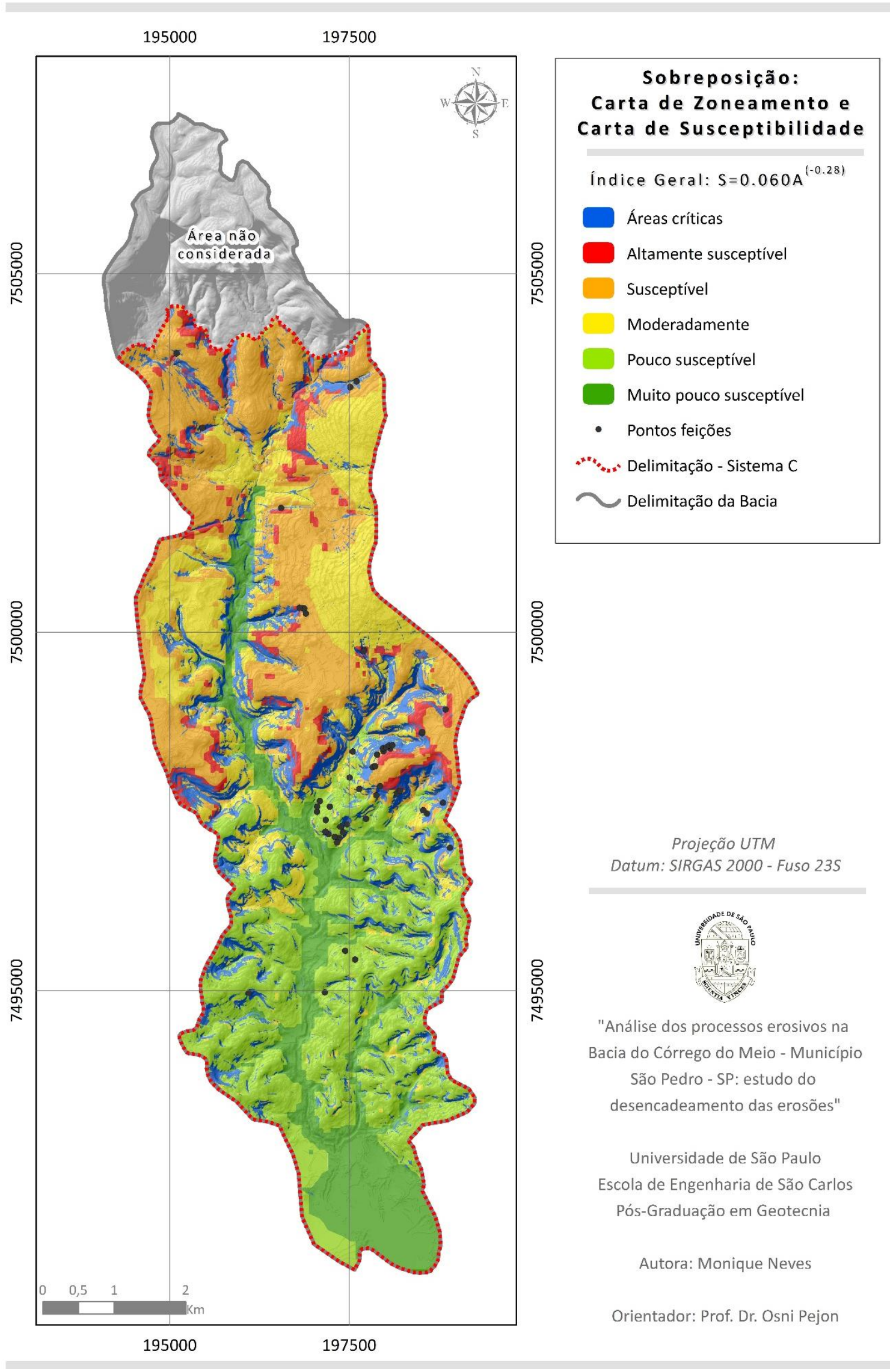


Em relação à Carta de Zoneamento de Áreas de Ocorrência de Erosões em Encosta o percentual de área coincidente com as classes altamente, suscetível e moderadamente foi ainda maior, 73,21\%, como pode ser verificado na Figura 87.

Observa-se que as características das classes mais susceptíveis, como terrenos com inclinação superior a 5\% que condicionam o escoamento superficial concentrado estão em conformidade com o valor da declividade crítica obtida para estes canais, que corresponde a $5,39 \%$.

Figura 87 - Percentual de áreas de ocorrência de erosões em encosta coincidentes com as classes de susceptibilidade.

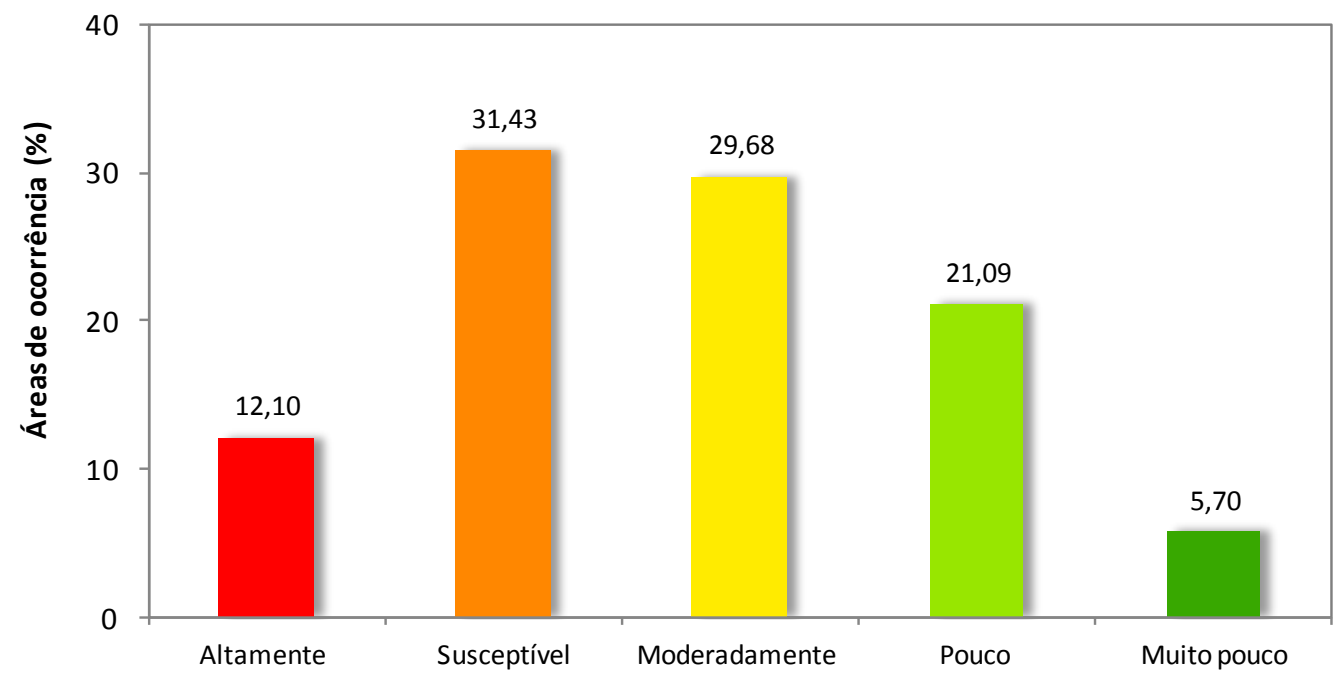

A Figura 88 apresenta a Carta de Zoneamento de Áreas Ocorrência de Erosão em Encosta sobreposta a Carta de Susceptibilidade. Verifica-se que as áreas críticas e mais susceptíveis ocorrem apenas nas encostas com vales fechados, e que quase não acontecem áreas críticas sobrepostas as classes menos susceptíveis. 
Figura 88 - Carta de zoneamento de áreas de ocorrência de erosões em encosta sobreposta às classes de susceptibilidade.

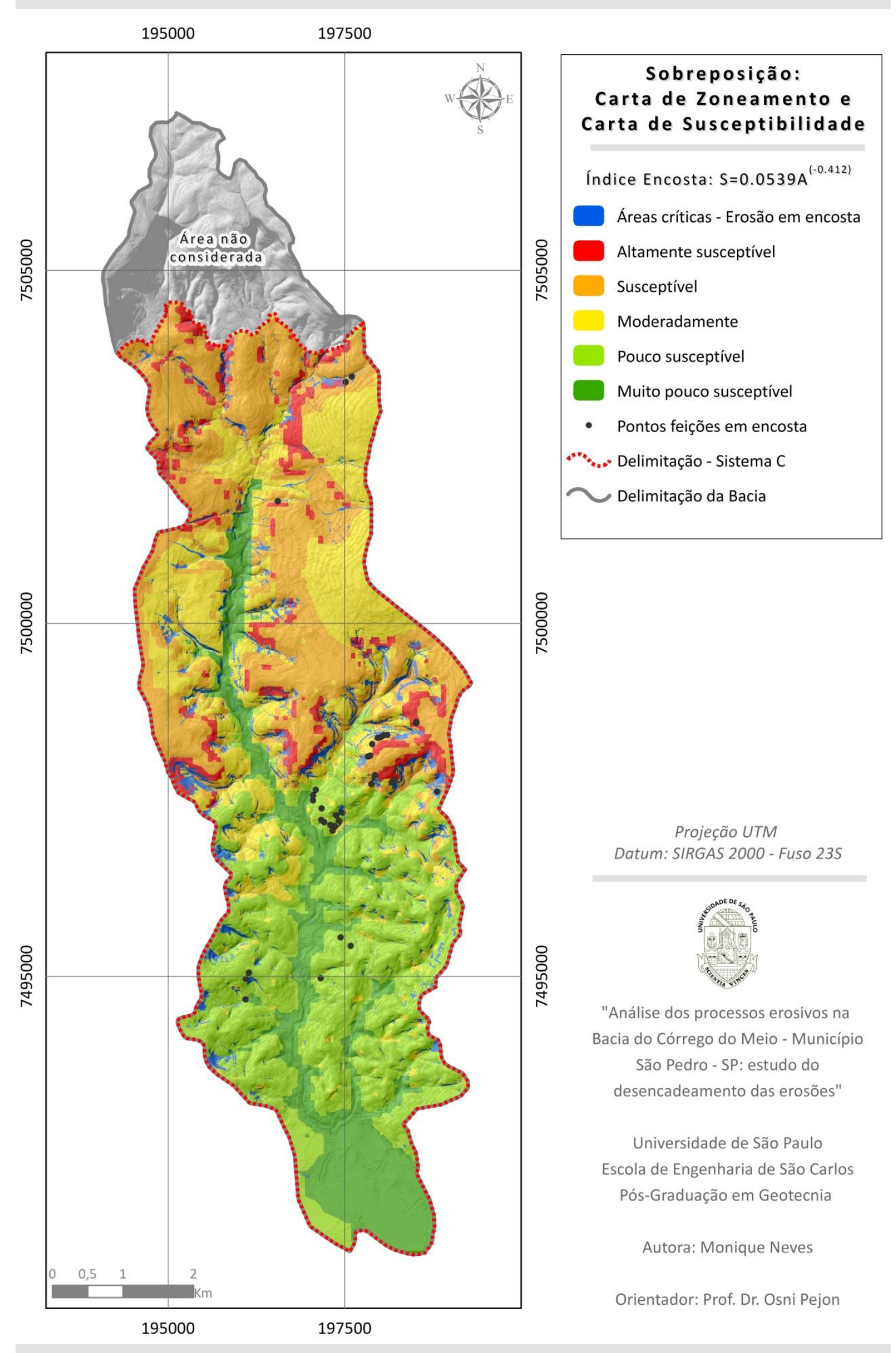


As áreas críticas de erosões em drenagem coincidentes correspondem a 73,52\% das classes altamente, susceptível e moderadamente, e assim como os canais em encostas, apresentam similaridade entre as características destas áreas (Figura 89).

Figura 89 - Percentual de áreas de ocorrência de erosões em drenagem coincidentes com as classes de susceptibilidade.

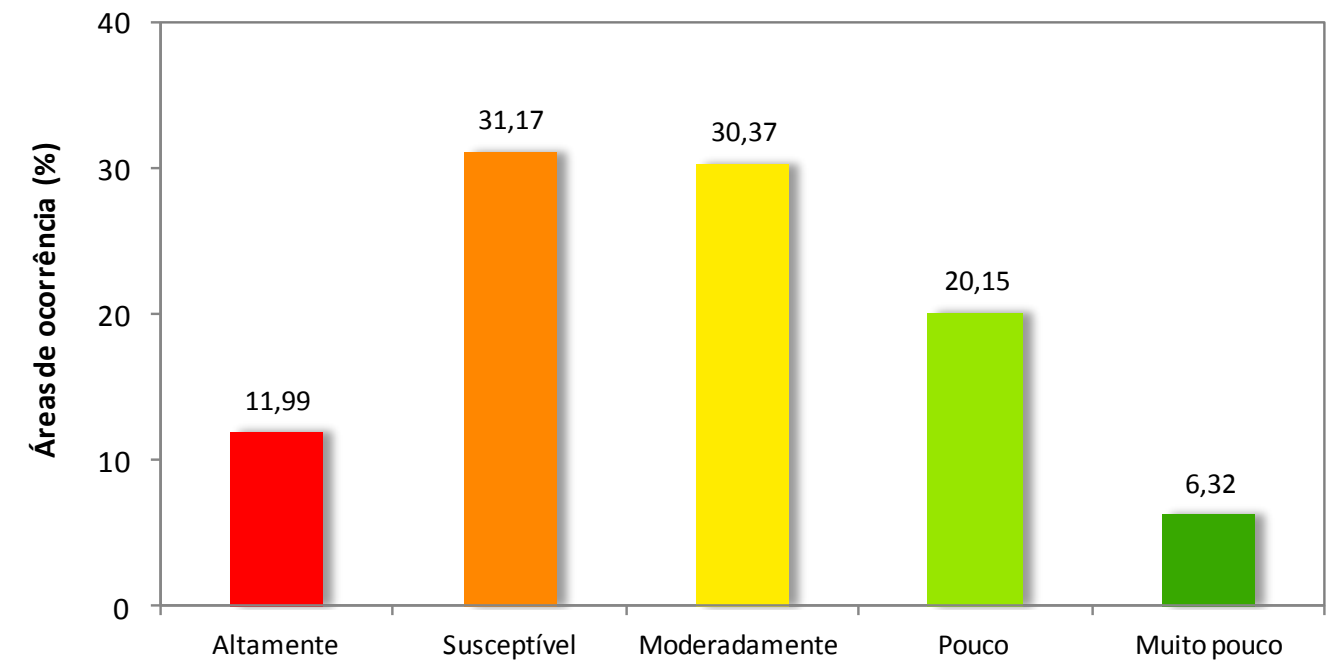

A Figura 90 apresenta a Carta de zoneamento e susceptibilidade sobrepostas. Observase que as áreas críticas de erosão em drenagem ocorrem nas margens dos canais, nas zonas com maior concentração de fluxo acumulado. Estas áreas coincidem principalmente com as características da classe susceptível, que são terrenos com maior inclinação, próximos às redes de drenagem. A declividade crítica obtida foi 7,48\% e está relativamente próxima à inclinação destes terrenos $(10 \%)$. 
Figura 90 - Carta de zoneamento de áreas de ocorrência de erosões em drenagem sobreposta às classes de susceptibilidade.

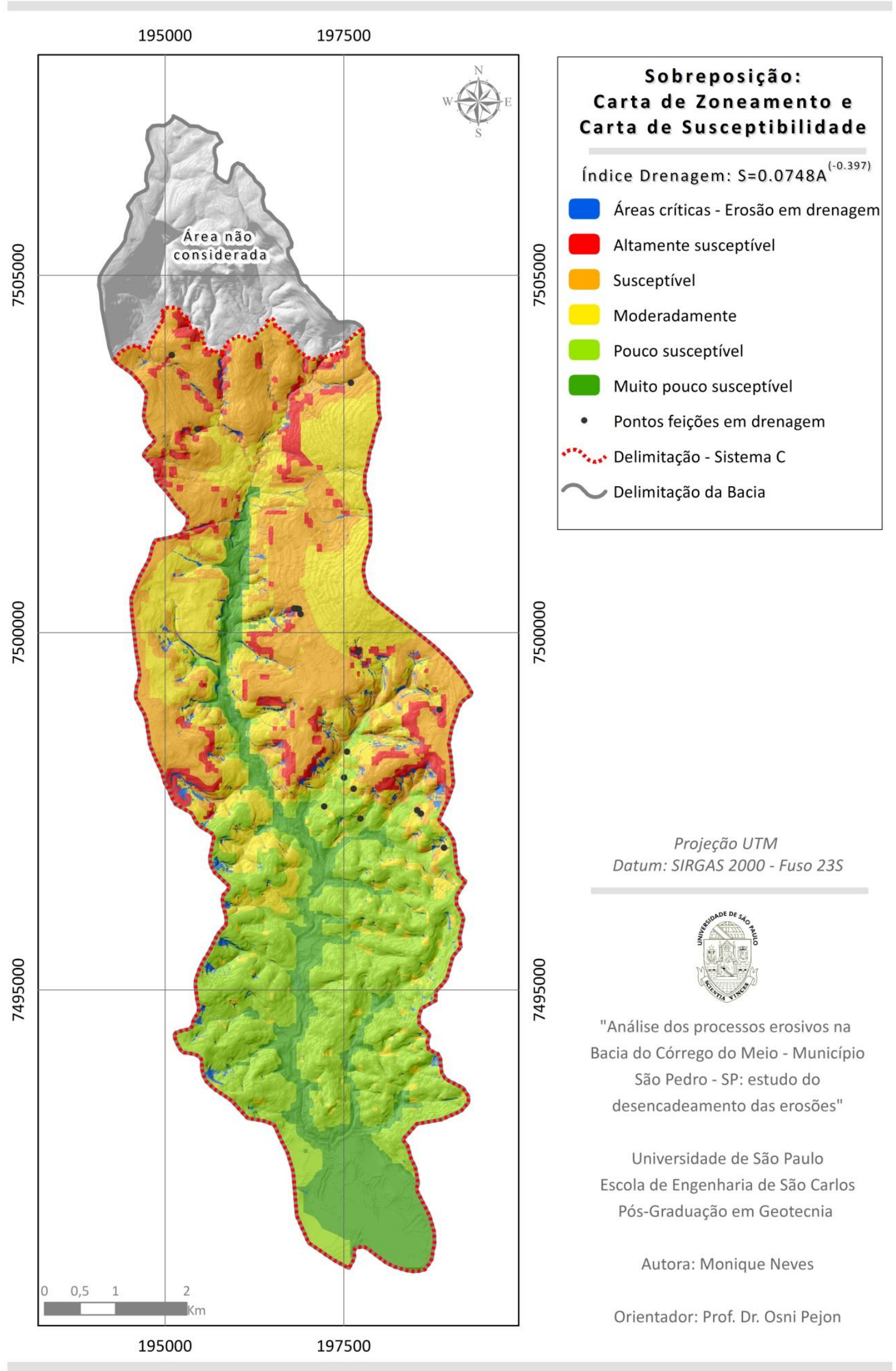


A confrontação das Cartas de Zoneamento de Áreas de Ocorrência de Erosões com a Carta de Susceptibilidade apresentou resultados satisfatórios, com mais de 60\% de áreas críticas coincidentes. Isto revela que a relação morfométrica utilizada neste trabalho, para determinação do limiar de desencadeamento das erosões, está coerente com outros produtos cartográficos que foram elaborados para avaliação dos processos erosivos.

Tais resultados demonstram que a Bacia do Córrego do Meio apresenta um percentual significativo de áreas críticas para ocorrência de processos erosivos, em função de características naturais, mas também evidenciou que alguns destes processos estão condicionados a intervenção antrópica.

A presença de áreas críticas de ocorrência de erosões em percentual significativo, em áreas classificadas como de susceptibilidade moderada à erosão por Gomes (2002), demonstra claramente que a intervenção antrópica pode conduzir ao surgimento de erosões em áreas que, mesmo não tendo alta predisposição para ocorrência de erosão, acabam apresentando problemas devido ao uso inadequado do solo. Este aspecto reforça a importância do estudo realizado, que pode alertar o planejador de maneira a evitar usos inadequados nas áreas críticas de ocorrência de erosão e assim impedir a degradação de área e minimizar os danos aos recursos naturais e ao meio ambiente de maneira geral.

Em termos de planejamento ambiental deve-se pensar na recuperação da Bacia do Córrego do Meio, principalmente das feições do tipo voçorocas, evitando a evolução destes processos e o surgimento de novos canais. A presença de erosões tanto em áreas urbanas como agrícolas, comprometem a dinâmica natural da área, ocasionando diversos problemas ambientais, como perda de solo e assoreamento dos recursos hídricos. Quando localizadas em áreas urbanas podem inviabilizar a expansão urbana, desvalorizando estes locais, e também favorecer o depósito de resíduos sólidos dentro das feições, acarretando a contaminação das águas subterrâneas. 



\section{Conclusões}

Este trabalho teve por objetivo estudar o desencadeamento das erosões lineares localizadas na Bacia do Córrego do Meio - Município de São Pedro - SP, com base na proposição dos índices $\mathrm{S} x \mathrm{~A}$, determinados com o auxílio de técnicas de geoprocessamento.

\subsection{Processamento automático}

A acurácia dos modelos digitais de elevação (MDE) elaborados para obtenção dos parâmetros área de contribuição (A) e declividade média (S) está diretamente relacionada com os parâmetros de entrada, que devem estar em escala compatível com o pixel de saída, e também digitalizados adequadamente, favorecendo a interpolação e representação das variações topográficas. Quanto à resolução, verificou-se que os modelos com resoluções maiores $(2 \times 2 \mathrm{~m})$ foram os mais indicados para aquisição dos parâmetros $\mathrm{A}$ e $\mathrm{S}$, e permitiram consequentemente a determinação de limiares críticos mais realistas. As áreas de contribuição obtidas a partir de modelos com resoluções menores $(30 \times 30 \mathrm{~m})$ foram muitos maiores, e por isso não correspondem às características da área.

Em relação aos métodos de aquisição dos mapas de fluxo acumulado (D8 e D-Infinity) observou-se que as áreas de contribuição definidas pelo algoritmo D-Infinity são mais condizentes com a topografia e com as características físicas da área, permitindo a determinação mais precisa dos parâmetros A e S. A escolha deste algoritmo e os resultados obtidos se refletiram no ajuste do limiar crítico de desencadeamento das erosões, pois favoreceram o ajuste matemático a partir dos pontos inferiores do gráfico $\mathrm{S} x \mathrm{~A}$, e também na obtenção das equações $\mathrm{S}=a \mathrm{~A}^{-b}$.

Desta forma, foi possível verificar que os diferentes algoritmos de fluxo acumulado interferem sobremaneira na posição e no ajuste do limiar crítico de desencadeamento das erosões. Por isso, ao realizar o processamento automático em SIG torna-se fundamental analisar os algoritmos disponíveis, com a finalidade de selecionar o mais indicado para representação dos parâmetros hidrológicos. Quanto ao software, o TauDEM apresentou como vantagem a disponibilidade dos dois algoritmos (D8 e D-Infinity) para processamento dos dados hidrológicos; a manipulação dentro da plataforma do ArcGIS 10.3; e sua disponibilidade como software open source. 


\section{2 Índices $\mathrm{S} x \mathrm{~A}$}

O índice obtido a partir da análise integrada de todas as feições da Bacia do Córrego do Meio (58 pontos) foi $\mathrm{S}=0,060 \mathrm{~A}^{-0,280}$. Neste caso a declividade crítica para o desencadeamento da erosão em uma área de contribuição de 1 ha $\left(10.000 \mathrm{~m}^{2}\right)$ seria de $6,04 \%$ $(0,0604 \mathrm{~m} / \mathrm{m})$. Este valor, relativamente baixo de declividade para o desencadeamento dos processos erosivos, evidencia que existem condições naturais que condicionam a ocorrência da erosão, como geologia e relevo. Estas características estão em conformidade com outros trabalhos, como Gomes (2002) e Araújo (2011), e mostram que os limiares críticos estão em conformidade com as características da área.

Apesar de ser um modelo de predição simples, pois consideram apenas fatores naturais, área de contribuição e declividade média, os resultados obtidos foram consistentes e auxiliam na compreensão da dinâmica do desencadeamento das erosões lineares em países de clima tropical. Estes dados são importantes, pois podem subsidiar ações de planejamento no âmbito geral, considerando os diferentes tipos de processos erosivos que podem surgir, desde sulcos a ravinas.

Os outros índices obtidos foram determinados a partir da classificação das feições, quanto à posição no relevo. Para os canais localizadas em encosta o índice foi $\mathrm{S}=0,0539 \mathrm{~A}^{-}$ 0,412 , enquanto que, para os canais em drenagem foi $\mathrm{S}=0,0748 \mathrm{~A}^{-0,397}$, os valores de declividade crítica para desencadeamento foram respectivamente 5,39\%, e 7,48\% (para uma área de contribuição de 1 ha). As diferenças entre os valores evidenciam que, as feições em encostas, do tipo sulcos e ravinas, requerem menor área de contribuição e declividade média para deflagração do processo, diferentemente das feições em drenagem, ravinas mais profundas e voçorocas, que necessitam de maiores áreas e declividades. Os resultados revelam que os mecanismos de desencadeamento são distintos, pois, são influenciados pela dinâmica do escoamento superficial, que pode ocasionar o surgimento de diferentes tipos de feições.

Os limiares críticos mais específicos, obtidos para profundidades menores que $0,5 \mathrm{~m}$ $\left(\mathrm{S}=0,0573 \mathrm{~A}^{-0,230}\right)$; entre 0,5 e $1 \mathrm{~m}\left(\mathrm{~S}=0,0631 \mathrm{~A}^{-0,491}\right)$; entre 1 e $1,5 \mathrm{~m} \quad\left(\mathrm{~S}=0,0767 \mathrm{~A}^{-0,663}\right)$; e maiores que $1,5 \mathrm{~m}\left(\mathrm{~S}=0,1196 \mathrm{~A}^{-0,383}\right)$, demonstram que a análise detalhada das erosões quanto ao seu tamanho proporciona melhor ajuste dos dados e permite a análise da área sob diferentes abordagens. 
A classificação das feições, seja quanto a posição no relevo ou profundidade dos canais, permitiu uma compreensão mais detalhada dos mecanismos de desencadeamento, e são importantes, pois favorecem o entendimento das outras variáveis que estão associadas ao surgimento destas feições, como práticas de manejo e uso do solo, que por sua vez, interferem ou aceleram a ocorrência destes processos. Desta maneira, as ações de planejamento podem ser aplicadas considerando as especificidades dos diferentes tipos de erosão.

\subsection{Cartas de Zoneamento de Áreas de Ocorrência de Erosões}

Ao implementar as equações $\mathrm{S}=a \mathrm{~A}^{-b}$ no $\mathrm{SIG}$ foi possível representar espacialmente os limiares críticos de desencadeamento das erosões, e desta forma, elaborar as Cartas de Zoneamento de Áreas de Ocorrência de Erosão, que indicam as áreas críticas e estáveis na Bacia do Córrego do Meio. As áreas críticas delimitadas mostraram conformidade com a maioria dos pontos de erosões identificados, no entanto, para os pontos que não estão próximos destas áreas, constatou-se que o surgimento destes canais está relacionado com outras variáveis, como uso do solo e intervenção antrópica.

Por fim, a comparação das Cartas de Zoneamento de Áreas de Ocorrência de Erosões com a Carta de Susceptibilidade revelou um percentual de coincidência entre as áreas críticas e susceptíveis acima de 60\%, evidenciando que a relação morfométrica, entre os parâmetros A e S, para representação dos limiares críticos está em conformidade com outros produtos cartográficos. Para as áreas não coincidentes, foi possível constatar que o surgimento das feições está condicionado a fatores antrópicos, e por isso, não apresentam relação direta com as características morfométricas.

A partir do desenvolvimento deste estudo, conclui-se que a Bacia do Córrego do Meio apresenta um percentual significativo de áreas críticas para ocorrência de processos erosivos, em função de características naturais. Além dos fatores naturais, constatou-se a forte influência dos aspectos antrópicos, principalmente na área urbana, que ocasionam o surgimento de processos erosivos mais complexos.

Desta maneira, torna-se fundamental a adoção de projetos de recuperação ambiental para a área, com o intuito de minimizar os danos aos recursos naturais e também as perdas econômicas e sociais, visto que algumas feições comprometem as áreas agrícolas e urbanas. As cartas de zoneamento elaboradas neste trabalho poderão auxiliar a execução destes projetos de duas maneiras, a primeira delas, evitando a ocupação inadequada nas áreas críticas 
de ocorrência das erosões, e a segunda orientando a adoção de medidas (ecológicas, agrícolas, mecânicas ou estruturais) visando à prevenção, controle, mitigação ou recuperação nas áreas afetadas pelos processos erosivos. 


\section{RECOMENDAÇõES}

Para desenvolvimento de outros trabalhos de mesma natureza, recomenda-se:

- Utilizar modelos digitais de elevação (MDE) hidrologicamente consistentes e com maior resolução para obtenção dos dados área de contribuição e declividade média;

- Aplicação de algoritmos de fluxo distribuído, como o D-Infinity, para elaboração dos mapas de área de contribuição;

- Realização de etapas de campo, para levantamento de informações in loco, para auxiliar a classificação das feições erosivas, com a finalidade de melhor o ajuste entre os parâmetros A e S;

- Propor índices uma classificação das feições erosivas, com base em outros fatores condicionantes como uso do solo (estágio inicial da feição) e geologia;

- Consolidar os modelos de predição para as condições dos países tropicais, com base nas equações propostas por Dietrich et al. (1992) a partir de parâmetros hidrológicos e geotécnicos. 



\section{REFERÊNCIAS BibLIOGRÁFICAS}

ABERA, W.; ANTONELLO, A.; FRANCESCHI, S.; FORMETTA, G.; RIGON, R. The uDig Spatial Toolbox for hydro-geomorphic analysis. Geomorphological techniques, cap. 2, p. 1-19, 2014.

ALMOROX, A. J.; BERMUDÉZ, F. L.; RAFAELLI, S. La degradacion de lós suelos por erosion hídrica: métodos de estimacion. Murcia: Universidade de Murcia, 2010. 384p.

ARAUJO, T. P. de. Estudo do desencadeamento das erosões lineares concentradas em uma área do município de São Pedro/ SP. 2011. 181 p. Dissertação - Escola de Engenharia de São Carlos, Universidade de São Paulo, São Carlos, 2011.

AUGUSTO FILHO, O. Análise de métodos de interpolação de modelo digital de terreno e aplicação em SIG de gestão de riscos geotécnicos e ambientais em oleodutos. In: Congresso Brasileiro de Geologia de Engenharia Ambiental, 13., 2011, São Paulo. Anais... São Paulo: 2011, p. 1 - 9.

AUGUSTO FILHO, O. Sistema de informações geográficas aplicados à engenharia ambiental. In: CUNHA, D. G. F.; CALIJURI, M. C. Engenharia Ambiental: conceitos, tecnologia e gestão. Rio de Janeiro: Elsevier, 2013. p. 643 - 667.

BARROW, C. J. Land Degradation. In: BARROW, C. J. Erosive soil degradation. Reino Unido: Cambridge University, 1991. p. 199-219.

BEGIM, Z. B.; SCHUMM, S. A. Instability of alluvial valley floors: a method for its assessment. Transactions of the Asae, v.22, p. 347 - 350, 1979.

BERTONI, J.; LOMBARDI NETO, F. Conservação do Solo. São Paulo: Ícone, 1990. 355 p.

BOSQUILIA, R. W. D. Geotecnologias aplicadas ao mapeamento de drenagens e nascentes. 2014. 136p. Dissertação, Universidade de São Paulo, Piracicaba. 2014.

BRASIL. Lei $\mathbf{N}^{\circ} \mathbf{9 . 4 3 3}$ de 8 de janeiro de 1997. Disponível em: <http://www.planalto.gov.br/ccivil_03/leis/L9433.htm>. Acesso em: 26 jan. 2016.

CALIJURI, M. do C.; CUNHA, D. G. F.; POVINELLI, J. Sustentabilidade: um desafio da gestão dos recursos hídricos. São Carlos: EESC - USP, 2010. 80 p.

CÂMARA, G.; MEDEIROS, J. S. Geoprocessamento em projetos ambientais. São José dos Campos: INPE, 1998, 190 p.

CBPE - Companhia Brasileira de Projetos e Empreendimentos. Planos das bacias hidrográficas dos Rios Piracicaba, Capivari e Jundiaí 2010 a 2020 - Relatório Síntese. Cobrape: Neoband Soluções Gráficas, São Paulo, 2011, 128p.

CELESTINO, T. B.; DINIZ, N. C. Informática. In: OLIVEIRA, A. M.; BRITO, S. N. A. Geologia de Engenharia. São Paulo: ABGE, 1998, Cap 14. p. 227-241. 
CEPAGRI - Centro de Pesquisas Metereológicas e Climáticas Aplicadas a Agricultura. Disponível em: < http://www.cpa.unicamp.br/outrasinformacoes/clima_muni_566.html>.Acesso em: mar. 2016.

CHAVES, M. A. Modelos digitais de elevação hidrologicamente consistentes para a Bacia Amazônica. 2002. Tese. Universidade Federal de Viçosa, Viçosa: UFV, 2002.

COSTA-CABRAL, M.; BURGES, S.J. Digital elevation model networks (DEMON): a model of flow over hillslopes for computation of contributing and dispersal areas. Water Resources Research, v. 30, p. 1681-1692, 1994.

CROSTA, A. P. Processamento digital de imagens de sensoriamento remoto. Campinas: IG/UNICAMP, 1992. 170p.

DAEE - Departamento de água e energia elétrica. Banco de Dados Hidrológicos. Disponível em

http://www.hidrologia.daee.sp.gov.br/Default.aspx?dadosorigem=Fluviom\%C3\%A9tric os\&ugrhi=UGRHI\&cidadeugrhi=PIRACICABA\%2FCAPIVARI\%2FJUNDIAI\&prefix oposto=4D-007> . Acesso em: mar. 2016.

DAEE - Departamento de água e energia elétrica. Mapa de águas subterrâneas do estado de São Paulo. 1:250.000. DAEE/IG/IPT/CPRM: 2007.

DANTAS-FERREIRA, M. Análise da evolução dos processos erosivos acelerados em áreas urbanas e das técnicas de controle e recuperação - Córrego do Tucum (São Pedro/SP). 2004. 171 f. Dissertação, Escola de Engenharia de São Carlos, Universidade de São Paulo, São Carlos, 2004.

DANTAS-FERREIRA, M. Proposta de índice para processos erosivos acelerados a partir de levantamento e diagnóstico geológico-geotécnico de áreas degradadas. 2008. 447 f. Tese, Escola de Engenharia de São Carlos, Universidade de São Paulo, São Carlos, 2008.

DANTAS-FERREIRA, M.; PEJON, O. J. Análise temporal das feições erosivas lineares: São Pedro. In: Simpósio Brasileiro de Cartografia Geotécnica e Geoambiental, 5, 2004. Anais... São Carlos, 2004. p. 131 - 139.

DIETRICH, W. E.; WILSON, C. J.; MONTGOMERY, D. R.; BAUER, J. M. R. Erosion thresholds and land surface morphology. Geology, v. 20, p. 675 - 679, 1992.

DINIZ, N. C. Cartografia geotécnica por classificação de unidades de terreno e avaliação de suscetibilidade e aptidão. Revista Brasileira de Geologia de Engenharia e Ambiental, v. 2, n. 1, p. 29 - 77, 2012.

ESRI. ArcGIS: Tools. Disponível em: http://desktop.arcgis.com/en/arcmap/10.3/main/tools/a-quick-tour-of-geoprocessingtool-references.htm>. Acesso em: marc. 2017.

FACINCANI, E. M.; CAVALHEIRO, F. Boçorocas: aspectos da reabilitação por revegetação na região de São Pedro, SP. Revista Geociências, v.14, n. 2, p. 269-275, 1995. 
FAIRFIELD, J.; LEYMARIE, P. Drainage network from a digital elevation model. Water Resources Research. v.25, p. 709-717, 1991.

FARINASSO M.; CARVALHO JUNIOR, O. A.; GUIMARÃES, R. F.; GOMES, R. A. T.; RAMOS, V. M. Avaliação qualitativa do potencial de erosão laminar em grandes áreas por meio da EUPS - Equação universal de perdas de solos utilizando novas metodologias em SIG para os cálculos dos seus fatores na região do Alto Parnaíba - PIMA. Revista Brasileira de Geomorfologia, v. 2, p. 73-85, 2006.

FENDRICH, R.; OBLADEN, N. L.; AISSE, M. M.; GARCIAS, C. M. Drenagem e controle da erosão urbana. Curitiba: Champagnat, 1997. 486 p.

FITZ, P. R. Geoprocessamento sem Complicação. São Paulo: Oficina de Texto, 2008, 160 p.

FREEMAN, T. G. Calculating catchement area with divergent flow based on a regular grid. Computers \& Geosciences.v. 17, n. 13, p. 413-422, 1991.

FUREGATTI, S. A. Avaliação da variabilidade das características geotécnicas relacionadas aos processos erosivos com ensaios in situ. 2012. 467 p. Tese, Escola de Engenharia de São Carlos, Universidade de São Paulo, São Carlos, 2012.

GARCIA, G. J. Sensoriamento remote: princípios e interpretação de imagens. Nobel: São Paulo, 1982. 357 p.

GOMES, D. M. Mapeamento geológico-geotécnico para análise de feições erosivas concentradas na Bacia do Córrego Ribeirão do Meio, região de São Pedro/SP, na escala 1:20.000. 2002. 242 f. Dissertação, Escola de Engenharia de São Carlos, Universidade de São Paulo, São Carlos, 2002.

GRANDO, A. Monitoramento e modelagem hidrossedimentológica em uma microbacia hidrográfica experimental. 2011. 175 p. Dissertação, Universidade Federal de Santa Catarina, Florianópolis, 2011.

GUERRA, A. J. T. Processos erosivos nas encostas. In: GUERRA; A. J. T.; CUNHA, S. B. Geomorfologia: uma atualização de bases e conceitos. Rio de Janeiro: Bertrand Brasil, 1998, p. 149 - 199.

GUIMARÃES, C. N. Mapeamento geotécnico da Bacia Córrego da Barra, aplicação do penetrômetro de impacto em estudos de processos erosivos São Pedro - SP - Escala 1:10.000. 2008. 104 f. Dissertação, Escola de Engenharia de São Carlos, Universidade de São Paulo, São Carlos, 2008.

GUTIÉRREZ, A. G.; SCHNABEL, S.; CONTADOR, F. L. Gully erosion, land use and topographical thresholds during the last 60 years in a small rangeland catchment in $\mathrm{Sw}$ Spain. Land Dregadation \& Development, v. 20, p. 535 - 550, 2009.

HUTCHINSON, M. F. A new procedure for gridding elevation and stream line data with automatic removal of spurious pits. Journal of Hydrology, n.106. p. 211-232, 1989. 
HUTCHINSON, M. F. Calculation of hydrologically sound digital elevation models. In: Third International Symposium on Spatial Data Handling at Sydney, Australia, 1988.

IBGE - Instituto Brasileiro de Geografia e Estatística. Disponível em: $<$ http://www.cidades.ibge.gov.br/xtras/perfil.php?lang=\&codmun=3550407>. Acessado em: mar 2016.

IBGE - Instituto Brasileiro de Geografia e Estatística. Mapa de Biomas do Brasil 1:500.000. IBGE/MMA: 2004.

IF - Instituto Florestal do Estado de São Paulo. Mapa Florestal dos municípios do estão de São Paulo: São Pedro - 1:200.000. IF/ESALQ/UNICAMP: 2001.

IG - Instituto Geológico do Estado de São Paulo. Mapeamento do uso e cobertura do solo da UGRHI 5 (PCJ) - 1:25.000. CPLA/IG/IGC: 2013.

INFANTI JR, N.; FORNASARI FILHO, N. Processos de Dinâmica Superficial. In: OLIVEIRA, A. M. dos S.; BRITO, S. N. A. de. Geologia de Engenharia. São Paulo: ABGE, 1998. p. 131-152.

IPT - Instituto de Pesquisas Tecnológicas. Mapa Geomorfológico do Estado de São Paulo 1:500.000. USP/IPT: 1981.

JORGE, F. N.; UEHARA, K. Águas de superfície. In: OLIVEIRA, A. M. S.; BRITO, S. N. Geologia de Engenharia. São Paulo: ABGE, 1998. p. 101 - 109.

KUWAJIWA, J. I. Análise do modelo SWAT como ferramenta de prevenção e estimação de assoreamento no reservatório do Lobo (Itaripina/Brotas/SP). Dissertação, Escola de Engenharia de São Carlos, Universidade de São Paulo, São Carlos, 2012.

LAL, R. Soil erosion in the tropics: principles and management. New York: Mcgraw-Hill, 1990, 580p.

LAL, R. Soil erosion research methods. Florida: St. Lucie Press, 1994. 340 p.

LEA, N. L. An aspect driven kinematic routing algorithm. In: Parsons, A.J.; Abrahams, A. D. Overland Flow: Hydraulics and Erosion Mechanics, 1992, p. 374-389.

LOLLO, J. A. O uso da técnica de avaliação do terreno no processo de elaboração de mapeamento geotécnico: sistematização e aplicação para quadrícula de Campinas (SP). 1995. 246 p. Tese, Escola de Engenharia de São Carlos - Universidade de São Paulo, São Carlos, 1995.

MACHADO, C. J. S. A gestão francesa de recursos hídricos: descrição e análise dos princípios jurídicos. Revista Brasileira de Recursos Hídricos, v. 8, n. 4, p. 37-47, 2003.

MAGRI, R. A. F. Análise da suscetibilidade à erosão da região do Médio Rio Grande (MG). 2013. 202 f. Dissertação, Escola de Engenharia de São Carlos, Universidade de São Paulo, São Carlos, 2013. 
MAPEIA SÃO PAULO - Sistema de Visualização de Dados. Disponível em: <http://www.mapeiasp.sp.gov.br/Login>. Acesso em: out.2016.

MENÉNDEZ-DUARTE, R.; MARQUÍNEZ, J.; FERNÁNDEZ-MENÉNDEZ, S.; SANTOS, R. Incised channels and gully erosion in Northern Iberian Peninsula: Controls and geomorphic setting. Catena, v. 71, p. 267 - 278, 2007.

MITCHELL, A. Getting started with ArcGIS. USA: ESRI, 1999, 253 p.

MONTGOMERY, D.; DIETRICH, W. Landscape dissection and drainage area-slope thresholds. In: Kirkby, M. J (Ed). Process models and theoretical geomorphology. Chichester: Wiley, 1994, p. 221-246.

MORGAN, R. P. C. Soil erosion and conservation. Inglaterra: Longman Group, 1986. 298 p.

NAZARI SAMANI, A.; AHMADI, H.; JAFARI, M.; BOGGS, G.; GHODDOUSI, J.; MALEKIAN, A. Geomorphic threshold conditions for gully erosion in Southwestern Iran (Boushehr-Samal Wastershed). Journal of Asian Earth Sciences, v. 35, p. 180189, 2009.

NETTO, M. M.; SOBREIRA, F. G. Os processos erosivos lineares da bacia hidrográfica do Ribeirão Carioca, Itabirito/MG e seus condicionantes principais: observações preliminares. Revista Brasileira de Geomorfologia, n. 2, p. 13 - 21, 2006.

NOVO, E. M. L. M. Sensoriamento remoto: princípios e aplicações. São Paulo: Edgard Blücher, 1992, 308 p.

O'CALLAGHAN, J. F.; MARK, D. M. The extraction of drainage network from digital elevation data. Computer vision, graphics image process, v. 28, p. 323-344, 1984.

O'LOUGHLIN, E. M. Prediction of surface saturation zones in natural catchments by topographic analysis. Water resources research, v. 22, n. 5, p. 794 - 804, 1986.

OlIVEIRA, A. H.; SILVA, M. A.; SILVA, M. L.; CURI, N.; KLINKE NETO, G.; FREITAS, D. A. F. Development of topographic factor modeling application in soil erosion models. In: Soriano, M. C. Soil process and current trends is quality assessment. Croatia: InTech, 2013, p. 111 - 138.

OLIVEIRA; J. B.; PRADO, H. Carta Pedológica Semi-Detalhada do Estado de São Paulo - 1:100.000. Folha Piracicaba - SF-23-Y-A-IV. IAC/IFC: 1989.

PATTON, P. C.; SCHUMM, S. A. Gully erosion, northwestern Colorado: a threshold phenomeno. Geology, p. 88-90, 1975.

PEJON, O. J. Mapeamento geotécnico regional da folha de piracicaba - SP (Escala 1:100.000: estudo de aspectos metodológicos, de caracterização e de apresentação de atributos. 1992. Tese, Escola de Engenharia de São Carlos, Universidade de São Paulo, São Carlos, 1992.

PEJON, O. J.; ZUQUETTE, L. V. Mapeamento geotécnico regional na escala 1:100.000 considerações metodológicas. Revista IG. p. 23 - 29, 1995. 
PMSP - Prefeitura Municipal de São Pedro. Plano Municipal de Saneamento Básico de São Pedro - Sistema de Abastecimento de água. PROESPLAN: Engenharia, São Pedro, v. $1,2013,229 \mathrm{p}$.

PMSP - Prefeitura Municipal de São Pedro. Site oficial da Prefeitura de São Pedro /SP. In: <http://www.saopedro.sp.gov.br/sao-pedro>. Acessado em: mar.2016.

POESEN, J.; NACHTERGAELE, J.; VERSTRAETEN, G.; VALENTIN, C. Gully erosion and environmental change: importance and research needs. Catena, v. 50, p. 91-133, 2003.

PORTO, M. F. A.; PORTO, R. L. L. Gestão de bacias hidrográficas. Revista Estudos Avançados. v. 22, p. 43- 60, 2008.

QUINN, R.; BEVEN, K.; CHEVALLIER, P.; PLANCHON, O. The prediction of hillslope flow paths for distributed hydrological modeling using digital terrain models. Hydrological processes. v. 5, p. 59-79, 1991.

RAMOS, V. M.; GUIMARÃES, R. F.; REDIVO, A. L.; CARVALHO JUNIOR, O. A.; FERNANDESE, N. F.; GOMES, R. A. T. Avaliação de metodologias de determinação do cálculo de áreas de contribuição. Revista Brasileira de Geomorfologia, n. 4, p. 4149, 2003.

RANIERI, S. B. L. Avaliação de métodos e escalas de trabalho para determinação de risco a erosão em bacias hidrográficas utilizando sistema de informação geográfica (SIG). 1996. 128 p. Dissertação, Escola de Engenharia de São Carlos, Universidade de São Paulo, São Carlos, 1996.

RODRIGUES, M. Introdução ao geoprocessamento. In: Simpósio Brasileiro de Geoprocessamento, 1990. São Paulo: 1990, p. 1 - 27.

ROTTA, C. M. S.; ZUQUETTE, L. V. Processos erosivos. In: ZUQUETTE, L. Geotecnia ambiental. Rio de Janeiro: Elsevier, 2015, p. 115-152.

RUHE, R.V. Geomorphology: geomorphic processes and surficial geology. Boston: Houghton Mifflin Company, 1975. 246p.

SAATY, T. L. The analytic hierarchy process. New York: McGraw Hill. 1980.

SALOMÃO, F. X. T.; CANIL, K.; RODRIGUES, S. P. Exemplo de aplicação da geologia de engenharia no controle preventivo e corretivo dos processos erosivos. Revista Brasileira de Geologia de Engenharia e Ambiental, v. 2, n. 2, p. 39 - 56, 2012.

SALOMÃO, F. X. T.; IWASA, O. Y. Erosão e a ocupação rural e urbana. In: BITAR, O. Y (Coord). Curso de geologia aplicada ao meio ambiente. São Paulo: ABGE IPT, 1995, p. 5-148, 1995.

SANTORO, J. Erosão Continental. In: TOMINAGA, L. K.; SANTORO, J.; AMARAL, R. do. Desastres naturais: conhecer para prevenir. São Paulo: Instituto Geólogico, 2009 , p. $53-70$. 
SANTOS, I. Modelagem geobiohidrológica como ferramenta no planejamento ambiental: estudo da bacia hidrográfica do Rio Pequeno, São José dos Pinhais PR. 2001. 93 f. Dissertação, Universidade Federal do Paraná, Curitiba, 2001.

SILVA, A. F. Mapeamento geotécnico e análise dos processos erosivos na Bacia do Córrego Tuncum, São Pedro - SP, Escala 1:10.000. 2003. 131 f. Dissertação, Escola de Engenharia de São Carlos, Universidade de São Paulo, São Carlos, 2003.

SILVA, S. F. Avaliação das alterações ambientais na sub-bacia hidrográfica do Ribeirão do Piçarrão, Campinas - SP. 2000. 138 f. Dissertação, Escola de Engenharia de São Carlos, Universidade de São Paulo, São Carlos, 2000.

SOBREIRA, F. G. Cartas geotécnicas em áreas sujeitas a escorregamentos. In: Simpósio brasileiro de cartografia geotécnica e geoambiental, 5, 2004, São Carlos: 2004, p. $151-153$.

SOBREIRA, F. G.; SOUZA, L. A. Cartografia geotécnica aplicada ao planejamento urbano. Revista Brasileira de Geologia de Engenharia Ambiental, v. 2, n. 1, p. 79-97, 2012.

SORENSEN, R.; SEIBERT, J. Effects of DEM resolution on the calculation of topographical indices: TWI and its components. Jornal of hydrology, v. 347, p. 74-89, 2007.

SOUZA, N. M.; CELESTINO, V. R. R. Contribuição à análise de decisões em cartografia geotécnica com uso de geoprocessamento: sensoriamento remoto e sistema de informação geográfica. In: Simpósio brasileiro de cartografia geotécnica e geoambiental, 2004. São Carlos: 2004, p. 509 - 515.

SOUZA, N. M.; GANDOLFI, N. Geoprocessamento para a cartografia geotécnica. In: Congresso Brasileiro de Geologia de Engenharia, 7, 1993. Poços de Caldas: ABGE, 1993, p. 25 - 31.

STABILE, R. A. Limites topográficos de feições erosivas lineares em Piratinga (SP). 2013. 103p. Dissertação. Faculdade de Filosofia, Letras e Ciências Humanas da Universidade de São Paulo, São Paulo, 2013.

TARBOTON, D. G. A new method for the determination of flow directions and upslope areas in grid digital elevation models. Water Resources Research, v. 33, n. 2, p. 309-319, 1997.

TAUDEM. Hydrology Research Group. Disponível em: < http://hydrology.usu.edu/taudem/taudem5/help53/DInfinityContributingArea.html>. Acesso em: Mar. 2017.

TORRI, D.; POESEN, J. A review of topographic threshold conditions for gully head development in different environments. Earth-Science Reviews, v. 130, p. 73-85, 2014.

TUNDISI, J. G. Novas perspectivas para a gestão de recursos hídricos. Revista USP, n. 70, p.24-35, 2006.

TURCOTTE, R.; FORTIN, J. P.; ROUSSEAU, A. N.; MASSICOTE, S.; VILLENEUVE, J.P. Determination of the drainage structure of a watershed using digital elevation model and a digital river and lake network. Journal of hydrology, n. 240, p. 225-242, 2001. 
VALERIANO, M. M. Dados topográficos. In: Florenzano, T. G. Geomorfologia, conceitos e tecnologias atuais. São Paulo: Oficina de texto, 2008, p. 72-104.

VANDAELE, K.; POESEN, J.; MARQUES SILVA, J. R.; GOVERS, F.; DESMET, P. Assessment of factors controlling ephemeral gully erosion in Southern Portugal and Central Belgium using aerial photographs. Z. Geomorph. N. F., v. 41, p. 237-287, 1995.

VANDAELE, K.; POESEN, J.; GOVERS, G.; WESEMAEL, B. Geomorphic threshold conditions for ephemeral gully incision. Geomomorphology, v. 16, p. 161 - 173, 1996.

VANDEKERCKHOVE, L.; POESEN, J.; OOSTWOUD WIJDENES, D., FIGUEIREDO, T. Topographical thresholds for ephemeral gully initiation in intensively cultivated areas of the Mediterranean. Catena, v. 33, p. 217-292, 1998.

VANDEKERCKHOVE, L.; POESEN, J.; WIJDENES OOSTWOUD, D.; NACHTERGAELE, J.; KOSMAS, C.; ROXO, M. J.; FIGUEIREDO, T. Thresholds for gully initiation and sedimentation in Mediterranean Europe. Earth Surface Processes and Landforms. v. 25, p. 1201-1220, 2000.

VANWALLEGHEM, T.; POESEN, J.; NACHTERGAELE, J.; VERSTRAETEN, G. Characteristics, controlling factors and importance of deep gullies under cropland on loess-derived soils. Geomorphology, v. 69, p. 76-91, 2005.

VESTENA, L. R.; KOBIYAMA, M. Indentificação e mapeamento dos processos erosivos na bacia hidrográfica do Rio Caeté, no município de Alfredo Wagner/SC. Revista Brasileira de Geomorfologia. v. 15, n. 1, p. 22-33, 2014.

VILAR, O. M. Modelo matemático para a erosão dos solos. Revista Brasileira de Ciência do Solo. v. 13, p. 381 - 385, 1989.

VILAR, O. M.; PRANDI, E. C. Erosão dos Solos. In: CINTRA, J. C.A; ALBIERO, J. H. (Org.). Solos do interior de São Paulo. São Paulo: ABMS, 1993, v. 1, p. 177-206.

WALSH, L. Digital Topography: Should you choose a TIN or raster interpolation of the landscape?. The University of Maryland, Geology Department.2017. Disponível em: <http://serc.carleton.edu/vignettes/collection/42681.html>. Acesso em: Fev. 2017.

WISCHMEIER, W. H.; SMITH, D. D. Rainfall energy and its relationships to soil loss. Transactions of the American Geophysical Union. v. 39, n. 2, p. 285-291, 1958.

WISCHMEIER, W. H.; SMITH, D. D. Predicting rainfall erosion losses - A guide to conservation planning. U. S. Departamento of Agriculture. Agriculture Handbook, n. $537,1978$.

XAVIER DA SILVA, J. O que é geoprocessamento?. Revista do CREA - RJ, p. 42-44, 2009.

XUJIONGXIN, J. Beggang erosion: the influencing factors. Catena, v. 27, p. 249-263, 1996.

YASSUDA, E. R. Gestão de recursos hídricos: fundamentos e aspectos institucionais.

Revista administração pública, v. 27, n. 2, p. 5-18, 1993. 
ZACHAR, D. Soil Erosion. New York: Elsevier, 1982. 548 p.

ZHANG, W.; MONTGOMERY, D. Digital elevation model grid size, landscape representation and hydrological simulations. Water resources research, v. 30, n. 4, p. 1019-1028, 1994.

ZUQUETTE, L. V. Análise crítica da cartografia geotécnica e proposta metodológica para condições brasileiras. 1987. Tese, Escola de Engenharia de São Carlos, Universidade de São Paulo, São Carlos, 1987.

ZUQUETTE, L. V. Importância do mapeamento geotécnico no uso e ocupação do meio físico: fundamentos e guia de elaboração. Tese de Livre Docência, Escola de Engenharia de São Carlos, Universidade de São Paulo, São Carlos, 1993.

ZUQUETTE, L. V.; CARVALHO, A. R.; YAMANOUTH, G. R. B. Feicões erosivas na bacia do córrego Espraido, São Pedro (SP), seus tipos e evolução entre 1972-2002. Revista Brasileira de Geociências, v. 37, n. 2, p. 414-425, 2007.

ZUQUETTE, L. V.; GANDOLFI, N. Cartografia geotécnica. São Paulo: Oficina de Texto, 2004, 190 p.

ZUQUETTE, L. V.; PEJON, O. J.; SINELLI, O.; GANDOLFI, N. Mapeamento geotécnico da cidade de Franca (SP), Brasil - Escala 1:25.000: Carta de riscos à erosão. Revista Geociências. v. 14, n. 2, p. 41-58, 1995. 

ANEXO A

\begin{tabular}{|c|c|c|c|c|c|c|c|c|c|c|c|c|c|c|c|c|}
\hline$X$ & $Y$ & Ponto & Unidade & $\%$ Argila & $\%$ Silte & $\%$ Areia & $\rho s$ & $\rho d$ & $e_{0}$ & $V B$ & $A c b$ & CTC & $S E$ & $S$ & $P$ & $\boldsymbol{E}$ \\
\hline 196837 & 7500213 & $2 \mathrm{~A}$ & Pb-Transp & 5.0 & 1.4 & 93.6 & 2.627 & - & - & 0.056 & 1.656 & 0.176 & 1.377 & - & - & - \\
\hline 196837 & 7500213 & B & Pb-Transp & 10.4 & 3.0 & 86.6 & 2.663 & - & - & 0.200 & 1.922 & 0.625 & 4.891 & - & - & - \\
\hline 196837 & 7500213 & $\mathrm{C}$ & Pb-Transp & 5.9 & 8.0 & 86.1 & 2.663 & - & - & 0.200 & 3.390 & 0.6 & 4.900 & - & - & - \\
\hline 196837 & 7500213 & $\mathrm{D}$ & Pb-Transp & 8.3 & 3.2 & 88.5 & 2.612 & - & - & 0.188 & 2.261 & 0.587 & 4.592 & - & - & - \\
\hline 196808 & 7497694 & 3 & Pb-Rsd-I & 12.1 & 7.2 & 80.7 & 2.691 & - & - & 4.569 & 37.788 & 14.282 & 111.783 & - & - & - \\
\hline 196808 & 7498235 & 5 & Pb-Transp & 13.5 & 3.2 & 83.3 & 2.699 & - & - & 0.401 & 2.974 & 1.255 & 9.822 & - & - & - \\
\hline 197914 & 7498025 & 6 & Pb-Transp & 13.9 & 2.2 & 83.9 & 2.638 & - & - & 0.376 & 2.706 & 1.176 & 9.202 & - & - & - \\
\hline 199060 & 7496382 & $7 \mathrm{~A}$ & Pb-Rsd-I & 24.6 & 3.6 & 71.8 & 2.613 & - & - & 1.817 & 7.386 & 5.679 & 44.453 & - & - & - \\
\hline 199060 & 7496382 & $7 \mathrm{~B}$ & Pb-Rsd-II & 16.8 & 4.9 & 78.3 & 2.607 & - & - & 1.713 & 10.196 & 5.354 & 41.917 & - & - & - \\
\hline 197093 & 7494328 & 8 & Pb-Rsd-II & 17.2 & 7.8 & 75.0 & 2.603 & - & - & 2.406 & 13.991 & 6.522 & 58.877 & - & - & - \\
\hline 197080 & 7494924 & 9 & Pb-Rsd-I & 4.3 & 21.7 & 75.0 & 2.602 & - & - & 3.629 & 84.399 & 11.345 & 88.793 & - & - & - \\
\hline 197485 & 7492480 & $10 \mathrm{~A}$ & Z-Aluv & 2.6 & 3.4 & 94.0 & 2.610 & - & - & 0.319 & 12.280 & 0.998 & 7.812 & - & - & - \\
\hline 197485 & 7492480 & 10B & Z-Aluv & 2.0 & 1.4 & 96.6 & 2.630 & - & - & 0.423 & 12.378 & 0.701 & 8.758 & - & - & - \\
\hline 194519 & 7504045 & 1 & Pb-Transp & 11.4 & 3.6 & 85.0 & 2.633 & - & - & 0.970 & 6.994 & 2.995 & 23.965 & - & - & - \\
\hline 194548 & 7504175 & $2 \mathrm{~A}$ & Z-Colv & 1.9 & 8.1 & 90.0 & 2.649 & - & - & 0.250 & 6.139 & 0.48 & 4.108 & - & - & - \\
\hline 194548 & 7504175 & $2 \mathrm{~B}$ & Z-Colv & 11.5 & 3.5 & 85.0 & 2.617 & - & - & 0.413 & 6.134 & 0.454 & 3.401 & - & - & - \\
\hline 194567 & 7500397 & 4 & Pb-Transp & 6.5 & 8.5 & 85.0 & 2.669 & - & - & 0.150 & 2.310 & 0.469 & 3.674 & - & - & - \\
\hline 195159 & 7497957 & $5 \mathrm{~A}$ & Pb-Transp & 8.7 & 2.7 & 88.6 & 2.608 & - & - & 0.504 & 5.787 & 1.574 & 12.319 & - & - & - \\
\hline 195153 & 7497909 & $5 B$ & Pb-Rsd-I & 27.2 & 5.1 & 67.7 & 2.653 & - & - & 2.344 & 8.617 & 7.326 & 57.344 & - & - & - \\
\hline 198564 & 7492360 & 7 & Pb-Rsd-II & 19.6 & 5.4 & 75.0 & 2.637 & - & - & 1.681 & 3.475 & 2.129 & 16.664 & - & - & - \\
\hline 196602 & 7501797 & 8 & Pb-Transp & 5.9 & 11.1 & 83.0 & 2.645 & - & - & 0.154 & 2.608 & 0.481 & 3.764 & - & - & - \\
\hline 196810 & 7502181 & 9 & Pb-Transp & 10.5 & 2.5 & 87.0 & 2.636 & - & - & 0.451 & 4.099 & 1.410 & 11.032 & - & - & - \\
\hline 196997 & 7500304 & $1 \mathrm{~A}$ & Pb-Transp & 5.0 & 1.4 & 93.6 & 2.627 & 1.532 & 0.74 & 0.056 & 1.656 & 0.176 & 1.377 & 0.64 & 51.01 & 0.5 \\
\hline 196997 & 7500304 & $2 B$ & Pb-Transp & 5.9 & 8.0 & 86.1 & 2.663 & 1.618 & 0.65 & 0.200 & 3.390 & 0.6 & 4.900 & 0.64 & 38.3 & 0.67 \\
\hline 196997 & 7500304 & $2 \mathrm{C}$ & Pb-Transp & 8.3 & 3.2 & 88.5 & 2.612 & 1.751 & 0.48 & 0.188 & 2.261 & 0.587 & 4.592 & 0.59 & 57.03 & 0.41 \\
\hline 196803 & 7497929 & 5 & Pb-Rsd-I & 12.2 & 7.6 & 80.2 & 2.689 & 1.612 & 0.67 & 4.414 & 36.180 & 13.798 & 108 & 0.29 & 9.17 & 1.26 \\
\hline
\end{tabular}




\begin{tabular}{|c|c|c|c|c|c|c|c|c|c|c|c|c|c|c|c|c|}
\hline$X$ & $Y$ & Ponto & Unidade & $\%$ Argila & \% Silte & \% Areia & $\rho s$ & $\rho d$ & $e_{0}$ & $V B$ & $A c b$ & CTC & $S E$ & $S$ & $P$ & $E$ \\
\hline 197982 & 7501759 & 8 & Pb-Transp & 6.0 & 10.8 & 83.2 & 2.630 & 1.529 & 0.72 & 0.166 & 2.758 & 0.581 & 4.049 & 0.53 & 33.38 & 0.64 \\
\hline 197041 & 7497318 & 3 & Pb-Rsd-I & 16.7 & 10.3 & 73.0 & 2.654 & 1.689 & 0.57 & 1.785 & 10.687 & 5.579 & 43.664 & 0.67 & 2.18 & 12.29 \\
\hline 197276 & 7497416 & 4 & Pb-Rsd-I & 16.0 & 9.0 & 85.0 & 2.646 & 1.686 & 0.59 & 3.980 & 24.875 & 12.441 & 97.377 & 0.24 & 6.43 & 1.49 \\
\hline 199019 & 7497761 & 9 & Pb-Transp & 16.2 & 2.5 & 81.3 & 2.635 & 1.631 & 0.71 & 0.553 & 3.410 & 1.729 & 13.530 & 1.26 & 30.37 & 1.66 \\
\hline 199118 & 7495675 & 15 & Pb-Rsd-II & 24.7 & 26.3 & 49.0 & 2.608 & 1.590 & 0.49 & 4.852 & 19.645 & 8.168 & 118.720 & 0.51 & 0.12 & 170 \\
\hline 195627 & 7495252 & $5 \mathrm{~A}$ & Pb-Rsd-I & 25.6 & 7.5 & 66.9 & 2.685 & 1.691 & 0.61 & 3.160 & 35.456 & 10.444 & 76.220 & 0.48 & 3.25 & 5.91 \\
\hline 195627 & 7495252 & $5 \mathrm{~B}$ & Pb-Rsd-II & 23.1 & 11.6 & 65.3 & 2.658 & 1.583 & 0.5 & 1.852 & 12.370 & 5.606 & 64.754 & 0.55 & 0.08 & 270.18 \\
\hline 194854 & 7506793 & 1 & SG-Rsd & 43.9 & 21.0 & 35.1 & 2.750 & 1.490 & 1.02 & 4.020 & 12.650 & 11.316 & 137.894 & 3.33 & 0.08 & 1665.00 \\
\hline 195391 & 7506181 & 2 & Itq-Rsd & 20.2 & 9.6 & 70.2 & 2.660 & 1.509 & 0.79 & 0.396 & 1.726 & 1.086 & 17.970 & 1.80 & 0.75 & 96.00 \\
\hline 195130 & 7507155 & 3 & Itq-Rsd & 30.0 & 9.0 & 61.0 & 2.604 & 1.409 & 0.85 & 0.453 & 1.511 & 1.417 & 11.093 & 1.19 & 3.21 & 14.83 \\
\hline 194301 & 7506429 & 4 & Itq-Rsd & 15.0 & 7.5 & 77.5 & 2.610 & 1.402 & 0.86 & 0.301 & 2.009 & 0.942 & 7.374 & 0.55 & 5.93 & 3.71 \\
\hline 195179 & 7497903 & 12 & Pb-Transp & 13.6 & 3.4 & 83.0 & 2.628 & 1.538 & 0.74 & 0.950 & 6.984 & 2.969 & 23.238 & 0.68 & 75.49 & 0.36 \\
\hline 195002 & 7497935 & 1 & Pb-Transp & 13.0 & 3.5 & 83.5 & 2.627 & 1.530 & 0.74 & 0.896 & 5.970 & 2.519 & 18.671 & 0.68 & 75.49 & 0.36 \\
\hline 195676 & 7495268 & $2 \mathrm{~A}$ & Pb-Rsd-I & 25.3 & 6.7 & 68.0 & 2.658 & 1.690 & 0.61 & 4.359 & 34.156 & 10.438 & 66.212 & 0.46 & 0.08 & 230.00 \\
\hline 195676 & 7495268 & $2 \mathrm{~B}$ & Pb-Rsd-II & 21.1 & 16.6 & 62.3 & 2.671 & 1.580 & 0.50 & 2.524 & 13.570 & 6.506 & 74.756 & 0.61 & 0.79 & 30.89 \\
\hline 195512 & 7494383 & $3 \mathrm{~A}$ & Pb-Transp & 8.4 & 2.5 & 89.1 & 2.672 & 1.530 & 0.64 & 0.169 & 5.671 & 0.192 & 18.671 & 0.75 & 45.96 & 0.65 \\
\hline 195512 & 7494383 & $3 \mathrm{~B}$ & Pb-Rsd-I & 20.0 & 7.7 & 72.3 & 2.630 & 1.470 & 0.60 & 3.485 & 28.241 & 7.069 & 45.817 & 0.43 & 4.40 & 3.91 \\
\hline 195512 & 7494383 & $3 \mathrm{C}$ & Pb-Rsd-I/II & 22.6 & 21.5 & 55.9 & 2.637 & 1.750 & 0.57 & 4.048 & 18.605 & 9.691 & 52.427 & 0.48 & 2.88 & 6.67 \\
\hline 197119 & 7494928 & $4 \mathrm{~A}$ & Pb-Rsd-I & 4.7 & 17.2 & 77.6 & 2.602 & 1.640 & 0.57 & 3.961 & 14.249 & 11.345 & 48.793 & 0.67 & 10.52 & 2.55 \\
\hline 197119 & 7494928 & $4 \mathrm{~B}$ & Pb-Rsd-II & 2.1 & 21.4 & 76.5 & 2.658 & 1.570 & 0.45 & 4.263 & 18.491 & 13.104 & 88.793 & 0.39 & 0.19 & 82.11 \\
\hline 195735 & 7505644 & 5 & Itq-Rsd & 21.0 & 12.0 & 59.0 & 2.610 & 1.150 & 0.92 & 0.290 & 1.290 & 0.900 & 21.002 & 0.750 & 11.80 & 2.54 \\
\hline 197147 & 7504708 & $2 \mathrm{~A}$ & SG-Transp & 36.5 & 7.5 & 56.0 & 2.804 & 1.140 & 0.89 & 0.790 & 1.215 & 2.865 & 43.183 & 0.120 & 1.02 & 4.71 \\
\hline
\end{tabular}




\begin{tabular}{|c|c|c|c|c|c|c|c|c|c|c|c|c|c|c|c|c|}
\hline$X$ & $Y$ & Ponto & Unidade & $\%$ Argila & \% Silte & \% Areia & $\rho s$ & $\rho d$ & $e_{0}$ & $V B$ & $A c b$ & CTC & $S E$ & $S$ & $P$ & $E$ \\
\hline 197147 & 7504708 & $2 B$ & SG-Transp & 49.0 & 12.5 & 38.5 & 2.791 & 1.325 & 1.42 & 0.998 & 2.522 & 4.013 & 97.250 & 0.68 & 3.22 & 8.45 \\
\hline 197147 & 7504708 & $2 \mathrm{C}$ & SG-Transp & 56.0 & 23.4 & 20.6 & 2.853 & 1.196 & 1.89 & 1.713 & 3.942 & 5.829 & 109.176 & - & - & - \\
\hline 197049 & 7504802 & 3 & Bt-Rsd & 7.0 & 6.0 & 87.0 & 2.620 & 1.497 & 0.67 & 0.199 & 2.612 & 0.659 & 4.987 & - & - & - \\
\hline 196765 & 7505463 & 5 & SG-Rsd & 28.5 & 12.5 & 59.0 & 2.842 & 1.096 & 0.98 & 1.163 & 3.012 & 7.249 & 53.110 & - & - & - \\
\hline 196472 & 7505687 & 6 & SG-Rsd & 35.0 & 18.5 & 46.5 & 2.793 & 1.213 & 1.18 & 3.562 & 5.752 & 9.098 & 98.038 & - & - & - \\
\hline 196122 & 7506326 & 10 & Itq-Rsd & 17.3 & 7.1 & 75.6 & 2.668 & 1.340 & 0.95 & 0.322 & 1.307 & 1.097 & 20.971 & 1.16 & 2.41 & 19.25 \\
\hline 197115 & 7494303 & $12 \mathrm{~A}$ & Pb-Rsd-I & 21.7 & 5.8 & 72.5 & 2.616 & - & - & 2.641 & 17.095 & 5.126 & 57.214 & - & - & - \\
\hline 197115 & 7494303 & $12 \mathrm{~B}$ & Pb-Rsd-II & 23.0 & 6.7 & 70.3 & 2.635 & - & - & 2.073 & 12.309 & 4.504 & 46.357 & - & - & - \\
\hline 198963 & 7498612 & 8 & Pb-Transp & 10.2 & 2.5 & 87.3 & 2.680 & 1.505 & 0.56 & 0.316 & 2.759 & 1.157 & 9.204 & - & - & - \\
\hline 198578 & 7495549 & 20 & Pb-Transp & 11.3 & 3.4 & 85.3 & 2.670 & 1.581 & 0.42 & 0.852 & 5.903 & 2.519 & 18.647 & - & - & - \\
\hline 197919 & 7502292 & 22 & Pb-Transp & 9.4 & 2.5 & 88.1 & 2.652 & 1.503 & 0.51 & 0.572 & 5.725 & 2.590 & 12.840 & - & - & - \\
\hline 198238 & 7492469 & 10 & Pb-Transp & 10.2 & 3.3 & 86.5 & 2.673 & - & - & 0.797 & 6.947 & 0.729 & 14.965 & - & - & - \\
\hline 195425 & 7506879 & 12 & Itq-Rsd & 22.5 & 8.3 & 69.2 & 2.672 & 0.941 & 0.99 & 0.352 & 1.171 & 1.060 & 27.1338 & 1.60 & 2.05 & 31.22 \\
\hline
\end{tabular}

Legenda
$\rho s$ - massa especifica dos sólidos; $\rho d$ - massa específica aparente seca; $\mathrm{e}_{0}$ - índice de vazios; VB - volume de azul de metileno adsorvido; Acb - índice de atividade da fração fina; CTC - capacidade de troca catiônica; SE - superfície específica; $\mathrm{S}$ - índice de absorção d'água; P - perda de peso por imersão; E - índice de erodibilidade. 